UNIVERSIDADE DE SÃO PAULO

FACULDADE DE MEDICINA DE RIBEIRÃO PRETO

DEPARTAMENTO DE FISIOLOGIA

Cahuê De Bernardis Murat

Sensibilidade à baixa glicose extracelular

em neurônios e astrócitos do núcleo do trato solitário

Ribeirão Preto

2019 
CAHUÊ DE BERNARDIS MURAT

Sensibilidade à baixa glicose extracelular em neurônios e astrócitos do núcleo do trato solitário

Versão Original

Tese apresentada à Faculdade de Medicina de Ribeirão Preto da Universidade de São Paulo para a obtenção do título de Doutor em Ciências.

Área de Concentração: Fisiologia

Orientador: Prof. Dr. Ricardo M. Leão

Ribeirão Preto 
Autorizo a reprodução e divulgação total ou parcial deste trabalho, por qualquer meio convencional ou eletrônico, para fins de estudo e pesquisa, desde que citada a fonte.

Catálogo na publicação

Serviço de Biblioteca e Documentação

Faculdade de Medicina de Ribeirão Preto

Murat, Cahuê De Bernardis Murat

Sensibilidade à baixa glicose extracelular em neurônios e astrócitos do núcleo do trato solitário / Cahuê De Bernardis Murat; orientador: Ricardo Maurício Xavier Leão. - 2019

164 f. : il.

Tese (Doutorado em Fisiologia) - Programa de Pós Graduação em Fisiologia, Faculdade de Medicina de Ribeirão Preto, Universidade de São Paulo, Ribeirão Preto, 2019

Versão original

1. Núcleo do trato solitário. 2. Glicose. 3. Hipoglicemia. 4. Neurônios. 5. Astrócitos. 6. Canais para potássio sensíveis ao ATP. 7. Inositol 1,4,5-trifosfato tipo 2. 8. Gliotransmissão. 
Nome: MURAT, Cahuê De Bernardis

Título: Sensibilidade à baixa glicose extracelular em neurônios e astrócitos do núcleo do trato solitário

Tese apresentada à Faculdade de Medicina de Ribeirão Preto da Universidade de São Paulo para a obtenção do título de Doutor em Ciências.

Aprovado em :

Banca Examinadora

Prof. Dr.

Instituição

Julgamento:

Prof. Dr.

Instituição

Julgamento:

Prof. Dr.

Instituição

Julgamento: 


\section{DEDICATÓRIA}

Dedico o presente trabalho à minha avó Léa Franco De Bernardis, por todo o amor, carinho, apoio e energia. 


\section{AGRADECIMENTOS}

Ao Prof. Ricardo M. Leão, que prontamente me recebeu em seu laboratório e me deu suporte em todas as etapas científicas durante o Doutorado. Agradeço pela confiança, liberdade e incentivo para que eu pudesse desenvolver e aprimorar os meus conhecimentos em eletrofisiologia e na ciência. Foi um imenso prazer conduzir este estudo sob sua orientação. Muito obrigado!

À Coordenação do Programa de Pós-Graduação em Fisiologia da Faculdade de Medicina de Ribeirão Preto da Universidade de São Paulo (FMRP-USP), pela oportunidade de estudar, aprender e usufruir da estrutura do Departamento.

Ao Conselho Nacional de Desenvolvimento Científico e Tecnológico (CNPq), pela concessão da bolsa de estudos e apoio financeiro durante o Doutorado na FMRP-USP.

À Coordenação de Aperfeiçoamento de Pessoal de Nível Superior (CAPES), pela concessão da bolsa de estudos e apoio financeiro durante o Doutorado no Brasil e durante o Programa de Doutorado Sanduíche no Exterior (PDSE), realizado no Departamento de Neurociências da Universidade de Minnesota (UMN), Minneapolis, MN, EUA, o qual foi uma experiência fantástica e engrandecedora em aspectos científicos, culturais e intelectuais.

Ao Prof. Alfonso Araque, que abriu as portas do seu laboratório no Departamento de Neurociências da UMN e permitiu que eu pudesse aprender sobre a atividade de cálcio em astrócitos e a sinalização astrócito-neurônio para o desenvolvimento dos meus estudos de Doutorado. Don't try, do it!

Ao Prof. Paulo Kofuji, que foi um grande colaborador durante minha passagem pela UMN, com suporte técnico e científico em experimentos eletrofisiológicos, imagens de cálcio e imunofluorescência.

Ao técnico José Fernando Aguiar, por todo 0 apoio durante 0 desenvolvimento do Doutorado na FMRP-USP. Você foi uma peça-chave para que minha tese fosse conduzida com sucesso. Certamente levarei seus aprendizados por toda minha carreira científica. Sou muito grato a ti! 
À Dra. Alexandra Siqueira Cunha, por todo o suporte durante o Doutorado, tanto em questões técnicas e profissionais como filosóficas. Obrigado por sempre me auxiliar com tamanha solicitude e motivação!

Ao Dr. André L. A. Dagostin, por não ser apenas um dos responsáveis pela minha migração ao Departamento de Fisiologia da FMRP-USP, mas também por todo o ensinamento e suporte durante a condução da minha tese. Sua paixão pela pesquisa científica é admirável, e a ciência precisa de pessoas assim!

À Dra. Daniela Accorsi Mendonça, pelo suporte técnico e científico em experimentos eletrofisiológicos no núcleo do trato solitário, além da contribuição na Banca de Qualificação de Doutorado. Agradeço também pelos ensinamentos quanto à cirurgia de marcação do corpúsculo carotídeo.

Ao Prof. Norberto Garcia Cairasco, pela sugestões e comentários relacionados à condução da minha tese. Agradeço também pelas oportunidades de integrar ciência e artes, as quais foram experiências inéditas e prazerosas.

Ao Prof. Luiz Carlos Navegantes, pela amizade e trabalhos conduzidos juntos durante o Doutorado. Obrigado pela confiança para que eu pudesse participar do PDSE nos EUA.

Ao Prof. Vander Baptista, que foi o grande responsável por me apresentar a eletrofisiologia. Ter visto a felicidade que o senhor sente ao falar de patch-clamp foi um dos maiores impulsos para eu focar minha carreira nesta área.

Aos membros do Laboratório de Neurofisiologia e Sinapse do Departamento de Fisiologia da FMRP-USP, pelo aprendizado em eletrofisiologia, suporte técnico e científico, e confraternizações ao longo do Doutorado.

Aos membros do laboratório dirigido pelo Prof. Alfonso Araque no Departamento de Neurociências da UMN, pela recepção, convivência, ensinamentos, e alegrias ao longo da minha estadia em Minneapolis.

Aos colegas e amigos do Departamento de Fisiologia da FMRP-USP, pelas boas conversas científicas, momentos descontraídos e confraternizações. 
Às secretárias do Departamento de Fisiologia da FMRP-USP Elisa Maria Aleixo e Cláudia de Barcelos Vanzela, por todo o suporte administrativo durante o Doutorado.

Aos moradores, ex-moradores e agregados da República Tosca, que possibilitaram que meu Doutorado fosse conduzido sob uma atmosfera incrivel!

À minha família, pelo amor, carinho e apoio imensuráveis durante toda a minha vida. Eternamente grato!

A todos que de alguma forma contribuíram para que este trabalho pudesse ser concluído. 
"Quem navega no mar sempre encontra um lugar pra ficar." (Rogério Cavalcanti) 


\section{RESUMO}

MURAT, Cahuê De Bernardis. Sensibilidade à baixa glicose extracelular em neurônios e astrócitos do núcleo do trato solitário. 2019. 164 f. Tese (Doutorado em Fisiologia) - Faculdade de Medicina de Ribeirão Preto, Universidade de São Paulo, Ribeirão Preto, 2019.

O cérebro é altamente dependente da glicose para manter o metabolismo celular, e a hipoglicemia cerebral pode comprometer a neurotransmissão e sobrevivência. $O$ núcleo do trato solitário (NTS) é um centro integrativo para o controle da glicemia, e recentes estudos mostram que neurônios e astrócitos do NTS podem responder a alterações da concentração de glicose no ambiente extracelular. No presente estudo, visamos investigar os mecanismos de sensibilidade à baixa glicose extracelular em neurônios e astrócitos do NTS em fatias do tronco encefálico de roedores. Em condições normoglicêmicas, verificamos que a maioria dos neurônios do NTS despolarizam em resposta à baixa glicose extracelular por um mecanismo dependente de voltagem que envolve a abertura de uma corrente catiônica. Adicionalmente, demonstramos que os canais para potássio sensíveis ao ATP ( $\left.\mathrm{K}_{\text {ATP }}\right)$ controlam o potencial de repouso da membrana, e portanto são moduladores significativos da sensibilidade à baixa glicose extracelular em neurônios do NTS. Em astrócitos do NTS, observamos que a diminuição da concentração de glicose extracelular aumenta a frequência de oscilações de cálcio citosólico por um mecanismo dependente da mobilização de cálcio mediada pelo receptor de inositol 1,4,5-trifosfato tipo $2\left(I_{3} R 2\right)$ em retículos endoplasmáticos. Verificamos também a existência de sinalização astrócito-neurônio por glutamato, a qual pode ser regulada pela concentração de glicose do meio externo. Além disso, demonstramos que uma condição hiperglicêmica compromete a sensibilidade à baixa glicose extracelular em neurônios e astrócitos do NTS, e pode afetar a gliotransmissão. Nossos dados sugerem que a sensibilidade à baixa glicose extracelular em neurônios e astrócitos do NTS pode estar relacionada à deficiência autonômica associada à hipoglicemia.

Palavras-chave: Núcleo do trato solitário. Glicose. Hipoglicemia. Neurônios. Astrócitos. Canais para potássio sensíveis ao ATP. Inositol 1,4,5-trifosfato tipo 2. Gliotransmissão. 


\begin{abstract}
MURAT, C. D. B. Low-glucose sensing in neurons and astrocytes from the nucleus of the tractus solitarius. 2019. 164 p. Thesis (PhD Degree in Physiology) School of Medicine of Ribeirão Preto, University of São Paulo, Ribeirão Preto, 2019.
\end{abstract}

The brain primarily relies on glucose for sustaining cell metabolism, and brain hypoglycemia may compromise neurotransmission and cell survivor. The nucleus tractus solitarius (NTS) is an integrative center for the control of circulating glucose, and recent studies have shown that NTS neurons and astrocytes can respond to glucose concentration changes in the extracellular milieu. Here, we aimed to investigate the low-glucose-sensing mechanisms in NTS neurons and astrocytes from rodent brainstem slices. In normoglycemic conditions (5 mM glucose), we verified that most NTS neurons depolarize in response to a low-glucose challenge (0.5 mM glucose), in a voltage-dependent mechanism involving the opening of a cationic current. Additionally, we demonstrated that ATP-sensitive potassium channels ( $\mathrm{K}_{\mathrm{ATP}}$ ) control the resting membrane potential, thus notably modulating the low-glucose response in neurons. Regarding the NTS astrocytes, we observed that the reduction of external glucose concentration induces an increase in calcium oscillation frequency in the soma via an inositol 1,4,5-triphosphate type 2 (IP ${ }_{3}$ R2)dependent calcium release from the endoplasmic reticulum. We also verified the existence of a glutamate-mediated astrocyte-neuron signaling that can be regulated by extracellular glucose levels. Moreover, we showed that a hyperglycemic condition (10 mM glucose) compromises the low-glucose sensitivity in NTS neurons and astrocytes, and can affect gliotransmission. Our data suggest that the low-glucose sensing mechanisms might be related to the hypoglycemia-associated autonomic failure.

Keywords: Nucleus tractus solitarius. Glucose. Hypoglycemia. Neurons. Astrocytes. ATP-sensitive potassium channels. Inositol 1,4,5-triphosphate type 2. 


\section{LISTA DE FIGURAS}

Figura 1. 0 papel integrativo do núcleo do trato solitário na regulação neural da homeostase da glicose. Flutuações de glicose extracelular ativam glicossensores neuronais periféricos, os quais projetam-se para o núcleo do trato solitário (NTS). Alterações da concentração de glicose também podem regular a excitabilidade de neurônios do NTS, bem como neurônios hipotalâmicos. Adicionalmente, neurônios do NTS integram sinais com áreas corticolímbicas, e principalmente projetam-se ao núcleo motor dorsal do vago (DMNX) para regular respostas autonômicas à hipoglicemia. Adaptado de Marty et al. (2007).

Figura 2. Confirmação da deleção knockout do gene $\mathrm{Ip}_{3} \mathrm{r} 2$ em camundongos transgênicos. Montagens de uma fotografia de um gel representativo da genotipagem de animais transgênicos Cre-Ip ${ }_{3}$ r2. A amostra do DNA obtido do animal número 3 possui a banda representativa do gene Cre $(\mathrm{C}+$, à esquerda) e não possui a banda representativa do gene $\mathrm{Ip}_{3} \mathrm{r} 2$ [KO (knockout), à direita], o que confirma a construção transgênica knockout para o gene $\mathrm{Ip}_{3} \mathrm{r} 2$ neste camundongo, sendo então selecionado para o estudo. Note a genotipagem de camundongos heterozigóticos (números 1 e 2 ; +/-) e selvagem [número 4; WT (wild-type)]. C-, controle negativo; $\mathrm{C}+$, controle positivo.

Figura 3. Identificação de neurônios do NTS. A, fotomicrografia representativa de uma fatia do tronco encefálico de rato sob óptica DIC mostra o posicionamento da pipeta de registro (PR) durante um experimento em whole-cell patch-clamp em um neurônio do NTS. A amplificação da imagem detalha o neurônio em registro. $\mathbf{B}$, desenho esquemático da imagem mostrada em $\mathbf{A}$ indica a localização do NTS e áreas adjacentes [adaptado de Barraco et al. (1992)]. C, alterações de voltagem induzidas por injeção de correntes deflagram o disparo elétrico característico de neurônios do NTS. 10, núcleo do nervo hipoglosso; 12, núcleo motor dorsal do vago; $\mathrm{AP}$, área postrema; $\mathrm{c}$, canal central; ts, trato solitário.

Figura 4. Populações distintas de neurônios do NTS em relação à resposta despolarizante induzida pela baixa glicose extracelular. Em ambas condições normo- e hiperglicêmica, a análise da amplitude da alteração do 
potencial de membrana $\left(V_{m}\right)$ em resposta à baixa glicose em neurônios mostra a existência de duas populações distintas: uma cujo potencial de membrana varia até $3 \mathrm{mV}$, a outra que varia acima de $4 \mathrm{mV}$. aCSF, solução cerebroespinal artificial.

Figura 5. Gliotransmissão mediada por glutamato. O aumento da concentração de cálcio citosólico induzido por um estímulo em astrócitos leva à liberação de glutamato no espaço intersticial. Estes gliotransmissores agem em receptores NMDA (NMDAR) extrassinápticos localizados em neurônios adjacentes, gerando uma corrente de entrada com cinéticas lentas (SICs) em comparação às correntes pós-sinápticas excitatórias (EPSC). Desenho esquemático baseado em Fellin et al. (2004) e Navarrete \& Araque (2008), e registros eletrofisiológicos extraídos de Durkee et al. (2019).

Figura 6. Identificação de astrócitos do NTS por microscopia de fluorescência. As imagens representativas mostram o sinal obtido do marcador de astrócitos sulforodamina (SR101; à esquerda) e do indicador de cálcio Fluo-4-AM (ao centro). À direita, a sobreposição das duas primeiras imagens mostra astrócitos que captaram Fluo-4-AM, sendo estão selecionados para a análise de oscilações de cálcio (indicados pela setas). Note a alta seletividade de captação de Fluo-4-AM por astrócitos.

Figura 7. Identificação dos astrócitos do NTS por propriedades eletrofisiológicas. A, alterações de voltagem a passos de injeção de correntes em um astrócito representativo não geram atividade elétrica. $\mathbf{B}$, alterações de corrente a passos de voltagem no mesmo astrócito evidenciam a ausência de canais de sódio dependentes de voltagem (à esquerda), o que resulta em uma relação corrente-voltagem linear característica de astrócitos (à direita). 35

Figura 8. Design experimental para o estudo da gliotransmissão no NTS. A, sob microscopia epifluorescente, realizamos o monitoramento dos sinais de cálcio em astrócitos simultaneamente ao registro em whole-cell patch-clamp em neurônios adjacentes, com o intuito de correlacionar as oscilações de cálcio citosólico em astrócitos com a geração de correntes de entrada lentas (SICs) em neurônios vizinhos. B, o delineamento experimental consistiu no registro eletrofisiológico em neurônio do NTS em condições normoglicêmicas (aCSF 
contendo $5 \mathrm{mM}$ de glicose) por cinco minutos, com as imagens de cálcio iniciadas nos dois últimos minutos nestas condições. Então, a fatia foi perfundida com uma solução aCSF contendo baixa glicose $(0,5 \mathrm{mM})$, e o efeito avaliado por cinco minutos adicionais em neurônios e astrócitos simultaneamente. Todos os experimentos foram conduzidos na presença de tetrodotoxina $(0,5 \mu \mathrm{M})$. Registros eletrofisiológicos extraídos de Durkee et al. (2009).

Figura 9. Identificação de astrócitos do NTS em camundongos GFAP-GCaMP6. As imagens representativas mostram o sinal obtido do marcador de astrócitos sulforodamina (SR101; à esquerda) e do indicador de cálcio GCaMP6 (ao centro). À direita, a sobreposição das duas primeiras imagens confirma a seletividade das imagens de cálcio em astrócitos (indicado pelas setas). Note que pés-terminais de astrócitos envolvem um vaso sanguíneo. Escala horizontal: $20 \mu \mathrm{m}$.

Figura 10. Grupo de neurônios do NTS responsivos à tolbutamida. A, registro representativo de um neurônio responsivo à tolbutamida. B, resumo do efeito da tolbutamida no potencial de membrana $\left(V_{m}\right)$ em neurônios responsivos. C, resumo do efeito da tolbutamida na frequência de potenciais de ação em neurônios responsivos. Tolb, tolbutamida. ${ }^{* *} p<0,01 ;{ }^{* * *} p<0,0001$.

Figura 11. Grupo de neurônios do NTS não-responsivos à tolbutamida. A, registro representativo de um neurônio não-responsivo à tolbutamida. $\mathbf{B}$, resumo do efeito da tolbutamida no potencial de membrana $\left(V_{m}\right)$ em neurônios nãoresponsivos. C, resumo do efeito da tolbutamida na frequência de potenciais de ação em neurônios não-responsivos. Tolb, tolbutamida.

Figura 12. A despolarização induzida pelo fechamento dos canais $K_{A T P}$ é dependente do potencial de repouso da membrana em neurônios do NTS. A, comparação do potencial de repouso da membrana (RMP) entre neurônios responsivos $(R)$ e não-responsivos $(N R)$ à tolbutamida. $B$, correlação linear entre a alteração do potencial de membrana $\left(V_{m}\right)$ induzida pela tolbutamida e o RMP em neurônios. * $p<0,05$. 44

Figura 13. Grupo de neurônios do NTS responsivos à tolbutamida na presença de tetrodotoxina. A, registro representativo de um neurônio responsivo à 
tolbutamida na presença de tetrodotoxina (TTX). B, resumo do efeito da tolbutamida no potencial de membrana $\left(V_{m}\right)$ em neurônios responsivos. C, resumo do efeito da tolbutamida na resistência de entrada da membrana ( $\left.R_{\text {input }}\right)$ em neurônios responsivos. Tolb, tolbutamida. ${ }^{* \star *} p<0,001$.

Figura 14. Grupo de neurônios do NTS não-responsivos à tolbutamida na presença de tetrodotoxina. A, registro representativo de um neurônio nãoresponsivo à tolbutamida na presença de tetrodotoxina (TTX). B, resumo do efeito da tolbutamida no potencial de membrana $\left(V_{m}\right)$ em neurônios nãoresponsivos. C, resumo do efeito da tolbutamida na resistência de entrada da membrana $\left(R_{\text {input }}\right)$ em neurônios não-responsivos. Tolb, tolbutamida. 46

Figura 15. Neurônios do NTS possuem canais $K_{\text {ATP }}$ ativos no repouso. A, comparação do potencial de repouso da membrana (RMP) entre neurônios responsivos $(R)$ e não-responsivos $(N R)$ à tolbutamida. $B$, correlação linear entre a alteração do potencial de membrana $\left(V_{m}\right)$ induzida pela tolbutamida e o RMP em neurônios. C, correlação linear entre a alteração da resistência de entrada da membrana $\left(R_{\text {input }}\right)$ induzida pela tolbutamida e a $R_{\text {input }}$ basal em neurônios. ${ }^{*} p<0,05$.

Figura 16. A modulação dos canais $K_{A T P}$ afeta o potencial de repouso da membrana em neurônios do NTS. A, registro representativo do efeito da aplicação de diazoxida em um neurônio na presença de tetrodotoxina (TTX). B, resumo do efeito da diazoxida no potencial de membrana $\left(V_{m}\right)$ em neurônios. $C$, resumo do efeito da diazoxida na resistência de entrada da membrana ( $\left.R_{\text {input }}\right)$ em neurônios. $D Z$, diazoxida. ${ }^{*} p<0,05 ;{ }^{* *} p<0,01$.

Figura 17. Os canais $K_{A T P}$ controlam o potencial de repouso da membrana em neurônios do NTS. A, correlação linear entre a alteração do potencial de membrana $\left(V_{m}\right)$ induzida pela diazoxida e o potencial de repouso da membrana (RMP) em neurônios. B, correlação linear entre a alteração da resistência de entrada da membrana $\left(R_{\text {input }}\right)$ induzida pela diazoxida e a $R_{\text {input }}$ basal em neurônios. 49

Figura 18. Grupo de neurônios do NTS responsivos à baixa glicose extracelular. A, registro representativo de um neurônio responsivo à baixa 
glicose. B, resumo do efeito da baixa glicose no potencial de membrana $\left(V_{m}\right)$ em neurônios responsivos. ${ }^{* * *} p<0,0001$.

Figura 19. Grupo de neurônios do NTS não-responsivos à baixa glicose extracelular. $\mathbf{A}$, registro representativo de um neurônio não-responsivo à baixa glicose. B, resumo do efeito da baixa glicose no potencial de membrana $\left(V_{m}\right)$ em neurônios

Figura 20. Grupo de neurônios do NTS responsivos à baixa glicose extracelular na presença de tetrodotoxina. A, registro representativo de um neurônio responsivo à baixa glicose na presença de tetrodotoxina (TTX). B, resumo do efeito da baixa glicose no potencial de membrana $\left(V_{m}\right)$ em neurônios. C, resumo do efeito da baixa glicose na resistência de entrada da membrana ( $\left.R_{\text {input }}\right)$ em neurônios. ${ }^{*} p<0,05 ;{ }^{* * *} p<0,0001$.

Figura 21. Grupo de neurônios do NTS não-responsivos à baixa glicose extracelular na presença de tetrodotoxina. A, registro representativo de um neurônio não-responsivo à baixa glicose na presença de tetrodotoxina (TTX). B, resumo do efeito da baixa glicose no potencial de membrana $\left(V_{m}\right)$ em neurônios. C, resumo do efeito da baixa glicose na resistência de entrada da membrana $\left(R_{\text {input }}\right)$ em neurônios. ${ }^{* * *} p<0,001$

Figura 22. A baixa glicose extracelular induz um mecanismo de resposta dependente de voltagem em neurônios do NTS. A, correlação linear entre a alteração do potencial de membrana $\left(V_{m}\right)$ induzida pela baixa glicose e o potencial de repouso da membrana (RMP) em neurônios. B, correlação linear entre as alterações de $V_{m}$ e resistência de entrada da membrana ( $\left.R_{\text {input }}\right)$ induzidas pela baixa glicose em neurônios. C, comparação do RMP entre neurônios responsivos (R) e não-responsivos (NR) à baixa glicose. ${ }^{* * *} p<0,001$.

Figura 23. A presença de glicose na pipeta de registro inibe a detecção da baixa glicose extracelular por neurônios do NTS. A, resumo do efeito da baixa glicose no potencial de membrana $\left(V_{m}\right)$ em neurônios registrados com solução de pipeta contendo $3 \mathrm{mM}$ de glicose. B, comparação do potencial de repouso da membrana (RMP) entre neurônios registrados com solução de pipeta normal e solução de pipeta contendo $3 \mathrm{mM}$ de glicose. C, comparação do 
RMP entre neurônios não-responsivos à baixa glicose registrados com solução de pipeta normal e neurônios registrados com solução de pipeta contendo $3 \mathrm{mM}$ de glicose. ${ }^{*} p<0,05$.

Figura 24. Influência da idade na alteração do potencial de membrana induzida pela baixa glicose extracelular em neurônios do NTS. A, resumo do efeito induzido pela baixa glicose no potencial de membrana $\left(V_{m}\right)$ em neurônios responsivos (Ai) e não-responsivos (Aii) de animais com 3 semanas de idade. B, resumo do efeito induzido pela baixa glicose no $V_{m}$ em neurônios responsivos (Bi) e não-responsivos (Bii) de animais com 6 semanas de idade. $\mathbf{C}$, resumo do efeito induzido pela baixa glicose no $V_{m}$ em neurônios responsivos $(\mathbf{C} i)$ e nãoresponsivos (Cii) de animais com 11 semanas de idade. Em todas as figuras, os pontos e traçados pretos indicam neurônios registrados com solução aCSF, enquanto os pontos e traçados cinzas indicam neurônios registrados com solução aCSF na presença de tetrodotoxina. ${ }^{*} p<0,05$; ${ }^{* * *} p<0,001$; ${ }^{* \star * *} p<$ 0,0001 . 59

Figura 25. Animais na fase adulta apresentam menor proporção de neurônios do NTS sensíveis à baixa glicose extracelular em comparação a animais mais jovens. A, comparação do potencial de repouso da membrana (RMP) entre neurônios de animais com 3, 6 e 11 semanas de idade. B, comparação da alteração do potencial de membrana $\left(V_{m}\right)$ induzida pela baixa glicose entre neurônios de animais com 3, 6 e 11 semanas de idade. C, comparação da distribuição dos neurônios de acordo com a resposta induzida pela baixa glicose em animais com 3,6 e 11 semanas de idade. ${ }^{*} p<0,05 ;{ }^{* *} p<0,01$.

Figura 26. Influência da idade no efeito da tolbutamida em neurônios do NTS. A, resumo do efeito induzido pela tolbutamida no potencial de membrana $\left(V_{m}\right)$ em neurônios responsivos ( $\mathbf{A} i)$ e não-responsivos $(\mathbf{A} i i)$ de animais com 3 semanas de idade. $B$, resumo do efeito induzido pela tolbutamida no $V_{m}$ em neurônios responsivos (Bi) e não-responsivos (Bii) de animais com 11 semanas de idade. Tolb, tolbutamida. ${ }^{* * *} \mathrm{p}<0,0001$

Figura 27. Influência da idade no potencial de repouso da membrana e resposta à tolbutamida. A, comparação da alteração do potencial de membrana $\left(V_{m}\right)$ induzido pela tolbutamida entre neurônios de animais com 3 e 
11 semanas de idade. $\mathbf{B}$, comparação do potencial de repouso da membrana (RMP) entre neurônios responsivos e não-responsivos à tolbutamida de com $3 \mathrm{e}$ 11 semanas de idade. C, comparação da distribuição dos neurônios de acordo com a resposta induzida pela tolbutamida em animais com 3 e 11 semanas de idade. ${ }^{*} p<0,05$.

Figura 28. A despolarização induzida pela baixa glicose extracelular é gerada por uma condutância de entrada em neurônios do NTS. A, registros representativos das correntes geradas em resposta a passos de voltagem, obtidas em condição basal (5 mM de glicose; preto) e em baixa glicose $(0,5 \mathrm{mM}$; vermelho), e a respectiva subtração das correntes (azul). B, regressão linear da relação corrente-voltagem de neurônios registrados nas condições descritas em A. 65

Figura 29. A oclusão dos canais $K_{A T P}$ impede a despolarização induzida pela baixa glicose extracelular em neurônios do NTS. A, registro representativo de um neurônio responsivo à baixa glicose mostra que a aplicação de tolbutamida inibe este efeito despolarizante. B, neurônios responsivos à baixa glicose também são despolarizados pela tolbutamida, mas este efeito oclui a sensibilidade à baixa glicose. C, comparação da amplitude de despolarização induzida pela baixa glicose antes e depois da aplicação de tolbutamida em neurônios mostrada em B. Tolb, tolbutamida; TTX, tetrodotoxina. ${ }^{*} p<0,05$; ${ }^{* *} p$ $<0,01$.

Figura 30. A hiperpolarização do potencial de membrana permite que a baixa glicose extracelular despolarize neurônios do NTS. A, resumo dos efeitos da baixa glicose e tolbutamida no potencial de membrana $\left(V_{m}\right)$ em neurônios responsivos. B, comparação da amplitude de resposta à baixa glicose antes e depois da aplicação de tolbutamida em neurônios mostrada em $\mathbf{A}$. $\mathbf{H}$, potencial de membrana hiperpolarizado; Tolb, tolbutamida; TTX, tetrodotoxina. ${ }^{*} p<0,05$; ${ }^{* *} p<0,01$

Figura 31. Neurônios do NTS não-responsivos à baixa glicose extracelular também não respondem à aplicação de tolbutamida. A, resumo do efeito da aplicação de tolbutamida no potencial de membrana $\left(V_{m}\right)$ em neurônios nãoresponsivos à baixa glicose. B, comparação do potencial de repouso da 
membrana (RMP) entre neurônios responsivos $(R)$ e não-responsivos (NR) à baixa glicose e tolbutamida. Tolb, tolbutamida. ${ }^{*} p<0,05$.

Figura 32. A incubação em solução hiperglicêmica diminui o número de neurônios do NTS sensíveis à baixa glicose extracelular. A, comparação do potencial de repouso da membrana (RMP) entre neurônios incubados em solução normo- (5 mM de glicose) e hiperglicêmica (10 mM de glicose). B, resumo do efeito da baixa glicose e tolbutamida no potencial de membrana $\left(V_{m}\right)$ em neurônios responsivos em condição hiperglicêmica. C, comparação da distribuição dos neurônios incubados em solução de 5 e 10 mM de glicose, de acordo com a resposta induzida pela baixa glicose. Tolb, tolbutamida. ${ }^{*} p<0,05$; ${ }^{* *} p<0,01$

Figura 33. A incubação em solução hiperglicêmica despolariza o potencial de repouso da membrana e resulta em maior número de neurônios do NTS não-responsivos à baixa glicose extracelular. A, comparação do potencial de repouso da membrana (RMP) entre neurônios responsivos (R) e nãoresponsivos (NR) à baixa glicose em condição hiperglicêmica. B, resumo dos efeitos da baixa glicose e tolbutamida no potencial de membrana $\left(V_{m}\right)$ em neurônios não-responsivos em condição hiperglicêmica. C, correlação linear entre a alteração do $V_{m}$ induzida pela baixa glicose e o RMP em neurônios em condição hiperglicêmica. Tolb, tolbutamida. * $p<0,05$.

Figura 34. A hiperpolarização de neurônios do NTS em solução hiperglicêmica não recupera a resposta à baixa glicose extracelular e à aplicação de tolbutamida. A, neurônios incubados em solução hiperglicêmica que estavam em potencial de repouso da membrana (RMP) mais positivo foram hiperpolarizados, e então expostos à baixa glicose e à tolbutamida. B, comparação da alteração do potencial de membrana $\left(V_{m}\right)$ induzida pela baixa glicose entre neurônios responsivos incubados em solução hiperglicêmica e neurônios hiperpolarizados mostrados em A. C, comparação da alteração do $V_{m}$ induzida por tolbutamida entre neurônios incubados em solução normoglicêmica e neurônios mostrados em A. Hiperpol; neurônios hiperpolarizados em condição hiperglicêmica; Resp, neurônios responsivos em condição normoglicêmica; Tolb, tolbutamida. ${ }^{*} p<0,05 ;{ }^{* *} p<0,01 ;{ }^{* * *} p<0,001$ 
Figura 35. A despolarização do potencial de membrana gerada por uma longa exposição à baixa glicose extracelular é revertida pela abertura dos canais $\mathrm{K}_{\mathrm{ATP}}$ em neurônios do NTS. Grupo de neurônios despolarizados pela baixa glicose apresenta hiperpolarização após um longo período de exposição (B), como demonstrado no registro representativo em $\mathbf{A}$. Note que a tolbutamida reverte o efeito hiperpolarizante induzido pela baixa glicose. Tolb, tolbutamida; TTX, tetrodotoxina; $V_{m}$, potencial de membrana. * $p<0,05$. 75

Figura 36. Neurônio não-responsivo à baixa glicose extracelular são hiperpolarizados após um longo período de exposição à baixa glicose. Registro representativo de um neurônio não-responsivo à baixa glicose mostra a hiperpolarização causada pela longa exposição à baixa glicose. TTX, tetrodotoxina; $\mathrm{V}_{\mathrm{m}}$, potencial de membrana. 75

Figura 37. O fechamento dos canais $\mathrm{K}_{\text {ATP }}$ é suficiente para inibir a hiperpolarização induzida por uma longa exposição à baixa glicose extracelular em neurônios do NTS. A aplicação de tolbutamida inibe o efeito hiperpolarizante induzido por um longo período de exposição à baixa glicose em neurônios (B), como demonstrado no registro eletrofisiológico representativo em A. Tolb, tolbutamida; TTX, tetrodotoxina; $V_{m}$, potencial de membrana. 76

Figura 38. Oscilações espontâneas de cálcio em astrócitos do NTS. A, imagens representativas mostram astrócitos do NTS durante um experimento utilizando imagens de cálcio por meio do indicador Fluo-4-AM. À esquerda, micrografia obtida por óptica DIC. À direita, imagem em z-stack obtida pela excitação de Fluo-4-AM sob microscopia epifluorescente. Escala horizontal: $15 \mu \mathrm{m}$. B, as imagens demonstram a intensidade do sinal emitido por Fluo-4-AM durante uma oscilação espontânea de cálcio nos astrócitos indicados em A. Escala horizontal: $8 \mu \mathrm{m}$.

Figura 39. A baixa glicose extracelular ativa astrócitos do NTS por um mecanismo dependente de $I_{3}$ R2. $\mathbf{A}$, imagem representativa em pseudocor demonstra a intensidade do sinal emitido pelo indicador de cálcio Fluo-4-AM obtidas por microscopia epifluorescente em astrócitos. Em destaque à direita, um astrócito silente em condição basal ( $5 \mathrm{mM}$ de glicose; acima) e ativado em baixa glicose $(0,5 \mathrm{mM}$; abaixo $)$. $\mathbf{B}$, traçados representativos mostram a 
intensidade da fluorescência $\left(\Delta \mathrm{F} / \mathrm{F}_{0}\right)$ adquirida no soma de astrócitos durante o desafio da baixa glicose. C, número de oscilações de cálcio citosólico em astrócitos expostos à baixa glicose em animais controle (azul) e $\mathrm{IP}_{3} \mathrm{R} 2^{-1-}$ (vermelho). D, comparação da frequência das oscilações de cálcio citosólico em astrócitos em condição normoglicêmica e quando expostos à baixa glicose, em animais controle e $\mathrm{IP}_{3} \mathrm{R} 2^{-/}$. E, comparação da porcentagem de astrócitos ativos em condição basal e em resposta à baixa glicose, em animais controle e $\mathrm{IP}_{3} \mathrm{R} 2^{-1}$. F, comparação da distribuição dos astrócitos de acordo com a alteração da frequência de oscilações de cálcio induzida pela baixa glicose, em animais controle e $\mathrm{IP}_{3} \mathrm{R} 2^{-/}$. ${ }^{*} \mathrm{p}<0,05 ;{ }^{* *} \mathrm{p}<0,01 ;{ }^{* * * *} \mathrm{p}<0,0001$.

Figura 40. A gliotransmissão glutamatérgica presente no NTS pode ser regulada pela baixa glicose extracelular. $\mathbf{A}$, comparação das cinéticas de ativação e inativação entre uma corrente de entrada lenta (SIC; em azul) e uma minicorrentes excitatórias pós sinápticas (mEPSC; em preto). B, número de SICs registrados em neurônios expostos à baixa glicose. C, comparação da frequência de SICs neuronais em condição normoglicêmica e quando expostos à baixa glicose, em animais controle e $I_{3} R 2^{-/}$, e na presença de DLAP5. $D$, comparação da distribuição dos neurônios de acordo com a alteração da frequência das SICs induzida pela baixa glicose, em animais controle e $\mathrm{IP}_{3} \mathrm{R} 2^{-/}$.

Figura 41. Influência de uma condição hiperglicêmica na sensibilidade à baixa glicose extracelular em astrócitos do NTS. A, traçados representativos mostram a intensidade da fluorescência $\left(\Delta \mathrm{F} / \mathrm{F}_{0}\right)$ adquirida no soma de astrócitos incubados em $10 \mathrm{mM}$ de glicose durante o desafio da baixa glicose. $\mathbf{B}$, número de oscilações de cálcio citosólico em astrócitos incubados em condição hiperglicêmica quando expostos à baixa glicose. C, comparação da frequência das oscilações de cálcio citosólico em resposta à baixa glicose em astrócitos. $\mathbf{D}$, comparação da porcentagem de astrócitos ativos em condição basal e em resposta à baixa glicose.

Figura 42. Comparação do efeito da baixa glicose extracelular entre astrócitos do NTS incubados em 5 ou $10 \mathrm{mM}$ de glicose. A, comparação da porcentagem de astrócitos espontaneamente ativos incubados em 5 ou $10 \mathrm{mM}$ de glicose. B, comparação da frequência de oscilações basais de cálcio 
citosólico entre astrócitos incubados em 5 ou $10 \mathrm{mM}$ de glicose. C, comparação da distribuição dos neurônios de acordo com a alteração da frequência de oscilações de cálcio induzida pela baixa glicose. ${ }^{* * * *} p<0,0001$. 85

Figura 43. A gliotransmissão glutamatérgica presente no NTS pode ser modulada por alterações da glicose extracelular. A, número de correntes de entrada lentas (SICs) registrados em neurônios incubados em condição hiperglicêmica (10 mM de glicose) em resposta à baixa glicose. B, comparação da frequência de SICs em condição basal e quando expostos à baixa glicose. C, comparação da frequência basal de SIC entre neurônios incubados em 5 e 10 $\mathrm{mM}$ de glicose. D, comparação da distribuição dos neurônios de acordo com a alteração da frequência das SICs induzida pela baixa glicose.

Figura 44. Seletividade da expressão de GCaMP6 em astrócitos do NTS. As imagens representativas obtidas por imunofluorescência mostram a colocalização (à direita) de astrócitos (GFAP) com o indicador de cálcio GCaMP6. Note que neurônios (NeuN) não exibem colocalização com GCaMP6.

Figura 45. Astrócitos do NTS exibem atividade espontânea de cálcio no soma e processos. As imagens representativas em pseudocor mostram uma oscilação espontânea de cálcio no soma e processos de dois astrócitos sob microscopia multifóton. Os sinais de cálcio foram obtidos em astrócitos de camundongos geneticamente modificados que expressam o indicador de cálcio GCaMP6. Escala horizontal: $10 \mu \mathrm{m}$. 88

Figura 46. Mecanismo de resposta à baixa glicose extracelular em neurônios do NTS a partir de uma condição normoglicêmica. Em condição normoglicêmica, os canais $\mathrm{K}_{\mathrm{ATP}}$ estão parcialmente abertos na membrana plasmática de neurônios devido à razão ATP/ADP citosólica, o que estabelece um potencial de repouso da membrana (RMP) mais hiperpolarizado. Deste modo, a baixa glicose extracelular induz a abertura de uma corrente cationica por um mecanismo depende de voltagem, o que despolariza o potencial de membrana e gera atividade elétrica no neurônio.

Figura 47. Uma condição hiperglicêmica abole a resposta à baixa glicose extracelular em neurônios do NTS. Em uma condição hiperglicêmica, a alta 
razão ATP/ADP citosólica induz o fechamento de canais $\mathrm{K}_{\mathrm{ATP}}$, o que estabelece o potencial de repouso da membrana (RMP) de neurônios em um valor mais despolarizado. Deste modo, a despolarização dependente de voltagem desencadeada pela baixa glicose extracelular não é observada, o que leva ao aumento do número de neurônios não-responsivos à diminuição da concentração de glicose externa........................................................... 92 
1. INTRODUÇÃO

1.1. Glicose: substrato energético essencial ao cérebro............................ 15

1.2. O núcleo do trato solitário na regulação da homeostase da glicose .... 16

1.3. Neurônios sensíveis à glicose no núcleo do trato solitário ................... 18

1.3.1. Canais para potássio sensíveis ao ATP ......................................... 20

1.4. Astrócitos na regulação da homeostase da glicose ............................. 21

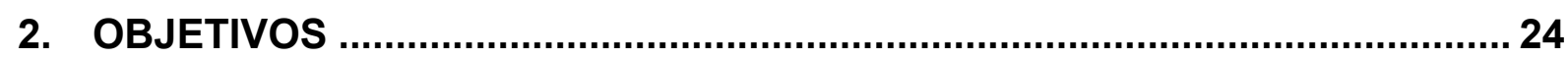

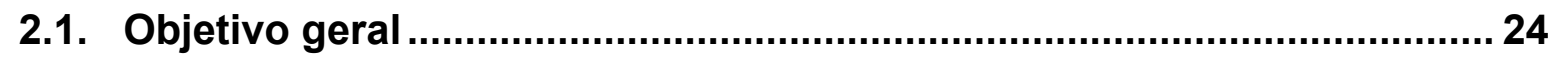

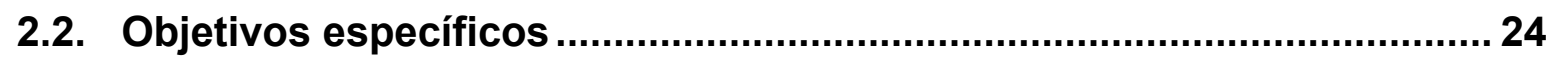

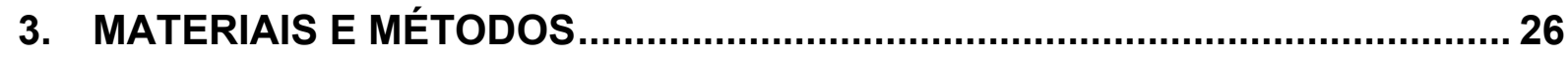

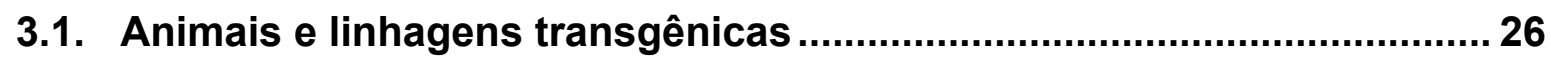

3.2. Preparação das fatias do tronco encefálico.......................................... 28

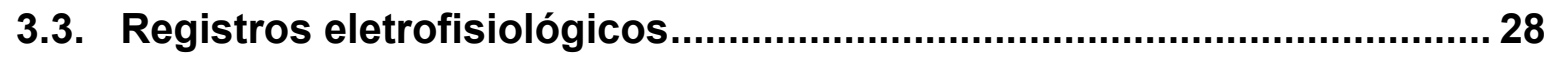

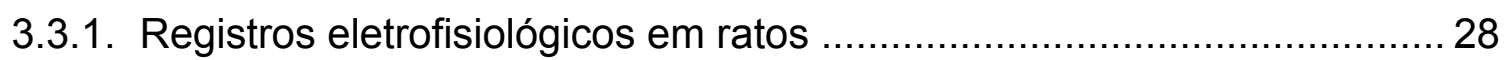

3.3.2. Registros eletrofisiológicos em camundongos ..................................... 31

3.4. Marcação e identificação dos astrócitos do NTS ...................................... 34

3.5. Imagem de cálcio em astrócitos do NTS ……......................................... 35

3.5.1. Imagem de cálcio por microscopia epifluorescente .............................. 35

3.5.2. Imagem de cálcio por microscopia multifóton ..................................... 38

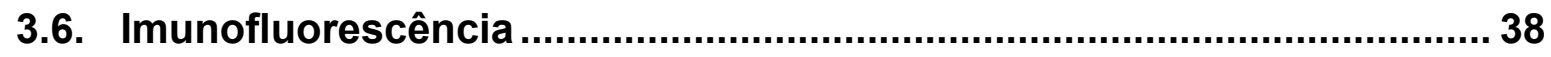

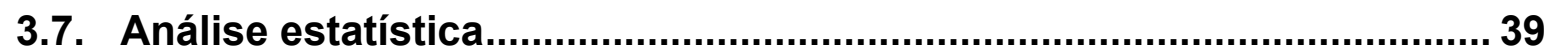

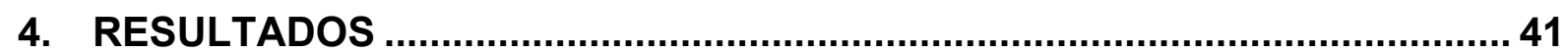

4.1. Modulação dos canais $K_{\text {ATP }}$ em neurônios do NTS ............................... 41

4.1.1. Efeito do fechamento dos canais $K_{\text {ATP }}$ em neurônios do NTS ................ 41

4.1.2. Efeito da abertura dos canais $K_{\text {ATP }}$ em neurônios do NTS ......................4 47

4.2. Sensibilidade à baixa glicose extracelular em neurônios do NTS.......... 49

4.2.1. Efeito da baixa glicose extracelular no potencial de membrana em

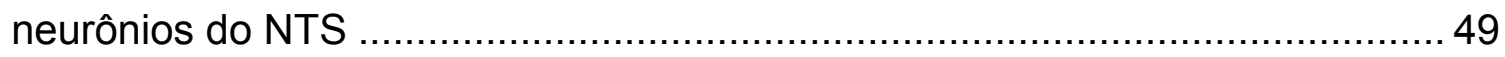

4.2.2. Efeito da baixa glicose extracelular na resistência de entrada da

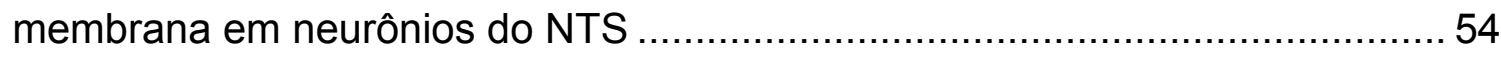


4.2.3. Efeito do aumento da concentração da glicose interna na sensibilidade à baixa glicose extracelular em neurônios do NTS

4.2.4. Influência da idade dos animais na resposta à baixa glicose extracelular e à tolbutamida em neurônios do NTS.

4.2.5. Análise da condutância iônica sensível à baixa glicose extracelular em neurônios do NTS

4.2.6. Modulação dos canais $\mathrm{K}_{\text {ATP }}$ na sensibilidade à baixa glicose extracelular em neurônios do NTS

4.2.7. Sensibilidade à baixa glicose extracelular em neurônios do NTS incubados em condição hiperglicêmica.

4.2.8. Efeito da exposição prolongada à baixa glicose extracelular em

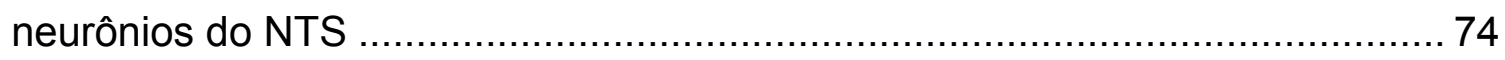

4.3. Sensibilidade à baixa glicose extracelular em astrócitos do NTS ......... 76

4.3.1. Identificação de astrócitos para imagens de cálcio.............................. 77

4.3.2. Efeito da baixa glicose extracelular na atividade de cálcio em astrócitos

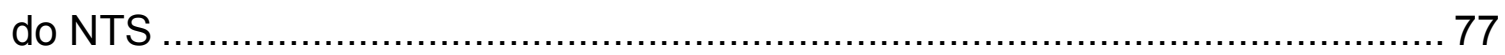

4.3.3. Efeito da baixa glicose extracelular na gliotransmissão no NTS

4.3.4. Sensibilidade à baixa glicose extracelular e gliotransmissão em astrócitos do NTS incubados em condição hiperglicêmica

4.3.5. Monitoramento da atividade de cálcio em astrócitos do NTS sob microscopia multifóton

5. DISCUSSÃO 90

5.1. Os canais $K_{\text {ATP }}$ modulam a excitabilidade elétrica e a sensibilidade à baixa glicose extracelular em neurônios do NTS. 90

5.2. A despolarização induzida pela baixa glicose extracelular é um mecanismo dependente de voltagem em neurônios do NTS ..........................94

5.2.1. A influência da idade na sensibilidade à baixa glicose extracelular ........97

5.3. A sinalização por $I_{3} R 2$ modula a atividade de cálcio citosólico em resposta à baixa glicose extracelular em astrócitos do NTS ..........................98

5.4. Evidências de gliotransmissão regulada pela concentração de glicose extracelular no NTS

5.5. Implicações fisiológicas da sensibilidade à baixa glicose extracelular em astrócitos e neurônios do NTS. 104 
6. CONCLUSÕES

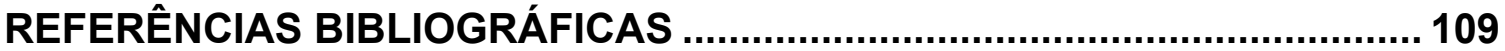

ANEXO A - Artigo publicado relacionado à tese

ANEXO B - Artigo publicado não-relacionado à tese 
INTRODUÇÃO 


\section{INTRODUÇÃO}

\subsection{Glicose: substrato energético essencial ao cérebro}

A glicose é o principal precursor energético para o cérebro manter o metabolismo celular e funcionamento (Mergenthaler et al., 2013). Apesar de corresponder por apenas $2 \%$ do peso corporal, o cérebro consome cerca de $20 \%$ da glicose circulante, tornando-se o órgão que apresenta a maior taxa metabólica em condições fisiológicas normais (Raichle \& Gusnard, 2002). Majoritariamente, a energia derivada da glicose cerebral é utilizada para a manutenção do gradiente eletroquímico, geração da atividade elétrica e produção de neurotransmissores (Harris et al., 2012; Howarth et al., 2012).

Durante a evolução, algumas propriedades bioquímicas parecem ter sido fundamentais para que a glicose se tornasse o substrato energético de maior relevância ao cérebro. A glicólise é um processo rápido para a geração de energia, sendo ideal para suprir a alta demanda energética celular. Além disso, a utilização da glicose proporciona um ambiente cerebral menos oxidativo e com menor toxicidade em comparação a substratos de origem lipídica ou protéica, o que beneficia a integridade das células, principalmente neurônios (Barros, 2013; Mergenthaler et al., 2013).

O cérebro depende da constante captação de glicose circulante para suprir sua demanda energética, visto que o armazenamento de glicogênio cerebral é baixo (Obel et al., 2012; Magistretti \& Allaman, 2015). Esta captação é realizada na barreira hematoencefálica, a qual é composta por capilares contínuos nãofenestrados envoltos por células endoteliais em tight junctions, pericítios e pésterminais de astrócitos. Tal conformação permite seletividade no movimento de íons, moléculas e células entre a circulação sistêmica e o ambiente cerebral, o que proporciona maior proteção ao sistema nervoso central (Daneman \& Prat, 2015).

$\mathrm{Na}$ barreira hematoencefálica, a glicose é captada pelas células endoteliais por difusão facilitada, principalmente via transportador de glicose independente de sódio tipo 1 (GLUT1) (Patching, 2017). Este processo é favorecido pelo gradiente de concentração estabelecido entre os vasos sistêmicos, contendo aproximadamente 5 $\mathrm{mM}$ de glicose $(90 \mathrm{mg} / \mathrm{dL})$, e os capilares cerebrais, os quais possuem cerca de 2,5 $\mathrm{mM}$ de glicose (McNay et al., 2001; Cryer, 2006). Pelo fato dos pés-terminais de astrócitos envolverem 99,7\% dos capilares cerebrais (Mathiisen et al., 2010), 
neurônios não tem acesso livre à glicose. Deste modo, os astrócitos são importantes controladores do fluxo de glicose para o interstício cerebral (Belanger et al., 2011).

Uma vez no espaço intersticial, a captação de glicose é primariamente realizada por GLUT3 em neurônios e GLUT1 em astrócitos (Barros, 2013; Benarroch, 2014). Outros GLUTs também são expressos na membrana destes tipos celulares; por exemplo, GLUT2, que possui a menor afinidade para glicose dentre os GLUTs e é um componente significativo para mecanismos envolvidos na homeostase da glicose (Marty et al., 2005; Thorens, 2015), e GLUT4, que é regulado pela insulina e pode ser mobilizado durante alto gasto energético em neurônios (Pearson-Leary \& McNay, 2016; Ashrafi et al., 2017).

No meio intracelular, a glicose é rapidamente fosforilada por uma hexocinase para produzir glicose-6-fosfato, a qual pode ser direcionada a diferentes vias metabólicas: (1) glicólise, levando à produção de lactato ou ao metabolismo mitocondrial para gerar energia; (2) via das pentose-fosfato, gerando substratos para processos de biossíntese e antioxidação, e; (3) glicogênese (particularmente em astrócitos), promovendo o armazenamento de energia sob a forma de glicogênio para ser mobilizado sob demanda (Dienel, 2012; Barros, 2013).

No entanto, condições de hipoglicemia, as quais limitam a disponibilidade de energia, podem debilitar a captação e o metabolismo da glicose celular (Litvin et al., 2013; Rooijackers et al., 2016). A hipoglicemia cerebral compromete funções neurais rapidamente, podendo levar à irritabilidade, disfunções cognitivas, perda da consciência e morte neuronal (Rosenthal et al., 2001; Cryer, 2007). Portanto, diversos componentes periféricos e centrais atuam em respostas contrarregulatórias à hipoglicemia para que a disponibilidade de glicose no cérebro mantenha-se em valores fisiológicos adequados (Cryer, 2006; Marty et al., 2007; Donovan \& Watts, 2014).

\subsection{O núcleo do trato solitário na regulação da homeostase da glicose}

O núcleo do trato solitário (NTS) é uma área multimodal localizada no bulbo dorsolateral do tronco encefálico, composta por grupos heterogêneos de neurônios que processam informações envolvidas em vários processos fisiológicos, como por exemplo no baro- e quimiorreflexo (Gourine et al., 2010; Accorsi-Mendonça et al., 2011; Zoccal et al., 2014), e no controle da motilidade e secreção no trato gastrointestinal (Hermann et al., 2014). Adicionalmente, a participação do NTS na 
regulação da homeostase da glicose tem ganhado bastante relevância nos últimos anos (Marty et al., 2007; Donovan \& Watts, 2014).

O NTS é o principal local aferente para fibras viscerossensoriais provenientes de neurônios periféricos sensíveis à glicose (Grill \& Hayes, 2009), e neurônios do NTS conectam-se a outras áreas centrais envolvidas na homeostase energética, principalmente ao hipotálamo (Verberne et al., 2014). Além disso, neurônios do NTS projetam-se densamente para o núcleo motor dorsal do vago (DMNX), onde os corpos celulares de neurônios pré-ganglionares parassimpáticos estão localizados (Marty et al., 2007). Deste modo, o NTS torna-se um centro integrativo chave para respostas autonômicas relacionadas a alterações da glicemia, conforme ilustrado na Figura 1.

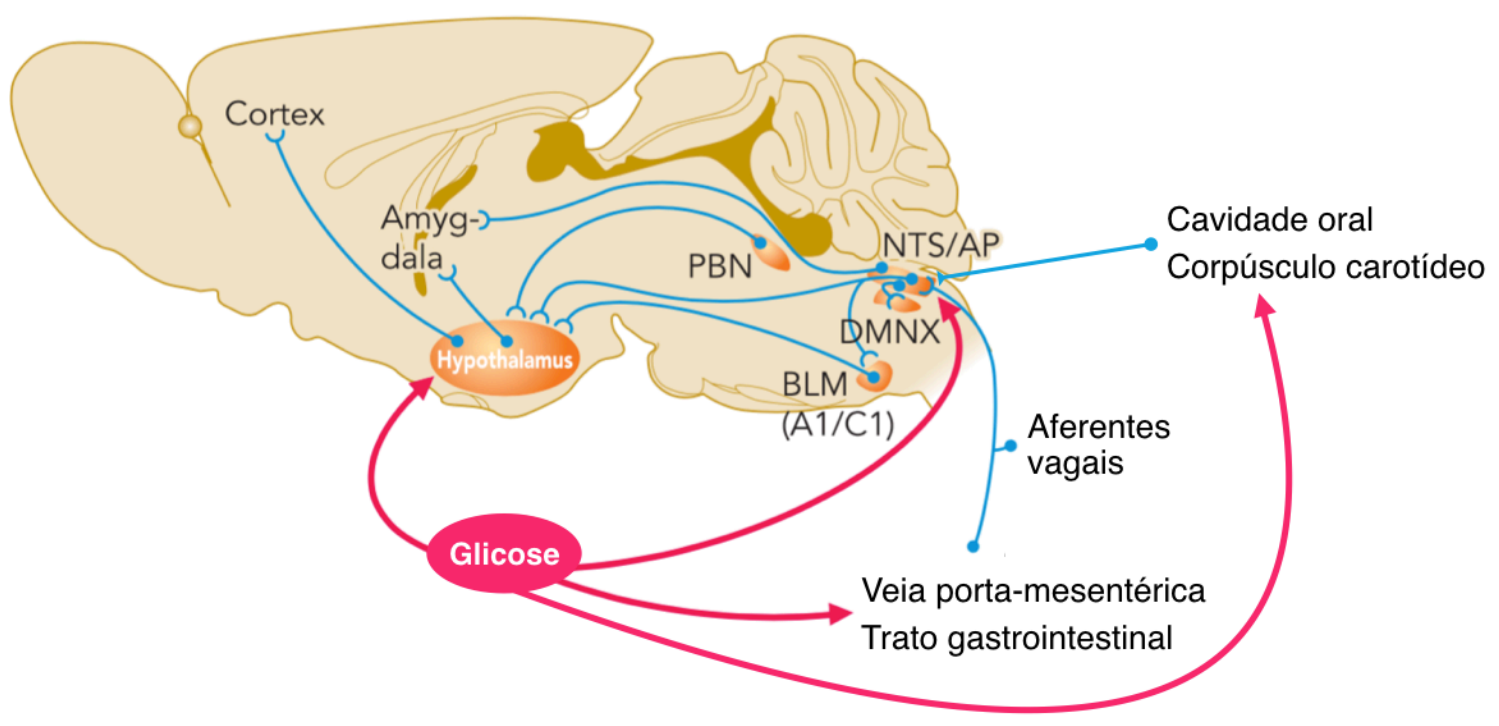

Figura 1. O papel integrativo do núcleo do trato solitário na regulação neural da homeostase da glicose. Flutuações de glicose extracelular ativam glicossensores neuronais periféricos, os quais projetam-se para o núcleo do trato solitário (NTS). Alterações da concentração de glicose também podem regular a excitabilidade de neurônios do NTS, bem como neurônios hipotalâmicos. Adicionalmente, neurônios do NTS integram sinais com áreas corticolímbicas, e principalmente projetam-se ao núcleo motor dorsal do vago (DMNX) para regular respostas autonômicas à hipoglicemia. Adaptado de Marty et al. (2007).

Particularmente, o NTS está associado a respostas contrarregulatórias à hipoglicemia, incluindo modulação da secreção hormonal, motilidade gástrica, aumento do tônus simpático, e alterações do comportamento alimentar (Donovan \& Watts, 2014; Steinbusch et al., 2015). Por exemplo, a detecção da baixa glicose por glicossensores localizados na veia porta-mesentérica induz imunorreatividade para o 
marcador de atividade celular c-Fos em neurônios do NTS, e a desaferenciação porta-mesentérica suprime este efeito (Bohland et al., 2014). Neurônios do NTS que expressam colecistocinina atuam no controle do apetite (D'Agostino et al., 2016), e a modulação de receptores N-metil-D-aspartato (NMDA) em neurônios do NTS pode controlar a produção de glicose hepática (Lam et al., 2010). Adicionalmente, condições hipoglicêmicas aumentam a atividade elétrica no nervo do seio carotídeo, o qual propaga a maioria dos sinais para o NTS (Gao et al., 2014).

Além de neurônios, os astrócitos têm emergido como importantes componentes envolvidos no controle glicêmico (Belanger et al., 2011; Marina et al., 2017; Nortley \& Attwell, 2017). Por exemplo, camundongos knockout para Glut2, os quais mantiveram a secreção de insulina normalmente regulada devido à expressão transgênica de GLUT1 nas células- $\beta$ pancreáticas, apresentaram secreção de glucagon comprometida em resposta à hipoglicemia. Após a reexpressão seletiva de GLUT2 em astrócitos, mas não em neurônios, a secreção de glucagon foi reestabelecida. Interessantemente, a reexpressão de GLUT2 em astrócitos também recuperou a imunorreatividade para c-Fos induzida por um inibidor da via glicolítica em neurônios do NTS (Marty et al., 2005). Adicionalmente, outros estudos mostram a participação de astrócitos do NTS na regulação da motilidade gástrica (McDougal et al., 2011; Hermann et al., 2014) e no controle do apetite e peso corporal (Reiner et al., 2016).

Em suma, o NTS é um importante modulador de mecanismos contrarregulatórios autonômicos à hipoglicemia, e tanto neurônios como astrócitos podem participar de respostas fisiológicas induzidas por alterações do metabolismo da glicose.

\subsection{Neurônios sensíveis à glicose no núcleo do trato solitário}

A ideia de que o cérebro poderia conter células especializadas em transduzir alterações da concentração de glicose local em sinais químicos e elétricos para controlar a homeostase energética foi primeiramente postulada por Jean Mayer em 1953, baseando-se principalmente em estudos conduzidos no hipotálamo (Mayer, 1953). Foi então que, em 1964, um grupo demonstrou por análises eletrofisiológicas que neurônios de fatias hipotalâmicas eram capazes de responder a alterações da concentração de glicose extracelular por meio da excitabilidade elétrica (Anand et al., 1964). 
Atualmente, estes neurônios são classificados como: neurônios excitados por glicose, quando aumentam sua atividade elétrica em resposta ao aumento da concentração de glicose extracelular, ou neurônios inibidos por glicose, quando aumentam sua atividade elétrica em resposta à baixa glicose extracelular (Thorens, 2012; Routh et al., 2014). Além disso, sabe-se que neurônios sensíveis à glicose estão localizados em diversos sítios periféricos e áreas centrais, incluindo o NTS (Donovan \& Watts, 2014).

A presença de capilares fenestrados (Gross et al., 1990) e localização adjacente à área postrema, um órgão circumventricular (Barraco et al., 1992), tornam o NTS uma região propícia ao monitoramento da composição dos fluidos cerebrais. De fato, sinais metabólicos e nutricionais no NTS (e.g., glicose e metabólitos) podem deflagrar respostas fisiológicas necessárias para a regulação da homeostase energética (Zhao et al., 2012; D'Agostino et al., 2016). Por exemplo, inibidores do metabolismo da glicose injetados no NTS aumentam a secreção de glucagon e induzem à ingestão alimentar (Ritter et al., 2000; Andrew et al., 2007).

Ambos os subtipos de neurônios sensíveis à glicose são encontrados no NTS. Neurônios do NTS excitados por glicose respondem a alterações da concentração de glicose extracelular por um mecanismo dependente de glucocinase e canais para potássio sensíveis ao ATP (K $\mathrm{K}_{\mathrm{ATP}}$ ) (Boychuk et al., 2015; Roberts et al., 2017), e portanto, por um processo dependente do metabolismo da glicose. Por outro lado, neurônios do NTS ativados por baixa glicose mostram maior heterogeneidade de resposta frente a alterações da glicose extracelular, embora também dependam do metabolismo da glicose para ativação (Balfour \& Trapp, 2007; Thorens, 2012). Por exemplo, a diminuição da concentração de glicose extracelular ou a aplicação de inibidores da glicólise aumentam a concentração de cálcio intracelular em neurônios do NTS (McDougal et al., 2013), e a depleção de glicose no meio externo pode despolarizar o potencial de membrana em neurônios do NTS (Balfour et al., 2006; Mimee \& Ferguson, 2015).

Importantemente, neurônios ativados pela diminuição da concentração de glicose extracelular podem deflagrar respostas autonômicas. Lamy et al. (2014) mostraram que neurônios GABAérgicos do NTS despolarizaram em resposta à baixa glicose, e a ativação optogenética destes neurônios resultou no aumento da secreção de glucagon. Além disso, a aplicação de inibidores do metabolismo da glicose no NTS, o que simula uma condição hipoglicêmica, induz à motilidade 
gástrica (Hermann et al., 2014). Portanto, neurônios do NTS são sensíveis a flutuações da concentração de glicose extracelular e dependem do metabolismo da glicose para resposta. Além disso, a privação de glicose extracelular em neurônios do NTS pode desencadear mecanismos contrarregulatórios autonômicos, o que enfatiza o papel do NTS nas respostas fisiológicas à hipoglicemia.

\subsubsection{Canais para potássio sensíveis ao ATP}

O canal $\mathrm{K}_{\mathrm{ATP}}$ é formado por um complexo heterogêneo composto por quatro subunidade $\mathrm{K}_{\mathrm{ir}} 6 . \mathrm{x}$ formadoras do poro e quatro subunidades regulatórias do receptor de sulfonilureia (SURx). Este canal iônico conduz uma corrente retificadora de entrada para potássio, a qual é inibida pela ligação de ATP à subunidade $\mathrm{K}_{\mathrm{ir}} 6 . \mathrm{x}$ e estimulada pela interação de ADP com sítios de ligação a nucleotídeos na subunidade SURx (Hibino et al., 2010). Portanto, os canais $\mathrm{K}_{\mathrm{ATP}}$ funcionam como sensores metabólicos, acoplando o metabolismo celular à excitabilidade elétrica em células de diversos tecidos, incluindo os neurônios (Nichols, 2006) e, classicamente, as células- $\beta$ pancreáticas (Ashcroft \& Rorsman, 2013).

Em condições de baixo metabolismo celular, onde a razão ATP/ADP é baixa, a abertura dos canais $\mathrm{K}_{\mathrm{ATP}}$ leva à hiperpolarização do potencial de membrana, o que é considerado um efeito neuroprotetor tradicional (Nichols, 2006). Por outro lado, os canais $\mathrm{K}_{\mathrm{ATP}}$ se fecham em resposta ao aumento do metabolismo, onde a razão ATP/ADP é alta, induzindo despolarização do potencial de membrana e consequente ativação neuronal (Hibino et al., 2010).

Além disso, os canais $\mathrm{K}_{\text {ATP }}$ são alvos de drogas terapêuticas, principalmente as relacionadas ao tratamento do diabetes tipo 2. Sulfonilureias, como a glibenclamida, ligam-se à subunidade SUR e fecham os canais $K_{\text {ATP }}$ em células- $\beta$ pancreáticas, levando ao aumento da secreção de insulina (Proks et al., 2002). Em contrapartida, alguns fármacos agem na abertura dos canais $\mathrm{K}_{\text {ATP }}$ por meio da interação com a subunidade SUR, como diazoxida e pinacidil, o que estimula a atividade do canal e induz hiperpolarização do potencial de membrana (Gribble \& Reimann, 2003; McTaggart et al., 2010).

No NTS, as subunidades $\mathrm{K}_{\mathrm{ir}} 6.2$ e SUR1 são expressas em neurônios sensíveis à glicose (Balfour et al., 2006; Halmos et al., 2015). Conforme descrito na seção anterior, neurônios excitados por glicose dependem da modulação dos canais $\mathrm{K}_{\mathrm{ATP}}$, pois a aplicação de antagonistas destes canais inibe a alteração da atividade 
elétrica induzida pelo aumento da concentração de glicose extracelular (Dallaporta et al., 2000; Balfour et al., 2006; Boychuk et al., 2015). De fato, neurônios excitados por glicose utilizam um sistema similar às células- $\beta$ pancreáticas, respondendo a flutuações da disponibilidade de glicose no ambiente extracelular por um mecanismo dependente de GLUT/glucocinase/K

No entanto, a modulação dos canais $\mathrm{K}_{\mathrm{ATP}}$ na sensibilidade à baixa glicose extracelular em neurônios do NTS não está bem elucidada. Curiosamente, alguns estudos mostram a expressão de subunidades dos canais $\mathrm{K}_{\mathrm{ATP}}$ em neurônios do NTS que não responderam a alterações da concentração de glicose extracelular (Dallaporta et al., 2000; Balfour et al., 2006), o que sugere que a maquinaria celular necessária para a resposta pode não ser expressa nestes neurônios. Por outro lado, a atividade dos canais $\mathrm{K}_{\mathrm{ATP}}$ e outros fatores metabólicos poderiam influenciar a resposta à baixa glicose extracelular em neurônios do NTS.

\subsection{Astrócitos na regulação da homeostase da glicose}

Por muito tempo os astrócitos foram considerados somente células de suporte ao tecido neuronal por não apresentarem excitabilidade elétrica (Haydon, 2016). Entretanto, a observação de que a aplicação de glutamato induziu elevação de cálcio em astrócitos em cultura (Cornell-Bell et al., 1990) despertou o interesse de muitos pesquisadores. Atualmente, após quase 30 anos da descoberta, não só sabemos que os astrócitos respondem a estímulos por meio de oscilações de cálcio, mas que também podem liberar suas próprias moléculas sinalizadoras (i.e., gliotransmissores) para regular a excitabilidade neuronal, processamento da informação e plasticidade (Araque et al., 2014; Shigetomi et al., 2016; MartinFernandez et al., 2017).

Os astrócitos possuem características interessantes para o controle do metabolismo da glicose no cérebro. Primeiramente, os pés-terminais de astrócitos envolvem virtualmente toda a extensão dos capilares cerebrais (Mathiisen et al., 2010), e portanto situando os astrócitos em uma localização espacial estratégica para o monitoramento da glicose cerebral circulante (Belanger et al., 2011; Stobart \& Anderson, 2013). Além disso, a citoarquitetura celular dos astrócitos os tornam idealmente posicionados para detectar/conduzir moléculas e sinais metabólicos entre neurônios e vasos sanguíneos no espaço intersticial (Barros, 2013; Marina et al., 2017). 
Algumas características metabólicas também fortalecem a ideia de que os astrócitos são essenciais para a homeostase da glicose no ambiental cerebral. Por exemplo, a expressão de enzimas glicolíticas em astrócitos é maior em comparação a neurônios (Lovatt et al., 2007; Cahoy et al., 2008) e, de fato, a taxa do metabolismo da glicose é mais alta em astrócitos (Bittner et al., 2010). Além disso, astrócitos podem armazenar glicogênio devido à atividade da enzima glicogênio sintase, o que não ocorre em neurônios (Obel et al., 2012).

Em conjunto, estas e outras características tornaram-se base para a hipótese formulada por Pellerin e Magistretti, denominada transporte de lactato astrócitoneurônio, que propõe que astrócitos captam constantemente a glicose do meio extracelular para ser metabolizada a lactato, sendo então transportado aos neurônios para suprir a demanda energética neuronal (Pellerin \& Magistretti, 2012). Esta hipótese tem sido amplamente corroborada, (Genc et al., 2011; Wyss et al., 2011; Nortley \& Attwell, 2017), apesar de controvérsias (Dienel, 2012, 2017; Bak \& Walls, 2018).

Estudos mostram que astrócitos podem desencadear respostas fisiológicas a sinais metabólicos (García-Cáceres et al., 2016; Fernandez et al., 2017), incluindo astrócitos do NTS (Marty et al., 2005). Por exemplo, a regulação da ingestão alimentar e o controle do peso corporal podem ser modulados pelo peptídeo semelhante ao glucagon 1 (GLP-1) em astrócitos do NTS de ratos (Reiner et al., 2016). A aplicação sistêmica de insulina ou inibidores da glicólise depende da integridade metabólica de astrócitos do NTS para induzir à motilidade gástrica (Hermann et al., 2014), e condições hipoglicêmicas induzem aumento da concentração citosólica de cálcio em astrócitos do NTS (McDougal et al., 2013).

Em conjunto, estes estudos sugerem que astrócitos do NTS são componentes importantes para respostas fisiológicas a alterações do metabolismo da glicose. Entretanto, a regulação da atividade de cálcio frente a flutuações da concentração de glicose extracelular em astrócitos do NTS é desconhecida. 
OBJETIVOS 


\section{OBJETIVOS}

\subsection{Objetivo geral}

O presente estudo visou avaliar a sensibilidade à baixa glicose extracelular em neurônios e astrócitos do núcleo do trato solitário (NTS). Objetivamos também estudar os mecanismos de resposta à baixa glicose em neurônios e astrócitos do NTS, assim como a sinalização astrócito-neurônio induzida pela diminuição da concentração de glicose extracelular. Adicionalmente, avaliamos a influência de uma condição hiperglicêmica na sensibilidade à baixa glicose em neurônios e astrócitos do NTS.

\subsection{Objetivos específicos}

Como objetivos específicos, visamos avaliar:

a) o efeito de moduladores dos canais para potássio sensíveis ao ATP (K $\left.\mathrm{K}_{\mathrm{ATP}}\right)$ nas propriedades eletrofisiológicas de neurônios do NTS;

b) o efeito da perfusão de solução contendo baixa glicose nas propriedades eletrofisiológicas de neurônios do NTS;

c) o efeito da modulação dos canais $\mathrm{K}_{\mathrm{ATP}}$ na sensibilidade à baixa glicose extracelular em neurônios do NTS;

d) o efeito da perfusão da baixa glicose na atividade de cálcio em astrócitos do NTS;

e) a participação da via de sinalização do receptor de inositol 1,4,5-trifosfato tipo $2\left(\mathrm{IP}_{3} \mathrm{R} 2\right)$ na resposta de astrócitos do NTS à baixa glicose extracelular;

f) a comunicação astrócito-neurônio induzida pela baixa glicose extracelular no NTS;

g) a influência de uma condição hiperglicêmica na sensibilidade à baixa glicose extracelular em neurônios e astrócitos do NTS, assim como na gliotransmissão. 
MATERIAL E MÉTODOS 


\section{MATERIAIS E MÉTODOS}

\subsection{Animais e linhagens transgênicas}

Inicialmente, os experimentos eletrofisiológicos em neurônios do núcleo do trato solitário (NTS) foram realizados no Laboratório de Neurofisiologia e Sinapse do Departamento de Fisiologia da Faculdade de Medicina de Ribeirão Preto da Universidade de São Paulo (FMRP-USP). Para estes ensaios, utilizamos ratos machos Wistar (Rattus norvegicus) com 3, 6 e 11 semanas de idade, os quais foram alojados em gaiolas no biotério do Departamento de Fisiologia da FMRP-USP, sob ciclo claro/escuro 12/12 h, e com ração comercial balanceada e água ad libitum. Todos os procedimentos para o manuseio e sacrifício dos ratos Wistar foram aprovados pela Comissão de Ética no Uso de Animais (CEUA) da FMRP-USP (protocolo No 149/2015).

Posteriormente, experimentos envolvendo imagens de cálcio e eletrofisiologia em astrócitos e neurônios do NTS foram realizados no laboratório dirigido pelo Prof. Alfonso Araque, no Departamento de Neurociências da Universidade de Minnesota (UMN), em Minneapolis, MN, EUA, durante o Programa de Doutorado Sanduíche no Exterior (PDSE) fomentado pela Coordenação de Aperfeiçoamento de Pessoal de Nível Superior (CAPES). Para estes ensaios, utilizamos camundongos (Mus musculus) de ambos os sexos, os quais foram alojados em gaiolas no biotério central do Departamento de Neurociências (Wallin Medical Biosciences Building) da UMN, sob ciclo claro/escuro 12/12 h, e com ração comercial balanceada e água ad libitum. Todos os procedimentos para o manuseio e sacrifício dos camundongos foram aprovados pela Comissão Institucional de Cuidado e Uso de Animais (Institutional Animal Care and Use Committee, IACUC) da UMN, em conformidade com as diretrizes dos Institutos Nacionais de Saúde (National Institutes of Health, $\mathrm{NIH}$ ) dos EUA para o cuidado e uso de animais laboratoriais ( $\mathrm{N}^{\circ}$ 1701A34507).

As seguintes linhagens de camundongos foram utilizadas: (1) linhagem selvagem C57BL/6J (3 a 25 semanas de idade); (2) linhagem transgênica GFAPGCaMP6 (35 semanas de idade), a qual possui o indicador de cálcio GCaMP6 expresso seletivamente em astrócitos, e foi gerada por meio do cruzamento de camundongos que expressam Cre-recombinase sob controle do promotor do gene que codifica a proteína glial fibrilar ácida (GFAP) com camundongos que carregam o cassete floxed-STOP upstream ao gene que codifica GCaMP6 (Shigetomi et al., 
2010a; Shigetomi et al., 2010b), e; (3) linhagem transgênica $\mathrm{IP}_{3} \mathrm{R} 2^{-/-}$(6 semanas de idade), os quais possuem o gene que codifica para o receptor de inositol 1,4,5trifosfato tipo $2\left(\mathrm{IP}_{3} \mathrm{R} 2\right)$ deletado, permitindo realizar experimentos em condições em que a mobilização interna de cálcio dos retículos endoplasmáticos em astrócitos encontra-se comprometida. Os animais $\mathrm{IP}_{3} \mathrm{R} 2^{-/-}$foram gerados pelo sistema Cre-lox, e gentilmente doados pelo Prof. Ju Chen, atualmente situado na Faculdade de Medicina da Universidade da Califórnia San Diego, La Jolla, CA, EUA (Li et al., 2005).

A Figura 2 exemplifica a genotipagem de rotina realizada no laboratório do Prof. Araque para a confirmação da deleção do gene $\mathrm{Ip}_{3} \mathrm{r} 2$ em camundongos transgênicos Cre-IP $\mathrm{P}_{3} \mathrm{R} 2$, mostrando que a amostra do DNA obtido do animal número 3 possui a banda representativa da inserção da construção transgênica Cre em um alelo $\left(\mathrm{C}+\right.$, à esquerda) enquanto não possui a banda representativa do gene $\mathrm{Ip}_{3} \mathrm{r} 2$ no outro alelo (KO, à direita), sendo então selecionado para o estudo como animal knockout $\mathrm{IP}_{3} \mathrm{R} 2 \%$.

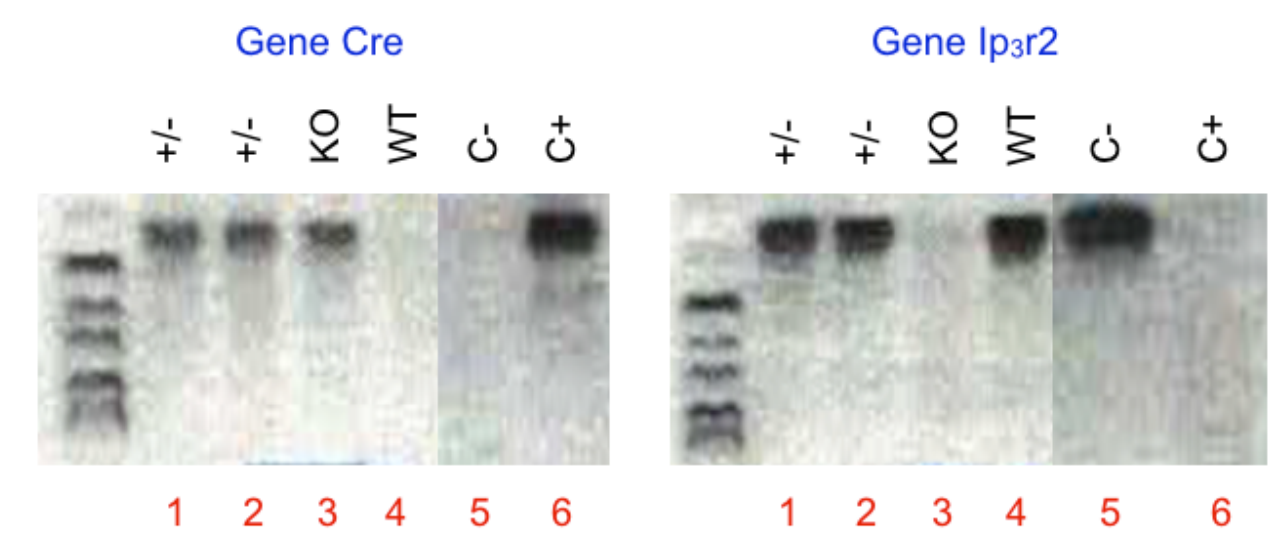

Figura 2. Confirmação da deleção knockout do gene $I p_{3} \mathrm{r} 2$ em camundongos transgênicos. Montagens de uma fotografia de um gel representativo da genotipagem de animais transgênicos Cre-lp ${ }_{3}$ r2. A amostra do DNA obtido do animal número 3 possui a banda representativa do gene Cre $(\mathrm{C}+$, à esquerda) e não possui a banda representativa do gene $\mathrm{Ip}_{3} \mathrm{r} 2$ [KO (knockout), à direita], o que confirma a construção transgênica knockout para o gene $\mathrm{Ip}_{3} \mathrm{r} 2$ neste camundongo, sendo então selecionado para o estudo. Note a genotipagem de camundongos heterozigóticos (números 1 e 2; +/-) e selvagem [número 4; WT (wild-type)]. C-, controle negativo; $\mathrm{C}+$, controle positivo. 


\subsection{Preparação das fatias do tronco encefálico}

As fatias do tronco encefálico contendo o NTS subpostremal de ratos e camundongos foram obtidas como previamente descrito (Accorsi-Mendonça et al., 2011), com pequenas modificações relatadas a seguir.

Os animais foram anestesiados com isoflurano e decapitados. Rapidamente, o cérebro foi removido e submergido em uma placa de Petri embebida com solução cerebroespinal artificial $(\mathrm{aCSF})$ cristalizada $\left(\sim 0^{\circ} \mathrm{C}\right)$, modificada para a preparação das fatias, contendo (em mM): $87 \mathrm{NaCl}, 2,5 \mathrm{KCl}, 1,25 \mathrm{NaH}_{2} \mathrm{PO}_{4}, 25 \mathrm{NaHCO}_{3}, 75$ sacarose, 25 D-glicose, 0,2 $\mathrm{CaCl}_{2}$, e $7 \mathrm{MgCl}_{2}\left(330 \mathrm{mOsm} / \mathrm{Kg} \mathrm{H}_{2} \mathrm{O}\right.$, pH 7,4 mantido por mistura carbogênica de $95 \% \mathrm{O}_{2}$ e $5 \% \mathrm{CO}_{2}$ ). O tronco encefálico foi isolado, colado à plataforma de corte, e novamente submergido em aCSF contendo a mesma composição na câmara de um vibrátomo (Vibratome 1000 Plus, Vibratome, na preparação realizada em ratos; Leica VT1200 S, Leica Biosystems, Wetzlar, Alemanha, na preparação realizada em camundongos).

Então, três a quatro fatias coronais do tronco encefálico contendo o NTS próximo à área postrema (i.e., $\pm 500 \mu \mathrm{m}$ rostral e caudal à área postrema) foram seccionadas e incubadas a $32-33^{\circ} \mathrm{C}$ por 45 minutos em aCSF normoglicêmico, contendo (em mM): $125 \mathrm{NaCl}, 2,5 \mathrm{KCl}, 1,25 \mathrm{NaH}_{2} \mathrm{PO}_{4}, 25 \mathrm{NaHCO}_{3}, 5$ D-glicose, 2 $\mathrm{CaCl}_{2}$, e $1 \mathrm{MgCl}_{2}$ (298 mOsm/Kg H $\mathrm{H}_{2} \mathrm{O}, \mathrm{pH}$ 7,35 mantido por mistura carbogênica de 95\% $\mathrm{O}_{2}$ e $5 \% \mathrm{CO}_{2}$ ). Em alguns experimentos, o aCSF de incubação continha $10 \mathrm{mM}$ de glicose (solução hiperglicêmica), na qual reduzimos 2,5 mM de $\mathrm{NaCl}$ para manter a osmolalidade igual à solução aCSF contendo $5 \mathrm{mM}$ de glicose. Após o período de incubação, as fatias foram armazenadas na mesma solução à temperatura ambiente até o início dos experimentos eletrofisiológicos e de imagem de cálcio.

\subsection{Registros eletrofisiológicos}

\subsubsection{Registros eletrofisiológicos em ratos}

As fatias do tronco encefálico contendo o NTS subpostremal de ratos foram transferidas para uma câmara posicionada em um microscópio óptico (BX51WI, Olympus, Tokyo, Japão) e continuamente perfusionadas a uma taxa de $\sim 2 \mathrm{~mL} / \mathrm{min}$ por meio de um sistema dirigido por gravidade acoplado a um sistema de aquecimento inline (TC-324B, Warner Instruments, Hamden, CT, EUA). Conforme demonstrado nas Figuras 3A e 3B, o NTS foi identificado e os neurônios foram 
visualizados por um sistema de imagem infravermelho por vídeo (Hamamatsu C2741, Hamamatsu Photonics, Shizuoka, Japão) sob óptica de contraste por interferência diferencial (DIC) com uma objetiva de $40 \mathrm{x}$, e então clampeados com eletrodos confeccionados com capilares de borossilicato (BF150-86-10, Sutter Instruments, Novato, CA, EUA) por meio de um estirador horizontal (P-87, Sutter Instruments). Os eletrodos foram preenchidos com uma solução interna contendo (em mM): 128 K-gluconato, $8 \mathrm{KCl}, 10$ HEPES, 0,5 EGTA, $4 \mathrm{Mg}_{2} \mathrm{ATP}, 0,3 \mathrm{Na}_{2} \mathrm{GTP}$, e $10 \mathrm{Na}$-fosfocreatina (295 mOsm/ $\mathrm{Kg} \mathrm{H} \mathrm{H}_{2} \mathrm{O}, \mathrm{pH} \mathrm{7,3),} \mathrm{resultando} \mathrm{em} \mathrm{uma} \mathrm{resistência} \mathrm{da}$ pipeta entre 3 e $7 \mathrm{M} \Omega$.

A

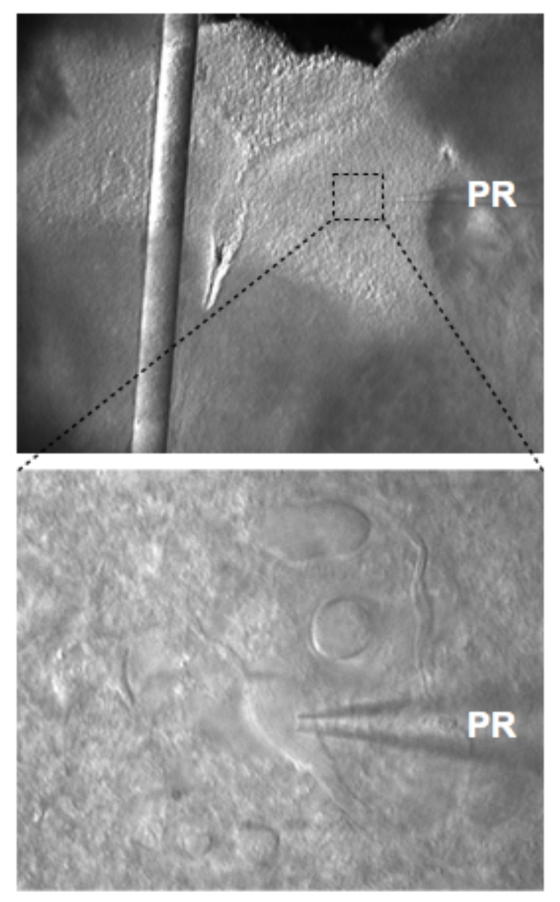

B

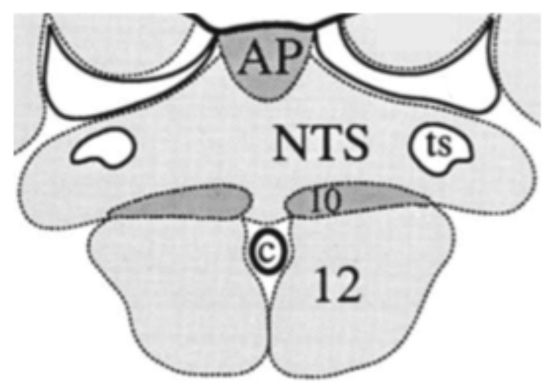

C

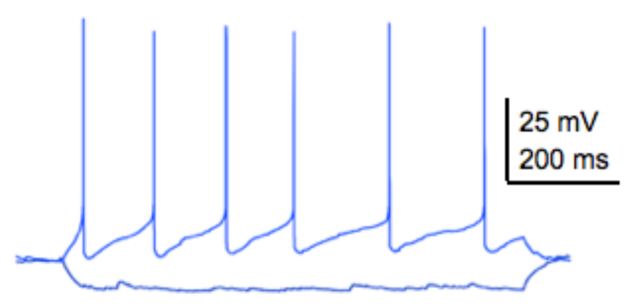

Figura 3. Identificação de neurônios do NTS. A, fotomicrografia representativa de uma fatia do tronco encefálico de rato sob óptica DIC mostra o posicionamento da pipeta de registro (PR) durante um experimento em whole-cell patch-clamp em um neurônio do NTS. A amplificação da imagem detalha o neurônio em registro. B, desenho esquemático da imagem mostrada em A indica a localização do NTS e áreas adjacentes [adaptado de Barraco et al. (1992)]. C, alterações de voltagem induzidas por injeção de correntes deflagram o disparo elétrico característico de neurônios do NTS. 10, núcleo do nervo hipoglosso; 12, núcleo motor dorsal do vago; $\mathrm{AP}$, área postrema; c, canal central; ts, trato solitário.

Os registros em whole-cell patch-clamp foram realizados com um amplificador EPC-10 (HEKA Elektronic, Lambrecht, Alemanha) utilizando o software de aquisição 
PatchMaster (HEKA Elektronic), em modos current- e voltage-clamp. Os dados foram adquiridos a $20 \mathrm{kHz}$ e filtrados passa-baixa a $5 \mathrm{kHz}$ (Bessel). Células com resistência em série superior a $30 \mathrm{M} \Omega$ ou que apresentaram grandes oscilações durante os registros foram descartadas. Após entrar em configuração whole-cell, aguardamos um período de $\sim 10$ min para estabilização do potencial de membrana e, durante este período, correntes despolarizantes (1000 ms) foram injetadas para induzir o disparo de potencias de ação com o intuito de confirmar a identidade neuronal da célula sob registro (Figura $3 C$ ). Durante os experimentos, a perfusão de soluções contendo tetrodotoxina [0,5 $\mu \mathrm{M}$; TTX (Alomone Labs, Jerusalém, Israel)] foi realizada após a confirmação da identidade dos neurônios do NTS.

Em registros no modo current-clamp, o potencial de membrana basal foi monitorado em aCSF normo- (5 mM de glicose) ou hiperglicêmico (10 mM de glicose) durante 10 minutos. Então, a solução contendo baixa glicose $(0,5 \mathrm{mM})$ e/ou droga foi perfundida por 10 minutos, seguida do retorno da solução inicial. Em alguns experimentos, a perfusão em baixa glicose foi realizada por períodos prolongados (20-30 minutos). Adicionamos $\mathrm{NaCl}$ ou sacarose na solução aCSF contendo $0,5 \mathrm{mM}$ de glicose para manter a osmolalidade igual às soluções basais iniciais. Adicionalmente, pulsos hiperpolarizantes (de -30 a -60 pA; $1000 \mathrm{~ms}$ ) foram aplicados a cada $15 \mathrm{~s}$ a fim de monitorar a resistência de entrada da membrana. Somente um neurônio foi registrado por fatia.

Baseado em estudos publicados envolvendo a sensibilidade à glicose extracelular em neurônios do NTS (Balfour et al., 2006; Lamy et al., 2014; Boychuk et al., 2015), bem como no perfil das respostas observadas perante ao desafio da baixa glicose na presente investigação, assumimos que um neurônio foi responsivo à baixa glicose e/ou droga quando apresentou uma clara alteração no potencial de membrana induzida por tais condições. Salienta-se que, na maioria das vezes, as oscilações do potencial de membrana foi robusta. Uma análise da despolarização induzida pela baixa glicose extracelular mostra duas populações de neurônios distintas, uma cujo potencial de membrana varia até $3 \mathrm{mV}$, e outra que varia acima de $4 \mathrm{mV}$ (Figura 4), tanto em neurônios incubados em condição normo- ou hiperglicêmica. Portanto, consideramos neurônios responsivos à baixa glicose e/ou droga quando apresentaram alterações do potencial de membrana superior a $\pm 3 \mathrm{mV}$. 
A

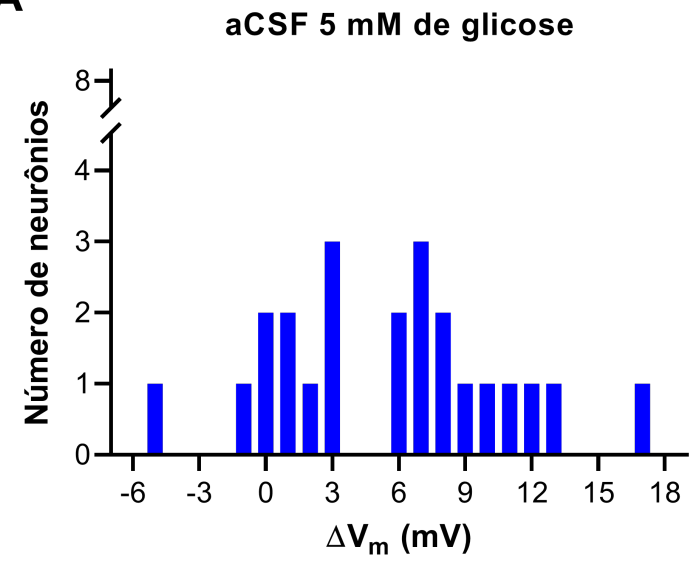

B

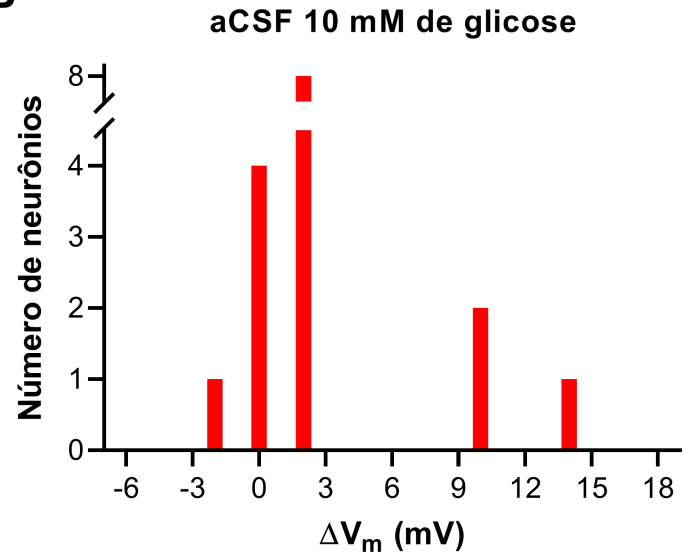

Figura 4. Populações distintas de neurônios do NTS em relação à resposta despolarizante induzida pela baixa glicose extracelular. Em ambas condições normo- e hiperglicêmica, a análise da amplitude da alteração do potencial de membrana $\left(V_{m}\right)$ em resposta à baixa glicose em neurônios mostra a existência de duas populações distintas: uma cujo potencial de membrana varia até $3 \mathrm{mV}$, a outra que varia acima de $4 \mathrm{mV}$. aCSF, solução cerebroespinal artificial.

Em registros no modo voltage-clamp, os neurônios foram mantidos em um potencial de holding de $-70 \mathrm{mV}$, e a alteração de voltagem variou de -125 a $-65 \mathrm{mV}$ em sete passos de $10 \mathrm{mV}$ com duração de $500 \mathrm{~ms}$. A resistência em série foi compensada em $60 \%$. Durante os registros em voltage-clamp, os seguintes bloqueadores sinápticos foram adicionados às soluções de perfusão: picrotoxina (100 $\mu \mathrm{M})$, ácido 2-amino-5-fosfonopentoico (40 $\mu \mathrm{M}$; DLAP5), estriquinina (1 $\mu \mathrm{M})$, e 6,7-dinitroquinoxalina-2,3-diona (DNQX; $10 \mu \mathrm{M})$; todas adquiridas junto à fabricante Sigma-Aldrich (St. Louis, MO, EUA).

Os dados eletrofisiológicos foram analisados com rotinas customizadas escritas no software Igor Pro 6.37 (WaveMetrics, Portland, OR, EUA), e MiniAnalysis 6.0 (Synaptosoft, Fort Lee, NJ, EUA). Os valores de voltagem foram corrigidos para um potencial de junção líquido de $-10 \mathrm{mV}$. O potencial de repouso da membrana foi calculado pela média de todos os pontos de um histograma obtidos durante os últimos 3-4 min de registro. Todos os dados foram obtidos após a observação de um plateau de resposta. As condutâncias de membrana e os potenciais de reversão foram calculados pela regressão linear da relação corrente-voltagem.

\subsubsection{Registros eletrofisiológicos em camundongos}

O principal objetivo dos registros eletrofisiológicos realizados em neurônios do NTS de camundongos foi analisar as correntes de entrada lentas (SICs), as quais 
são geradas pela ativação de receptores N-metil-D-aspartato (NMDARs) extrassinápticos por moléculas de glutamato liberadas pelos astrócitos (Figura 5) (Fellin et al., 2004; Haydon \& Carmignoto, 2006; Navarrete \& Araque, 2008).

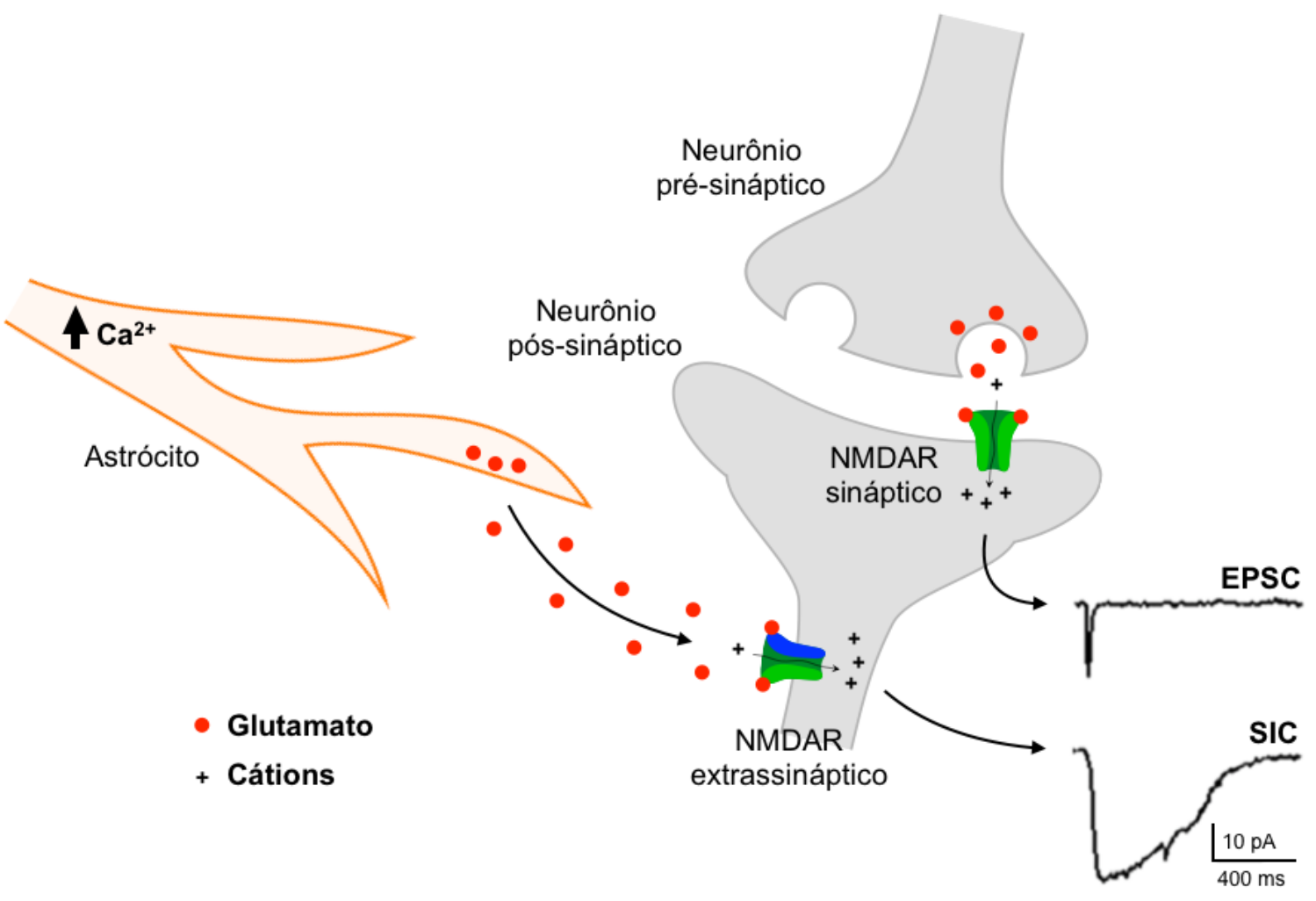

Figura 5. Gliotransmissão mediada por glutamato. O aumento da concentração de cálcio citosólico induzido por um estímulo em astrócitos leva à liberação de glutamato no espaço intersticial. Estes gliotransmissores agem em receptores NMDA (NMDAR) extrassinápticos localizados em neurônios adjacentes, gerando uma corrente de entrada com cinéticas lentas (SICs) em comparação às correntes pós-sinápticas excitatórias (EPSC). Desenho esquemático baseado em Fellin et al. (2004) e Navarrete \& Araque (2008), e registros eletrofisiológicos extraídos de Durkee et al. (2019).

Para estes experimentos, as fatias do tronco encefálico contendo o NTS subpostremal de camundongos foram transferidas para uma câmera posicionada sob um microscópio óptico (Nikon Eclipse E600FN, Nikon Instruments, Melville, NY, EUA) e continuamente perfusionadas a uma taxa de $\sim 1 \mathrm{~mL} / \mathrm{min}$ por meio de um sistema dirigido por gravidade. Os neurônios foram visualizados por um sistema de imagem infravermelho por vídeo (Hamamatsu ORCA-ER, Hamamatsu Photonics) sob óptica DIC com uma objetiva de 40 x, e então clampeados com eletrodos confeccionados com capilares de borossilicato (BF150-86-10, Sutter Instruments) por um estirador horizontal (P-1000, Sutter Instruments). Os eletrodos foram 
preenchidos com uma solução interna contendo (em mM): $135 \mathrm{KMeSO}_{4}, 10 \mathrm{KCl}, 10$ HEPES, $5 \mathrm{NaCl}, 2,5$ ATP- $\mathrm{Mg}^{2+}$, e 0,3 GTP-Na ${ }^{+}(\mathrm{pH}=7,3)$, resultando em uma resistência da pipeta entre 4 e $8 \mathrm{M} \Omega$.

Com o intuito de potencializar a amplitude das correntes mediadas por NMDARs em registro whole-cell para melhor identificação, preparamos a solução aCSF normoglicêmica sem $\mathrm{Mg}^{2+}$, contendo (em mM): $124 \mathrm{NaCl}, 2,69 \mathrm{KCl}, 1,25$ $\mathrm{KH}_{2} \mathrm{PO}_{4}, 26 \mathrm{NaHCO}_{3}, 4 \mathrm{CaCl}_{2}, 5$ D-glicose, 5 sacarose, e 0,01 glicina (Navarrete \& Araque, 2008; Durkee et al., 2019). As soluções aCSF contendo 10 ou 0,5 mM de glicose também foram preparadas na ausência de $\mathrm{Mg}^{2+}$, e em quantidades equimolares de sacarose para manter a osmolalidade igual à solução aCSF contendo $5 \mathrm{mM}$ de glicose.

Os registros em whole-cell patch-clamp foram realizados com um amplificador MultiClamp 700B (Molecular Devices, San Jose, CA, EUA) conectado ao sistema de aquisição de dados Digidata 1322A (Molecular Devices) utilizando o software pCLamp 10.0 (Molecular Devices), em modos current- e voltage-clamp. Os dados foram adquiridos a $10 \mathrm{kHz}$ e filtrados passa-baixa a $1 \mathrm{kHz}$ (Bessel). Após entrar em configuração whole-cell, aguardamos um período de $\sim 10$ min para estabilização do potencial de membrana e, durante este período, correntes despolarizantes foram injetadas para induzir o disparo de potencias de ação com o intuito de confirmar a identidade neuronal da célula sob registro. A perfusão de soluções contendo TTX (0,5 $\mu \mathrm{M}$; Alomone Labs) foi realizada após a confirmação da identidade neuronal.

Em registros no modo voltage-clamp, os neurônios foram mantidos em um potencial de holding de $-70 \mathrm{mV}$, e os eventos eletrofisiológicos foram monitorados em aCSF normo- (5 mM de glicose) ou hiperglicêmico (10 mM de glicose) durante 10 minutos. Então, a solução contendo baixa glicose $(0,5 \mathrm{mM})$ foi perfundida por 10 minutos. Em alguns experimentos, dois neurônios foram registrados por fatia em uma configuração de double-patch a fim de maximizar o número amostral.

Baseado em outros estudos (Navarrete \& Araque, 2008; Kovács \& Pál, 2017; Durkee et al., 2019), as SICs foram identificadas por apresentarem cinéticas de ativação e inativação mais lentas em comparação às correntes excitatórias póssinápticas (EPSCs) (Figura 5). Definimos SICs como correntes que apresentam Ton $>4 \mathrm{~ms}$, e com duração maior que $40 \mathrm{~ms}$. A seletividade das SICs medidas por NMDARs foram verificadas pela aplicação de DLAP5 $(40 \mu \mathrm{M})$. A quantificação das SICs foi calculada pelo número de eventos agrupados a cada $30 \mathrm{~s}$ durante cada 
registro; então, os valores médios foram obtidos. A frequência total das SICs foi quantificada pela média calculada durante dois minutos antes e depois da perfusão da solução contendo baixa glicose.

\subsection{Marcação e identificação dos astrócitos do NTS}

A identificação dos astrócitos do NTS foi conduzida por duas principais abordagens: marcação seletiva e características eletrofisiológicas (AccorsiMendonça et al., 2013; Navarrete et al., 2013; Perea et al., 2016; Martin-Fernandez et al., 2017). Primeiramente, o composto sulforodamina 101 (100 mg/Kg; SR101) foi aplicado via intraperitoneal nos camundongos, cerca de 30-40 minutos antes da preparação das fatias do tronco encefálico, até que uma coloração intensa arroxeada fosse observada nas patas e orelhas dos animais (Pérez-Alvarez et al., 2013). A SR101 é exclusivamente captada pelos astrócitos, e quando excitada por um comprimento de onda de $586 \mathrm{~nm}$ emite fluorescência na faixa do vermelho (Figura 6). Desta forma, garantimos a correta identificação dos astrócitos, uma vez que estão células não podem ser facilmente distinguidas de neurônios quando observadas sob óptica DIC.
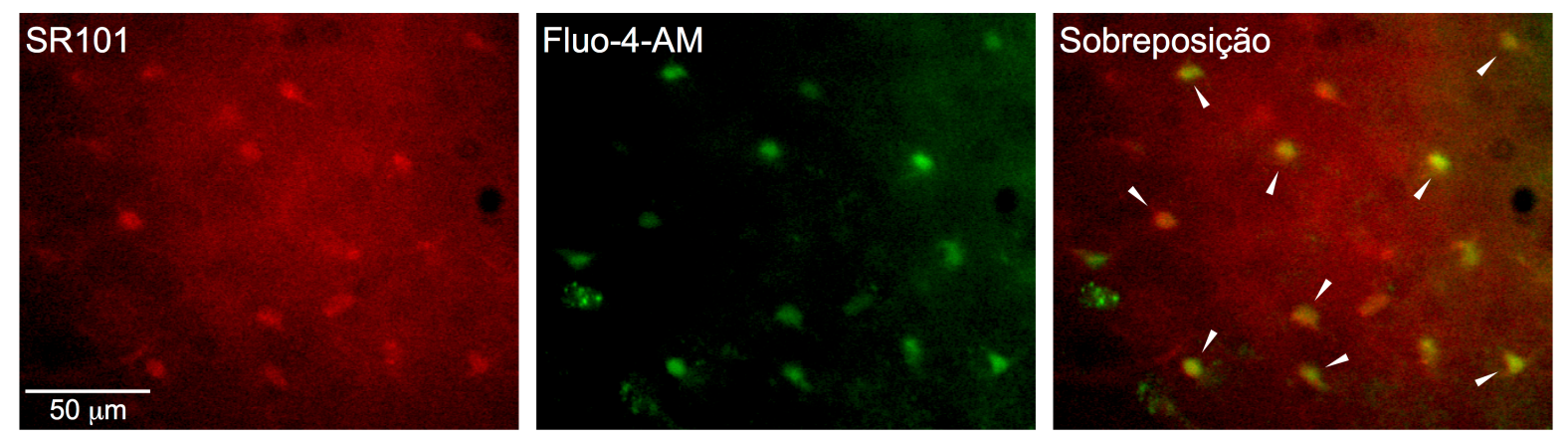

Figura 6. Identificação de astrócitos do NTS por microscopia de fluorescência. As imagens representativas mostram o sinal obtido do marcador de astrócitos sulforodamina (SR101; à esquerda) e do indicador de cálcio Fluo-4-AM (ao centro). À direita, a sobreposição das duas primeiras imagens mostra astrócitos que captaram Fluo-4-AM, sendo estão selecionados para a análise de oscilações de cálcio (indicados pela setas). Note a alta seletividade de captação de Fluo-4-AM por astrócitos.

Adicionalmente, a identidade de alguns astrócitos foi confirmada por meio de critérios eletrofisiológicos, como pela ausência de disparo de potenciais de ação após a injeção de correntes despolarizantes (Figura 7A), e pela ausência de canais de sódio dependentes de voltagem, o que culmina em uma relação corrente- 
voltagem linear (Figura 7B) (Accorsi-Mendonça et al., 2013; Navarrete et al., 2013). Para isso, registramos os astrócitos em modos whole-cell current- e voltage-clamp, este último mantendo os astrócitos em um potencial de holding de $-80 \mathrm{mV}$, com alterações de voltagem de -120 a +10 mV em 12 passos com duração de 1000 ms.

A

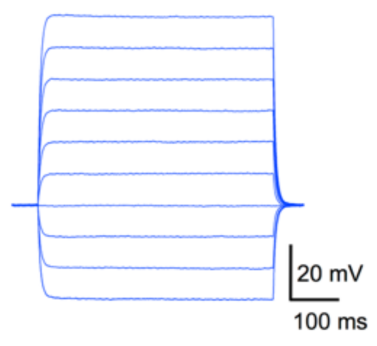

B

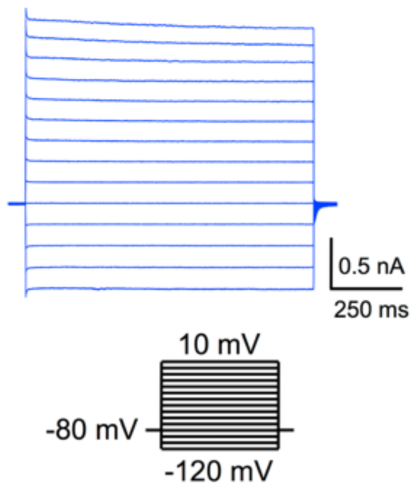

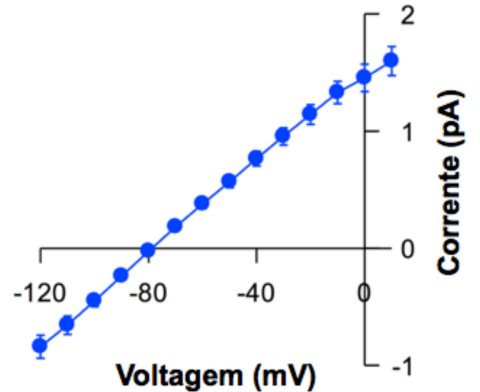

Voltagem (mV)

Figura 7. Identificação dos astrócitos do NTS por propriedades eletrofisiológicas. A, alterações de voltagem a passos de injeção de correntes em um astrócito representativo não geram atividade elétrica. $\mathbf{B}$, alterações de corrente a passos de voltagem no mesmo astrócito evidenciam a ausência de canais de sódio dependentes de voltagem (à esquerda), o que resulta em uma relação correntevoltagem linear característica de astrócitos (à direita).

\subsection{Imagem de cálcio em astrócitos do NTS}

A atividade de astrócitos do NTS foi monitorada pelos sinais correspondentes às oscilações de cálcio citosólico, as quais foram monitoradas por microscopia epifluorescente utilizando o indicador de cálcio Fluo-4-AM (Thermo Fisher Scientific, Boston, MA, EUA) em fatias obtidas de camundongos selvagens C57BL/6J e transgênicos $\mathrm{IP}_{3} \mathrm{R} 2^{-/-}$, e por microscopia multifóton em fatias obtidas de camundongos transgênicos GFAP-GCaMP6 .

\subsubsection{Imagem de cálcio por microscopia epifluorescente}

Primeiramente, as fatias do tronco encefálico contendo o NTS de camundongos $\mathrm{C} 57 \mathrm{BL} / 6 \mathrm{~J}$ ou $\mathrm{IP}_{3} \mathrm{R} 2^{-/-}$foram incubadas em uma placa de Petri embebida por 2-3 mL de solução aCSF normo- (5 mM de glicose) ou hiperglicêmica (10 mM de glicose). Então, 2-5 $\mu \mathrm{L}$ do indicador de cálcio Fluo-4-AM foram depositados sobre as fatias, atingindo uma concentração final de $5 \mu \mathrm{M}$ em $0,01 \%$ de 
Pluronic F-127 (Thermo Fisher Scientific), sendo constantemente borbulhadas por mistura carbogênica $\left(\begin{array}{lllllll}95 \% & \mathrm{O}_{2} & \text { e } & 5 \% & \mathrm{CO}_{2}\end{array}\right)$. Nestas condições, as fatias permaneceram por 20 minutos; tempo no qual a captação de Fluo-4-AM mostra-se altamente seletiva por astrócitos, e não neurônios (Figura 6).

Após este período de tempo, as fatias foram posicionadas ao microscópio epifluorescente e, simultaneamente aos registros eletrofisiológicos, as imagens de cálcio foram obtidas conforme o experimento era conduzido (Figura 8). Os sinais de cálcio em astrócitos foram adquiridos utilizando uma câmera Hamamatsu ORCA-ER (Hamamatsu Photonics) acoplada ao microscópio, em conjunto com um sistema de fluorescência (Lambda 10-3, Sutter Instruments). As fatias foram iluminadas com um LED em um comprimento de onda de $494 \mathrm{~nm}$ (emissão de fluorescência na faixa do verde; Figura 6) durante 200 ms em intervalos de 300 ms, gerando uma aquisição de imagem a cada $0,5 \mathrm{~s}$.

As análises dos sinais de cálcio foram restritas aos astrócitos que apresentaram sobreposição positiva para SR101 e Fluo-4-AM sob microscopia epifluorescente (Figura 6). As oscilações de cálcio citosólico foram estimadas pela variação do sinal fluorescente sobre a linha-base $\left(\Delta F / F_{0}\right)$ no software ImageJ $(N I H$, Bethesda, MD, EUA) por meio da obtenção manual de regiões de interesse (ROls) no soma de astrócitos. Um evento de cálcio foi considerado quando $\Delta F / F_{0}$ foi superior a 2 x o desvio padrão da linha-base, os quais também foram analisados visualmente. Os sinais de cálcio foram quantificados pelo número de oscilações de cálcio registrado nos ROls, agrupados a cada 30 s em diferentes experimentos, e os valores médios foram então obtidos. 
A

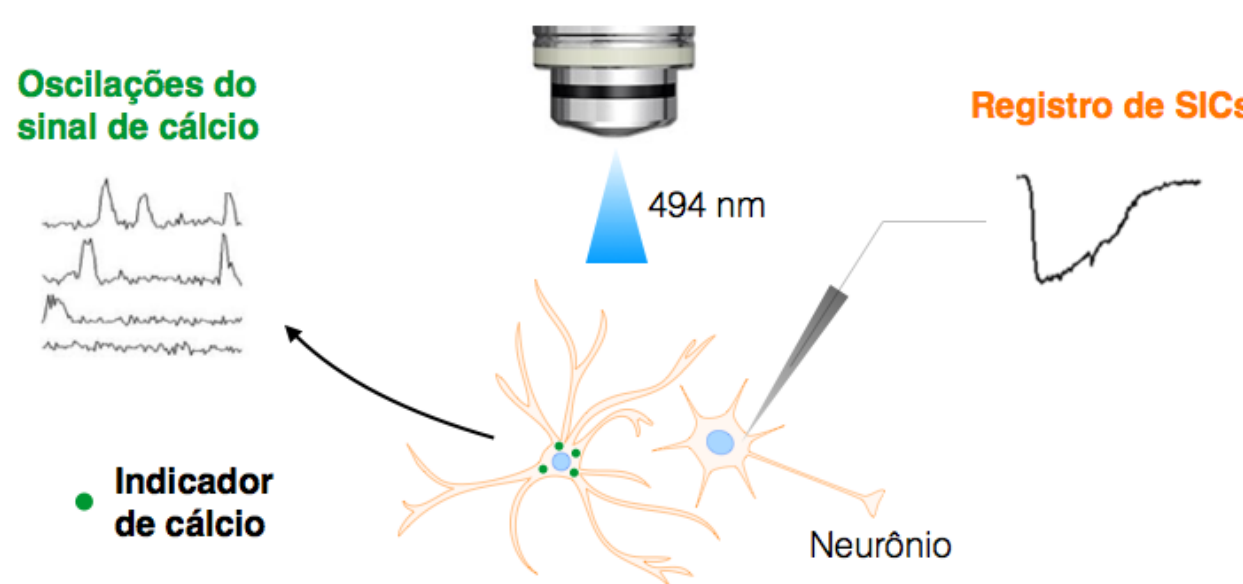

Astrócito

B

Tetrodotoxina $(0,5 \mu \mathrm{M})$

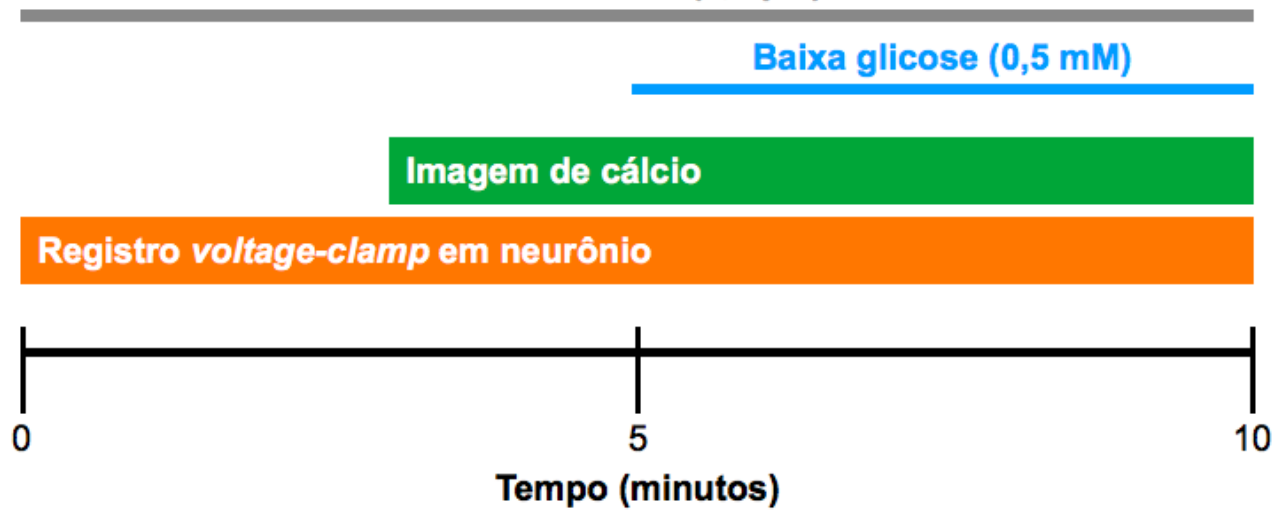

Figura 8. Design experimental para o estudo da gliotransmissão no NTS. A, sob microscopia epifluorescente, realizamos o monitoramento dos sinais de cálcio em astrócitos simultaneamente ao registro em whole-cell patch-clamp em neurônios adjacentes, com o intuito de correlacionar as oscilações de cálcio citosólico em astrócitos com a geração de correntes de entrada lentas (SICs) em neurônios vizinhos. B, o delineamento experimental consistiu no registro eletrofisiológico em neurônio do NTS em condições normoglicêmicas (aCSF contendo $5 \mathrm{mM}$ de glicose) por cinco minutos, com as imagens de cálcio iniciadas nos dois últimos minutos nestas condições. Então, a fatia foi perfundida com uma solução aCSF contendo baixa glicose $(0,5 \mathrm{mM})$, e o efeito avaliado por cinco minutos adicionais em neurônios e astrócitos simultaneamente. Todos os experimentos foram conduzidos na presença de tetrodotoxina $(0,5 \mu \mathrm{M})$. Registros eletrofisiológicos extraídos de Durkee et al. (2009).

A porcentagem de astrócitos ativos em cada condição experimental foi calculada para cada fatia; neste caso, cada fatia representou uma variável independente, e portanto, o número amostral é o número de fatias registradas. A avaliação do efeito da baixa glicose extracelular na atividade de cálcio citosólico em astrócitos foi realizada dois minutos antes e depois da perfusão da solução contendo 
baixa glicose. Deste modo, pudemos comparar as oscilações de cálcio em astrócitos com a frequência de SICs em neurônios adjacentes.

\subsubsection{Imagem de cálcio por microscopia multifóton}

Para o estudo das oscilações de cálcio em astrócitos do NTS sob microscopia multifóton, primeiramente injetamos o composto SR101 em camundongos transgênicos GFAP-GCaMP6. Apesar destes animais possuírem um indicador de cálcio geneticamente inserido apenas em astrócitos, o uso da SR101 possibilitou a confirmação de que os sinais de cálcio são oriundos exclusivamente de astrócitos (Figura 9).

Após a preparação das fatias, as espécimes foram colocadas individualmente em uma câmera sob o microscópio multifóton Leica SP5 (Leica Biosystems). Então, os astrócitos excitados por um laser em um comprimento de onda de $488 \mathrm{~nm}$ (emissão de fluorescência na faixa do verde; Figura 9) durante $100 \mathrm{~ms}$, as imagens foram adquiridas a cada $0,5 \mathrm{~s}$. Os sinais de cálcio foram obtidos do soma e processos astrocíticos.
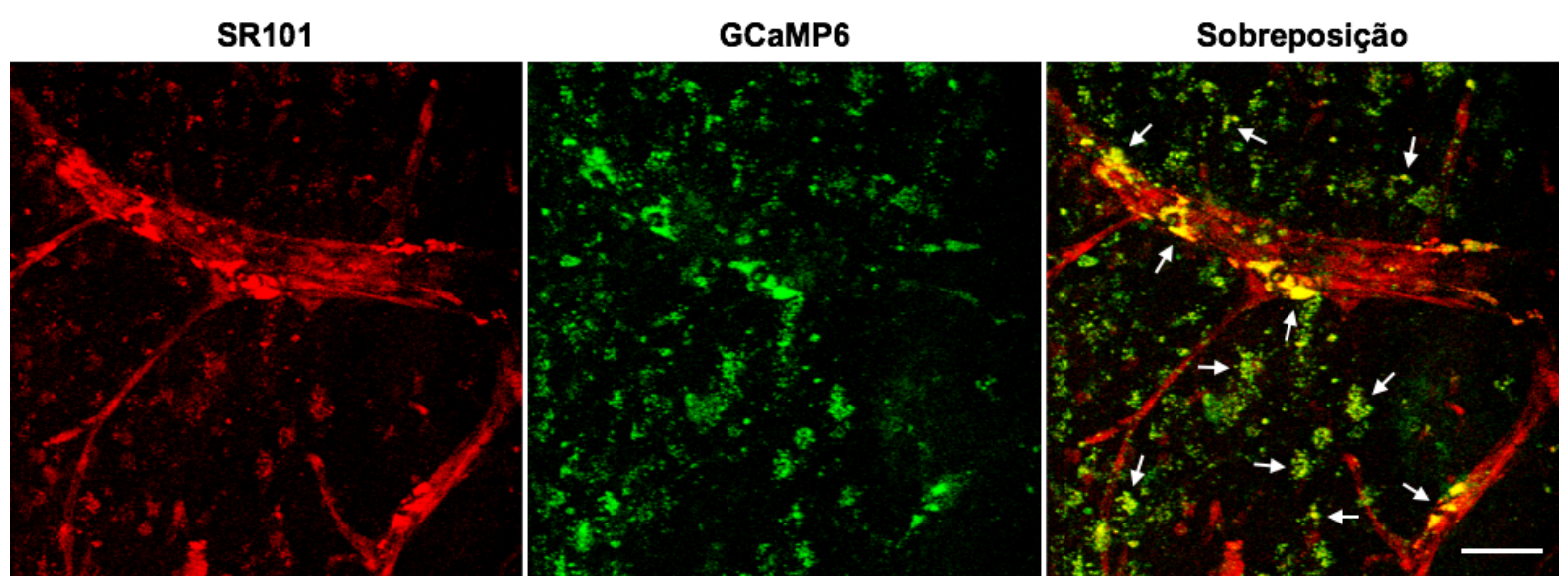

Figura 9. Identificação de astrócitos do NTS em camundongos GFAP-GCaMP6. As imagens representativas mostram o sinal obtido do marcador de astrócitos sulforodamina (SR101; à esquerda) e do indicador de cálcio GCaMP6 (ao centro). À direita, a sobreposição das duas primeiras imagens confirma a seletividade das imagens de cálcio em astrócitos (indicado pelas setas). Note que pés-terminais de astrócitos envolvem um vaso sanguíneo. Escala horizontal: $20 \mu \mathrm{m}$.

\subsection{Imunofluorescência}

Com o intuito de confirmar a seletividade dos sinais de cálcio detectados durante as imagens realizadas em astrócitos de camundongos GFAP-GCaMP6 sob microscopia multifóton, realizamos marcações por imunofluorescência. Para isso, 
camundongos GFAP-GCaMP6 foram anestesiados com isoflurano e perfundidos pelo ventrículo cardíaco esquerdo com paraformaldeído $4 \%$ em 0,1 M de tampão fosfato salina (PBS). Os cérebros foram removidos, pós-fixados em paraformaldeído, e fatiados em $50 \mu \mathrm{m}$ de espessura utilizando um vibrátomo Leica VT $1000 \mathrm{~S}$ (Leica Biosystems). As secções foram embebidas em PBS contendo $10 \%$ de soro normal de cabra (NGS) e $0,2 \%$ de Triton X-100, e então incubados over-night com 0 anticorpo primário diluído em solução bloqueadora.

Apropriadamente, os anticorpos secundários marcados com um fluorocromo (Life Technologies, Waltham, MA, EUA) foram utilizados para a detecção de sinais. Um anticorpo para GFAP (1:1000; Sigma-Aldrich) foi utilizado como marcador de astrócitos, enquanto um anticorpo para a proteína nuclear específica neuronal (1:500; NeuN; Millipore, Burlington, MA, EUA) foi utilizado como marcador de neurônios. As secções foram montadas com VectaShield (Vector Laboratories, Burlingame, CA, EUA), e então visualizadas sob microscopia confocal (Nikon NiE C2, Nikon Instruments; ou Olympus FluoView FV1000, Olympus). A colocalização dos sinais obtidos por marcadores fluorescentes foi avaliada utilizando o software ImageJ (NIH).

\subsection{Análise estatística}

As análises estatísticas foram realizadas utilizando os softwares GraphPad Prism 8.0 (GraphPad Software, La Jolla, CA, EUA) e SigmaPlot 14.0 (Systat Software, San Jose, CA, EUA). Os dados estão mostrados como valores médios \pm média do desvio padrão. Os resultados foram comparados por teste-t Student bicaudal pareado e não-pareado, e por análise de variância (ANOVA) de uma via ou medidas repetidas com teste Fisher's LSD. As correlações foram determinadas por regressão linear. As porcentagens foram comparadas com teste exato de Fisher. As diferenças estatísticas foram estabelecidas com $p<0,05\left(^{*}\right), p<0,01\left(^{* *}\right), p<0,001$ $\left({ }^{* * *}\right)$, e $\mathrm{p}<0,0001\left(^{* * * *}\right)$. 
RESULTADOS 


\section{RESULTADOS}

\subsection{Modulação dos canais $\mathrm{K}_{\mathrm{ATP}}$ em neurônios do NTS}

Os canais para potássio sensíveis ao ATP (K $\left.\mathrm{K}_{\text {ATP }}\right)$ são classicamente associados ao acoplamento do status energético celular e atividade elétrica, desencadeando despolarização do potencial de membrana em alta razão ATP/ADP citosólica, e hiperpolarização em baixa razão ATP/ADP (Nichols, 2006; Hibino et al., 2010). Neurônios do núcleo do trato solitário (NTS) expressam canais $K_{A T P}$, os quais são mais responsivos ao ATP metabólico em comparação ao ATP fornecido pela solução de pipeta em experimentos whole-cell patch-clamp, mesmo em concentrações intracelulares de 4 mM ATP (Balfour et al., 2006), a qual foi utilizada nos registros eletrofisiológicos do presente estudo.

\subsubsection{Efeito do fechamento dos canais $K_{A T P}$ em neurônios do NTS}

A fim de determinar se os canais $\mathrm{K}_{\mathrm{ATP}}$ encontram-se ativos em neurônios do NTS incubados em $5 \mathrm{mM}$ de glicose extracelular (uma concentração próxima à normoglicemia cerebral), monitoramos o potencial de membrana e a frequência de disparo de potenciais de ação em resposta à perfusão do antagonista dos canais $\mathrm{K}_{\text {ATP }}$ tolbutamida $(100 \mu \mathrm{M})$ em neurônios sob registro whole-cell patch-clamp $(\mathrm{n}=19$, nove animais).

Verificamos que a aplicação de tolbutamida despolarizou a maioria dos neurônios [14 células (73,7\%)] em 14,6 \pm 1,9 mV, de uma média de -75,7 \pm 1,9 mV para $-61,1 \pm 1,5 \mathrm{mV}$ ( $\mathrm{p}<0,0001$; Figura 10A e 10B). Todos os neurônios responsivos à tolbutamida estavam silentes, e a perfusão da solução contendo tolbutamida induziu disparo de potenciais de ação em todos eles (de uma média de $0,0 \mathrm{~Hz}$ para 2,3 $\pm 0,6 \mathrm{~Hz} ; \mathrm{p}=0,003$; Figura 10C). 


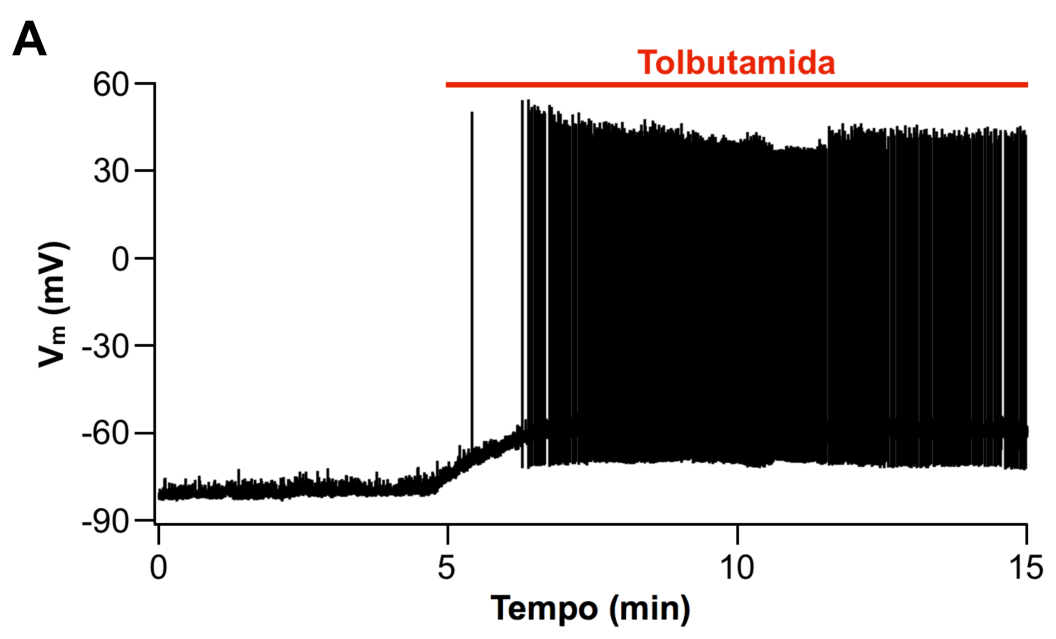

B

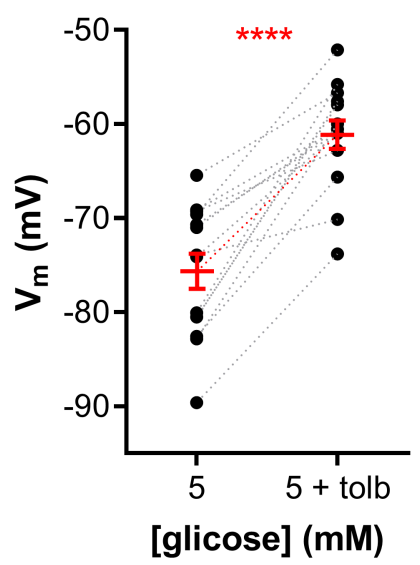

C

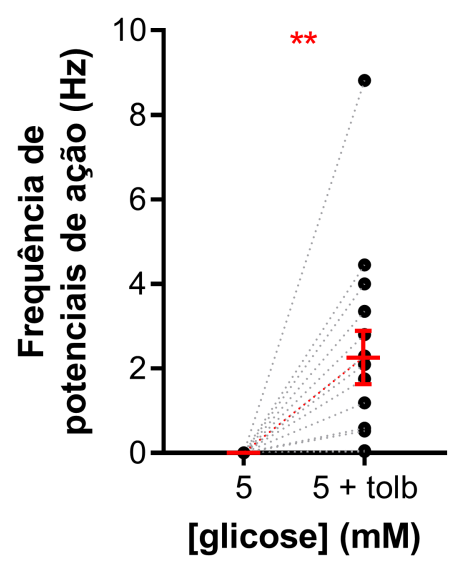

Figura 10. Grupo de neurônios do NTS responsivos à tolbutamida. A, registro representativo de um neurônio responsivo à tolbutamida. B, resumo do efeito da tolbutamida no potencial de membrana $\left(V_{m}\right)$ em neurônios responsivos. C, resumo do efeito da tolbutamida na frequência de potenciais de ação em neurônios responsivos. Tolb, tolbutamida. ${ }^{* *} p<0,01 ;{ }^{* * *} p<0,0001$.

Em outros cinco neurônios registrados (26,3\%), a aplicação de tolbutamida não alterou o potencial de membrana $(0,6 \pm 0,5 \mathrm{mV}$, de uma média de $-66,3 \pm 2,2$ $m V$ para $-65,7 \pm 1,9 \mathrm{mV} ; \mathrm{p}=0,28$; Figura 11A e 11B) nem a atividade elétrica $(0,1 \pm$ $0,1 \mathrm{~Hz}$, de uma média de $0,5 \pm 0,4 \mathrm{~Hz}$ para $0,6 \pm 0,6 \mathrm{~Hz} ; p=0,29$; Figura 11C). 


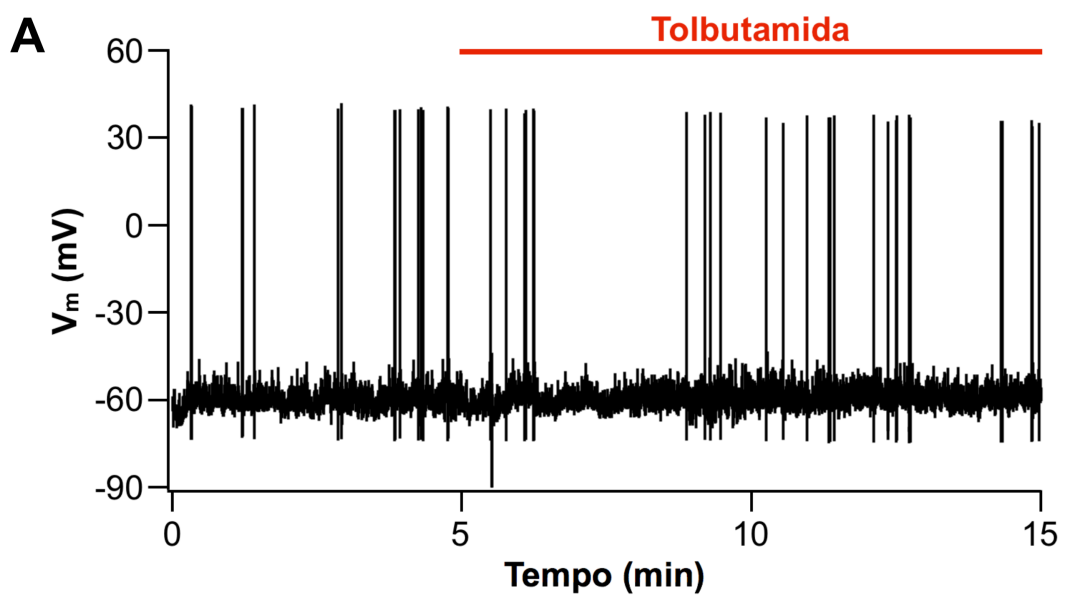

B

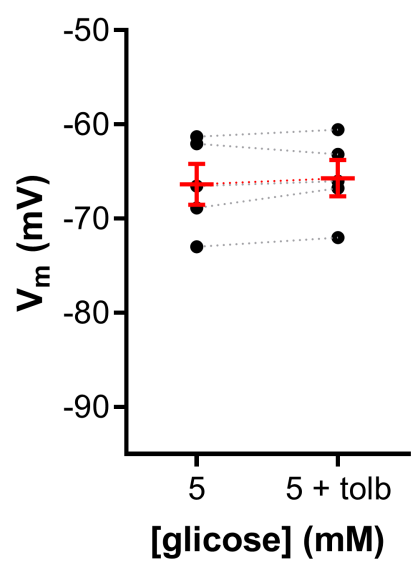

C

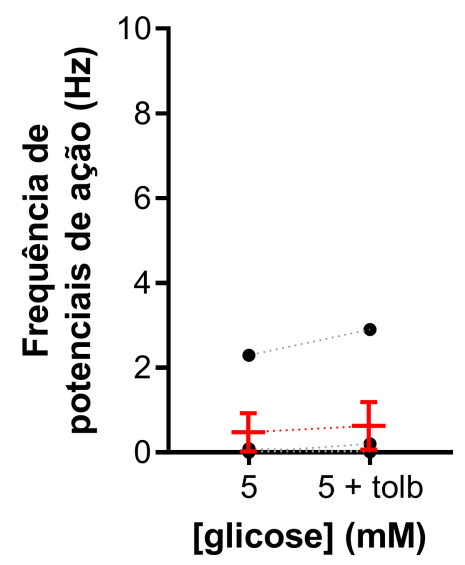

Figura 11. Grupo de neurônios do NTS não-responsivos à tolbutamida. A, registro representativo de um neurônio não-responsivo à tolbutamida. $\mathbf{B}$, resumo do efeito da tolbutamida no potencial de membrana $\left(V_{m}\right)$ em neurônios não-responsivos. C, resumo do efeito da tolbutamida na frequência de potenciais de ação em neurônios não-responsivos. Tolb, tolbutamida.

Observamos também que os neurônios não-responsivos à tolbutamida estavam com o potencial de repouso da membrana (RMP) mais despolarizado em comparação aos neurônios responsivos (-66,3 $\pm 2,0 \mathrm{mV}$ vs. $-75,7 \pm 2,4 \mathrm{mV}$, respectivamente; $p=0,02$; Figura 12A). Interessantemente, a despolarização induzida por tolbutamida possuiu correlação negativa com o RMP dos neurônios ( $r^{2}$ $=0,59 ; p=0,0001$; Figura 12B), ou seja, quanto mais negativo o RMP neuronal, maior a amplitude da resposta despolarizante à tolbutamida. 
A

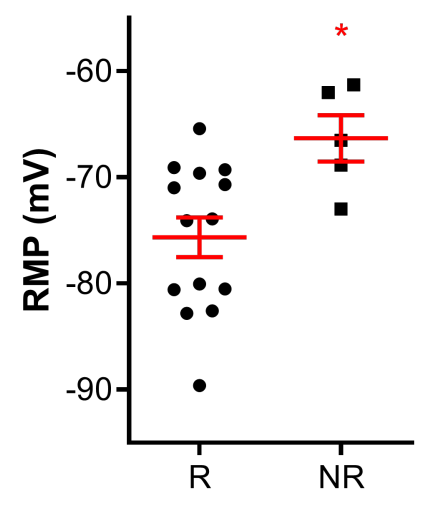

B

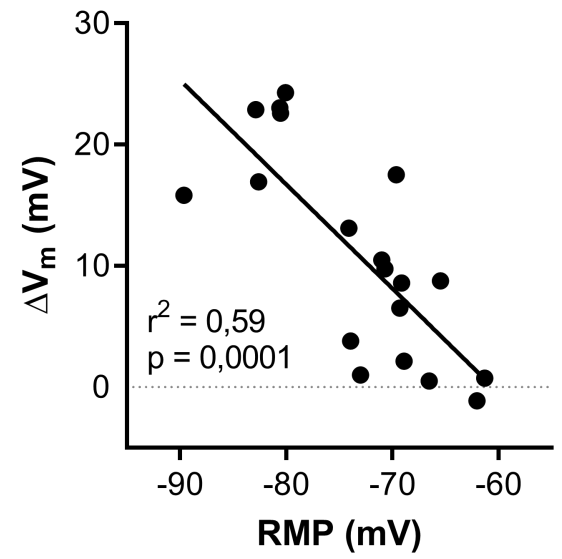

Figura 12. A despolarização induzida pelo fechamento dos canais $K_{A T P}$ é dependente do potencial de repouso da membrana em neurônios do NTS. A, comparação do potencial de repouso da membrana (RMP) entre neurônios responsivos $(\mathrm{R})$ e não-responsivos $(\mathrm{NR})$ à tolbutamida. $\mathrm{B}$, correlação linear entre a alteração do potencial de membrana $\left(\mathrm{V}_{\mathrm{m}}\right)$ induzida pela tolbutamida e o RMP em neurônios. ${ }^{*} p<0,05$.

Estes resultados indicam que os canais $\mathrm{K}_{\mathrm{ATP}}$ encontram-se ativos em neurônios do NTS, e que neurônios não-responsivos à tolbutamida possivelmente estejam com os canais $K_{\text {ATP }}$ fechados no repouso. Além disso, a inibição das correntes de potássio mediados pelos canais $\mathrm{K}_{\mathrm{ATP}}$ é suficiente para deflagrar potenciais de ação em neurônios do NTS.

Com o intuito de investigar o efeito da tolbutamida diretamente no neurônio do NTS sob registro, em uma segunda série de experimentos ( $n=15$, sete animais) aplicamos tolbutamida na presença de tetrodotoxina $(0,5 \mu \mathrm{M}$; TTX) para que a neurotransmissão dependente de potencial de ação seja inibida, o que minimiza a influência da circuitaria neuronal na avaliação da resposta em questão. Adicionalmente, monitoramos a resistência de entrada da membrana $\left(R_{\text {input }}\right)$ durante todo o registro eletrofisiológico a fim de analisar o efeito da tolbutamida em neurônios do NTS com maior precisão.

Nestas condições, observamos que em 10 neurônios (67\%) a aplicação de tolbutamida induziu uma rápida e forte despolarização $(16,7 \pm 2,7 \mathrm{mV}$, de uma média de $-76,1 \pm 2,6 \mathrm{mV}$ para $-59,4 \pm 1,2 \mathrm{mV} ; \mathrm{p}=0,0002$; Figuras 13A e 13B), acompanhada por um robusto aumento na $R_{\text {input }}(190,5 \pm 55,2 \mathrm{M} \Omega$, de uma média de $406,9 \pm 79,2 \mathrm{M} \Omega$ para $597,4 \pm 73,4 \mathrm{M} \Omega ; \mathrm{p}=0,007$; Figura 13C), o que está de acordo com o seu efeito bloqueador dos canais $\mathrm{K}_{\mathrm{ATP}}$. 

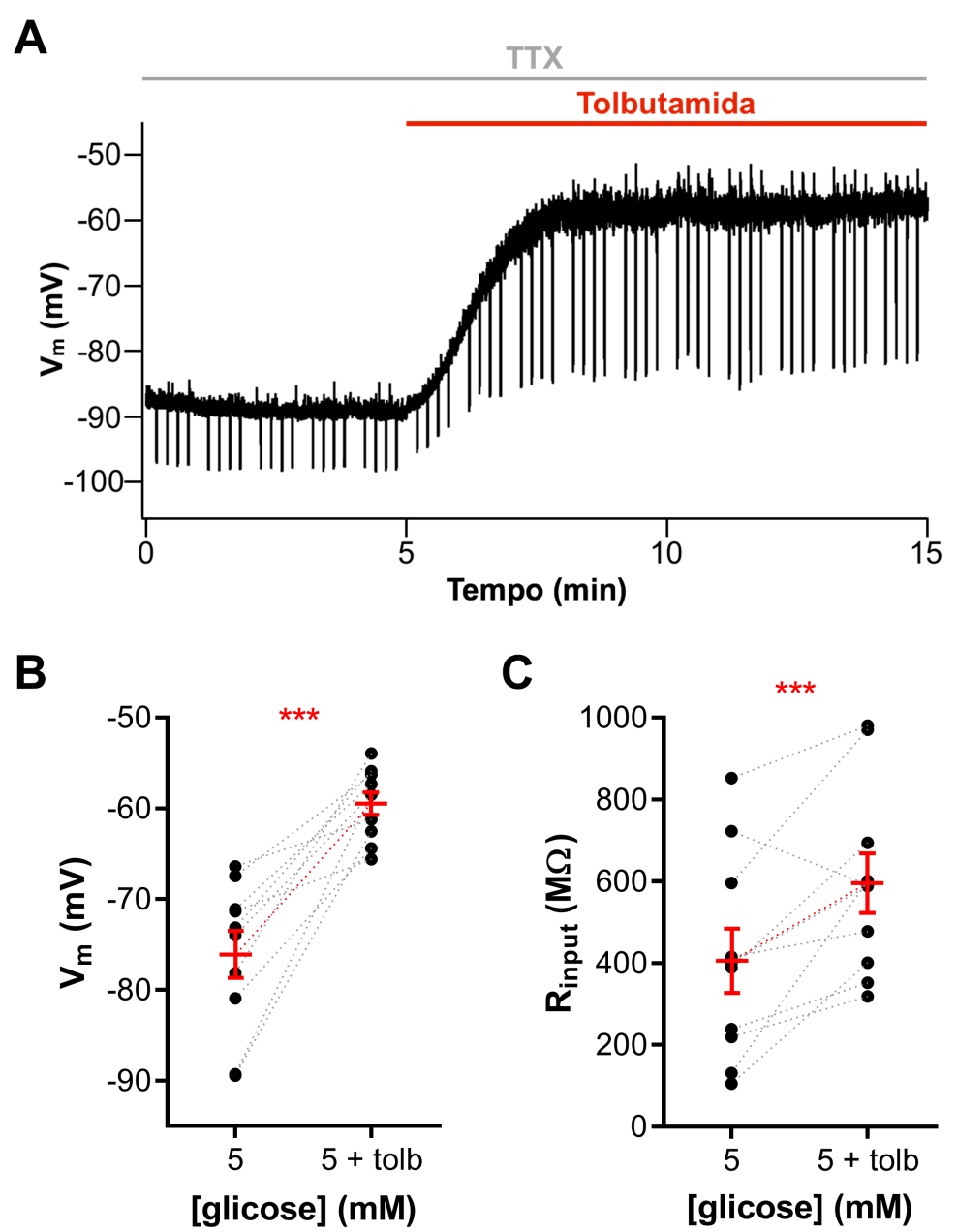

Figura 13. Grupo de neurônios do NTS responsivos à tolbutamida na presença de tetrodotoxina. A, registro representativo de um neurônio responsivo à tolbutamida na presença de tetrodotoxina (TTX). B, resumo do efeito da tolbutamida no potencial de membrana $\left(V_{m}\right)$ em neurônios responsivos. $\mathbf{C}$, resumo do efeito da tolbutamida na resistência de entrada da membrana ( $\left.R_{\text {input }}\right)$ em neurônios responsivos. Tolb, tolbutamida. ${ }^{* *} p<0,001$.

Adicionalmente, cinco neurônios (33\%) não tiveram o RMP alterado em resposta à tolbutamida $(1,0 \pm 0,5 \mathrm{mV}$, de uma média de $-65,1 \pm 2,4 \mathrm{mV}$ para $-64,1 \pm$ $2,2 \mathrm{mV} ; \mathrm{p}=0,1$; Figuras 14A e 14B), bem como a $\mathrm{R}_{\text {input }}$ permaneceu inalterada $(14,8 \pm 11,0 \mathrm{M} \Omega$, de uma média de 525,8 \pm 121,8 $\mathrm{M} \Omega$ para 540,6 \pm 129,1 $\mathrm{M} \Omega ; \mathrm{p}=$ 0,$2 ;$ Figura 14C). 


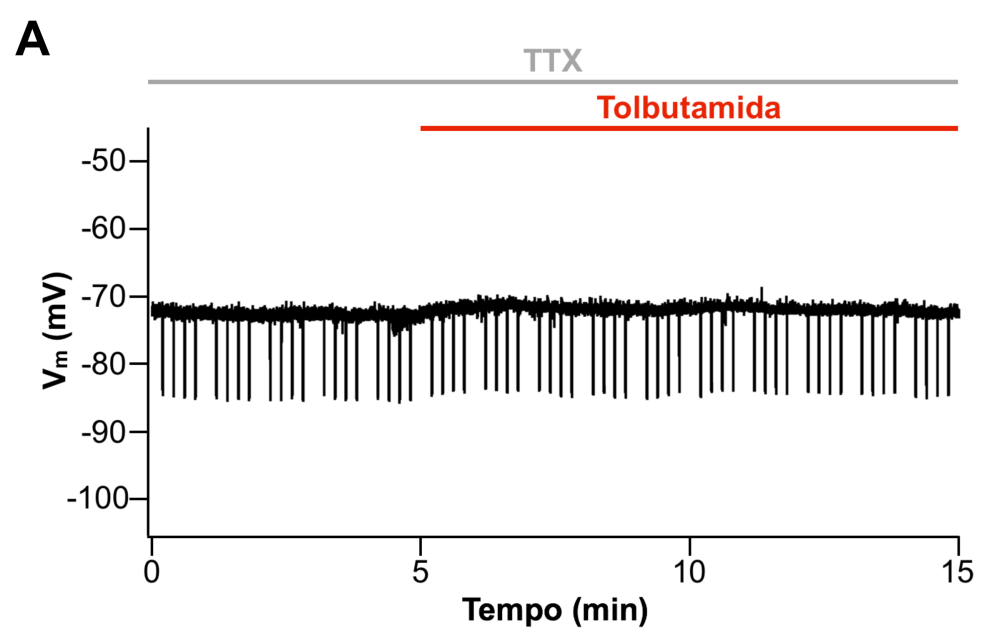

B

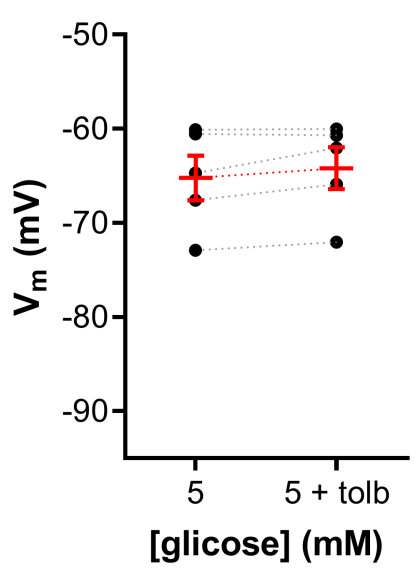

C

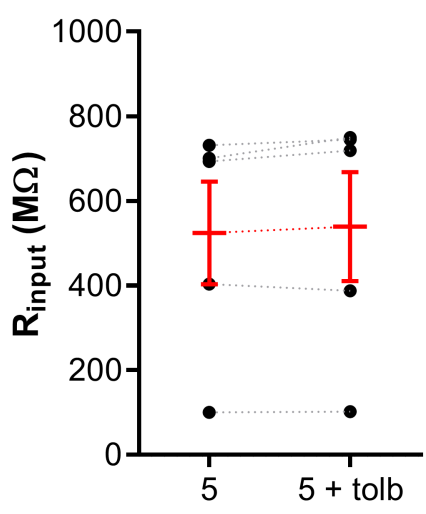

[glicose] (mM)

Figura 14. Grupo de neurônios do NTS não-responsivos à tolbutamida na presença de tetrodotoxina. A, registro representativo de um neurônio nãoresponsivo à tolbutamida na presença de tetrodotoxina (TTX). B, resumo do efeito da tolbutamida no potencial de membrana $\left(V_{m}\right)$ em neurônios não-responsivos. C, resumo do efeito da tolbutamida na resistência de entrada da membrana $\left(R_{\text {input }}\right)$ em neurônios não-responsivos. Tolb, tolbutamida.

Assim como observado nos experimentos sem a presença de TTX, verificamos que o RMP de neurônios não-responsivos à tolbutamida estava mais despolarizado em relação aos neurônios responsivos (-65,2 $\pm 2,4 \mathrm{mV}$ vs. $-76,1 \pm 2,5$ $m V$, respectivamente; $p=0,019$; Figura 15A). Adicionalmente, encontramos uma correlação negativa entre o RMP e a amplitude da despolarização induzida por tolbutamida ( $r^{2}=0,79 ; p<0,0001$; Figura 15B). Por outro lado, nenhuma correlação foi observada entre a alteração da $R_{\text {input }}$ induzida por tolbutamida $\left(\Delta R_{\text {input }}\right)$ e a $R_{\text {input }}$ basal $\left(r^{2}=0,2 ; p=0,2\right.$; Figura 15C). 
A

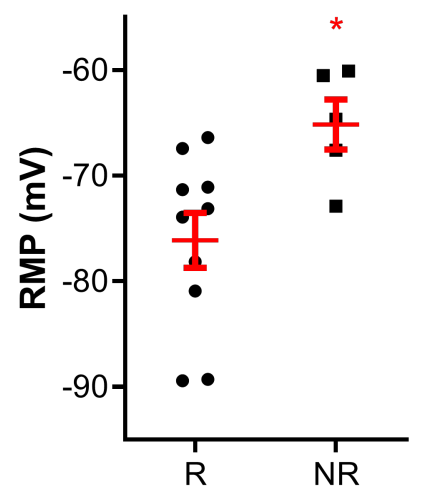

Subtipo neuronal
B

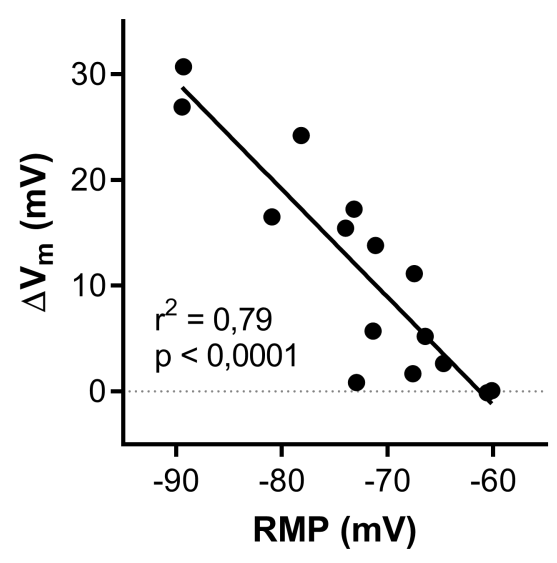

C

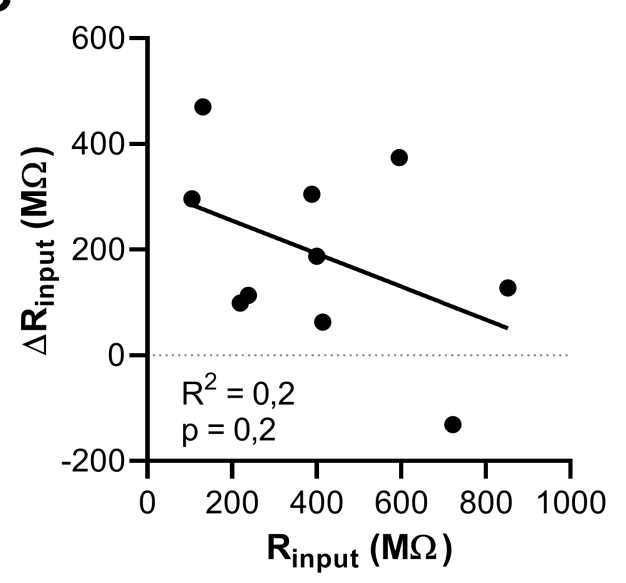

Figura 15. Neurônios do NTS possuem canais $K_{\text {ATP }}$ ativos no repouso. A, comparação do potencial de repouso da membrana (RMP) entre neurônios responsivos $(R)$ e não-responsivos $(N R)$ à tolbutamida. $B$, correlação linear entre a alteração do potencial de membrana $\left(\mathrm{V}_{\mathrm{m}}\right)$ induzida pela tolbutamida e o RMP em neurônios. C, correlação linear entre a alteração da resistência de entrada da membrana ( $\left.R_{\text {input }}\right)$ induzida pela tolbutamida e a $R_{\text {input }}$ basal em neurônios. ${ }^{*} p<0,05$.

Portanto, concluímos que neurônios do NTS apresentam canais $\mathrm{K}_{\mathrm{ATP}}$ ativos na membrana em condições normoglicêmicas, os quais podem controlar o RMP e a atividade elétrica. Devido ao fato de que neurônios não-responsivos à tolbutamida estavam com RMP mais despolarizado, é possível que os canais $K_{\text {ATP }}$ já encontravam-se fechados nesses neurônios.

\subsubsection{Efeito da abertura dos canais $K_{A T P}$ em neurônios do NTS}

Para determinar se neurônios não-responsivos à tolbutamida possuem canais $\mathrm{K}_{\text {ATP }}$ expressos na membrana, testamos o efeito do ativador dos canais $\mathrm{K}_{\text {ATP }}$ diazoxida $(200 \mu \mathrm{M})$ no RMP de neurônios do NTS na presença de TTX ( $n=7$, cinco animais). Verificamos que a perfusão de diazoxida induziu hiperpolarização rápida e 
parcialmente reversível em todos os neurônios registrados $(-8,8 \pm 2,1 \mathrm{mV}$, de uma média de $-73,7 \pm 1,7 \mathrm{mV}$ para $-82,6 \pm 3,3 \mathrm{mV} ; \mathrm{p}=0,005$; Figuras 16A e 16B). A aplicação de diazoxida também diminuiu a $R_{\text {input }}(-230,4 \pm 87,7 \mathrm{M} \Omega$, de uma média de 532,3 \pm 103,7 $\mathrm{M} \Omega$ para 301,9 \pm 65,3 M ; $p=0,04$; Figura 16C), o que está de acordo com o seu efeito em abrir canais $\mathrm{K}_{\mathrm{ATP}}$.
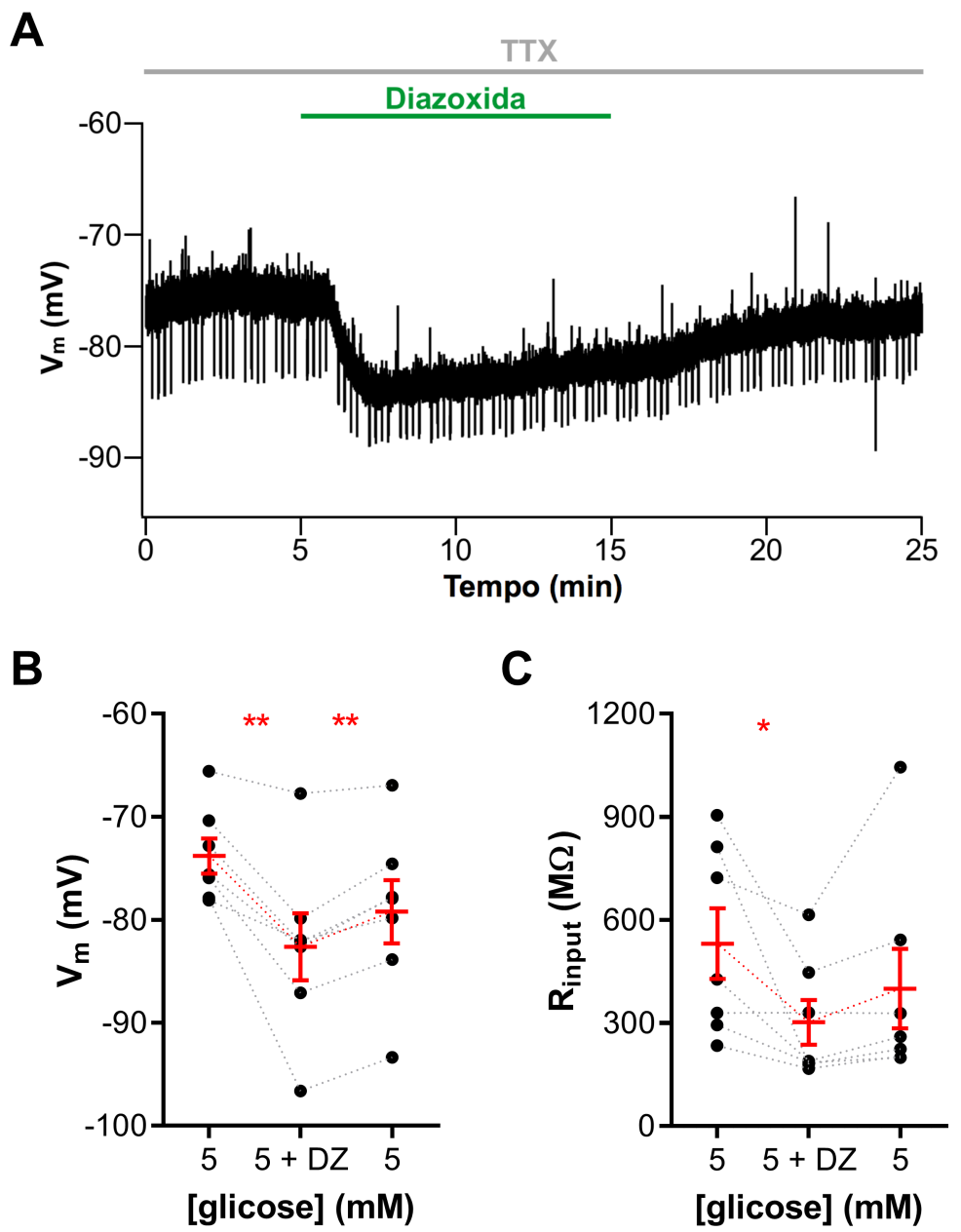

Figura 16. A modulação dos canais $K_{\text {ATP }}$ afeta o potencial de repouso da membrana em neurônios do NTS. A, registro representativo do efeito da aplicação de diazoxida em um neurônio na presença de tetrodotoxina (TTX). B, resumo do efeito da diazoxida no potencial de membrana $\left(V_{m}\right)$ em neurônios. $C$, resumo do efeito da diazoxida na resistência de entrada da membrana $\left(R_{\text {input }}\right)$ em neurônios. $D Z$, diazoxida. ${ }^{*} p<0,05 ;{ }^{* *} p<0,01$.

Diferentemente do efeito observado em resposta à aplicação de tolbutamida, o efeito da diazoxida foi observado independentemente do RMP neuronal, ou seja, tanto em neurônios com RMP mais despolarizados como em neurônios hiperpolarizados. De fato, não constatamos correlação entre o efeito da diazoxida no potencial de membrana e o $\operatorname{RMP}\left(r^{2}=0,24 ; p=0,2\right.$; Figura 17A). Entretanto, 
encontramos uma correlação positiva entre a alteração da $R_{\text {input }}$ induzida por diazoxida $\left(\Delta R_{\text {input }}\right)$ e a $R_{\text {input }}$ basal $\left(r^{2}=0,61 ; p=0,04\right.$; Figura 17B), o que sugere que a magnitude do efeito da diazoxida é afetada pela quantidade de canais $\mathrm{K}_{\mathrm{ATP}}$ bloqueados.

A

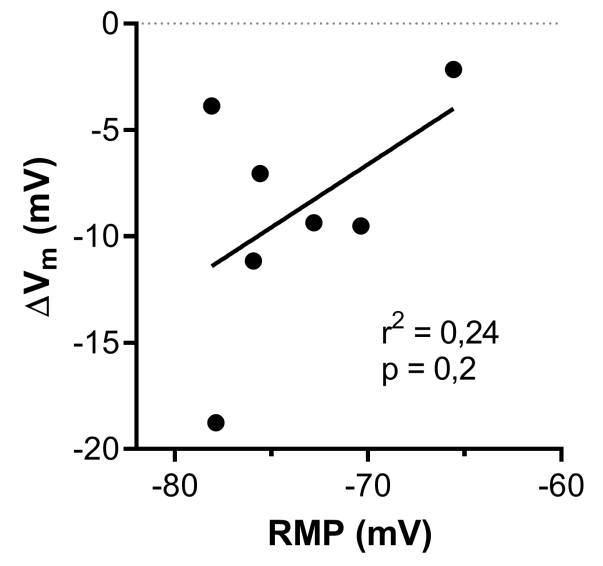

B

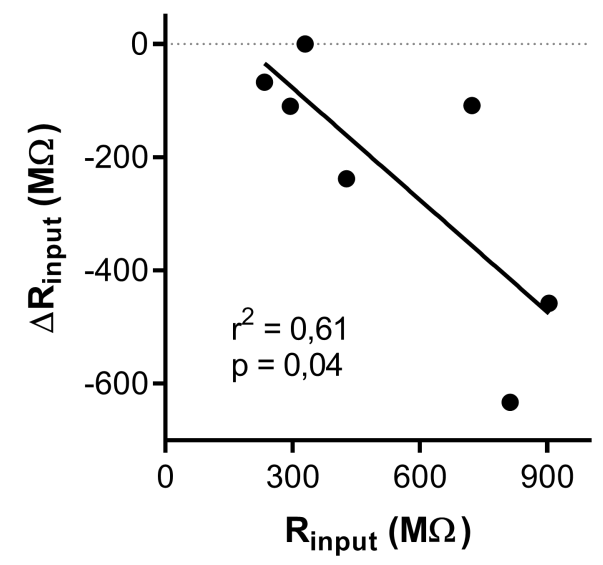

Figura 17. Os canais $K_{\text {ATP }}$ controlam o potencial de repouso da membrana em neurônios do NTS. A, correlação linear entre a alteração do potencial de membrana $\left(\mathrm{V}_{\mathrm{m}}\right)$ induzida pela diazoxida e o potencial de repouso da membrana (RMP) em neurônios. B, correlação linear entre a alteração da resistência de entrada da membrana ( $R_{\text {input }}$ ) induzida pela diazoxida e a $R_{\text {input }}$ basal em neurônios.

Portanto, devido à habilidade da diazoxida em abrir canais $\mathrm{K}_{\mathrm{ATP}}$ bloqueados, e pela ausência do efeito da tolbutamida em neurônios que possuem RMP mais despolarizado, concluímos que neurônios do NTS apresentam canais K KTP parcialmente abertos na membrana, e a modulação dos canais $\mathrm{K}_{\mathrm{ATP}}$ pode afetar o RMP bidirecionalmente.

\subsection{Sensibilidade à baixa glicose extracelular em neurônios do NTS}

4.2.1. Efeito da baixa glicose extracelular no potencial de membrana em neurônios do NTS

Neurônios do NTS participam de respostas contrarregulatórias à hipoglicemia (Lamy et al., 2014), e trabalhos recentes na literatura reportam que neurônios do NTS apresentam alterações no potencial de membrana em resposta a oscilações da glicose extracelular (Balfour et al., 2006; Boychuk et al., 2015). No presente estudo, nós mostramos que os canais $\mathrm{K}_{\text {ATP }}$ encontram-se parcialmente abertos em 
neurônios do NTS, portanto estando sujeitos à modulação da razão ATP/ADP metabólico.

Então, decidimos testar se uma condição de baixa glicose extracelular produziria hiperpolarização de neurônios do NTS pela ativação dos canais $\mathrm{K}_{\mathrm{ATP}}$, como consequência da redução da razão ATP/ADP citosólica. Para isso, perfundimos os neurônios do NTS incubados em 5 mM de glicose com uma solução contendo baixa glicose $(0,5 \mathrm{mM})$, uma concentração que pode ser atingida no fluido cerebroespinal durante períodos de hipoglicemia (Seaquist et al., 2001), e monitoramos o potencial de membrana e a frequência de disparos de potenciais de ação.

Surpreendentemente, observamos que a perfusão de neurônios do NTS ( $\mathrm{n}=$ 37, 23 animais) com uma solução de baixa glicose despolarizou a maioria dos neurônios (30 neurônios, $81 \%$ ) em 9,3 $\pm 1,0 \mathrm{mV}$, de uma média de -74,3 \pm 1,6 mV para $-65,0 \pm 1,7 \mathrm{mV}$ ( $p<0,0001$; Figura 18A e 18B). Este efeito levou em média 383 \pm 18 s para alcançar o pico de resposta, sendo reversível na maioria dos neurônios (70\%), e o RMP após o retorno para $5 \mathrm{mM}$ de glicose foi de $-71,3 \pm 1,9 \mathrm{mV}$ ( $\mathrm{p}<$ $0,0001)$.

A despolarização induzida por baixa glicose desencadeou o disparo de potenciais de ação em 16 de 28 neurônios silentes (57\%; 0,6 \pm 0,2 Hz; p = 0,007), e um aumento da frequência de potenciais de ação nos dois neurônios espontaneamente ativos (de uma média de $3,3 \pm 2,7 \mathrm{~Hz}$ para $8,4 \pm 2,0 \mathrm{~Hz}$ ). Apenas um neurônio (3\%) hiperpolarizou durante a perfusão de baixa glicose extracelular (7,9 $\mathrm{mV}$, de $-60,1$ para $-68,0 \mathrm{mV}$ ), sendo este efeito parcialmente reversível no reestabelecimento da solução inicial contendo $5 \mathrm{mM}$ de glicose. 

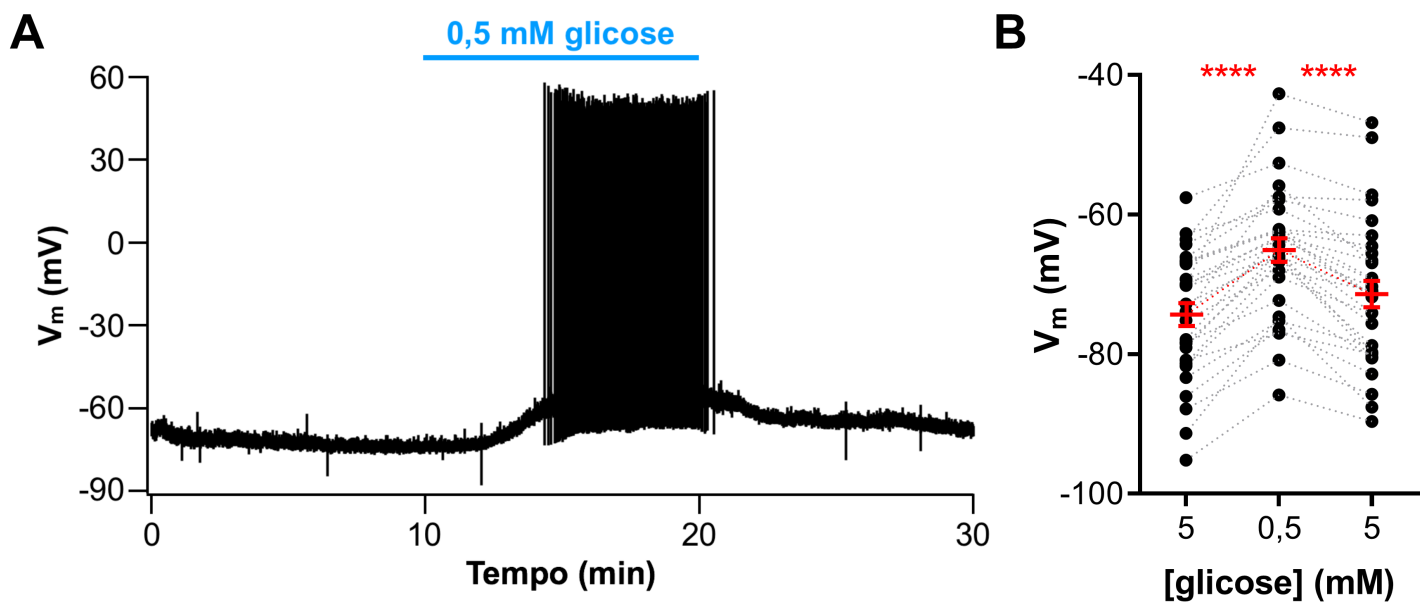

Figura 18. Grupo de neurônios do NTS responsivos à baixa glicose extracelular. A, registro representativo de um neurônio responsivo à baixa glicose. $B$, resumo do efeito da baixa glicose no potencial de membrana $\left(V_{m}\right)$ em neurônios responsivos. ${ }^{* * * *} p<0,0001$.

Por fim, seis neurônios (16\%) não responderam à baixa glicose $(1,0 \pm 0,7 \mathrm{mV}$, de uma média de RMP de $-64,1 \pm 2,0 \mathrm{mV}$ para $-63,1 \pm 1,6 \mathrm{mV} ; \mathrm{p}=0,2$; Figura 19A e 19B).

A

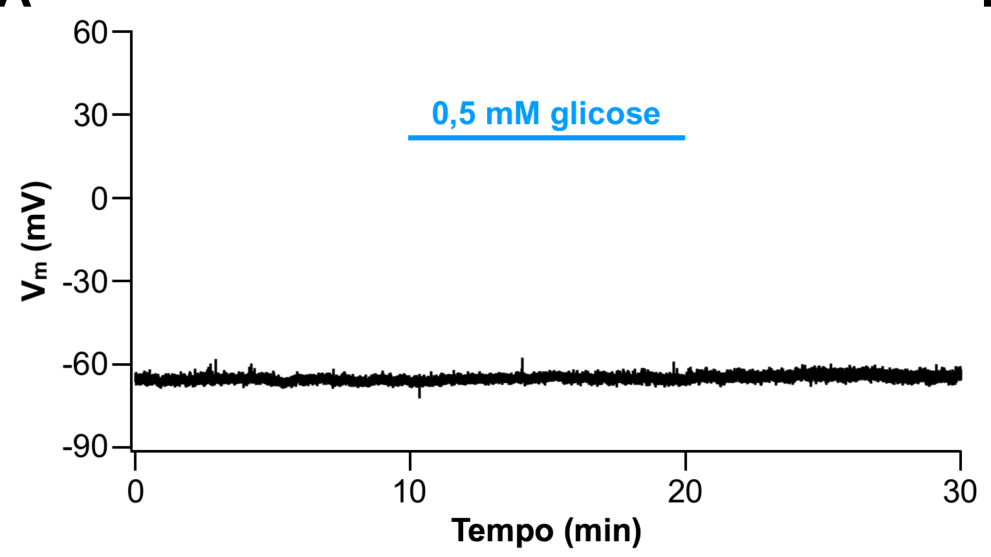

B

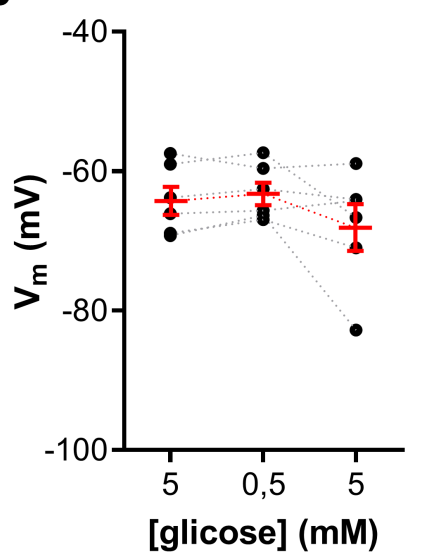

Figura 19. Grupo de neurônios do NTS não-responsivos à baixa glicose extracelular. A, registro representativo de um neurônio não-responsivo à baixa glicose. B, resumo do efeito da baixa glicose no potencial de membrana $\left(V_{m}\right)$ em neurônios.

Para testar a dependência da ativação de canais de sódio dependentes de voltagem para a sensibilidade à baixa glicose extracelular, e consequentemente avaliar a dependência da neurotransmissão dependente de potencial de ação, 
realizamos o desafio da baixa glicose em um segundo grupo de neurônios do NTS na presença de TTX ( $\mathrm{n}=23$ neurônios, 11 animais).

Novamente, identificamos três tipos de resposta. Catorze neurônios (61\%) foram despolarizados durante a perfusão da solução contendo baixa glicose em 8,8 $\pm 1,0 \mathrm{mV}$, de uma média de $-79,1 \pm 1,6 \mathrm{mV}$ para $-70,3 \pm 1,3 \mathrm{mV}(\mathrm{p}<0,0001$; Figuras 20A e 20B), e levaram em média $348 \pm 18$ s para o pico da resposta. Este efeito foi reversível na maioria dos neurônios (71\%), e o RMP após o retorno para $5 \mathrm{mM}$ de glicose foi de $-77,0 \pm 1,8 \mathrm{mV}(p<0,0001)$. Apenas um neurônio (4\%) hiperpolarizou em baixa glicose extracelular $(-5,5 \mathrm{mV}$, de $-72,1 \mathrm{mV}$ para $-77,6 \mathrm{mV})$, sendo este efeito reversível após o retorno à solução inicial de $5 \mathrm{mM}$ de glicose.

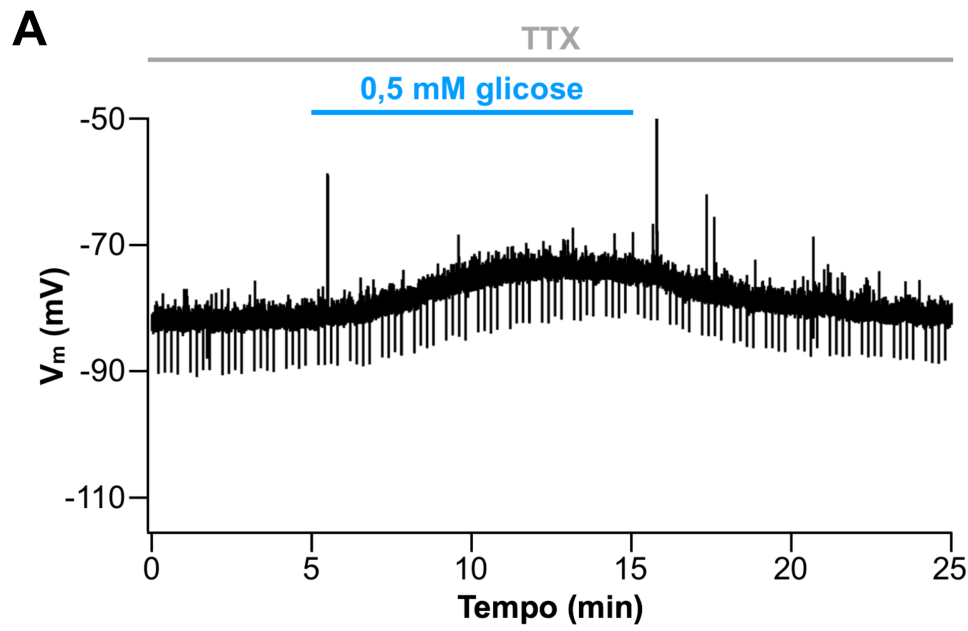

B

C
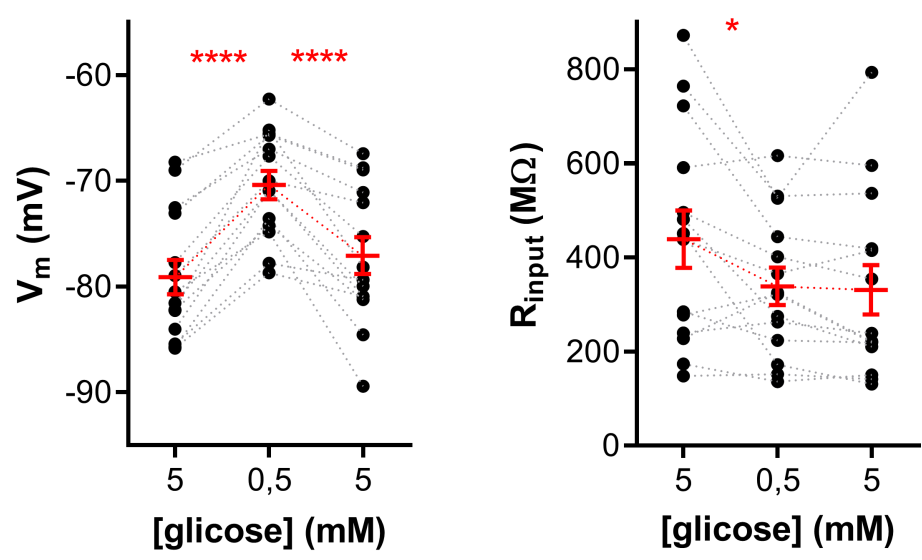

Figura 20. Grupo de neurônios do NTS responsivos à baixa glicose extracelular na presença de tetrodotoxina. A, registro representativo de um neurônio responsivo à baixa glicose na presença de tetrodotoxina (TTX). B, resumo do efeito da baixa glicose no potencial de membrana $\left(V_{m}\right)$ em neurônios. $C$, resumo do efeito da baixa glicose na resistência de entrada da membrana ( $\left.R_{\text {input }}\right)$ em neurônios. ${ }^{*} p<0,05 ;{ }^{* * *} p<0,0001$. 
Por fim, oito neurônios (35\%) foram considerados não-responsivos à baixa glicose $(1,1 \pm 0,5 \mathrm{mV}$, de uma média de RMP de $-66,9 \pm 1,6 \mathrm{mV}$ para $-65,8 \pm 1,7$ $\mathrm{mV} ; \mathrm{p}=0,07$; Figuras 21A e 21B).

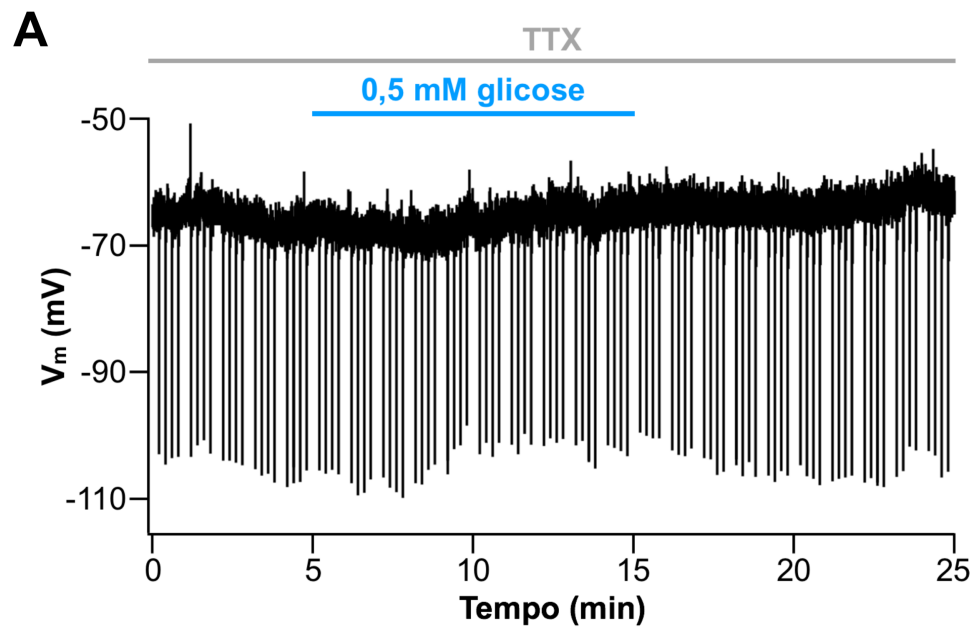

B

C
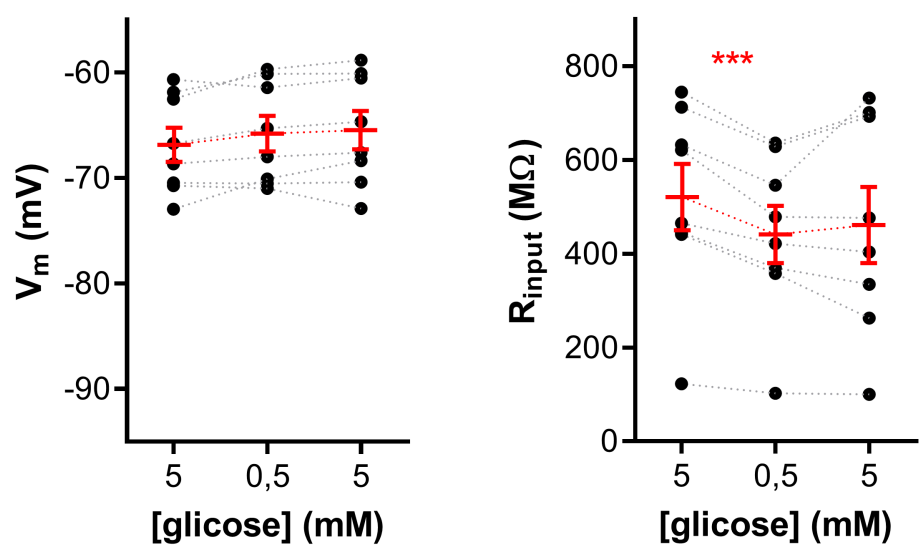

Figura 21. Grupo de neurônios do NTS não-responsivos à baixa glicose extracelular na presença de tetrodotoxina. A, registro representativo de um neurônio não-responsivo à baixa glicose na presença de tetrodotoxina (TTX). B, resumo do efeito da baixa glicose no potencial de membrana $\left(V_{m}\right)$ em neurônios. C, resumo do efeito da baixa glicose na resistência de entrada da membrana $\left(R_{\text {input }}\right)$ em neurônios. ${ }^{* * *} p<0,001$.

O efeito despolarizante e a latência para o pico de resposta à baixa glicose não foram diferentes em neurônios registrados com ou sem $\operatorname{TTX~(~} p=0,7$ e $p=0,2$, respectivamente), e assim como observado nos experimentos conduzidos sem TTX, a maioria dos neurônios despolarizaram quando expostos à baixa glicose $(84 \% \mathrm{em}$ aCSF sem TTX vs. $65 \%$ em aCSF com TTX).

Portanto, concluímos que a resposta despolarizante induzida pela baixa glicose extracelular em neurônios do NTS não depende da neurotransmissão 
dependente de potencial de ação e, portanto, da ativação da circuitaria neuronal. A grande maioria dos experimentos descritos daqui em diante foram realizados na presença de TTX.

4.2.2. Efeito da baixa glicose extracelular na resistência de entrada da membrana em neurônios do NTS

Lamy et al. (2014) mostraram que a despolarização da membrana induzida por baixa glicose em neurônios GABAérgicos do NTS de camundongos foi acompanhada por um aumento na $\mathrm{R}_{\text {input }}$ causada pela inibição de uma condutância para potássio. Ao contrário desta observação, nós verificamos que neurônios do NTS de ratos diminuíram a $R_{\text {input }}(-101,1 \pm 37,8 \mathrm{M} \Omega$, de uma média de 440,3 $\pm 61,6$ $\mathrm{M} \Omega$ para $339,2 \pm 40 \mathrm{M} \Omega$; Figura 20C) quando expostos à baixa glicose extracelular. Diferentemente do observado no potencial de membrana, estes efeitos não reverteram após o retorno para a solução inicial contendo $5 \mathrm{mM}$ de glicose $(p=0,7)$.

Adicionalmente, neurônios não-responsivos à baixa glicose também mostraram uma diminuição na $R_{\text {input }}(-80,3 \pm 13,2 \mathrm{M} \Omega$, de uma média de $522,9 \pm$ 71,1 M $\Omega$ para 442,6 \pm 61,6 M $\Omega ; p=0.0005$; Figura 21C). Assim como em neurônios responsivos à baixa glicose, o $\mathrm{R}_{\text {input }}$ dos neurônios não-responsivos não reverteu após o reestabelecimento da solução inicial de $5 \mathrm{mM}$ de glicose $(p=0,5)$. Interessantemente, o único neurônio que hiperpolarizou em resposta à baixa glicose na presença de TTX apresentou uma diminuição robusta da $R_{\text {input }}(629,2 \mathrm{M} \Omega$, de $900,5 \mathrm{M} \Omega$ para $271,3 \mathrm{M} \Omega$ ), o que sugere a abertura de canais $\mathrm{K}_{\mathrm{ATP}}$.

Nós também observamos que a despolarização induzida por baixa glicose foi negativamente correlacionada com o RMP neuronal $\left(r^{2}=0,53\right.$; $p<0,0001$; Figura 22A), onde o RMP de neurônios não-responsivos à baixa glicose estava mais despolarizado em comparação aos neurônios responsivos (-66,8 \pm 1,6 mV vs. -78,6 $\pm 1,6 \mathrm{mV}$, respectivamente; $p=0,0001$; Figura 22C. Além disso, constatamos uma pequena correlação negativa entre o efeito da baixa glicose na amplitude de despolarização da membrana $\left(\Delta \mathrm{V}_{\mathrm{m}}\right)$ e $\Delta \mathrm{R}_{\text {input }}\left(r^{2}=0,18 ; p=0,04\right.$; Figura 22B $)$. 
A

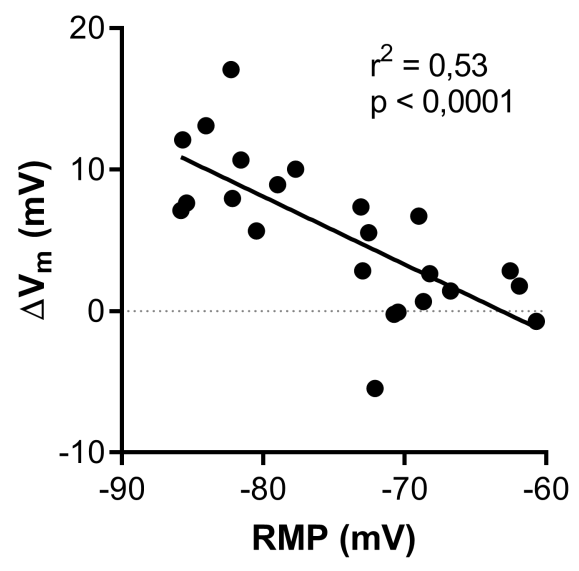

C

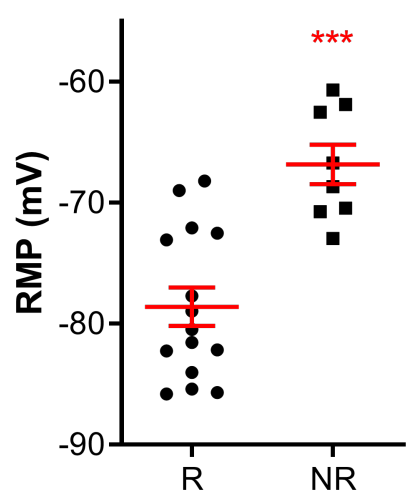

B

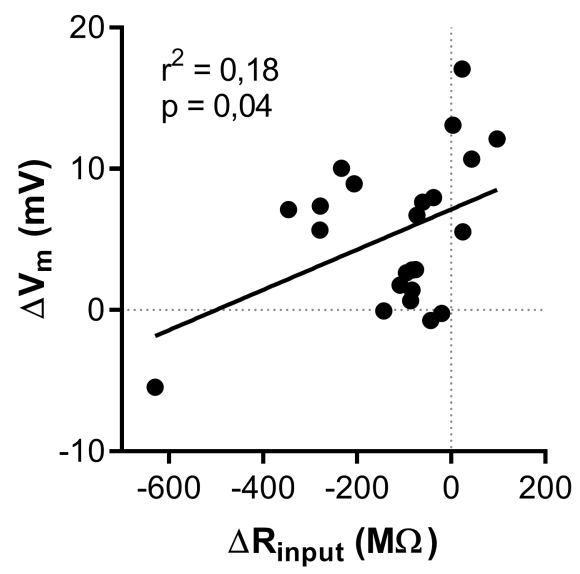

Figura 22. A baixa glicose extracelular induz um mecanismo de resposta dependente de voltagem em neurônios do NTS. A, correlação linear entre a alteração do potencial de membrana $\left(V_{\mathrm{m}}\right)$ induzida pela baixa glicose e o potencial de repouso da membrana (RMP) em neurônios. $\mathbf{B}$, correlação linear entre as alterações de $V_{m}$ e resistência de entrada da membrana ( $R_{\text {input }}$ ) induzidas pela baixa glicose em neurônios. C, comparação do RMP entre neurônios responsivos (R) e não-responsivos (NR) à baixa glicose. ${ }^{* * *} p<0,001$.

Em conjunto, concluímos que neurônios do NTS respondem à baixa glicose extracelular por um mecanismo de despolarização dependente de voltagem, o qual deve envolver a abertura de uma condutância de membrana catiônica.

4.2.3. Efeito do aumento da concentração da glicose interna na sensibilidade à baixa glicose extracelular em neurônios do NTS

Nossos resultados mostram que a sensibilidade à baixa glicose extracelular em neurônios do NTS não depende da ativação da circuitaria neuronal. Por outro lado, a participação de células gliais na regulação da homeostase da glicose tem sido destacada (García-Cáceres et al., 2019). A ativação de astrócitos pode levar à 
liberação de moléculas sinalizadoras, i.e., gliotransmissores, que modulam a excitabilidade neuronal (Araque et al., 2014), e astrócitos do NTS podem ser ativados pela baixa glicose extracelular (McDougal et al., 2013).

Portanto, a fim de determinar se células gliais, ou mesmo neurônios vizinhos, poderiam modular a sensibilidade à baixa glicose extracelular em neurônios do NTS, nós adicionamos $3 \mathrm{mM}$ de glicose na pipeta de registro e medimos a resposta do neurônio à baixa glicose na presença de $\operatorname{TTX}(\mathrm{n}=6$, quatro animais). Nestas condições, a perfusão com solução contendo baixa glicose não alterou o RMP dos neurônios do NTS $(-1,0 \pm 0,64 \mathrm{mV}$, de uma média de $-76,3 \pm 3,6 \mathrm{mV}$ para $-75,3 \pm 3,2$ $\mathrm{mV} ; \mathrm{p}=0,2$; Figura 23A), o que sugere que a diminuição da baixa glicose extracelular é detectada pelo neurônio sob registro. Curiosamente, estes neurônios apresentaram uma pequena diminuição na $R_{\text {input }}(-39,9 \pm 15,4 \mathrm{M} \Omega$, de uma média de $352,7 \pm 58,7 \mathrm{M} \Omega$ para 312,8 $\pm 64,1 \mathrm{M} \Omega(\mathrm{p}=0,046)$. Estes dados estão de acordo com o observado previamente por Lamy et al. (2014), que também não observaram despolarização do potencial de membrana induzida pela baixa glicose extracelular em neurônios do NTS registrados com solução de pipeta contendo glicose adicional.

A

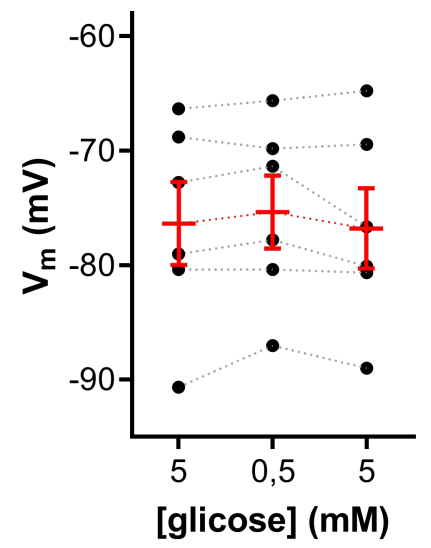

B

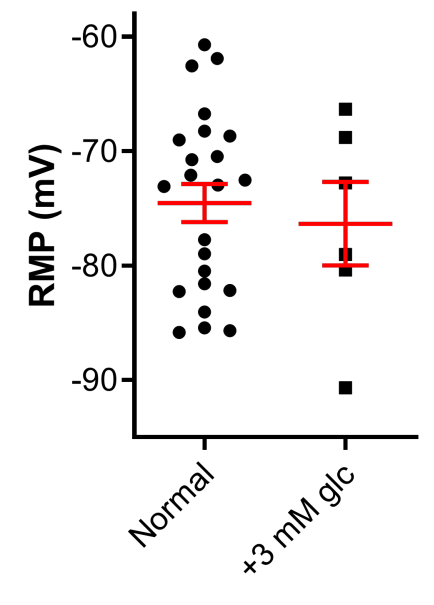

Solução da pipeta
C

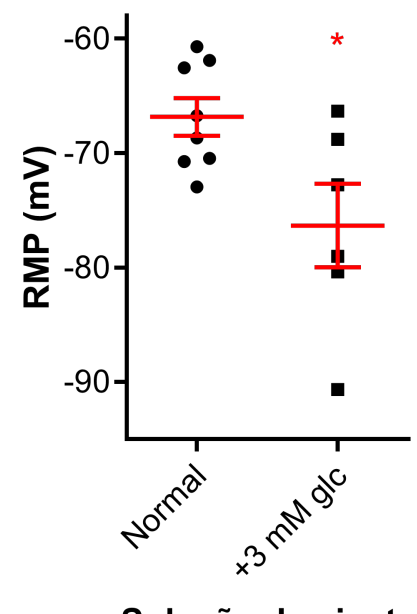

Solução da pipeta

Figura 23. A presença de glicose na pipeta de registro inibe a deteç̧ão da baixa glicose extracelular por neurônios do NTS. A, resumo do efeito da baixa glicose no potencial de membrana $\left(V_{m}\right)$ em neurônios registrados com solução de pipeta contendo $3 \mathrm{mM}$ de glicose. B, comparação do potencial de repouso da membrana (RMP) entre neurônios registrados com solução de pipeta normal e solução de pipeta contendo $3 \mathrm{mM}$ de glicose. C, comparação do RMP entre neurônios não-responsivos à baixa glicose registrados com solução de pipeta normal e neurônios registrados com solução de pipeta contendo $3 \mathrm{mM}$ de glicose. ${ }^{*} p<0,05$. 
O RMP dos neurônios registrados com $3 \mathrm{mM}$ de glicose na pipeta não foi diferente do RMP dos neurônios registrados com a solução de pipeta regular ( $p=$ 0,6; Figura 23B), assim como não houve diferença entre os valores de $R_{\text {input }}(p=$ 0.18). Estes resultados mostram que a presença de glicose na pipeta não despolariza o neurônio, o que poderia influenciar na sensibilidade à baixa glicose extracelular, já que se trata de um mecanismo dependente de voltagem. De fato, o RMP de neurônios não-responsivos à baixa glicose registrados com uma solução de pipeta normal (os quais apresentam RMP mais positivo quando comparados ao neurônios responsivos; Figura 22C) está mais despolarizado em comparação ao RMP dos neurônios registrados com 3 mM de glicose na pipeta (-66,8 \pm 1,6 mV vs. $76,3 \pm 3,6 \mathrm{mV}$, respectivamente; $p=0,02$; Figura 23C).

Em conjunto, estes dados sugerem o estado metabólico dos neurônios do NTS é suficiente para modular a sensibilidade à glicose extracelular. Entretanto, a influência de células gliais neste mecanismo não pode ser descartada. Adiante (seção 4.3.), a sensibilidade à baixa glicose extracelular em astrócitos do NTS, bem como a gliotransmissão, será melhor descrita.

4.2.4. Influência da idade dos animais na resposta à baixa glicose extracelular e à tolbutamida em neurônios do NTS

$\mathrm{Na}$ presente investigação, a maioria dos experimentos de desafio à baixa glicose foi realizada em animais de 3 semanas de idade; entretanto, utilizamos também animais com 6 e 11 semanas de idade. Então, decidimos verificar se a idade dos animais poderia influenciar na sensibilidade à glicose extracelular em neurônios do NTS.

Em animais com 3 semanas de idade ( $n=35$ neurônios), a maioria dos neurônios $(\mathrm{n}=27 ; 77 \%)$ despolarizou frente à baixa glicose extracelular $(8,4 \mathrm{mV} \pm$ $0,7 \mathrm{mV}$, de uma média de $-77,3 \pm 1,5 \mathrm{mV}$ para $-68,7 \pm 1,2 \mathrm{mV}$; $\mathrm{p}<0,0001$; Figura 24Ai), enquanto apenas um neurônio (3\%) hiperpolarizou durante a perfusão da solução contendo baixa glicose $(-5,5 \mathrm{mV}$, de uma média de $-72,1 \mathrm{mV}$ para $-77,6 \mathrm{mV})$. Outros sete neurônios (20\%) foram considerados não-responsivos $(1,5 \pm 0,5 \mathrm{mV}$, de $-66,6 \pm 2,0 \mathrm{mV}$ para $-65,1 \pm 2,1 \mathrm{mV} ; \mathrm{p}=0,2$; Figura 24Aii) à baixa glicose. Em animais com 6 semanas de idade ( $n=13$ neurônios), a maioria dos neurônios ( $\mathrm{n}=$ $11 ; 85 \%)$ despolarizou o potencial de membrana em baixa glicose $(11,4 \pm 2,1 \mathrm{mV}$, de uma média de 75,6 $\pm 2,1 \mathrm{mV}$ para $-64,2 \pm 3,3 \mathrm{mV} ; \mathrm{p}=0,0003$; Figura 24Bi), e dois 
neurônios (15\%) não responderam à baixa glicose $(2,0 \pm 0,8 \mathrm{mV}$, de uma média de $66,5 \pm 2,7 \mathrm{mV}$ para $-64,5 \pm 1,9 \mathrm{mV} ; \mathrm{p}=0$,2; Figura 24Bii). Em animais com 11 semanas de idade ( $n=12$ neurônios), seis neurônios (54\%) despolarizaram em solução de baixa glicose extracelular $(8,5 \pm 1,8 \mathrm{mV}$, de uma média de -70,6 $\pm 3,4 \mathrm{mV}$ para $-62,1 \pm 3,9 \mathrm{mV} ; \mathrm{p}=0,005$; Figura 24C $i$ ), enquanto um neurônio (8\%) hiperpolarizou (-7,9 mV, de -60,1 para $-68,0 \mathrm{mV})$. Outros cinco neurônios (38\%) não responderam à baixa glicose $(-0,1 \pm 0,6 \mathrm{mV}$, de uma média de $-63,9 \pm 2,1 \mathrm{mV}$ para $64,0 \pm 1,5 \mathrm{mV} ; \mathrm{p}=0$,9; Figura 24C $i i)$. 
Responsivos

A

B

C

\section{6 semanas de idade}

3 semanas de idade

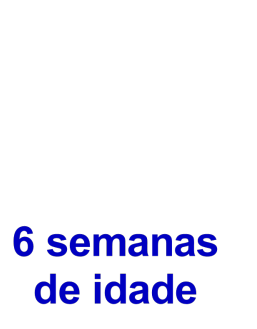

11 semanas de idade i

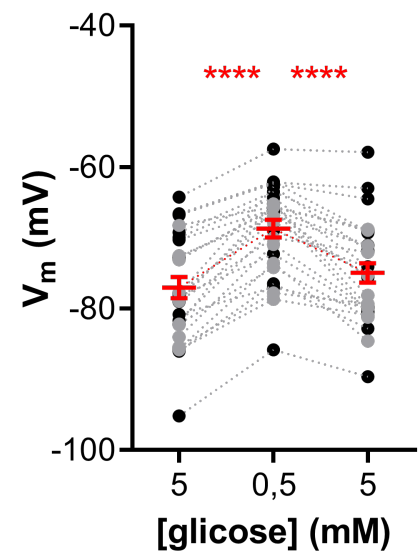

i

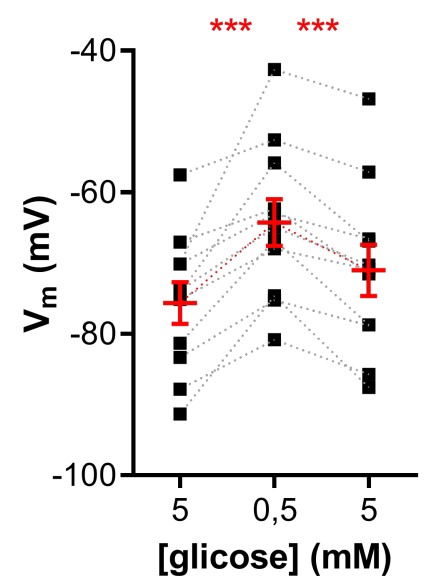

i

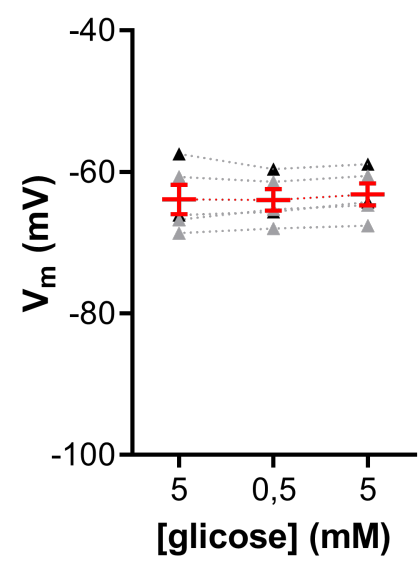

Não-responsivos

ii
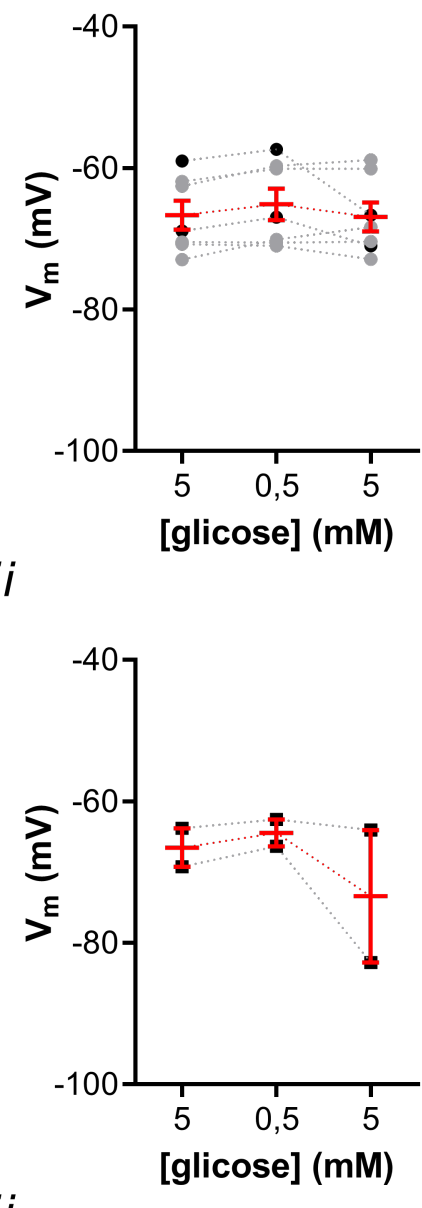

ii

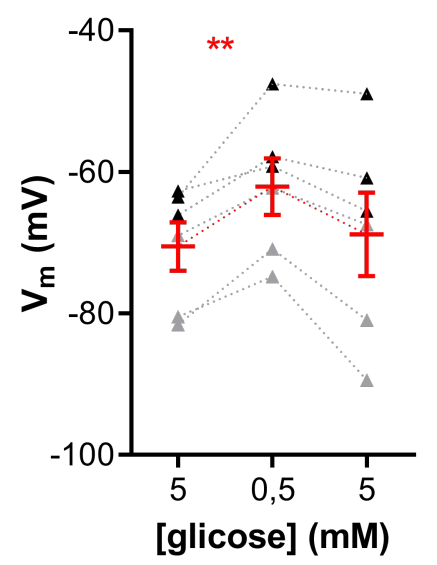

Figura 24. Influência da idade na alteração do potencial de membrana induzida pela baixa glicose extracelular em neurônios do NTS. A, resumo do efeito induzido pela baixa glicose no potencial de membrana $\left(V_{m}\right)$ em neurônios responsivos (Ai) e não-responsivos (Aii) de animais com 3 semanas de idade. $\mathbf{B}$, resumo do efeito induzido pela baixa glicose no $V_{m}$ em neurônios responsivos $(B i)$ e não-responsivos (Bii) de animais com 6 semanas de idade. C, resumo do efeito induzido pela baixa glicose no $V_{m}$ em neurônios responsivos $(\mathbf{C} i)$ e não-responsivos (Cii) de animais com 11 semanas de idade. Em todas as figuras, os pontos e 
traçados pretos indicam neurônios registrados com solução aCSF, enquanto os pontos e traçados cinzas indicam neurônios registrados com solução aCSF na presença de tetrodotoxina. ${ }^{*} p<0,05 ;{ }^{* * *} p<0,001 ;{ }^{* * * *} p<0,0001$.

Nós observamos que a magnitude da despolarização induzida por baixa glicose em neurônios responsivos foi similar em fatias provenientes de ratos com 3 , 6 e 11 semanas de idade (3 semanas: $8,4 \pm 0,7 \mathrm{mV} ; 6$ semanas $11,4 \pm 2,1 \mathrm{mV} ; 11$ semanas: $8,5 \pm 1,8 \mathrm{mV}(\mathrm{n}=6)$, respectivamente; $p=0,22$; Figura 25B]. Entretanto, verificamos maior proporção de neurônios não-responsivos em fatias de ratos com 11 semanas em comparação a ratos com 3 semanas (42\% vs. $20 \%$, respectivamente; $p=0,001)$ e 6 semanas de idade (15\%; $p<0,001$; Figura 25C). De acordo, o RMP dos ratos com 11 semanas de idade estava mais despolarizado quando comparado aos ratos com 3 e 6 semanas de idade ( 3 semanas: $-74,8 \pm 1,4$ $\mathrm{mV}$; 6 semanas: $-74,6 \pm 2,7 \mathrm{mV} ; 11$ semanas: $-66,9 \pm 2,1 \mathrm{mV} ; 3$ semanas vs. 6 semanas: $p=0,8 ; 3$ semanas vs. 11 semanas: $p=0,007 ; 6$ semanas vs. 11 semanas: $p=0,03$; Figura 25A].

A

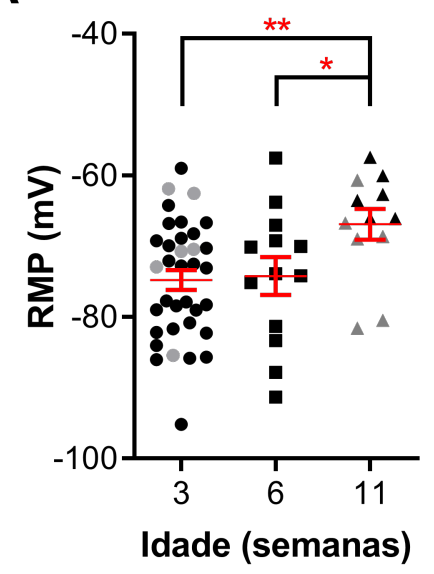

C

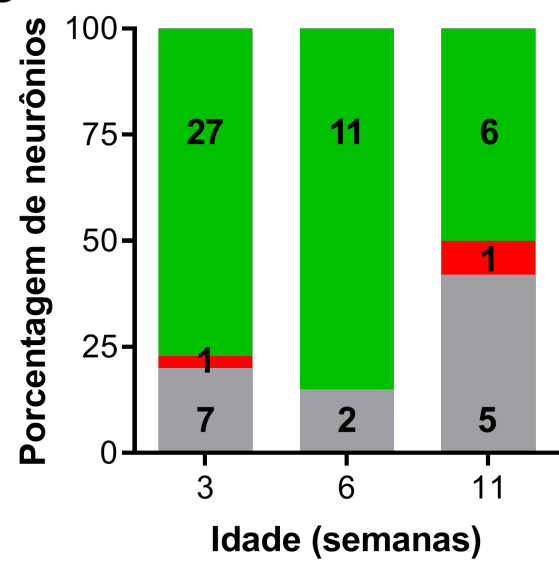

B

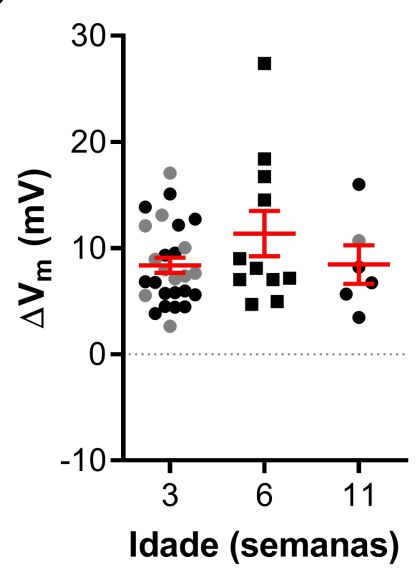

Ativados por baixa glicose

Inibidos por baixa glicose

Não-responsivos à baixa glicose 
Figura 25. Animais na fase adulta apresentam menor proporção de neurônios do NTS sensíveis à baixa glicose extracelular em comparação a animais mais jovens. A, comparação do potencial de repouso da membrana (RMP) entre neurônios de animais com 3, 6 e 11 semanas de idade. $\mathbf{B}$, comparação da alteração do potencial de membrana $\left(\mathrm{V}_{\mathrm{m}}\right)$ induzida pela baixa glicose entre neurônios de animais com 3, 6 e 11 semanas de idade. C, comparação da distribuição dos neurônios de acordo com a resposta induzida pela baixa glicose em animais com 3 , 6 e 11 semanas de idade. ${ }^{*} p<0,05 ;{ }^{* *} p<0,01$.

Devido ao efeito da tolbutamida também ser dependente de voltagem, nós verificamos a relação entre a sensibilidade à tolbutamida e a idade dos animais (3 semanas e 6 semanas). Em animais com 3 semanas de idade ( $n=15$ neurônios), a aplicação de tolbutamida despolarizou a maioria dos neurônios ( $n=13,87 \%$ ) em $14,6 \pm 2,1 \mathrm{mV}$, de uma média de $-75,2 \pm 2,0 \mathrm{mV}$ para $-60,6 \pm 1,4 \mathrm{mV} ; \mathrm{p}<0,0001$ Figura 26Ai), enquanto apenas dois neurônios (13\%) foram considerados nãoresponsivos $(0,5 \pm 0,4 \mathrm{mV}$, de uma média de $-66,5 \pm 6,4 \mathrm{mV}$ para $-66,0 \pm 6,0 \mathrm{mV}$; Figura 26Aii). Em animais com 11 semanas de idades ( $n=19$ neurônios), 11 neurônios $(58 \%)$ responderam à tolbutamida com despolarização $(16,5 \pm 2,2 \mathrm{mV}$, de uma média de $-76,7 \pm 2,3 \mathrm{mV}$ para $-60,2 \pm 1,6 \mathrm{mV} ; \mathrm{p}<0,0001$; Figura 26Bi), e oito neurônios (42\%) não mostraram um efeito responsivo $(0,9 \pm 0,4 \mathrm{mV}$, de uma média de $-65,6 \pm 1,5 \mathrm{mV}$ para $-64,6 \pm 1,4 \mathrm{mV} ; \mathrm{p}=0,06$; Figura 26Bii). 


\section{3 semanas de idade}

$\mathbf{A}$

ii

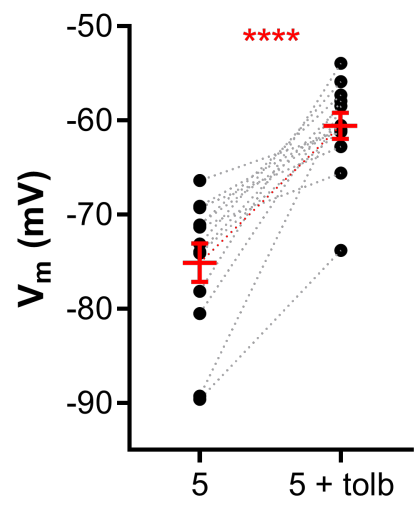

[glicose] (mM)

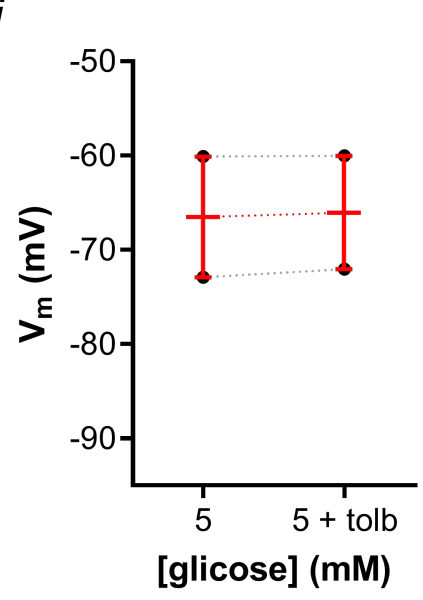

11 semanas de idade

$\mathrm{B} i$

ii
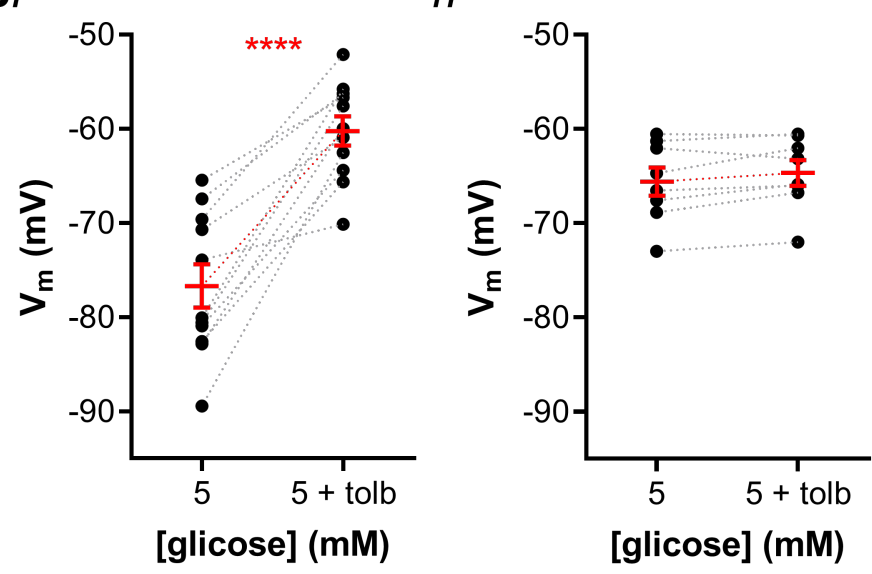

Figura 26. Influência da idade no efeito da tolbutamida em neurônios do NTS. A, resumo do efeito induzido pela tolbutamida no potencial de membrana $\left(V_{m}\right)$ em neurônios responsivos $(\mathbf{A} i)$ e não-responsivos (Aii) de animais com 3 semanas de idade. $\mathbf{B}$, resumo do efeito induzido pela tolbutamida no $V_{m}$ em neurônios responsivos $(\mathbf{B} i)$ e não-responsivos $(\mathrm{B} i i)$ de animais com 11 semanas de idade. Tolb, tolbutamida. ${ }^{* * * *} p<0,0001$.

Similarmente ao efeito observado da baixa glicose em neurônios, verificamos maior proporção de neurônios não-responsivos à tolbutamida em animais com 11 semanas em comparação aos animais com 3 semanas de idade (42\% vs. 13\%, respectivamente; $p<0,0001$; Figura 27C]. Adicionalmente, o RMP de neurônios não-responsivos à tolbutamida em ratos com 11 semanas de idade estava mais despolarizado em comparação aos neurônios responsivos em ambos os grupos de idade ( $p=0,035$; Figura 27B), apesar da despolarização induzida pela aplicação de 
tolbutamida não ser diferente entre os neurônios de animais com 3 e 6 semanas da idade $(14,6 \pm 2,1 \mathrm{mV}$ vs. $16,5 \pm 2,2 \mathrm{mV}$, respectivamente; $p=0,5$; Figura 27A).

A

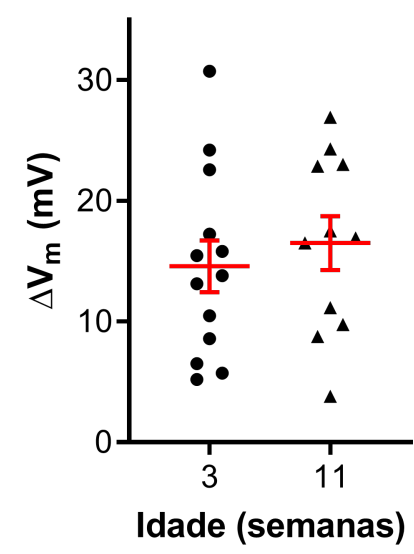

C

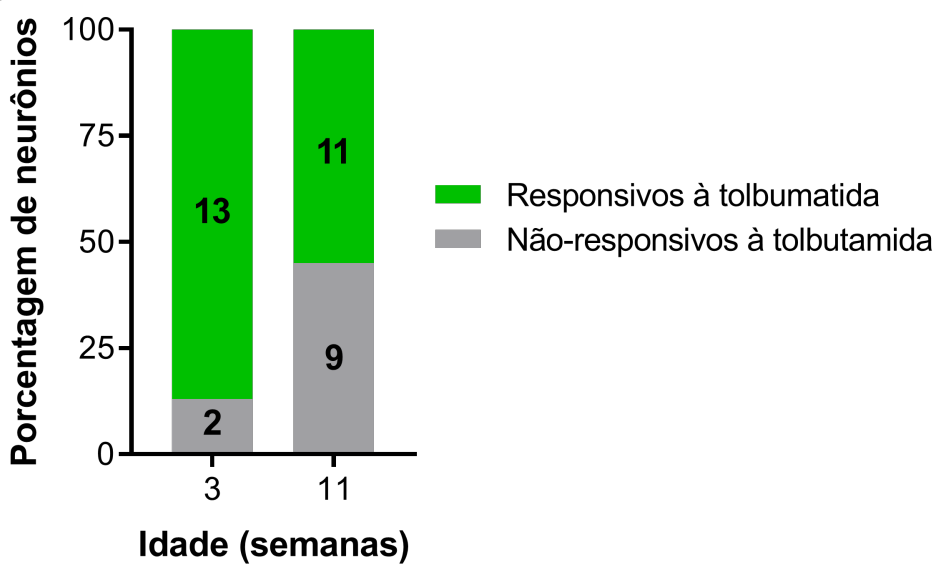

B

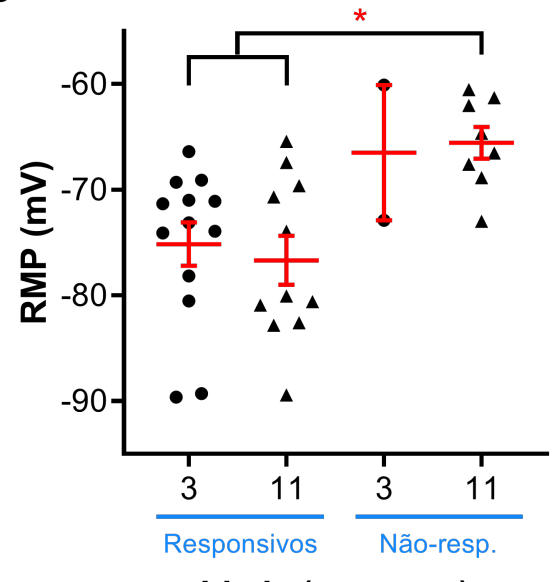

Idade (semanas)

Figura 27. Influência da idade no potencial de repouso da membrana e resposta à tolbutamida. A, comparação da alteração do potencial de membrana $\left(V_{m}\right)$ induzido pela tolbutamida entre neurônios de animais com 3 e 11 semanas de idade. B, comparação do potencial de repouso da membrana (RMP) entre neurônios responsivos e não-responsivos à tolbutamida de com 3 e 11 semanas de idade. $\mathbf{C}$, comparação da distribuição dos neurônios de acordo com a resposta induzida pela tolbutamida em animais com 3 e 11 semanas de idade. ${ }^{*} p<0,05$.

Concluímos que neurônios do NTS de ratos com 11 semanas estão mais despolarizados em comparação a ratos de 3 e 6 semanas de idade, e, portanto, ratos de 11 semanas de idade apresentam menor proporção de neurônios do NTS não-responsivo à baixa glicose e tolbutamida. 
4.2.5. Análise da condutância iônica sensível à baixa glicose extracelular em neurônios do NTS

Recentemente, Lamy et al. (2014) mostraram que uma solução contendo baixa glicose inibe uma condutância vazante para potássio em neurônios GABAérgicos do NTS de camundongos, a qual produz um efeito despolarizante. Entretanto, nossos dados sugerem um efeito distinto do observado por estes autores, pois observamos queda da resistência de entrada da membrana em resposta à baixa glicose em neurônios no presente estudo. Por outro lado, Balfour \& Trapp (2007) reportaram que neurônios do NTS de ratos apresentam respostas despolarizantes distintas quando expostos à baixa glicose: metade dos neurônios exibem a ativação de uma corrente de entrada, enquanto a outra metade dos neurônios apresenta a inibição de uma condutância para potássio ou de uma corrente paralela, esta última sugestiva da inibição da corrente gerada pela bomba $\mathrm{Na}^{+} / \mathrm{K}^{+}$-ATPase.

Nós então investigamos qual a condutância iônica que é responsável pela despolarização induzida por baixa glicose extracelular no presente estudo. Para isso, realizamos relações corrente-voltagem em neurônios do NTS no modo voltageclamp ( $\mathrm{n}=8$, cinco animais), e observamos um efeito similar ao observado por Balfour \& Trapp (2007), onde a perfusão de solução contendo baixa glicose induz aumento da condutância de membrana (medida pela inclinação da curva), de 3,1 \pm $0,1 \mathrm{nS}$ para $4,8 \pm 0,1 \mathrm{nS}(\mathrm{p}<0,0001)$. A baixa glicose produziu uma pequena corrente de entrada $(-57,6 \pm 26,2 \mathrm{pA}$ a $-85 \mathrm{mV})$ com um potencial de reversão aproximado em -60 mV (Figuras 28A e 28B). Interessantemente, o potencial de reversão é próximo do potencial de membrana em que o efeito da baixa glicose não é mais observado. 
A

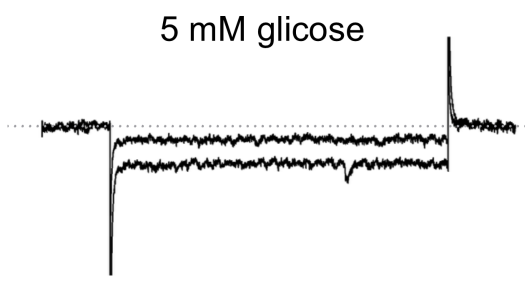

0,5 mM glicose

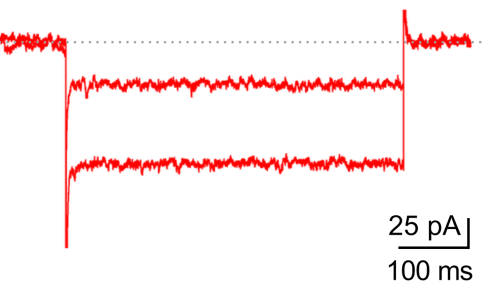

Corrente induzida pela baixa glicose
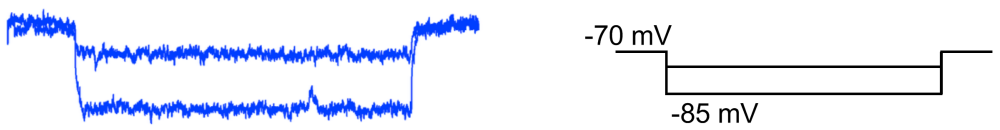

B

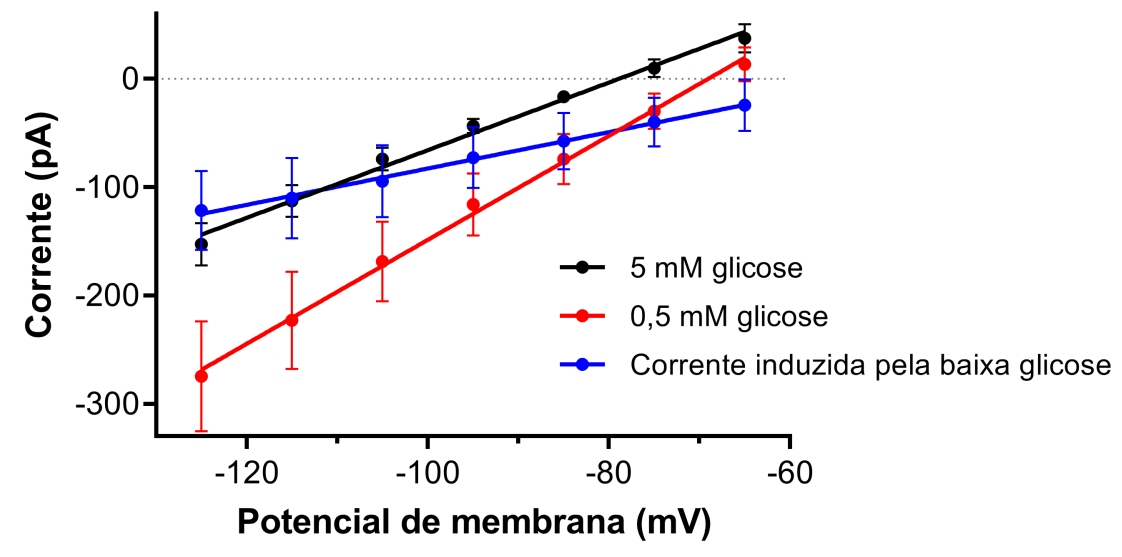

Figura 28. A despolarização induzida pela baixa glicose extracelular é gerada por uma condutância de entrada em neurônios do NTS. A, registros representativos das correntes geradas em resposta a passos de voltagem, obtidas em condição basal ( $5 \mathrm{mM}$ de glicose; preto) e em baixa glicose $(0,5 \mathrm{mM}$; vermelho), e a respectiva subtração das correntes (azul). B, regressão linear da relação corrente-voltagem de neurônios registrados nas condições descritas em A.

Portanto, concluímos que os neurônios do NTS de ratos respondem à baixa glicose por um mecanismo despolarizante que é desenvolvido por uma corrente de entrada que possui potencial de reversão mais positivo ao RMP. Esta observação está de acordo com a diminuição da $R_{\text {input }}$ induzida pela baixa glicose extracelular (Figura 20C) e da despolarização dependente de voltagem (Figura 22A) demonstradas em nossos experimentos.

4.2.6. Modulação dos canais $K_{A T P}$ na sensibilidade à baixa glicose extracelular em neurônios do NTS

Nós mostramos que os neurônios do NTS possuem canais $\mathrm{K}_{\text {ATP }}$ parcialmente abertos em repouso, os quais fortemente afetam o RMP quando inibidos, como 
demonstrado pela despolarização induzida pelo antagonista tolbutamida. Adicionalmente, demonstramos que a perfusão com baixa glicose despolariza 0 RMP de neurônios por um mecanismo dependente de voltagem, onde neurônios não-responsivos possuem RMP mais despolarizados quando comparados aos neurônios responsivos. Portanto, dois sinais opostos (baixa glicose e bloqueio dos canais $\mathrm{K}_{\mathrm{ATP}}$ ) produzem um efeito similar: a despolarização da membrana. Devido à despolarização induzida pela perfusão de baixa glicose ser mais proeminente em neurônios mais hiperpolarizados, nos perguntamos se o neurônio poderia detectar a diminuição na glicose extracelular em uma situação na qual os canais $\mathrm{K}_{\mathrm{ATP}}$ estivessem fechados.

Para testar esta hipótese, nós primeiramente verificamos a resposta do neurônio à baixa glicose extracelular, retornamos para a solução basal inicial, e então aplicamos tolbutamida. Surpreendentemente, todos os neurônios que responderam à baixa glicose também era responsivos à tolbutamida (Figura 29A e 29B). Nestes neurônios, a baixa glicose despolarizou o RMP em 9,1 $\pm 2,2 \mathrm{mV}$ ( $p=$ 0,01; $n=5)$, e após o retorno para a solução inicial, a aplicação de tolbutamida despolarizou o RMP em 18,5 $\pm 3,0 \mathrm{mV}$ ( $p=0,004)$, o que mostra que neurônios responsivos à baixa glicose possuem canais $\mathrm{K}_{\mathrm{ATP}}$ abertos no repouso. Na sequência, a perfusão de baixa glicose na presença de tolbutamida induziu uma pequena, porém significante, despolarização da membrana $(2,0 \pm 0,3 \mathrm{mV} ; \mathrm{p}=0,002)$, a qual foi de magnitude inferior à resposta despolarizante induzida pela baixa glicose antes da aplicação da tolbutamida ( $p=0,03$; Figura 29C). Estes resultados sugerem que a despolarização induzida pelo bloqueio dos canais $\mathrm{K}_{\mathrm{ATP}}$ atenua a resposta neuronal à baixa glicose extracelular. 

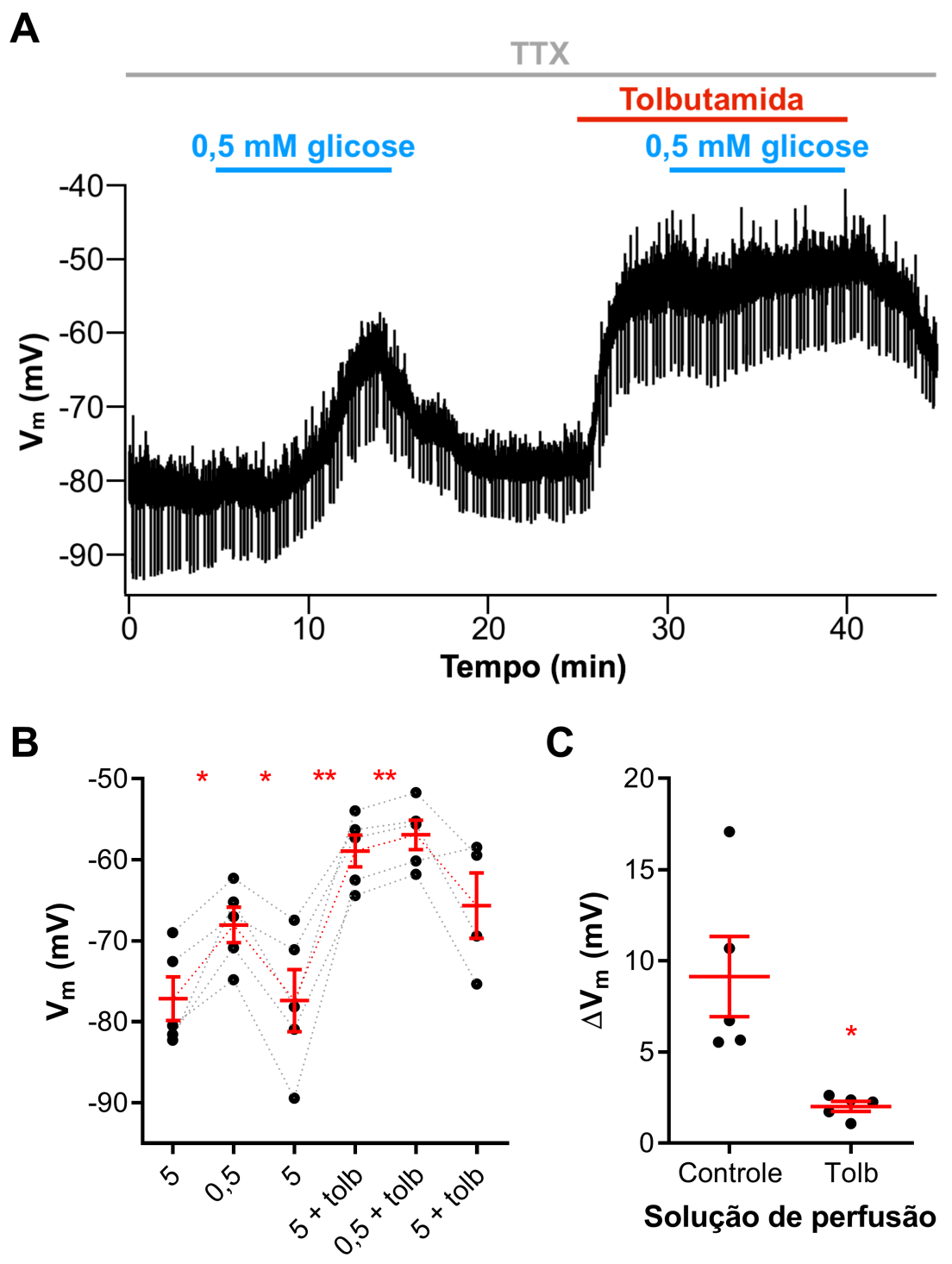

C

[glicose] (mM)

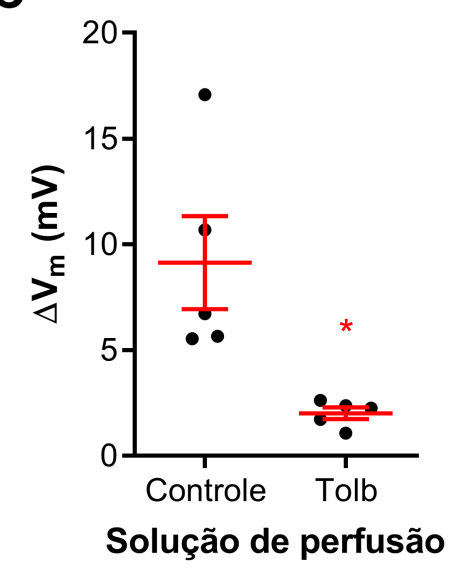

Figura 29. A oclusão dos canais $K_{A T P}$ impede a despolarização induzida pela baixa glicose extracelular em neurônios do NTS. A, registro representativo de um neurônio responsivo à baixa glicose mostra que a aplicação de tolbutamida inibe este efeito despolarizante. B, neurônios responsivos à baixa glicose também são despolarizados pela tolbutamida, mas este efeito oclui a sensibilidade à baixa glicose. C, comparação da amplitude de despolarização induzida pela baixa glicose antes e depois da aplicação de tolbutamida em neurônios mostrada em B. Tolb, tolbutamida; TTX, tetrodotoxina. ${ }^{*} p<0,05 ;{ }^{* *} p<0,01$.

A fim de testar se este efeito é somente devido à despolarização da membrana induzida por tolbutamida, nós repetimos o mesmo protocolo do desafio de baixa glicose, porém hiperpolarizamos os neurônios por injeção de corrente DC após a aplicação de tolbutamida, e então testamos o efeito da perfusão de baixa glicose $(\mathrm{n}=5$; Figura 30A). Novamente, nós verificamos que o potencial de 
membrana é despolarizado pela baixa glicose $(4,4 \pm 0,7 \mathrm{mV} ; \mathrm{p}=0,003)$ e tolbutamida $(12,2 \pm 2,8 \mathrm{mV} ; p=0,001)$. Na sequência, a injeção de -30 a $-50 \mathrm{pA}$ de corrente hiperpolarizou o potencial de membrana (de uma média de $-60,5 \pm 0,8 \mathrm{mV}$ para -76,9 $\pm 1,3 \mathrm{mV}$ ) e, nestas condições, a baixa glicose extracelular foi capaz de despolarizar os neurônios $(6,0 \pm 2,4 \mathrm{mV} ; \mathrm{p}=0,06)$. Entretanto, esta despolarização foi similar à observada na ausência de tolbutamida ( $p=0,6$; Figura 30B), mostrando que a tolbutamida não é capaz de inibir o efeito da baixa glicose se a membrana está hiperpolarizada a valores similares ao RMP basal destes neurônios.

A

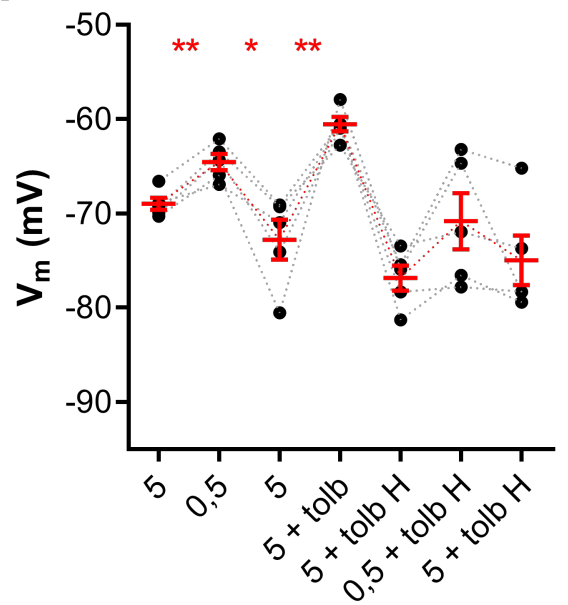

[glucose] (mM)
B

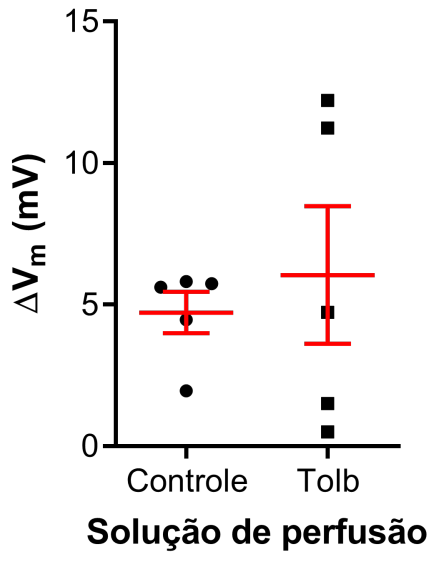

Figura 30. A hiperpolarização do potencial de membrana permite que a baixa glicose extracelular despolarize neurônios do NTS. A, resumo dos efeitos da baixa glicose e tolbutamida no potencial de membrana $\left(V_{m}\right)$ em neurônios responsivos. B, comparação da amplitude de resposta à baixa glicose antes e depois da aplicação de tolbutamida em neurônios mostrada em $\mathbf{A}$. $\mathbf{H}$, potencial de membrana hiperpolarizado; Tolb, tolbutamida; TTX, tetrodotoxina. ${ }^{*} p<0,05$; ${ }^{* *} p<$ 0,01 .

Interessantemente, todos os neurônios não-responsivos à baixa glicose extracelular $(0,6 \pm 0,5 \mathrm{mV} ; \mathrm{p}=0,3 ; \mathrm{n}=5)$ também não foram responsivos à tolbutamida $(1,0 \pm 0,5 \mathrm{mV} ; p=0,1$; Figura 31A). Estes neurônios também estavam com RMP mais despolarizados em comparação aos neurônios responsivos à baixa glicose $(-65,7 \pm 1,9 \mathrm{mV}$ vs. $-73,1 \pm 1,9 \mathrm{mV}$, respectivamente; $p=0,03$; Figura 31B) 
A

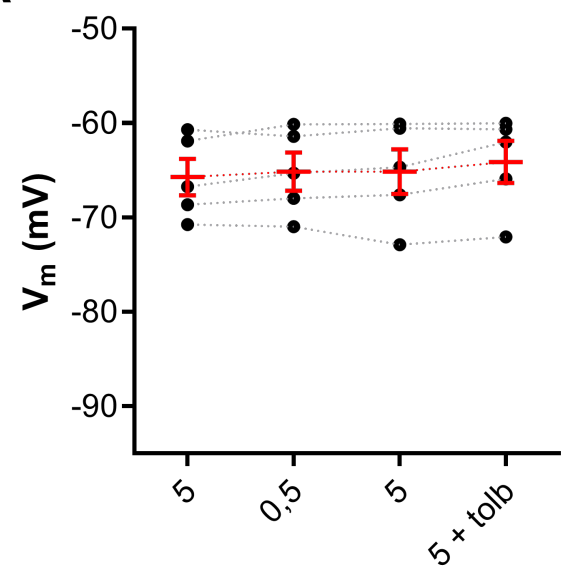

B

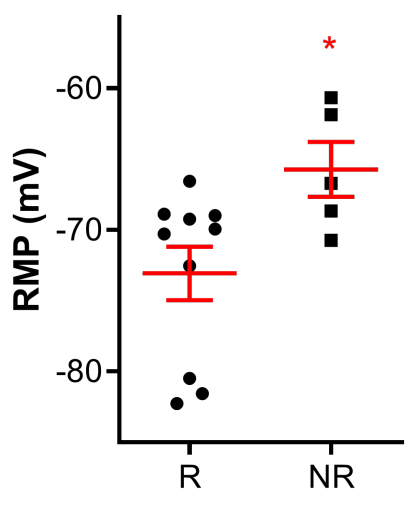

Subtipo neuronal

[glicose] (mM)

Figura 31. Neurônios do NTS não-responsivos à baixa glicose extracelular também não respondem à aplicação de tolbutamida. A, resumo do efeito da aplicação de tolbutamida no potencial de membrana $\left(V_{m}\right)$ em neurônios nãoresponsivos à baixa glicose. $\mathrm{B}$, comparação do potencial de repouso da membrana (RMP) entre neurônios responsivos $(R)$ e não-responsivos (NR) à baixa glicose e tolbutamida. Tolb, tolbutamida. ${ }^{*} p<0,05$.

4.2.7. Sensibilidade à baixa glicose extracelular em neurônios do NTS incubados em condição hiperglicêmica

Pelo fato dos canais $\mathrm{K}_{\text {ATP }}$ estarem parcialmente abertos na maioria dos neurônios do NTS, os quais foram despolarizados quando os bloqueamos, nós nos perguntamos a incubação de neurônios em uma solução hiperglicêmica poderia levar à maior produção de ATP intracelular por meio do metabolismo glicolítico/oxidativo, e consequente bloqueio dos canais $\mathrm{K}_{\mathrm{ATP}}$ e despolarização da membrana. Para isso, incubamos as fatias do tronco encefálico em uma solução contendo $10 \mathrm{mM}$ de glicose ( $\mathrm{n}=17$, oito animais). Assim como esperávamos, verificamos que neurônios incubados em condição hiperglicêmica estavam com RMP mais despolarizados em comparação aos neurônios incubados em $5 \mathrm{mM}$ de glicose $(-69,0 \pm 1,5 \mathrm{mV}$ vs. $-74,5 \pm 1,7 \mathrm{mV}$, respectivamente; Figura 32A. 
A

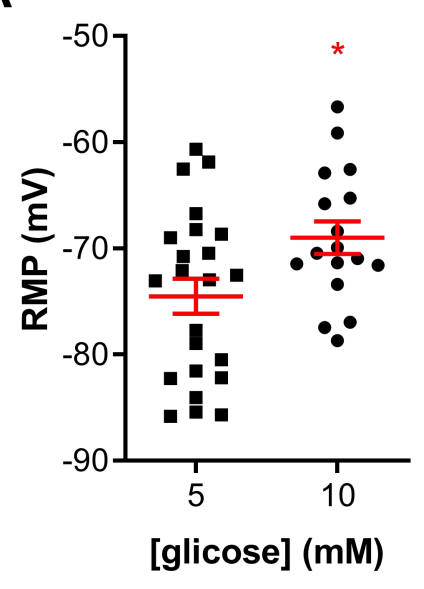

C

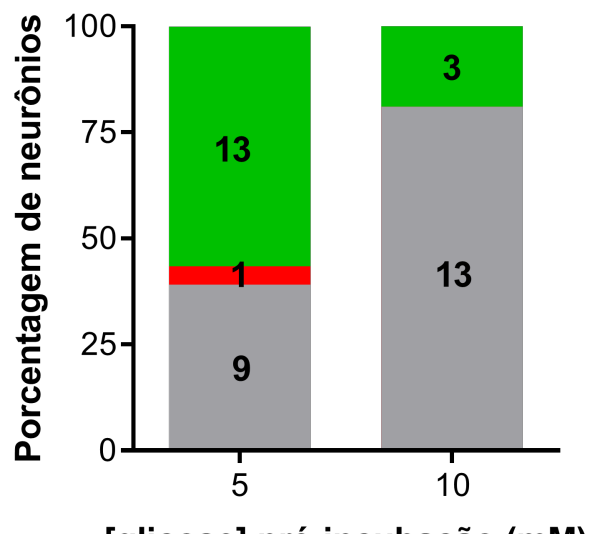

B

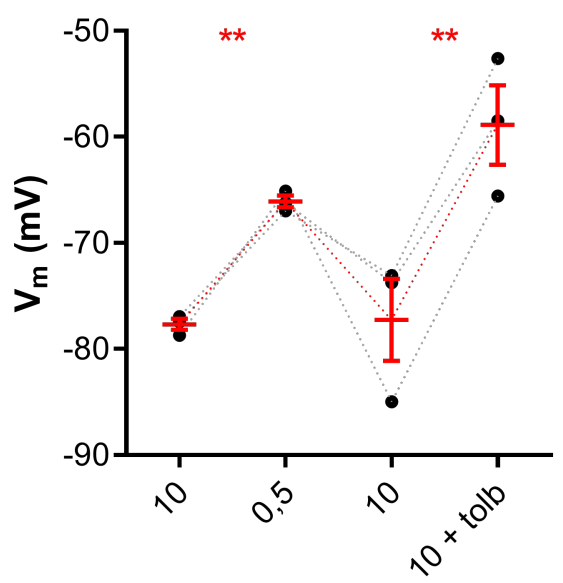

[glicose] (mM)

[glicose] pré-incubação (mM)

Figura 32. A incubação em solução hiperglicêmica diminui o número de neurônios do NTS sensíveis à baixa glicose extracelular. A, comparação do potencial de repouso da membrana (RMP) entre neurônios incubados em solução normo- (5 mM de glicose) e hiperglicêmica (10 mM de glicose). B, resumo do efeito da baixa glicose e tolbutamida no potencial de membrana $\left(V_{m}\right)$ em neurônios responsivos em condição hiperglicêmica. C, comparação da distribuição dos neurônios incubados em solução de 5 e $10 \mathrm{mM}$ de glicose, de acordo com a resposta induzida pela baixa glicose. Tolb, tolbutamida. ${ }^{*} p<0,05 ;{ }^{* *} p<0,01$.

Como anteriormente demonstramos que a resposta à baixa glicose é atenuada em neurônios que estão com RMP mais positivos, nós testamos se neurônios incubados em $10 \mathrm{mM}$ de glicose seriam menos responsivos à solução de baixa glicose em comparação aos neurônios incubados em $5 \mathrm{mM}$ de glicose. Para testar esta hipótese, nós aplicamos a solução de baixa glicose e, após o retorno para a solução inicial contendo $10 \mathrm{mM}$ de glicose, a tolbutamida foi perfundida.

Verificamos que apenas 3 de 16 neurônios (19\%) foram reversivelmente despolarizados pela perfusão da baixa glicose $(11,2 \pm 0,8 \mathrm{mV}$, de uma média de - 
$74,0 \pm 3,7 \mathrm{mV}$ para $-62,8 \pm 3,3 \mathrm{mV} ; \mathrm{p}=0$,0008; Figura 32B). Esta magnitude de despolarização foi similar à encontrada em neurônios incubados em $5 \mathrm{mM}$ de glicose $(p=0,2)$. Interessantemente, a latência para o pico da reposta despolarizante induzida por baixa glicose foi maior em neurônios incubados em $10 \mathrm{mM}$ de glicose em comparação aos neurônios incubados em 5 mM de glicose (435 \pm 30 s vs. $349 \pm$ $19 \mathrm{~s}$, respectivamente; $\mathrm{p}=0,048)$. Após o retorno para a solução inicial contendo 10 $\mathrm{mM}$ de glicose, o RMP também retornou a um valor similar ao RMP basal $(-72,7 \pm$ $5,3 \mathrm{mV} ; \mathrm{p}=0,9)$. Adicionalmente, aplicamos tolbutamida nestes neurônios, a qual produziu uma forte despolarização de 18,4 $\pm 1,6(p=0,007)$, um valor similar ao produzido pela tolbutamida em neurônios incubados em $5 \mathrm{mM}$ de glicose $(p=0,5)$.

Por outro lado, 13 neurônios (81\%) foram considerados não-responsivos à baixa glicose extracelular $(1,4 \pm 0,5 \mathrm{mV}$, de uma média de $-67,5 \pm 1,4 \mathrm{mV}$ para $-66,2$ $\pm 1,4 \mathrm{mV}$; Figura 33B), e estavam com RMP mais despolarizado em comparação aos neurônios responsivos $(-66,0 \pm 2,2 \mathrm{mV}$ vs. $-77,7 \pm 0.5 \mathrm{mM}$, respectivamente; $\mathrm{p}=$ 0,01; Figura 33A). Além disso, a perfusão de tolbutamida foi aplicada em quatro neurônios não-responsivos e não induziu alteração no potencial de membrana $(0,8 \pm$ $0,3 \mathrm{mV} ; \mathrm{p}=0,08$; Figura 33B).

Assim como observado em neurônios incubados em $5 \mathrm{mM}$ de glicose, nós encontramos uma correlação negativa entre a despolarização induzida por baixa glicose e o RMP de neurônios incubados em 10 mM de glicose $\left(r^{2}=0,44 ; p=0,005\right.$; Figura 33C). Corroborando com os achados descritos ao longo do presente estudo, a proporção de neurônios não-responsivos à baixa glicose foi maior em neurônios incubados em 10 mM de glicose em comparação aos neurônios incubados em 5 mM de glicose ( $81 \%$ vs. 39\%, respectivamente; $p<0,0001$; Figura 32A). 
A

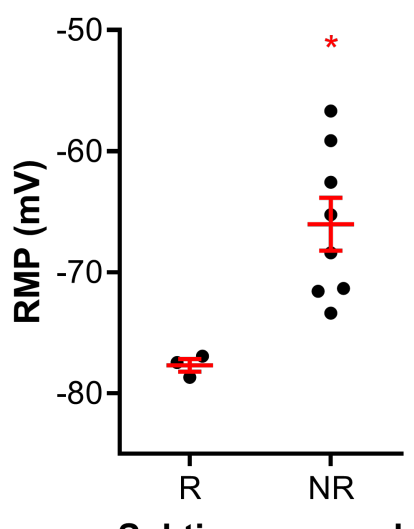

Subtipo neuronal

B

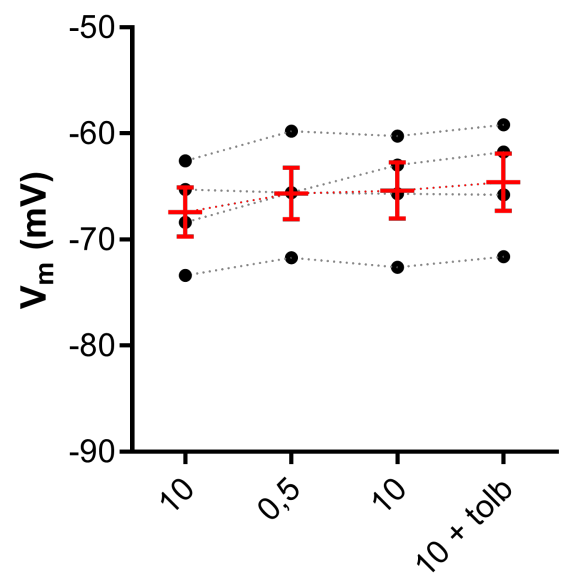

[glicose] (mM)

C

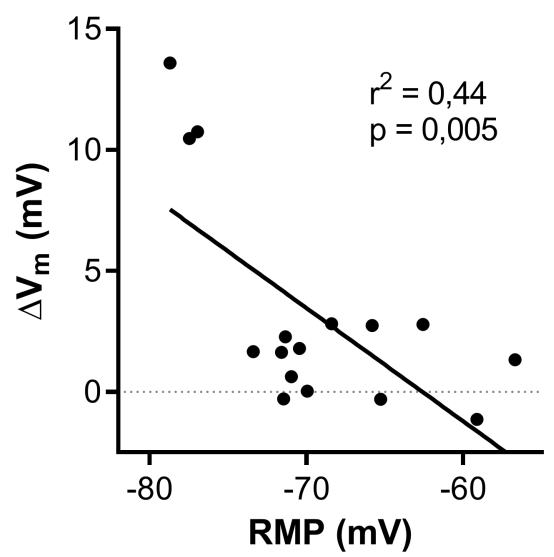

Figura 33. A incubação em solução hiperglicêmica despolariza o potencial de repouso da membrana e resulta em maior número de neurônios do NTS nãoresponsivos à baixa glicose extracelular. $\mathrm{A}$, comparação do potencial de repouso da membrana (RMP) entre neurônios responsivos (R) e não-responsivos (NR) à baixa glicose em condição hiperglicêmica. $B$, resumo dos efeitos da baixa glicose e tolbutamida no potencial de membrana $\left(V_{m}\right)$ em neurônios não-responsivos em condição hiperglicêmica. $C$, correlação linear entre a alteração do $V_{m}$ induzida pela baixa glicose e o RMP em neurônios em condição hiperglicêmica. Tolb, tolbutamida. ${ }^{*} p<0,05$.

A ausência dos efeitos da baixa glicose e tolbutamida no potencial de membrana da maioria dos neurônios do NTS sugere que o aumento da razão ATP/ADP metabólico derivado da incubação em $10 \mathrm{mM}$ de glicose esteja bloqueando os canais $\mathrm{K}_{\text {ATP. }}$. Para testar esta hipótese, nós hiperpolarizamos os neurônios incubados em $10 \mathrm{mM}$ de glicose (de uma média de -71,3 \pm 3,5 mV para $85,1 \pm 2,9 \mathrm{mV} ; \mathrm{n}=5$ ) e então aplicamos a solução contendo baixa glicose, retornamos à solução inicial, e perfusionamos tolbutamida (Figura 34A). 
A

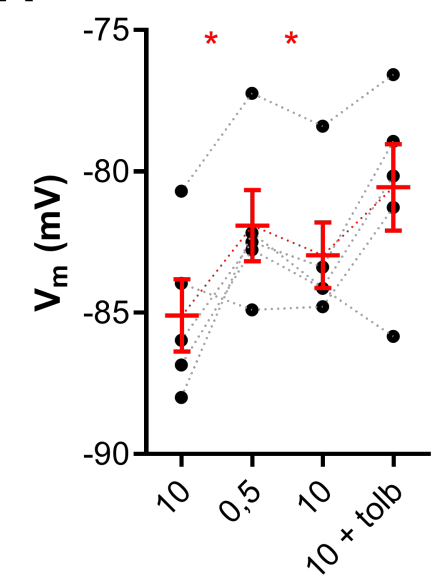

B

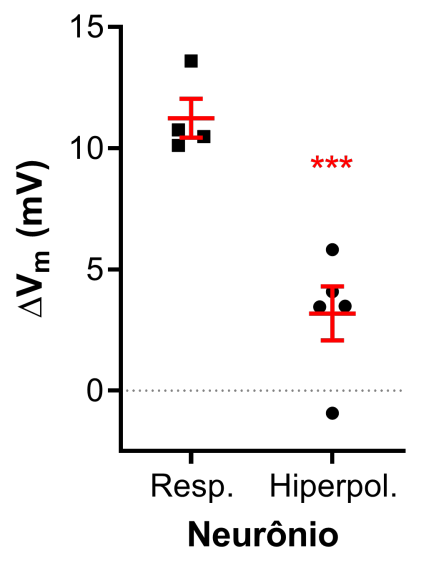

C

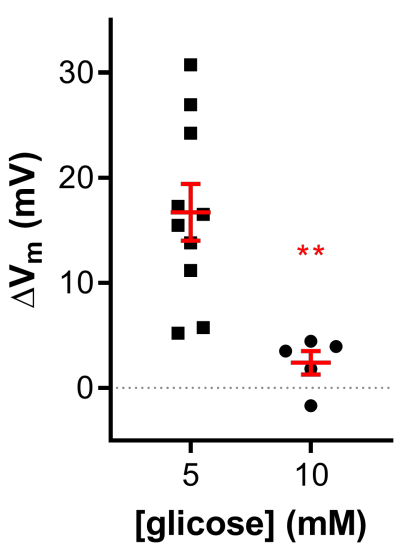

[glicose] (mM)

Figura 34. A hiperpolarização de neurônios do NTS em solução hiperglicêmica não recupera a resposta à baixa glicose extracelular e à aplicação de tolbutamida. A, neurônios incubados em solução hiperglicêmica que estavam em potencial de repouso da membrana (RMP) mais positivo foram hiperpolarizados, e então expostos à baixa glicose e à tolbutamida. B, comparação da alteração do potencial de membrana $\left(V_{m}\right)$ induzida pela baixa glicose entre neurônios responsivos incubados em solução hiperglicêmica e neurônios hiperpolarizados mostrados em $\mathbf{A}$. C, comparação da alteração do $V_{m}$ induzida por tolbutamida entre neurônios incubados em solução normoglicêmica e neurônios mostrados em A. Hiperpol; neurônios hiperpolarizados em condição hiperglicêmica; Resp, neurônios responsivos em condição normoglicêmica; Tolb, tolbutamida. ${ }^{*} p<0,05 ;{ }^{* *} p<0,01$; ${ }^{* * *} p<0,001$.

Surpreendentemente, a resposta à baixa glicose nestes neurônios hiperpolarizados estava presente mas reduzida quando comparada aos neurônios regularmente responsivos $(3,2 \pm 1,1 \mathrm{mV}$ vs. $11,2 \pm 0,8 \mathrm{mV}$, respectivamente; $\mathrm{p}=$ 0,0004; Figura 34B), o que sugere que a resposta à baixa glicose é atenuada em neurônios incubados em 10 mM de glicose. Por outro lado, os neurônios que foram hiperpolarizados continuam não-responsivos à tolbutamida $(2,4 \pm 1,1 \mathrm{mV}$, de uma média de $-83,0 \pm 1,2 \mathrm{mV}$ para -80,6 $\pm 1,5 \mathrm{mV} ; \mathrm{p}=0,1$; Figura 34A). Embora alguns neurônios apresentem uma pequena resposta à baixa glicose, a magnitude de despolarização foi muito menor em relação ao observado em neurônios incubados em $5 \mathrm{mM}$ de glicose ( $p=0,03$; Figura $\mathbf{3 4 C}$ ). Em conjunto, estes resultados estão de acordo com a hipótese de que o aumento da razão ATP/ADP intracelular causado pela incubação dos neurônios em $10 \mathrm{mM}$ de glicose esteja bloqueando os canais $\mathrm{K}_{\mathrm{ATP}}$. 
Portanto, concluímos que a incubação de neurônios do NTS em uma condição hiperglicêmica diminui o número de neurônios responsivos à baixa glicose extracelular. Embora este efeito não seja causado pelo potencial de membrana mais despolarizado, estes neurônios apresentam atenuação da resposta à baixa glicose quando hiperpolarizados. Por outro lado, o RMP mais despolarizados em neurônios incubados em uma solução hiperglicêmica sugere que o aumento da glicose extracelular pode aumentar a razão ATP/ADP intracelular, o que consequentemente leva ao bloqueio dos canais $\mathrm{K}_{\mathrm{ATP}}$ e despolarização da membrana neuronal.

4.2.8. Efeito da exposição prolongada à baixa glicose extracelular em neurônios do NTS

Devido à modulação dos canais $\mathrm{K}_{\mathrm{ATP}}$ no RMP de neurônios do NTS, e às evidências de que a razão ATP/ADP intracelular pode controlar o RMP por meio dos canais $\mathrm{K}_{\mathrm{ATP}}$, nós testamos se a despolarização induzida pela perfusão de baixa glicose seria mantida quando mantida por um período prolongado, já que o ATP metabólico seria reduzido. Para isso, monitoramos o efeito da baixa glicose durante 20-30 minutos $(n=4)$.

Verificamos que em três neurônios a despolarização causada pela solução de baixa glicose começou a reverter após $1033 \pm 101 \mathrm{~s}$. Em dois destes neurônios aplicamos tolbutamida, a qual despolarizou o potencial de membrana a valores similares ao inicialmente induzido pela baixa glicose (Figura 35A e 35B), o que sugere que a hiperpolarização foi causada pela abertura de canais $\mathrm{K}_{\mathrm{ATP}}$. 
A

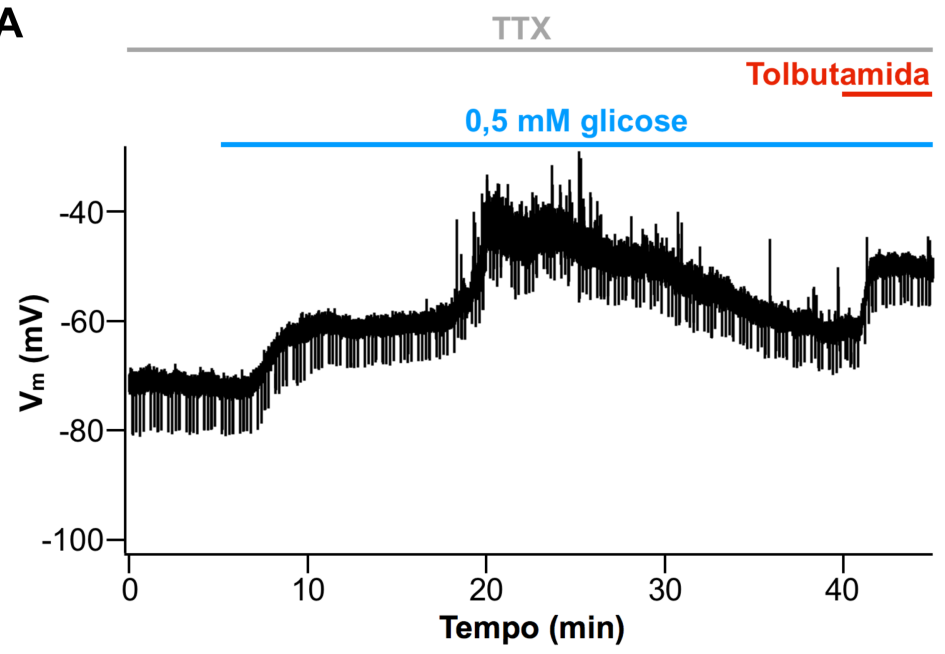

B

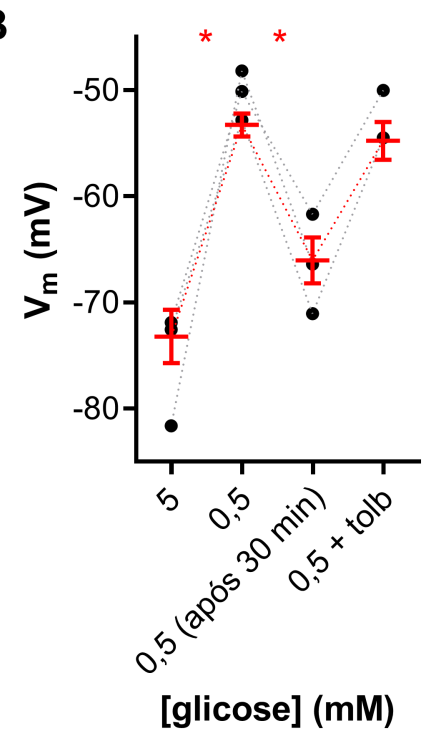

Figura 35. A despolarização do potencial de membrana gerada por uma longa exposição à baixa glicose extracelular é revertida pela abertura dos canais $\mathrm{K}_{\text {ATP }}$ em neurônios do NTS. Grupo de neurônios despolarizados pela baixa glicose apresenta hiperpolarização após um longo período de exposição (B), como demonstrado no registro representativo em $\mathbf{A}$. Note que a tolbutamida reverte o efeito hiperpolarizante induzido pela baixa glicose. Tolb, tolbutamida; TTX, tetrodotoxina; $V_{m}$, potencial de membrana. ${ }^{*} p<0,05$.

Interessantemente, o único neurônio não-responsivo à solução contendo baixa glicose foi hiperpolarizado após 1300 s de exposição a esta condição, e a aplicação de tolbutamida reverteu o efeito hiperpolarizante (Figura 36), o que também sugere que este efeito foi causado pela abertura de canais $\mathrm{K}_{\text {ATP. }}$.

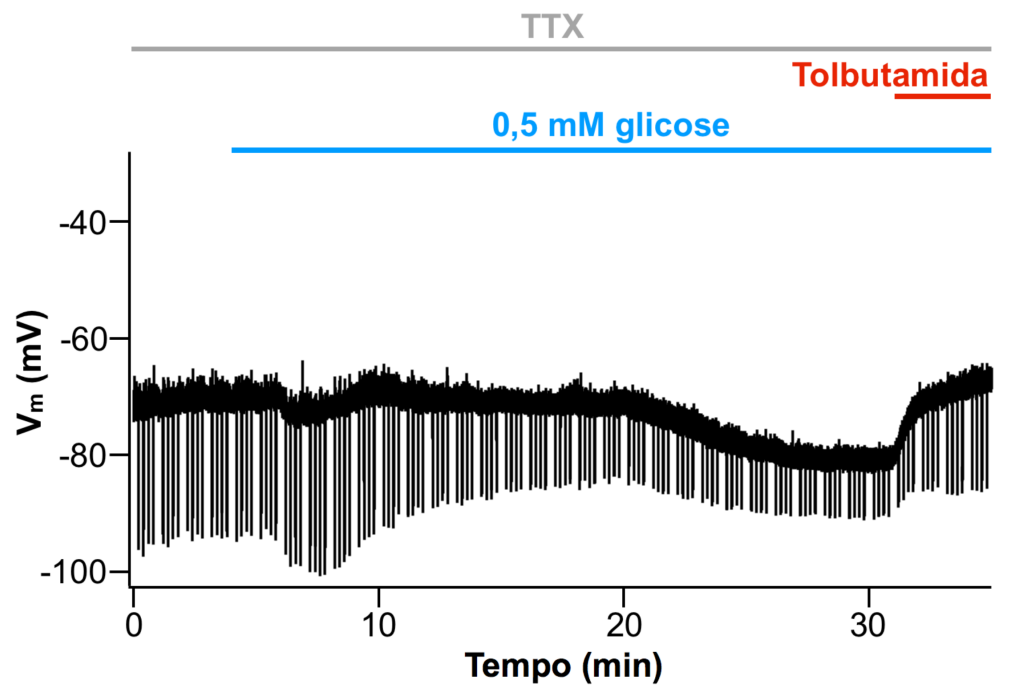

Figura 36. Neurônio não-responsivo à baixa glicose extracelular são hiperpolarizados após um longo período de exposição à baixa glicose. Registro 
representativo de um neurônio não-responsivo à baixa glicose mostra a hiperpolarização causada pela longa exposição à baixa glicose. TTX, tetrodotoxina; $\mathrm{V}_{\mathrm{m}}$, potencial de membrana.

Para investigar ainda mais a modulação dos canais $\mathrm{K}_{\text {ATP }}$ na sensibilidade à baixa glicose extracelular em neurônios do NTS, aplicamos a tolbutamida durante a despolarização induzida pela baixa glicose $(n=3)$. Nestes neurônios, a aplicação de tolbutamida evitou a hiperpolarização causada pela exposição prolongada à baixa glicose (Figura 37A e 37B). Portanto, concluímos que o efeito da baixa glicose em despolarizar os neurônios do NTS é mantida por curto prazo, e provavelmente é causada pela depleção do ATP metabólico e consequente abertura dos canais $\mathrm{K}_{\text {ATP. }}$.

A

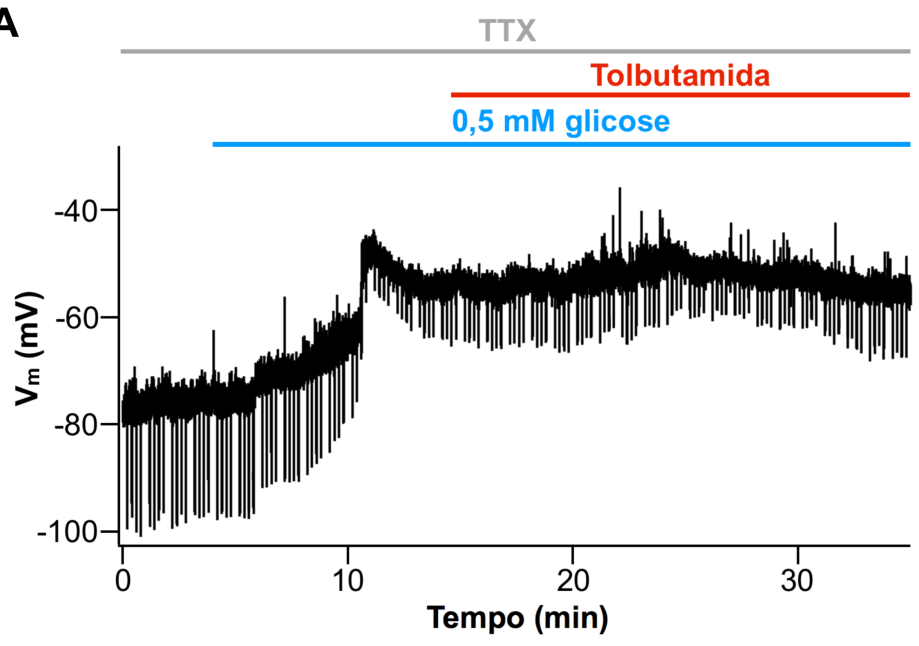

B

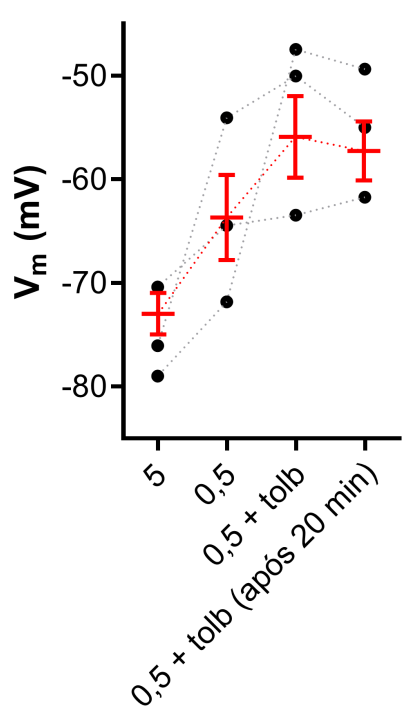

[glicose] (mM)

Figura 37. O fechamento dos canais $\mathrm{K}_{\text {ATP }}$ é suficiente para inibir a hiperpolarização induzida por uma longa exposição à baixa glicose extracelular em neurônios do NTS. A aplicação de tolbutamida inibe o efeito hiperpolarizante induzido por um longo período de exposição à baixa glicose em neurônios (B), como demonstrado no registro eletrofisiológico representativo em $\mathbf{A}$. Tolb, tolbutamida; TTX, tetrodotoxina; $\mathrm{V}_{\mathrm{m}}$, potencial de membrana.

\subsection{Sensibilidade à baixa glicose extracelular em astrócitos do NTS}

No presente estudo, demonstramos que a maioria dos neurônios do NTS são sensíveis a flutuações da concentração de glicose extracelular. Contudo, diversas evidências mostram que os astrócitos também são importantes reguladores do metabolismo da glicose (Marty et al., 2005; Belanger et al., 2011; García-Cáceres et al., 2016; Fernandez et al., 2017), o que nos motivou a avaliar o efeito da baixa 
glicose extracelular em astrócitos do NTS. Além disso, visamos investigar a existência de uma comunicação astrócito-neurônio no NTS, bem como se a baixa glicose extracelular poderia modular esta sinalização. Para isso, todos os ensaios experimentais com imagens de cálcio utilizando o indicador de cálcio Fluo-4-AM em astrócitos do NTS foram realizados simultaneamente aos registros eletrofisiológicos em neurônios adjacentes, como demonstrado na Figura 8.

\subsubsection{Identificação de astrócitos para imagens de cálcio}

Os astrócitos do NTS foram identificados por meio da marcação seletiva por sulforodamina 101 (SR101), a qual foi visualizada pela excitação por um comprimento de onda de $586 \mathrm{~nm}$ sob microscopia epifluorescente (Figura 6). Após a realização das imagens de cálcio, a identidade de alguns astrócitos foi confirmada por propriedades eletrofisiológicas, como pela ausência de disparo de potenciais de ação após a injeção de correntes despolarizantes (Figura 7A), e pela ausência de canais de sódio dependentes de voltagem (Figura 7B). Deste modo, garantimos que as oscilações de cálcio analisadas no presente estudo fossem exclusivamente obtidas de astrócitos.

\subsubsection{Efeito da baixa glicose extracelular na atividade de cálcio em astrócitos} do NTS

Primeiramente, pré-incubamos as fatias do tronco encefálico em solução aCSF contendo $5 \mathrm{mM}$ de glicose e o indicador Fluo-4-AM por 20 minutos. Então, monitoramos a intensidade do sinal fluorescente $\left(\Delta F / F_{0}\right)$ emitida pelas oscilações de cálcio citosólico em astrócitos do NTS, como mostra a Figura 38. 
A
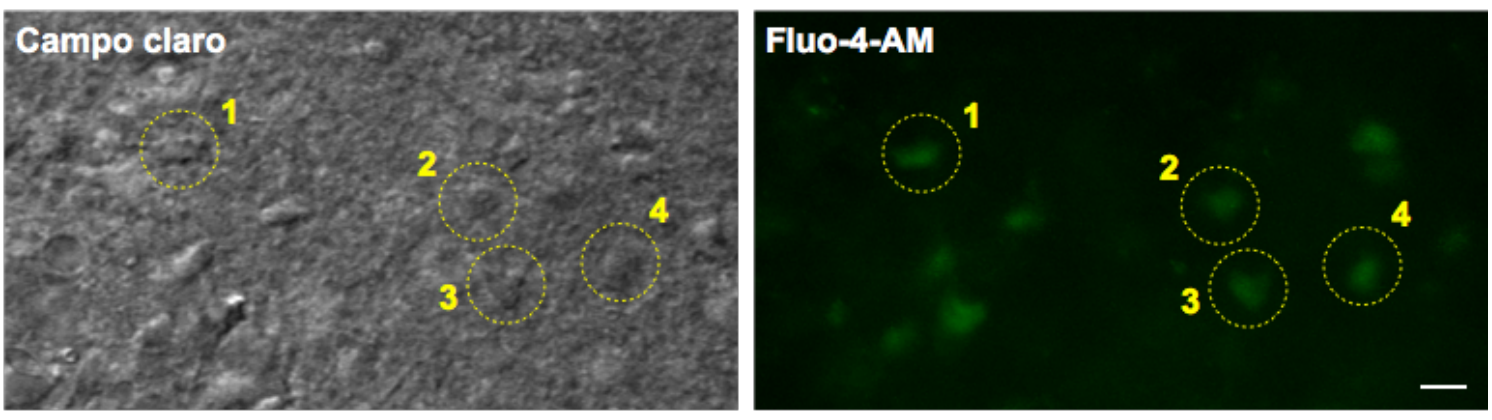

B

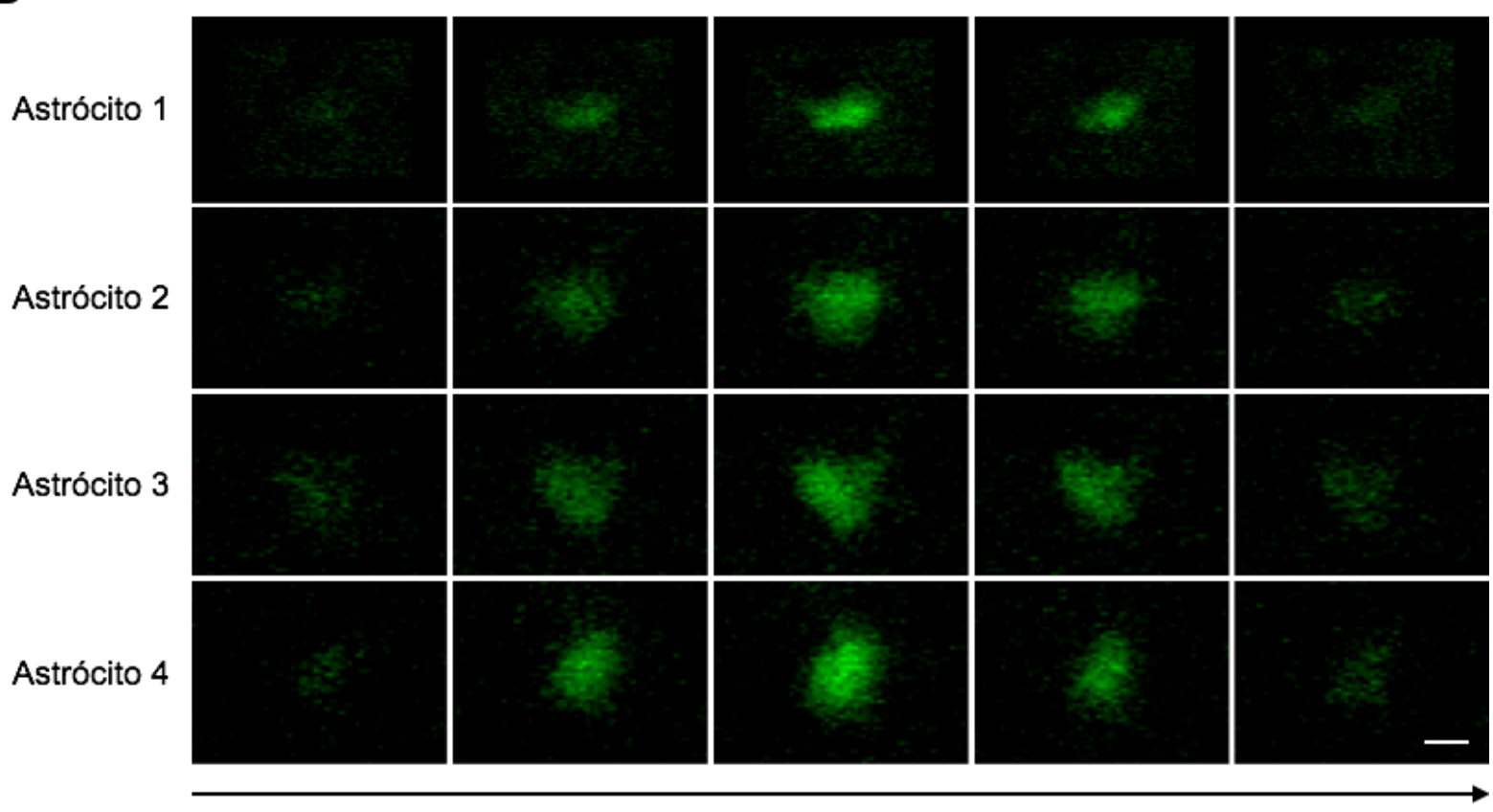

Tempo

Figura 38. Oscilações espontâneas de cálcio em astrócitos do NTS. A, imagens representativas mostram astrócitos do NTS durante um experimento utilizando imagens de cálcio por meio do indicador Fluo-4-AM. À esquerda, micrografia obtida por óptica DIC. À direita, imagem em z-stack obtida pela excitação de Fluo-4-AM sob microscopia epifluorescente. Escala horizontal: $15 \mu \mathrm{m}$. B, as imagens demonstram a intensidade do sinal emitido por Fluo-4-AM durante uma oscilação espontânea de cálcio nos astrócitos indicados em $\mathbf{A}$. Escala horizontal: $8 \mu \mathrm{m}$.

Com o intuito de avaliar a sensibilidade à baixa glicose extracelular em astrócitos do NTS, perfundimos uma solução contendo $0,5 \mathrm{mM}$ de glicose e observamos a atividade de cálcio em astrócitos do NTS ( $\mathrm{n}=162$ astrócitos, 12 fatias, cinco animais; Figura 39B e 39C). Verificamos um aumento da frequência de oscilações de cálcio por minuto $\left(\mathrm{osc}^{\mathrm{min}-1}\right)$ quando os astrócitos foram expostos à baixa glicose $\left(0,27 \pm 0,06\right.$ osc $^{\text {min-1 }}$, de uma média de $0,32 \pm 0,03$ osc $^{\text {min-1 }}$ para $0,59 \pm$ 0,05 osc $^{\text {min-1 }} ; p<0,0001$; Figura 39D). A Figura 39A mostra um exemplo de um pico de cálcio em um astrócito em resposta à baixa glicose extracelular. Entretanto, 
observamos diferentes respostas de astrócitos à baixa glicose extracelular em relação à alteração da frequência de oscilações de cálcio citosólico: $51,2 \%$ dos astrócitos aumentaram a frequência, 21,6\% diminuíram a frequência, e 27,2\% não alteraram a frequência (Figura 39E), o que resultou no aumento da porcentagem de astrócitos ativos em baixa glicose em comparação à condição normoglicêmica $(21,1$ $\pm 8,6 \%$, de uma média de 44,9 $\pm 6,0 \%$ para $66,0 \pm 6,5 \%$; $p=0,03$; Figura 39F). Estes dados mostram que astrócitos do NTS apresentam oscilações espontâneas de cálcio citosólico em condições normoglicêmicas, e que a baixa glicose extracelular pode regular a atividade de cálcio na maioria dos astrócitos.

O principal mecanismo que desencadeia o aumento da concentração de cálcio citosólico no soma de astrócitos é mediado pelo receptor $\mathrm{IP}_{3}$ tipo $2\left(\mathrm{IP}_{3} \mathrm{R} 2\right)$, o qual participa da mobilização de cálcio armazenado nos retículos endoplasmáticos. Para avaliar se a sinalização por $\mathrm{IP}_{3} \mathrm{R} 2$ poderia modular a resposta à baixa glicose extracelular em astrócitos do NTS, analisamos as oscilações de cálcio em astrócitos de fatias de camundongos knock-out para $\mathrm{IP}_{3} \mathrm{R} 2\left(\mathrm{IP}_{3} \mathrm{R} 2^{-/-}\right)$, os quais possuem ampla deficiência na mobilização interna de cálcio mediada por $\mathrm{IP}_{3} \mathrm{R} 2$ em astrócitos $(\mathrm{n}=$ 192 astrócitos, oito fatias, dois animais; Figura 39C).

Observamos que os camundongos $\mathrm{IP}_{3} \mathrm{R} 2^{-/-}$apresentaram menor porcentagem de astrócitos espontaneamente ativos quando comparados aos animais controle, $(13,6 \pm 2,3 \%$ vs. $44,9 \pm 6,0 \%$, respectivamente; $p=0,0007$; Figura 39F), bem como diminuição da atividade de cálcio basal $\left(0,09 \pm 0,02\right.$ osc $^{\text {min-1 }}$ vs. $0,31 \pm 0,04$ osc $^{\text {min-1 }}$ em animais controle; $p=0,0003$; Figura 39D). Interessantemente, a solução contendo baixa glicose não induziu aumento da frequência das oscilações de cálcio nos astrócitos $\left(0,02 \pm 0,01\right.$ osc $^{\text {min-1 }}$, de uma média de 0,09 $\pm 0,02$ osc $^{\text {min-1 }}$ para 0,11 \pm 0,06 osc $^{\text {min-1 }} ; p=0,2$; Figura 39C e 39D) nem o aumento da porcentagem de astrócitos ativos $(1,9 \pm 2,2 \%$, de uma média de 13,6 $\pm 2,3 \%$ para $15,5 \pm 2,5 \%$; $p=$ 0,4 ; Figura 39F). Nossos resultados mostram que a maioria dos astrócitos $(77,6 \%)$ de camundongos $\mathrm{IP}_{3} \mathrm{R} 2$ não respondeu à baixa glicose extracelular, enquanto apenas $10,4 \%$ do astrócitos aumentaram a frequência das oscilações de cálcio, e 12,0\% diminuíram a frequência (Figura 39E).

Portanto, nossos dados mostram que a grande maioria dos astrócitos do NTS dependem da mobilização interna de cálcio mediada por $\mathrm{IP}_{3} \mathrm{R} 2$ para a geração de oscilações espontâneas de cálcio citosólico, bem como para a indução da resposta à baixa glicose extracelular. 
A
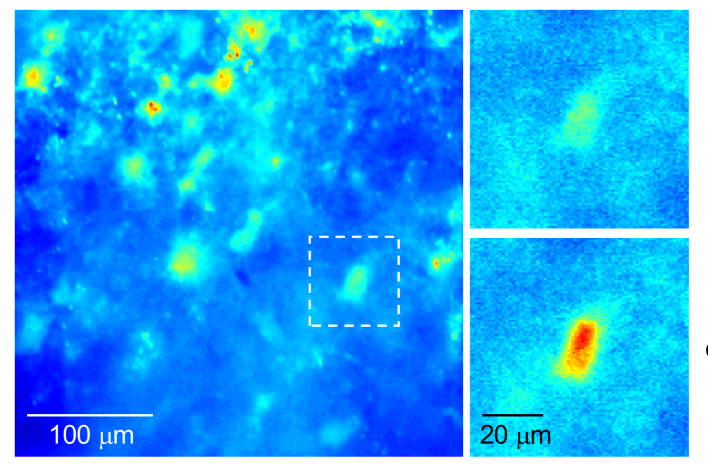

C

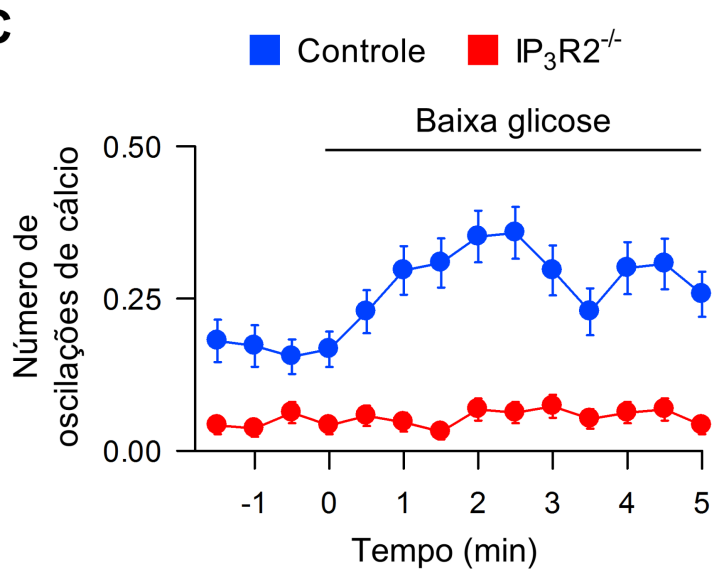

E

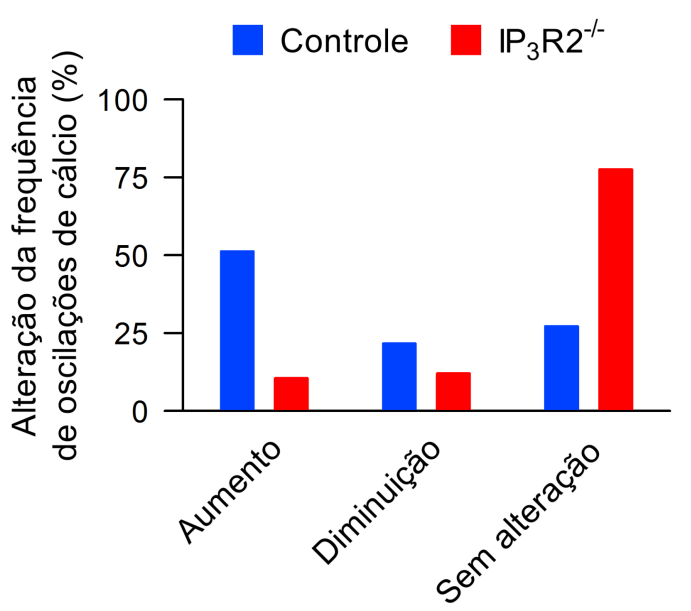

B
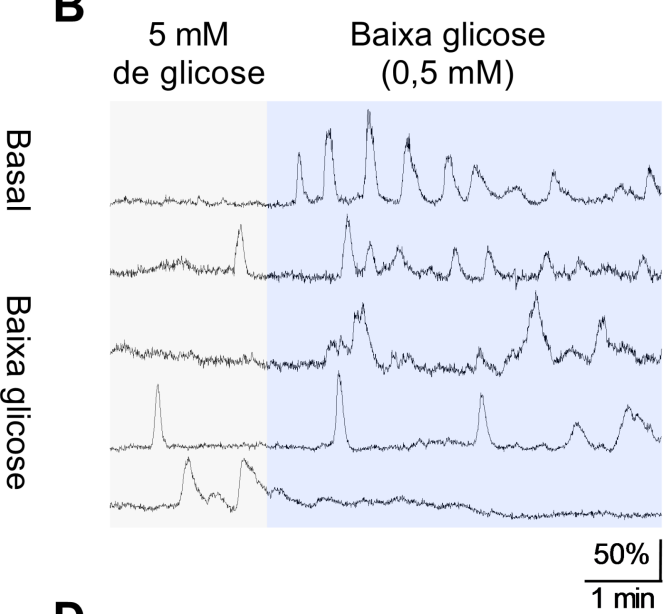

D $\square$ Basal $\square$ Baixa glicose

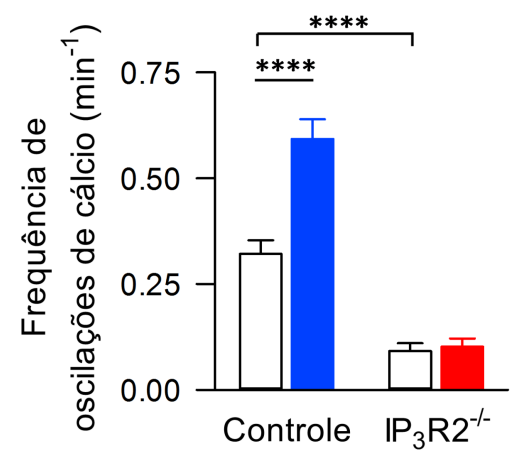

$\mathbf{F}$

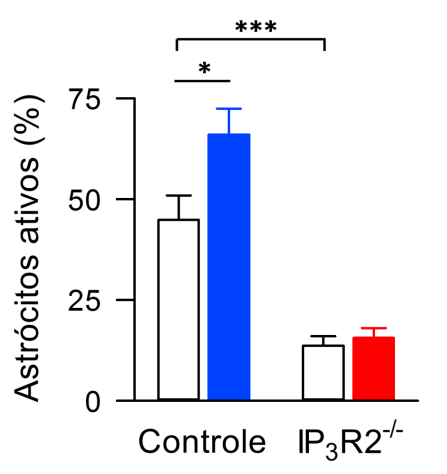

Figura 39. A baixa glicose extracelular ativa astrócitos do NTS por um mecanismo dependente de $\mathbf{I P}_{3} \mathbf{R} \mathbf{2}$. $\mathbf{A}$, imagem representativa em pseudocor demonstra a intensidade do sinal emitido pelo indicador de cálcio Fluo-4-AM obtidas por microscopia epifluorescente em astrócitos. Em destaque à direita, um astrócito silente em condição basal ( $5 \mathrm{mM}$ de glicose; acima) e ativado em baixa glicose $(0,5$ $\mathrm{mM}$; abaixo). B, traçados representativos mostram a intensidade da fluorescência $\left(\Delta \mathrm{F} / \mathrm{F}_{0}\right)$ adquirida no soma de astrócitos durante o desafio da baixa glicose. C, número de oscilações de cálcio citosólico em astrócitos expostos à baixa glicose em animais controle (azul) e $\mathrm{IP}_{3} \mathrm{R}^{-/-}$(vermelho). D, comparação da frequência das 
oscilações de cálcio citosólico em astrócitos em condição normoglicêmica e quando expostos à baixa glicose, em animais controle e $\mathrm{IP}_{3} \mathrm{R} 2^{-/-}$. $\mathbf{E}$, comparação da porcentagem de astrócitos ativos em condição basal e em resposta à baixa glicose, em animais controle e $\mathrm{IP}_{3} \mathrm{R} 2^{-/-}$. $\mathbf{F}$, comparação da distribuição dos astrócitos de acordo com a alteração da frequência de oscilações de cálcio induzida pela baixa glicose, em animais controle e $\mathrm{IP}_{3} \mathrm{R} 2{ }^{-/-}$. ${ }^{*} p<0,05$; ${ }^{* *} p<0,01$; ${ }^{* * * *} p<0,0001$.

\subsubsection{Efeito da baixa glicose extracelular na gliotransmissão no NTS}

Visto que astrócitos do NTS podem responder à baixa glicose extracelular, decidimos investigar a existência de sinalização astrócito-neurônio no NTS induzida pela baixa glicose. Para isso, avaliamos a presença de SICs em neurônios do NTS por whole-cell patch-clamp ( $n=21$, cinco animais) simultaneamente às imagens de cálcio (Figura 8), o que poderia evidenciar a gliotransmissão por glutamato. Observamos que as SICs estão presentes em neurônios do NTS incubados em condição normoglicêmica, e que a baixa glicose extracelular aumenta a frequência de SICs, apesar desta diferença não ser estatisticamente significativa $(0,17 \pm 0,12$ SICs, de uma média de 0,12 \pm 0,06 SICs para 0,29 $\pm 0,12$ SICs, respectivamente; $p$ = 0,2; Figura 40B e 40C). As SICs foram bloqueadas na presença de D-2-amino-5fosfonopentanoico (DLAP5; Figura 40C). No total, 28,6\% dos neurônios apresentaram aumento da frequência de SICs quando expostos à baixa glicose, e 14,3\% diminuição da frequência (Figura 40D). Por outro lado, 57,1\% não alteraram a frequência de SICs em baixa glicose; entretanto, estes neurônios também não apresentaram SICs em condição normoglicêmica, o que sugere que estes neurônios não expressam NMDARs extrassinápticos.

A fim de investigar se a gliotransmissão glutamatérgica induzida pela baixa glicose extracelular é dependente da mobilização de cálcio mediada por $I_{3} R 2$ em astrócitos do NTS, analisamos a presença de SICs em neurônios de camundongos $\mathrm{IP}_{3} \mathrm{R} 2^{-/-}$( $\mathrm{n}=11$, dois animais $)$. Interessantemente, não observamos SICs espontâneas em nenhum neurônio registrado (Figura 40C), e a baixa glicose não alterou a frequência de SICs em neurônios do NTS (Figura 40C e 40D). 
A

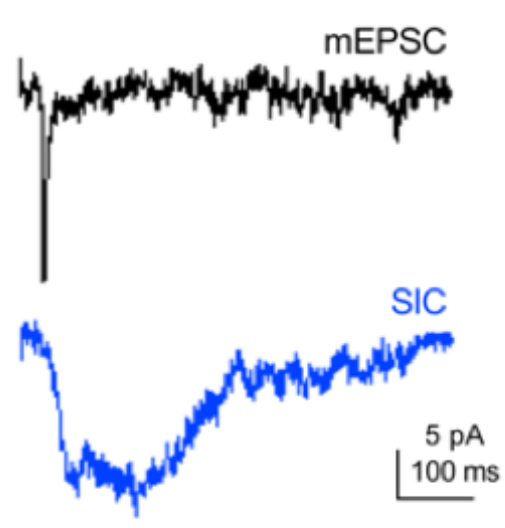

C

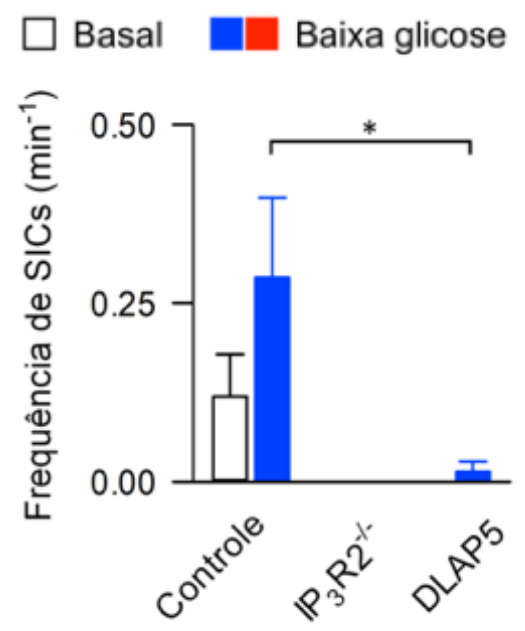

B

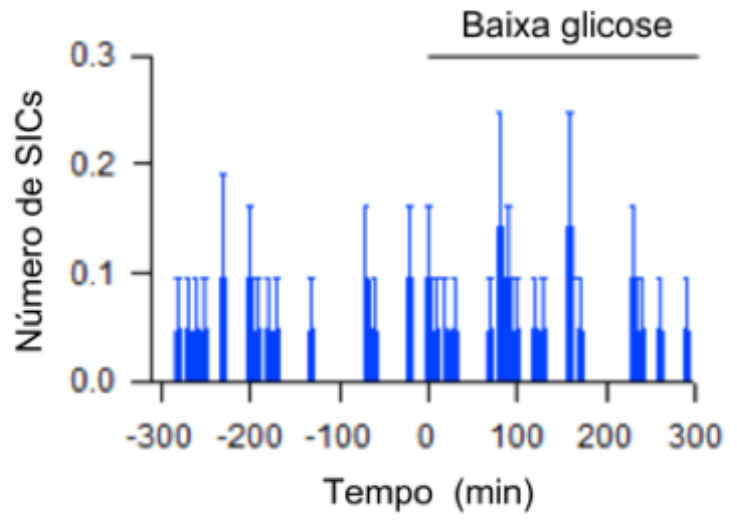

D

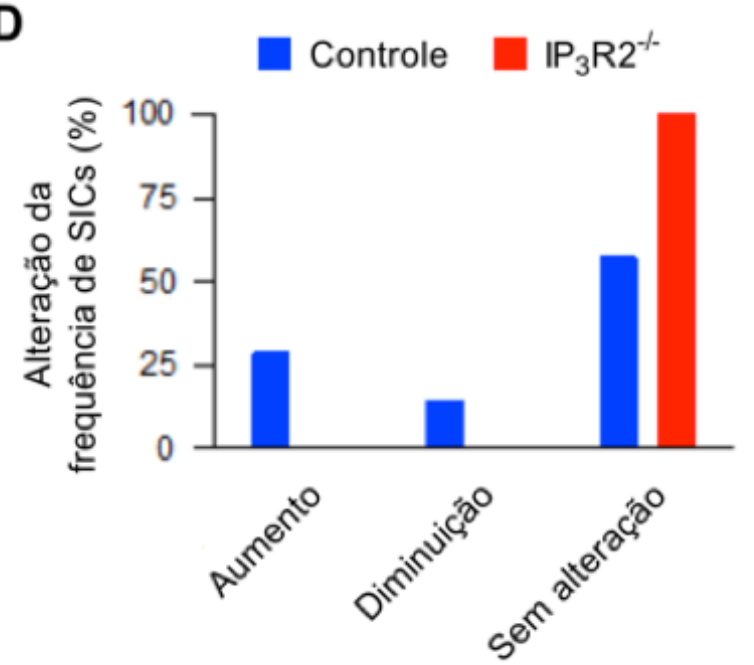

Figura 40. A gliotransmissão glutamatérgica presente no NTS pode ser regulada pela baixa glicose extracelular. $\mathbf{A}$, comparação das cinéticas de ativação e inativação entre uma corrente de entrada lenta (SIC; em azul) e uma minicorrentes excitatórias pós sinápticas (mEPSC; em preto). B, número de SICs registrados em neurônios expostos à baixa glicose. C, comparação da frequência de SICs neuronais em condição normoglicêmica e quando expostos à baixa glicose, em animais controle e $\mathrm{IP}_{3} \mathrm{R}^{-/}{ }^{-}$, e na presença de DLAP5. D, comparação da distribuição dos neurônios de acordo com a alteração da frequência das SICs induzida pela baixa glicose, em animais controle e $\mathrm{IP}_{3} \mathrm{R} 2^{-1-}$.

Estes resultados indicam a presença de comunicação astrócito-neurônio no NTS em condições normoglicêmicas, a qual pode ser modulada pela baixa glicose extracelular em uma pequena proporção de neurônios. Adicionalmente, a mobilização interna de cálcio mediada por $\mathrm{IP}_{3} \mathrm{R} 2$ em astrócitos do NTS é necessária para induzir a gliotransmissão por glutamato em resposta à baixa glicose. 
4.3.4. Sensibilidade à baixa glicose extracelular e gliotransmissão em astrócitos do NTS incubados em condição hiperglicêmica

Como verificamos que a sensibilidade à baixa glicose extracelular em neurônios do NTS é modulada por uma condição inicial hiperglicêmica, nos perguntamos se este fenômeno poderia ocorrer em astrócitos incubados nas mesmas condições. Então, incubamos as fatias em solução contendo $10 \mathrm{mM}$ de glicose, e monitoramos a resposta à baixa glicose extracelular $(0,5 \mathrm{mM}) \mathrm{em}$ astrócitos do NTS ( $\mathrm{n}=208$ astrócitos, 12 fatias, três animais).

A perfusão de baixa glicose extracelular não alterou a proporção de astrócitos ativos $(-4,4 \pm 4,8 \%$, de uma média de $80,0 \pm 2,4 \%$ para $75,6 \pm 4,6 \%$; $p=0,04$; Figura 41D) nem a frequência das oscilações de cálcio em astrócitos incubados em $10 \mathrm{mM}$ de glicose $(-0,04 \pm 0,05 \%$, de uma média de 1,26 $\pm 0,06 \%$ para $1,22 \pm$ $0,06 \% ; p=0,3 ;$ Figura 41C). No total, $51,2 \%$ dos astrócitos aumentaram a frequência de oscilações de cálcio em baixa glicose, 21,6\% diminuíram a frequência, e $27,2 \%$ não alteraram a frequência (Figura 42C). A proporção de astrócitos incubados em $10 \mathrm{mM}$ de glicose que aumentou a frequência de oscilações de cálcio em baixa glicose foi menor em comparação aos resultados obtidos a partir de $5 \mathrm{mM}$ de glicose (32,1\% vs. 51,2\%, respectivamente; Figura 42C). 
A

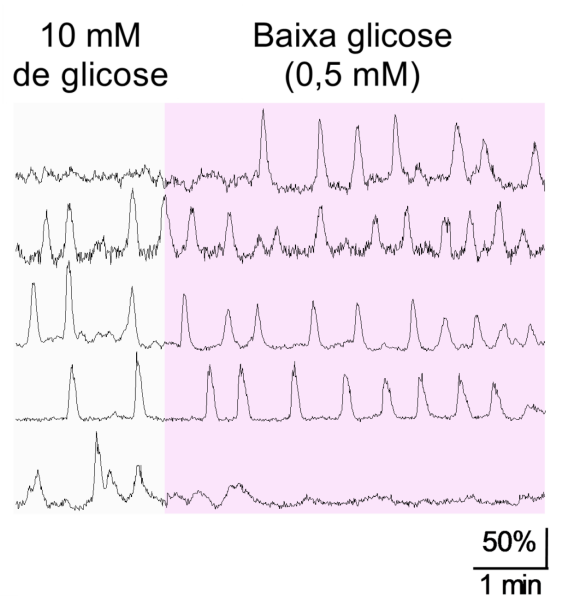

C

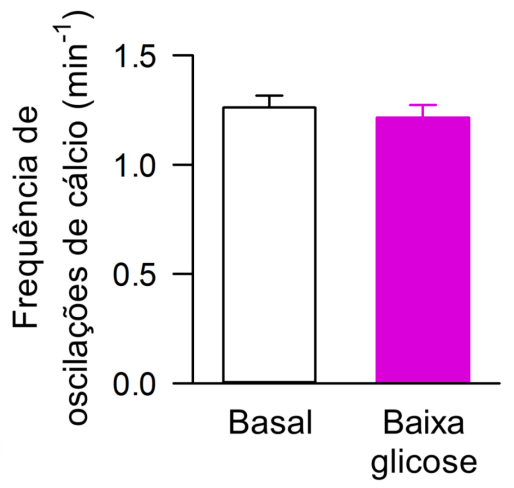

B

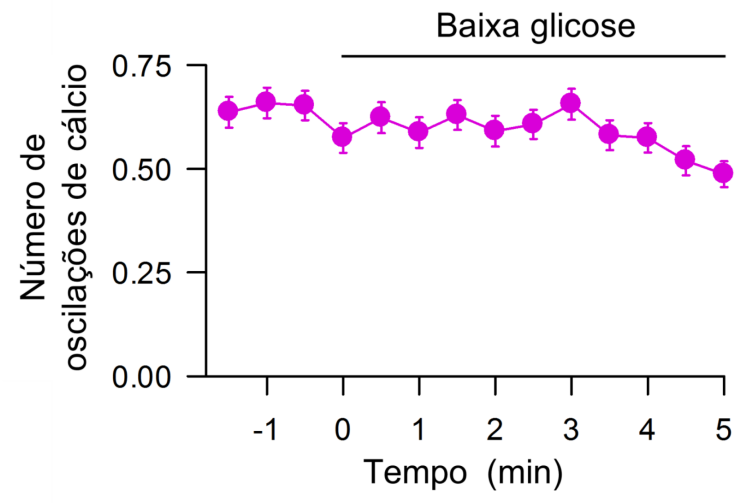

D

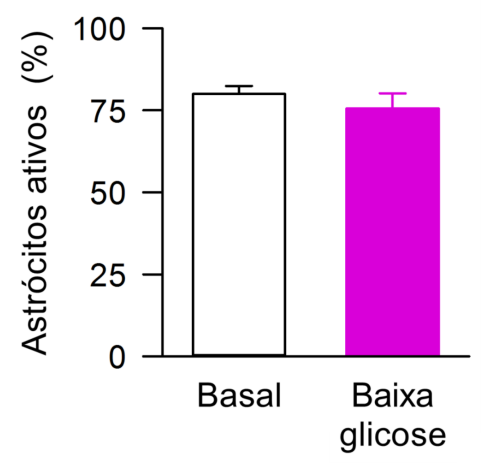

Figura 41. Influência de uma condição hiperglicêmica na sensibilidade à baixa glicose extracelular em astrócitos do NTS. A, traçados representativos mostram a intensidade da fluorescência $\left(\Delta \mathrm{F} / \mathrm{F}_{0}\right)$ adquirida no soma de astrócitos incubados em $10 \mathrm{mM}$ de glicose durante o desafio da baixa glicose. B, número de oscilações de cálcio citosólico em astrócitos incubados em condição hiperglicêmica quando expostos à baixa glicose. C, comparação da frequência das oscilações de cálcio citosólico em resposta à baixa glicose em astrócitos. D, comparação da porcentagem de astrócitos ativos em condição basal e em resposta à baixa glicose.

Interessantemente, observamos aumento na proporção de astrócitos espontaneamente ativos incubados em $10 \mathrm{mM}$ de glicose em comparação aos astrócitos incubados em $5 \mathrm{mM}$ de glicose $(80,0 \pm 2,4 \%$ vs. $44,9 \pm 6,0 \%$, respectivamente; $p<0,0001$; Figura 42A). Além disso, verificamos aumento da frequência basal de oscilações de cálcio em condições hiperglicêmicas quando comparada à solução normoglicêmica $\left(0,32 \pm 0,03 \mathrm{osc}^{\text {min-1 }}\right.$ vs. $1,26 \pm 0,05$ osc $^{\text {min-1 }}$, respectivamente; $p<0,0001$; Figura 42B). 
A

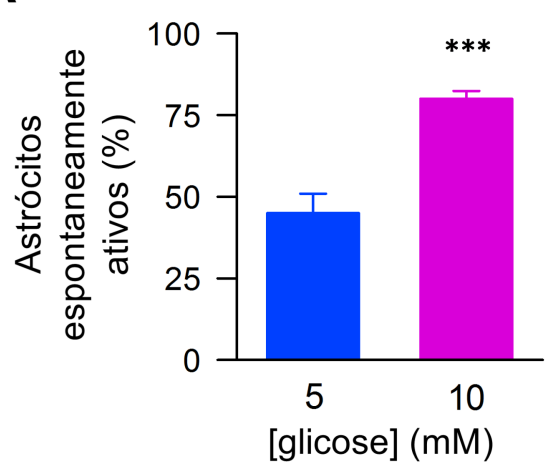

B

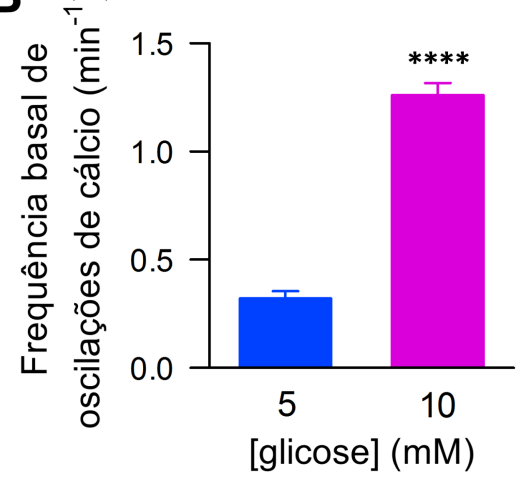

C

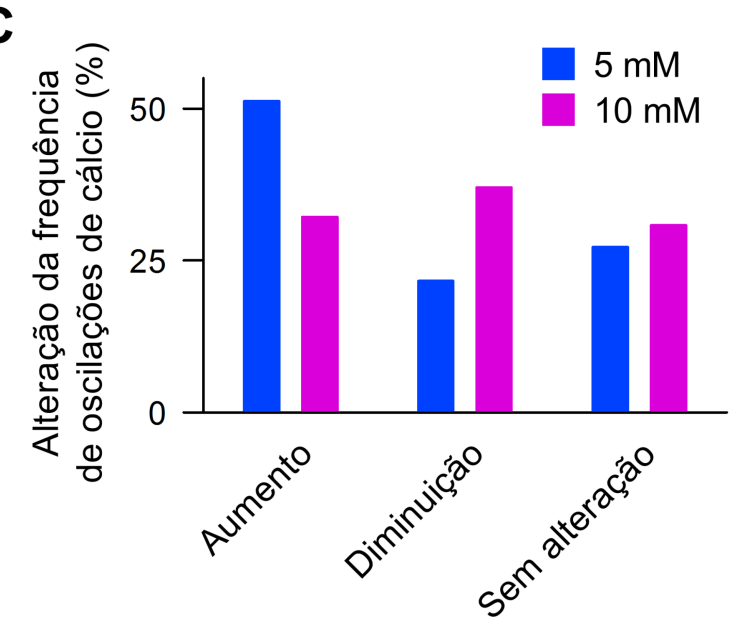

Figura 42. Comparação do efeito da baixa glicose extracelular entre astrócitos do NTS incubados em 5 ou $10 \mathrm{mM}$ de glicose. A, comparação da porcentagem de astrócitos espontaneamente ativos incubados em 5 ou $10 \mathrm{mM}$ de glicose. B, comparação da frequência de oscilações basais de cálcio citosólico entre astrócitos incubados em 5 ou $10 \mathrm{mM}$ de glicose. C, comparação da distribuição dos neurônios de acordo com a alteração da frequência de oscilações de cálcio induzida pela baixa glicose. ${ }^{* * *} p<0,0001$.

A incubação de fatias do tronco encefálico em $10 \mathrm{mM}$ de glicose não resultou em um aumento significativo da frequência SICs neuronais espontâneas ( $n=14$, três animais) em comparação à incubação em $5 \mathrm{mM}$ de glicose $(0,21 \pm 0,10 \mathrm{SICs}$ vs. $0,12 \pm 0,06$, respectivamente; $p=0,4$; Figura 43C), o que sugere que a gliotransmissão glutamatérgica basal não é afetada em condições hiperglicêmicas. Surpreendentemente, a perfusão da baixa glicose aboliu a indução de SICs em neurônios do NTS $(0,21 \pm 0,10 \mathrm{SICs}$, de uma média de $0,21 \pm 0,10$ SICs para 0,00 \pm 0,00 SICs; $p=0,054$; Figura 43A e 43B). No total, nenhum neurônio aumentou a frequência de SICs induzido pela baixa glicose, $28,6 \%$ diminuíram a frequência, e $71,4 \%$ não alteraram a frequência (Figura 43D). 
A

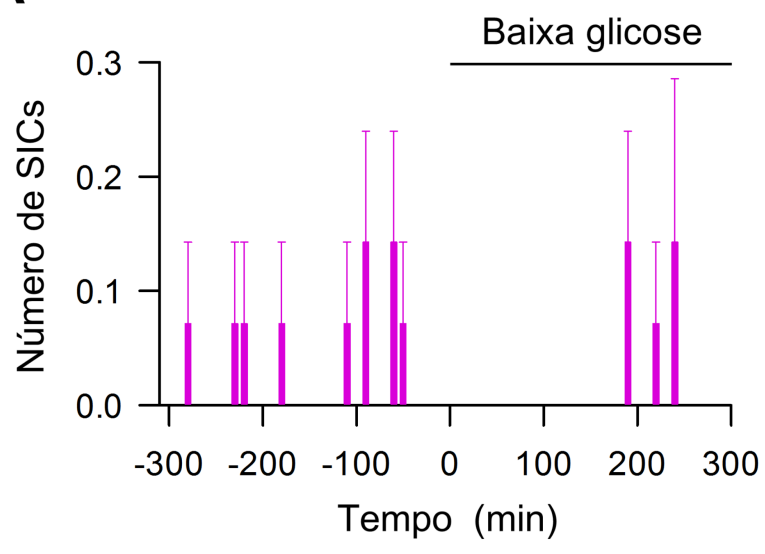

B

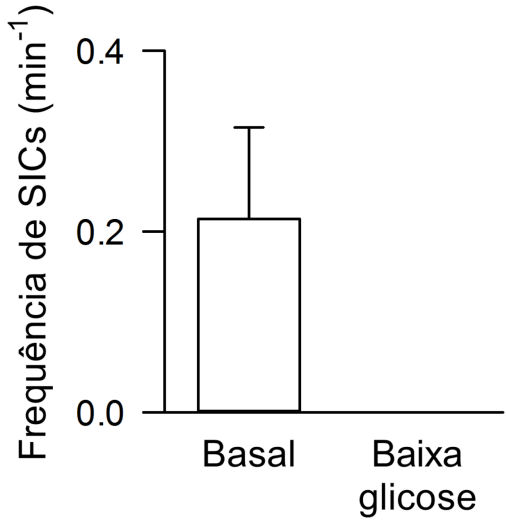

C

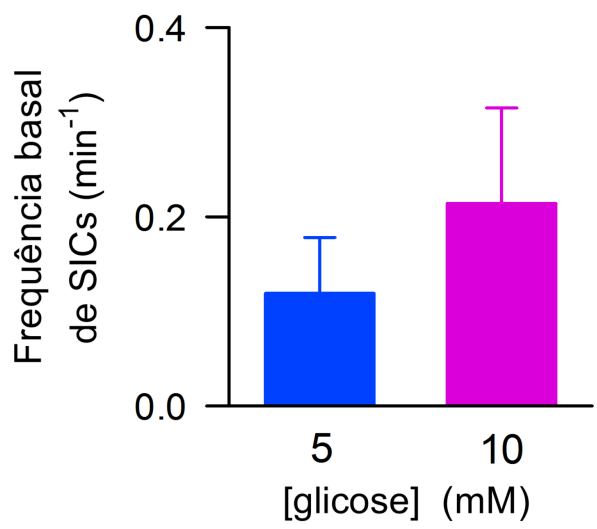

D

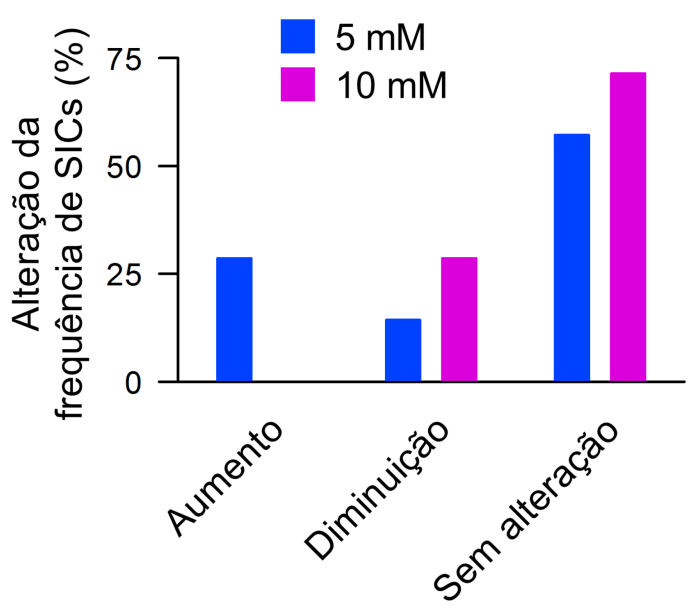

Figura 43. A gliotransmissão glutamatérgica presente no NTS pode ser modulada por alterações da glicose extracelular. A, número de correntes de entrada lentas (SICs) registrados em neurônios incubados em condição hiperglicêmica (10 mM de glicose) em resposta à baixa glicose. B, comparação da frequência de SICs em condição basal e quando expostos à baixa glicose. C, comparação da frequência basal de SIC entre neurônios incubados em 5 e $10 \mathrm{mM}$ de glicose. D, comparação da distribuição dos neurônios de acordo com a alteração da frequência das SICs induzida pela baixa glicose.

Portanto, concluímos que a incubação de astrócitos do NTS em condições hiperglicêmicas aumenta a atividade espontânea de cálcio e o número de astrócitos ativos em comparação a condições normoglicêmicas. Além disso, a sensibilidade à baixa glicose de astrócitos do NTS induzida pela baixa glicose extracelular é comprometida em condições hiperglicêmicas. 
4.3.5. Monitoramento da atividade de cálcio em astrócitos do NTS sob microscopia multifóton

No presente estudo, verificamos que astrócitos do NTS apresentam oscilações espontâneas de cálcio citosólico em condições normoglicêmicas, e que a baixa glicose extracelular pode regular a frequência da atividade de cálcio. Contudo, estes experimentos foram realizados pela obtenção de imagens de cálcio por meio de um indicador de cálcio (Fluo-4-AM) captado pelos astrócitos sob microscopia epifluorescente, o que permite que apenas as flutuações de cálcio medidas no soma sejam quantificadas de modo confiável.

Com o intuito de aprimorar a qualidade dos sinais de cálcio e estudar atividade astrocítica em compartimentos celulares distintos, visamos monitorar as oscilações de cálcio por microscopia multifóton em camundongos transgênicos GFAP-GCaMP6, os quais possuem o indicador de cálcio GCaMP6 geneticamente inserido em astrócitos que expressam GFAP. Confirmamos que os sinais de cálcio eram de fato obtidos de astrócitos por meio da colocalização de SR101 com GCaMP6 em astrócitos do NTS de camundongos GFAP-GCaMP6 (Figura 9).

Adicionalmente, a confirmação da expressão de GCaMP6 em astrócitos do NTS de camundongos GFAP-GCaMP6 foi confirmada por imunofluorescência $(n=6$ fatias, três animais; Figura 44), onde verificamos a colocalização de GCaMP6 e o marcador GFAP (astrócitos), e ausência de colocalização de GCaMP6 e o marcador NeuN (neurônios).
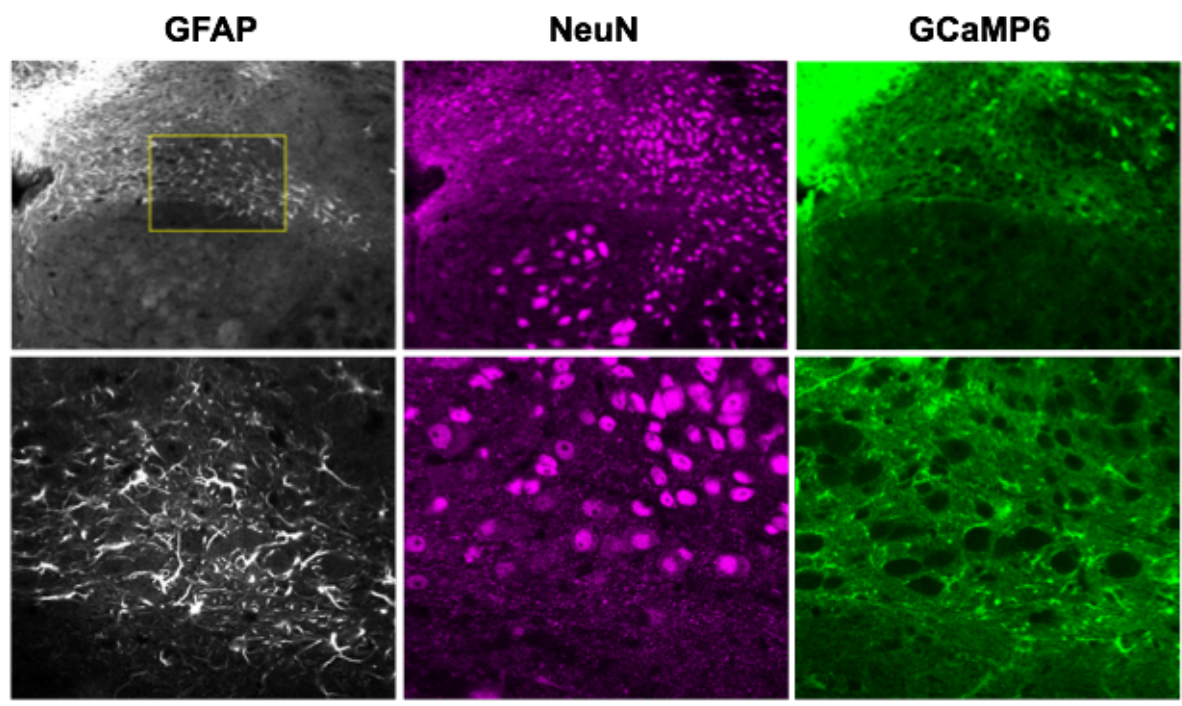

Sobreposição
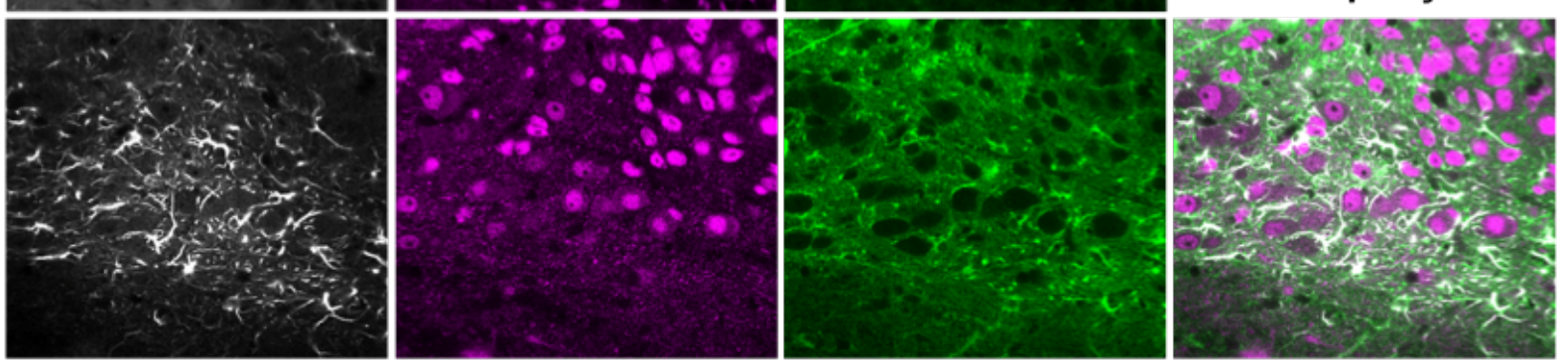

Figura 44. Seletividade da expressão de GCaMP6 em astrócitos do NTS. As imagens representativas obtidas por imunofluorescência mostram a colocalização (à 
direita) de astrócitos (GFAP) com o indicador de cálcio GCaMP6. Note que neurônios (NeuN) não exibem colocalização com GCaMP6.

Ao observar as fatias sob microscopia multifóton, verificamos que astrócitos do NTS exibem atividade espontânea de cálcio no soma e processos em condição normoglicêmica ( $5 \mathrm{mM}$ de glicose; $\mathrm{n}=6$ fatias, 3 animais). A Figura 45 mostra o aumento da intensidade de cálcio no soma e processos de dois astrócitos durante uma oscilação espontânea da sinalização por cálcio em camundongos GFAPGCaMP6.

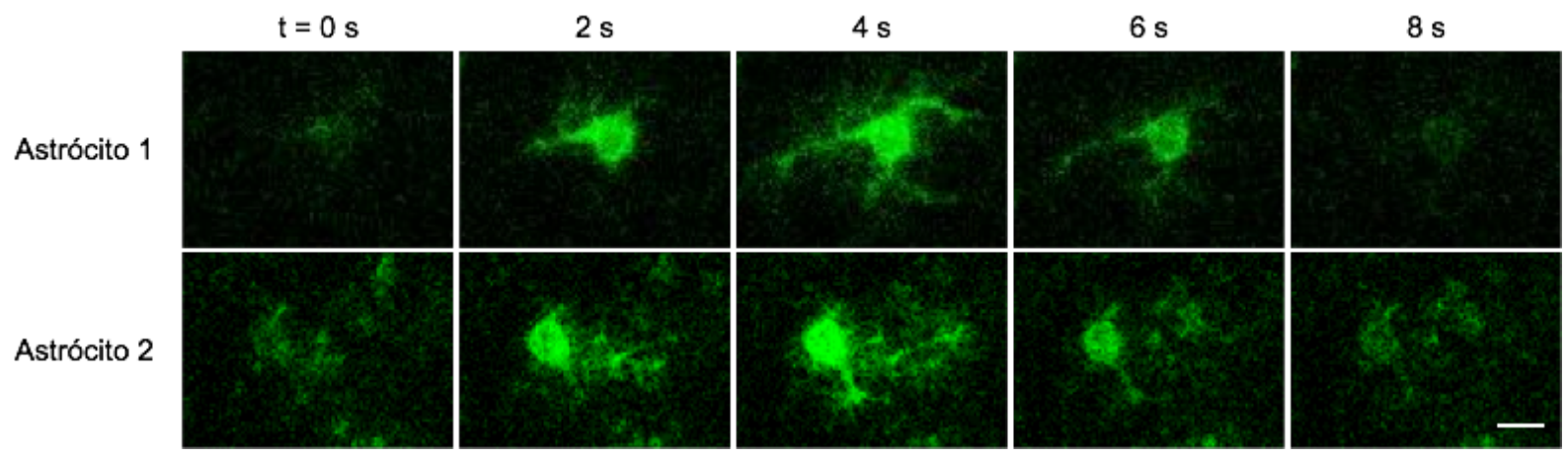

Figura 45. Astrócitos do NTS exibem atividade espontânea de cálcio no soma e processos. As imagens representativas em pseudocor mostram uma oscilação espontânea de cálcio no soma e processos de dois astrócitos sob microscopia multifóton. Os sinais de cálcio foram obtidos em astrócitos de camundongos geneticamente modificados que expressam o indicador de cálcio GCaMP6. Escala horizontal: $10 \mu \mathrm{m}$. 


\section{DISCUSSÃO}

O núcleo do trato solitário (NTS) é uma área que integra informações periféricas e centrais direcionadas a respostas contrarregulatórias à hipoglicemia (Marty et al., 2007; Verberne et al., 2014), e recentes estudos mostram que neurônios e astrócitos do NTS podem responder a flutuações da concentração de glicose no ambiente extracelular (Balfour et al., 2006; McDougal et al., 2013; Boychuk et al., 2015). Na presente investigação, demonstramos que, a partir de uma solução normoglicêmica ( $5 \mathrm{mM}$ de glicose), os canais para potássio sensíveis ao ATP ( $\left.\mathrm{K}_{\mathrm{ATP}}\right)$ são moduladores significativos da sensibilidade à baixa glicose extracelular $(0,5 \mathrm{mM}$ de glicose) em neurônios do NTS, e verificamos que a mobilização interna de cálcio mediada por receptores de inositol 1,4,5-trifosfato tipo $2\left(\mathrm{IP}_{3} \mathrm{R} 2 \mathrm{~s}\right)$ é necessária para a resposta à baixa glicose em astrócitos do NTS. Demonstramos também que uma condição hiperglicêmica (10 mM de glicose) compromete a sensibilidade à baixa glicose extracelular em neurônios e astrócitos do NTS. Além disso, mostramos evidências de comunicação astrócito-neurônio no NTS, a qual pode ser regulada pela concentração de glicose extracelular.

Os desenhos esquemáticos adiante resumem a nossa hipótese acerca da influência do metabolismo celular na sensibilidade à baixa glicose extracelular em neurônios do NTS. A Figura $\mathbf{4 6}$ mostra o mecanismo de resposta à baixa glicose em um neurônio do NTS a partir de uma condição normoglicêmica. Por outro lado, a Figura 47 mostra que uma condição normoglicêmica compromete a resposta de um neurônio do NTS à baixa glicose extracelular.

\subsection{Os canais $K_{\text {ATP }}$ modulam a excitabilidade elétrica e a sensibilidade à baixa glicose extracelular em neurônios do NTS}

Os canais $\mathrm{K}_{\mathrm{ATP}}$ são importantes acopladores da excitabilidade elétrica e status metabólico em neurônios (Nichols, 2006; Hibino et al., 2010), e nós mostramos que estes canais são expressos em neurônios do NTS, pois todos os neurônios hiperpolarizaram em resposta à aplicação de diazoxida, um ativador dos canais $\mathrm{K}_{\text {ATP. }}$. Em condições normoglicêmicas, observamos que a maioria dos canais $K_{\text {ATP }}$ estão abertos em neurônios, visto que a aplicação do bloqueador dos canais $\mathrm{K}_{\mathrm{ATP}}$ tolbutamida induziu despolarização do potencial de repouso da membrana (RMP). Estes resultados mostram que neurônios do NTS possuem canais $\mathrm{K}_{\mathrm{ATP}}$ 
parcialmente abertos no repouso, os quais podem ser regulados pelo metabolismo local (Nichols, 2006). De fato, observamos que os neurônios do NTS estavam com o RMP mais despolarizado e foram menos sensíveis à tolbutamida quando incubamos as fatias em solução contendo alta concentração de glicose, mesmo quando o potencial de membrana foi hiperpolarizado, o que sugere que o RMP mais positivo observado nestes neurônios é devido ao bloqueio dos canais $\mathrm{K}_{\text {ATP }}$ pelo ATP gerado por uma condição hiperglicêmica. Em conjunto, nossos dados mostram que os canais $\mathrm{K}_{\mathrm{ATP}}$ modulam o potencial de membrana via flutuações da razão ATP/ADP metabólica em neurônios do NTS.

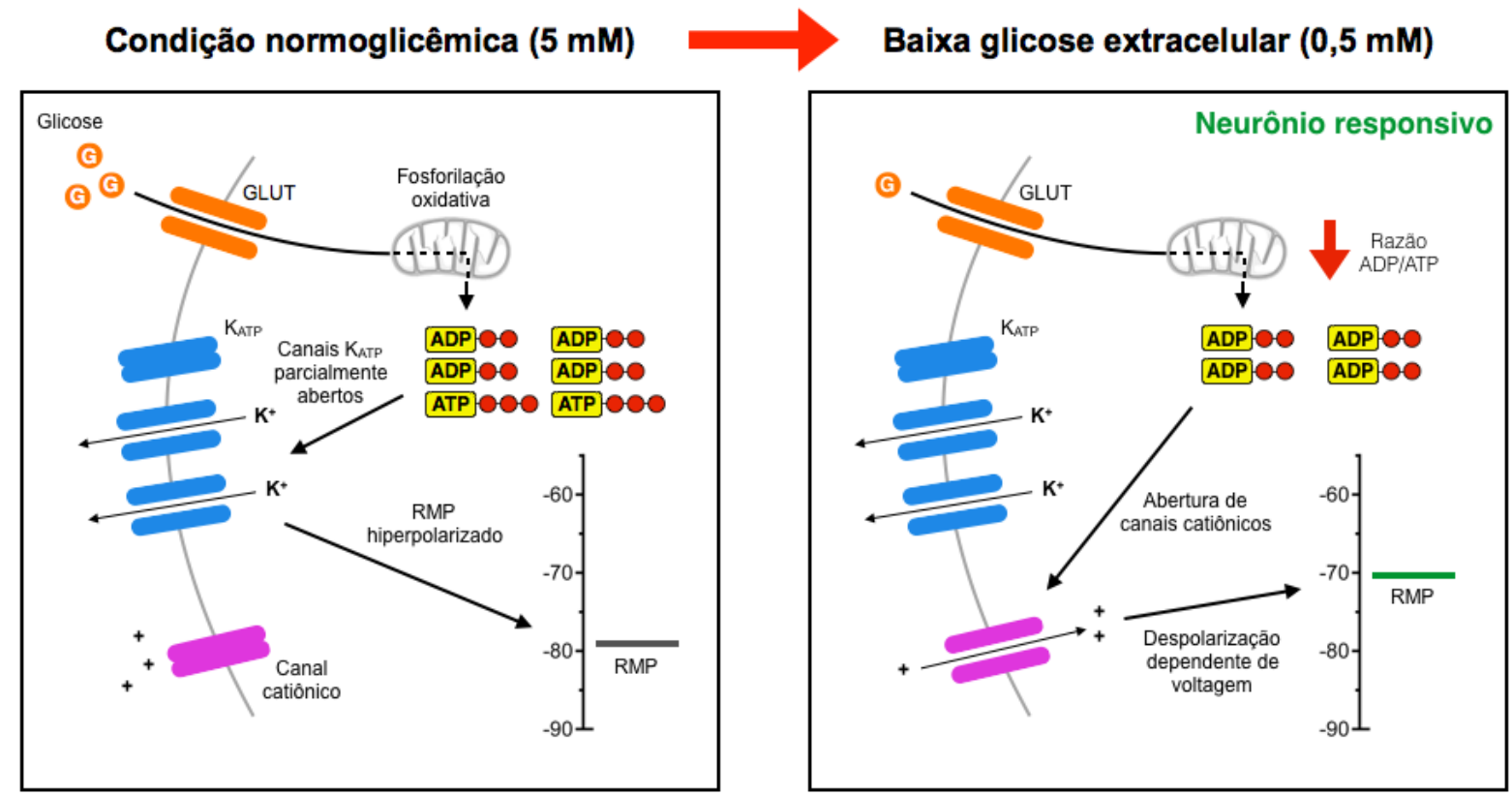

Figura 46. Mecanismo de resposta à baixa glicose extracelular em neurônios do NTS a partir de uma condição normoglicêmica. Em condição normoglicêmica, os canais $\mathrm{K}_{\mathrm{ATP}}$ estão parcialmente abertos na membrana plasmática de neurônios devido à razão ATPIADP citosólica, o que estabelece um potencial de repouso da membrana (RMP) mais hiperpolarizado. Deste modo, a baixa glicose extracelular induz a abertura de uma corrente catiônica por um mecanismo depende de voltagem, o que despolariza o potencial de membrana e gera atividade elétrica no neurônio.

Portanto, nós esperávamos que a despolarização do RMP induzida pela incubação das fatias em uma condição hiperglicêmica poderia levar ao aumento de neurônios não-responsivos à baixa glicose extracelular, pois um RMP mais positivo devido à menor atividade dos canais $\mathrm{K}_{\text {ATP }}$ poderia abolir a resposta do neurônio à baixa glicose, visto que a despolarização do potencial de membrana gerado pelo desafio de baixa glicose é um mecanismo dependente de voltagem. De fato, este 
efeito foi observado. Verificamos que neurônios não-responsivos à baixa glicose corresponderam a 35\% quando incubados em condição normoglicêmica, porém a $70 \%$ quando incubados em condição hiperglicêmica. Interessantemente, a incubação de neurônios do NTS em alta concentração de glicose aumenta o tempo de latência de resposta à baixa glicose, o que indica que a cinética de resposta à baixa glicose é afetada pela concentração de glicose extracelular. Além disso, não observamos despolarização do potencial de membrana induzida pela baixa glicose quando utilizamos $3 \mathrm{mM}$ de glicose na solução de pipeta em nossos registros em whole-cell patch-clamp. Em conjunto, nossos resultados indicam que o status do metabolismo celular é limitante para a sensibilidade à baixa glicose extracelular em neurônios do NTS. Adicionalmente, estes dados mostram que um neurônio do NTS não depende de células adjacentes (neurônios ou glia) para responder à baixa glicose.

\section{Condição hiperglicêmica (10 mM)}

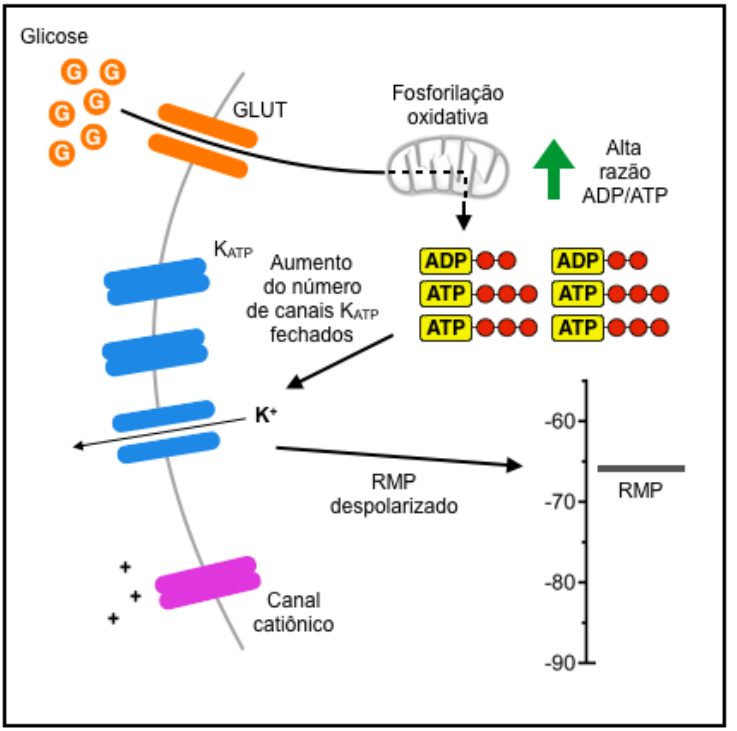

Baixa glicose extracelular $(0,5 \mathrm{mM})$

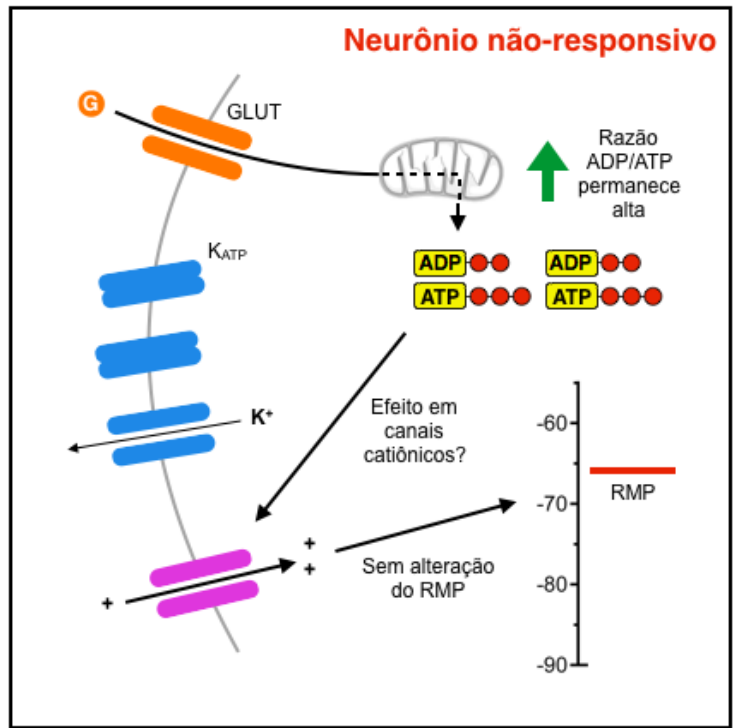

Figura 47. Uma condição hiperglicêmica abole a resposta à baixa glicose extracelular em neurônios do NTS. Em uma condição hiperglicêmica, a alta razão ATP/ADP citosólica induz o fechamento de canais $\mathrm{K}_{\mathrm{ATP}}$, o que estabelece o potencial de repouso da membrana (RMP) de neurônios em um valor mais despolarizado. Deste modo, a despolarização dependente de voltagem desencadeada pela baixa glicose extracelular não é observada, o que leva ao aumento do número de neurônios não-responsivos à diminuição da concentração de glicose externa.

Verificamos que o aumento da razão ATP/ADP citosólica estimulado pela incubação de fatias em condição hiperglicêmica despolariza o RMP de neurônios do 
NTS via fechamento de canais $\mathrm{K}_{\mathrm{ATP}}$, o que abole a resposta despolarizante induzida pela baixa glicose extracelular. Interessantemente, Balfour et al. (2006) reportaram que aproximadamente $80 \%$ de neurônios do NTS e núcleo motor dorsal do vago (DMNX) de ratos não responderam à ausência de glicose no meio extracelular. Entretanto, os registros eletrofisiológicos obtidos por estes autores foram conduzidos utilizando uma solução cerebroespinal artificial (aCSF) controle contendo $10 \mathrm{mM}$ de glicose. Este fato corrobora a nossa hipótese de que o status metabólico de neurônios do NTS influência na excitabilidade elétrica em repouso e compromete a sensibilidade à baixa glicose extracelular.

Adicionalmente, Balfour et al. (2006) mostraram a expressão da subunidade SUR1 dos canais $\mathrm{K}_{\mathrm{ATP}}$ em neurônios que não responderam à baixa glicose, o que indica que os canais $\mathrm{K}_{\mathrm{ATP}}$ estão presentes nestes neurônios mas encontram-se saturados pelo ATP metabólico derivado da alta glicose extracelular. Por outro lado, os canais $\mathrm{K}_{\mathrm{ATP}}$ são canais retificadores de entrada, conduzindo menos corrente para potássio em potencias mais positivo ao potencial de equilíbrio do potássio, ou seja, a ausência de resposta à tolbutamida em neurônios incubados em alta glicose poderia ser causada pelo RMP mais positivo nestes neurônios. Interessantemente, neurônios incubados em condição hiperglicêmica foram capazes de responder à baixa glicose quando hiperpolarizados, porém a magnitude da resposta foi menor em comparação aos neurônios incubados em normoglicemia, o que sugere que outros mecanismos afetam a responsividade de neurônios do NTS à baixa glicose extracelular.

Estudos mostram que a liberação de lactato por astrócitos pode preservar o metabolismo de neurônios em condições de hipoglicemia (Suh et al., 2007; Herzog et al., 2013). Portanto, a geração de lactato induzida por glicogenólise em astrócitos do NTS poderia suprir a demanda de ATP em neurônios adjacentes, o que influenciaria a resposta de neurônios à baixa glicose extracelular. Neste cenário, o efeito da baixa glicose na condutância dos canais $\mathrm{K}_{\mathrm{ATP}}$ em neurônios seria afetado por duas forças opostas: de um lado, a captação de lactato aumentaria a concentração de ATP citosólico (i.e., fechando canais $\mathrm{K}_{\mathrm{ATP}}$ ); por outro lado, a diminuição da concentração de glicose extracelular reduziria a concentração de ATP (i.e., ativando correntes $\mathrm{K}_{\text {ATP }}$ pela menor disponibilidade de glicose). Entretanto, nós observamos que, mesmo após o bloqueio dos canais $\mathrm{K}_{\mathrm{ATP}}$, os neurônios do NTS despolarizavam em resposta à baixa glicose se o potencial de membrana fosse 
hiperpolarizado. Estes dados sugerem que a despolarização induzida pela baixa glicose não é desencadeada pelo fechamento dos canais $\mathrm{K}_{\mathrm{ATP}}$, independente da captação de lactato em neurônios durante um episódio de hipoglicemia.

Apesar da concentração de ATP da solução de pipeta utilizada em nossos experimentos ser maior do que a necessária para bloquear canais $\mathrm{K}_{\mathrm{ATP}}$ compostos pelas subunidades Kir6.2/receptor de sulfonilureia tipo 1 (SUR1) (Baukrowitz et al., 1998), as quais são expressas em neurônios do NTS (Karschin et al., 1997; Balfour et al., 2006; Halmos et al., 2015), o efeito despolarizante da tolbutamida mostra que os canais $\mathrm{K}_{\mathrm{ATP}}$ estão abertos em neurônios mesmo com uma solução interna contendo $4 \mathrm{mM}$ de ATP. Esta observação pode ser explicada pela sensibilidade dos canais $\mathrm{K}_{\text {ATP }}$ à razão ATP/ADP, pois estes canais são ativados por Mg-ADP (Shyng et al., 1997; Nichols, 2006) e a afinidade dos canais $\mathrm{K}_{\text {ATP }}$ ao ATP é bastante reduzida pelo lipídeo de membrana fosfatidilinositol 4,5,-bis-fosfato $\left(\mathrm{PIP}_{2}\right)$ (Baukrowitz et al., 1998; Shyng et al., 2000). Além disso, Balfour et al. (2006) mostraram que neurônios do NTS são mais responsivos ao ATP metabólico em relação ao ATP fornecido pela solução interna, e estudos realizados em neurônios do DMNX (Müller et al., 2002) e neurônios hipotalâmicos (Song et al., 2001) mostram resultados similares. Portanto, nossos registros em whole-cell patch-clamp provavelmente refletem as respostas fisiológicas às alterações da disponibilidade de ATP derivada da glicose extracelular em neurônios do NTS. Adicionalmente, a maior influência do ATP metabólico na atividade dos canais $\mathrm{K}_{\mathrm{ATP}}$ pode também ser resultado da compartimentalização destes canais em domínios específicos na membrana plasmática, os quais estão localizados próximos a mitocôndrias e enzimas glicolíticas (Garg et al., 2009), e mais concentrados em regiões de alta demanda metabólica e alta atividade de transportadores de glicose (Zecchin et al., 2015; Agrawal et al., 2018).

\subsection{A despolarização induzida pela baixa glicose extracelular é um mecanismo dependente de voltagem em neurônios do NTS}

Nós demonstramos que os canais $\mathrm{K}_{\text {ATP }}$ são expressos em neurônios do NTS e encontram-se parcialmente ativos na membrana em condição normoglicêmica. Portanto, esperávamos que a baixa glicose extracelular induziria hiperpolarização do RMP em neurônios devido à diminuição da razão ATP/ADP citosólica e abertura dos

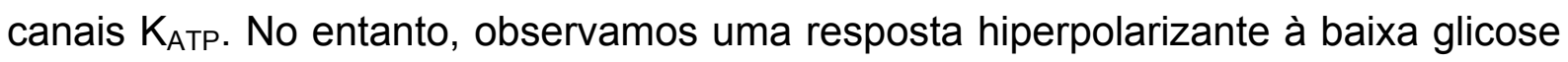
em somente dois de 60 neurônios do NTS em condição normoglicêmica. 
Ao confrontar os dados obtidos, verificamos uma correlação negativa entre a alteração do potencial de membrana induzida pela baixa glicose e o RMP em neurônios, e a mesma correlação foi observada com o efeito da tolbutamida. Interessantemente, outros estudos mostram que nem todos os neurônios do NTS que expressam subunidades dos canais $\mathrm{K}_{\mathrm{ATP}}$ respondem a alterações da concentração de glicose extracelular (Dallaporta et al., 2000; Balfour et al., 2006), o que reforça a ideia de que mecanismos adicionais participam da sensibilidade à baixa glicose em neurônios. Esses dados mostram que tanto a despolarização em resposta à baixa glicose quanto a despolarização induzida pelo bloqueio dos canais $\mathrm{K}_{\mathrm{ATP}}$ são dependentes de voltagem, não sendo observados em neurônios com RMP mais despolarizado.

Estudos mostram que neurônios do NTS podem responder por diferentes mecanismos eletrofisiológicos quando expostos à baixa glicose extracelular. Lamy et al. (2014) reportaram que a baixa glicose induziu fechamento de canais vazantes para potássio em neurônios GABAérgicos do NTS de camundongos, resultando em uma corrente linear não-retificadora. Entretanto, este efeito não é compatível com os nossos achados, pois verificamos que a corrente sensível à baixa glicose extracelular é dependente de voltagem. Interessantemente, estes autores observaram que apenas neurônios que expressam o transportador de glicose independente de sódio tipo 2 (GLUT2) foram responsivos à baixa glicose, o que indica que GLUT2 parece ser um componente necessário para a sensibilidade à baixa glicose extracelular em neurônios do NTS. Além disso, nós observamos diminuição da resistência de entrada da membrana $\left(R_{\text {input }}\right)$ quando os neurônios foram expostos à baixa glicose, o que sugere a abertura de uma condutância de entrada em resposta à diminuição da concentração de glicose extracelular. De fato, verificamos que a baixa glicose extracelular gera uma corrente de entrada catiônica com o potencial de reversão aproximado em $-60 \mathrm{mV}$, o que explica o mecanismo dependente de voltagem induzido pela baixa glicose. No entanto, não observamos correlação entre a amplitude de despolarização induzida pela baixa glicose e a alteração da $R_{\text {input, }} 0$ que sugere que outras condutâncias poderiam ser ativadas pela baixa glicose, como por exemplo a ativação dos canais $\mathrm{K}_{\text {ATP. Interessantemente, }}$ o efeito da tolbutamida também foi dependente de potencial de membrana, o que pode ser explicado pelo fato de que estes canais são retificadores de entrada, não conduzindo bem em potenciais acima do potencial de reversão do potássio. 
Em outro estudo, Balfour \& Trapp (2007) mostraram que a remoção da glicose do meio extracelular gera uma corrente retificadora de entrada em alguns neurônios do NTS, o que poderia contribuir na resposta despolarizante vista em nossos registros. A abertura de canais para cátions ativados por hiperpolarização e nucleotídeo cíclico $(\mathrm{HCN})$, os quais medeiam a corrente catiônica denominada $\mathrm{h}$, poderia ser uma explicação para os nossos resultados; entretanto, a ativação da corrente induzida pela baixa glicose extracelular é muito rápida, o que não é compatível com a ativação lenta dos canais HCN. Nós realizamos ensaios experimentais com o antagonista dos canais HCN ZD27888 (10 $\mu \mathrm{M})$, mas os resultados foram inconclusivos devido à despolarização progressiva do potencial de membrana causada por este fármaco, mascarando assim o efeito da baixa glicose extracelular. No hipotálamo ventromedial, a baixa glicose leva ao fechamento de canais para cloreto e despolarização do potencial de membrana em alguns neurônios (Routh et al., 2014), porém o potencial de reversão da corrente induzida pela baixa glicose em nossos experimentos não sugere uma condutância para cloreto.

Além de canais iônicos, outros mecanismos podem contribuir para a despolarização neuronal frente à baixa disponibilidade de glicose no ambiente extracelular. As bombas eletrogênicas $\mathrm{Na}^{+} / \mathrm{K}^{+}$-ATPase, por exemplo, são importantes geradoras do gradiente eletroquímico nas células. Estudos mostram que a alta concentração de glicose extracelular estimula a bomba $\mathrm{Na}^{+} / \mathrm{K}^{+}$-ATPase e desencadeia hiperpolarização em neurônios excitados por glicose no hipotálamo lateral (Oomura et al., 1974). Adicionalmente, a hipoglicemia cerebral reduz a atividade da bomba $\mathrm{Na}^{+} / \mathrm{K}^{+}$-ATPase (Lees, 1991) e pode induzir despolarização do potencial de membrana (Balfour \& Trapp, 2007). Então, a redução da atividade da bomba $\mathrm{Na}^{+} / \mathrm{K}^{+}$-ATPase poderia ser um componente adicional que alteraria o RMP de neurônios do NTS em resposta à baixa glicose extracelular. Contudo, mais uma vez, este mecanismo de despolarização não é compatível com a dependência de voltagem e a diminuição da $R_{\text {input }}$ observadas nas respostas de neurônios em nossos registros.

Portanto, a literatura mostra que neurônios do NTS responsivos à baixa glicose extracelular apresentam mecanismos heterogêneos de resposta, diferentemente de neurônios excitados por glicose, os quais utilizam o bloqueio dos canais $\mathrm{K}_{\mathrm{ATP}}$ como o principal mecanismo de indução para o disparo da atividade 
elétrica em resposta ao aumento da concentração de glicose extracelular (Dallaporta et al., 2000; Boychuk et al., 2015). Este fato até que não é surpreendente, pois diversas vias de sinalização devem ser ativadas em uma condição de privação energética, como a baixa disponibilidade de glicose, pois o ambiente extracelular não apresenta condições fisiológicas saudáveis para a sobrevivência celular. Ao contrário da hiperglicemia, a qual desenvolve neuropatias ao longo dos anos, a hipoglicemia cerebral pode comprometer a atividade neuronal em poucos minutos (Cryer, 2007; Mergenthaler et al., 2013).

Pelo fato do fechamento dos canais $\mathrm{K}_{\mathrm{ATP}}$ e da baixa glicose extracelular induzirem despolarização do potencial de membrana, mas a glicose ser ineficaz em despolarizar neurônios quando os canais $\mathrm{K}_{\mathrm{ATP}}$ estão completamente bloqueados (sem a hiperpolarização artificial do potencial de membrana), nós acreditamos que a despolarização induzida pela glicose extracelular possa representar um mecanismo de regulação homeostática do RMP. Deste modo, o potencial de membrana não seria excessivamente hiperpolarizado em decorrência da abertura dos canais $\mathrm{K}_{\mathrm{ATP}}$ durante um episódio de hipoglicemia, o que poderia ser essencial para manter as funções autonômicas vitais mediadas pelo NTS. No entanto, quando os neurônios foram expostos à baixa glicose por mais de 20 minutos, nós observamos uma hiperpolarização que pôde ser inibida pela aplicação de tolbutamida, o que indica uma resposta neuroprotetora (Nichols, 2006). Estes resultados mostram que a despolarização induzida pela baixa glicose extracelular não é mantida por longos períodos em neurônios do NTS, pois o potencial de membrana é hiperpolarizado provavelmente em resposta à diminuição da razão ATP/ADP metabólico. Mesmo assim, observamos que o potencial de membranas nestes neurônios se mantém em valores acima ou próximos do potencial de repouso por muito tempo, não hiperpolarizando como observado pela ativação dos canais KATP em resposta à aplicação de diazoxida. Estes resultados sugerem que a despolarização induzida pela baixa glicose extracelular impede que estes neurônios hiperpolarizem demais por um longo tempo, o que poderia comprometes as atividades vitais do NTS.

\subsubsection{A influência da idade na sensibilidade à baixa glicose extracelular}

No presente estudo, utilizamos ratos com idades diferentes $(3,6$ e 11 semanas) no decorrer dos experimentos. Surpreendentemente, observamos que a proporção de neurônios do NTS responsivos à baixa glicose e à tolbutamida estava 
menor em fatias de animais com 11 semanas de idade em comparação a animais com 3 e 6 semanas de idade. Os neurônios não-responsivos de animais com 11 semanas de idade também estavam mais despolarizados quando comparados aos neurônios responsivos, assim como observado em fatias de animais mais jovens. Tendo em vista que a despolarização induzida pela baixa glicose ou tolbutamida foi similar entre neurônios responsivos de animais com 3 e 11 semanas de idade, nós acreditamos que esta diferença seja ocasionada pelo RMP mais positivo em neurônios de animais com 11 semanas de idade, resultando no maior número de neurônios do NTS responsivos à baixa glicose extracelular em animais mais jovens, visto que o efeito despolarizante induzido pela baixa glicose extracelular é dependente de voltagem.

Novos estudos são necessários para elucidar a razão para a diferença do RMP em neurônios do NTS, o que poderia estar relacionado a alterações do desenvolvimento do animal. Ratos com 3 semanas de idade estão em estágio de amamentação, os quais têm acesso ao leite materno altamente calórico, enquanto ratos com 11 semanas de idade são animais jovens adultos que se alimentam de ração padrão. As diferenças na ingestão calórica, tipos de alimento e comportamento relacionado à alimentação podem levar a estados metabólicos distintos, e portanto a alterações em propriedades eletrofisiológicas passivas e na atividade dos canais $\mathrm{K}_{\mathrm{ATP}}$ em neurônios do NTS. Interessantemente, o estudo realizado por Balfour et al. (2006), que reportou que apenas $20 \%$ de neurônios do NTS incubados em condição hiperglicêmica respondem à remoção da glicose extracelular, foi conduzido em fatias do tronco encefálico de animais com 3-4 semanas de idade. Estes dados corroboram a nossa hipótese de que a menor responsividade à baixa glicose observada por estes autores é devido à saturação dos canais $\mathrm{K}_{\mathrm{ATP}}$, pois verificamos que a resposta à baixa glicose extracelular foi majoritariamente induzida em neurônios de animais com a mesma idade em nossos experimentos.

\subsection{A sinalização por $I_{3} R 2$ modula a atividade de cálcio citosólico em resposta à baixa glicose extracelular em astrócitos do NTS}

Devido à organização da citoarquitetura celular, alta expressão de enzimas glicolíticas e capacidade de armazenar glicogênio, os astrócitos têm ganhado destaque na regulação da homeostase da glicose (Stobart \& Anderson, 2013; 
Magistretti \& Allaman, 2015; García-Cáceres et al., 2019). No presente estudo, verificamos que astrócitos do NTS também podem responder a variações da concentração de glicose extracelular, pois observamos que astrócitos apresentam atividade espontânea de cálcio em condição normoglicêmica, e a baixa glicose extracelular altera a frequência de oscilações de cálcio citosólico na maioria dos astrócitos. Demonstramos também que a baixa glicose induz aumento do número de astrócitos ativos, o que mostra a presença de astrócitos silentes no NTS em condição normoglicêmica que são ativados pela baixa disponibilidade energética no ambiente extracelular. Além disso, a incubação de fatias do tronco encefálico em condição hiperglicêmica induz aumento do número de astrócitos que exibem atividade espontânea de cálcio e eleva a frequência de oscilações espontâneas de cálcio citosólico em astrócitos do NTS. Portanto, mostramos que a atividade de cálcio em astrócitos do NTS pode ser regulada por alterações da concentração de glicose extracelular.

Outras evidências sugerindo que a baixa glicose extracelular poderia induzir resposta em astrócitos do NTS já haviam sido observadas (McDougal et al., 2013; Rogers et al., 2018). Em ambos os estudos, os autores verificaram que condições hipoglicêmicas podem aumentar ou diminuir o sinal de cálcio em astrócitos do NTS, sendo este efeito mantido durante toda a perfusão da solução contendo baixa glicose. Apesar da duração de uma oscilação de cálcio ser longa, as cinéticas dos sinais de cálcio obtidos por estes autores foram similares entre astrócitos e neurônios, e estudos mostram que a duração de uma oscilação de cálcio em neurônio é muito rápida (Grienberger \& Konnerth, 2012). Portanto, estes resultados não parecem refletir a atividade de cálcio fisiológica em astrócitos, a qual baseia-se em picos de cálcio (Rusakov, 2015), assim como demonstram estudos in vivo em roedores (Martín et al., 2015; Poskanzer \& Yuste, 2016) e estudos in vitro em tecido cerebral de humanos (Navarrete et al., 2013). Na presente investigação, mostramos de fato que a sinalização de cálcio pode ser regulada pela disponibilidade de glicose extracelular em astrócitos do NTS.

O aumento da atividade de cálcio poderia ser explicado por alguns mecanismos. Por exemplo, estudos mostram que a remoção de glicose do meio extracelular pode inibir a atividade de bombas cálcio-ATPase em retículos endoplasmáticos de astrócitos (Kahlert \& Reiser, 2000; Arnold, 2005). Interessantemente, astrócitos do NTS GLUT2 $^{+}$respondem a condições 
hipoglicêmicas (Marty et al., 2005), e portanto a depleção de glicose no ambiente extracelular poderia direcionar o fluxo de glicose para o meio externo e contribuir para o esgotamento de substrato energético para a via glicolítica em astrócitos, o que levaria à inatividade de bombas cálcio-ATPase e mobilização do cálcio reticular para o citosol. Além disso, receptores de rianodina (Sharma \& Vijayaraghavan, 2001), canais de receptor de potencial transiente (TRPs) (Shigetomi et al., 2011), canais para cálcio do tipo-L (Cheli et al., 2016), trocadores $\mathrm{Na}^{+} / \mathrm{Ca}^{2+}$ (Blaustein et al., 2002) e mitocôndrias (Agarwal et al., 2017) também podem atuar na regulação da atividade de cálcio em astrócitos.

No entanto, verificamos que o aumento de cálcio citosólico em resposta à baixa glicose extracelular depende da via de sinalização $\mathrm{IP}_{3} \mathrm{R} 2$ na maioria dos astrócitos do NTS, pois não observamos alteração da frequência de oscilações de cálcio induzida pela baixa glicose na maior proporção dos astrócitos nem aumento do número de astrócitos ativos. Estes dados corroboram outros estudos que indicam que a mobilização interna de cálcio mediada por $I_{3} R 2$ em retículos endoplasmáticos é crucial para a resposta de astrócitos a outros estímulos (Vaarmann et al., 2010; Paukert et al., 2014), particularmente os induzidos pela ativação de receptores acoplados à proteína G (GPCRs) (Di Castro et al., 2011; Durkee et al., 2019). Portanto, embora outros mecanismos possam atuar na sinalização de cálcio em astrócitos, o que poderia explicar a alteração da frequência de oscilações de cálcio observada em alguns astrócitos do NTS de animais $\mathrm{IP}_{3} \mathrm{R} 2^{-/-}$ em resposta à baixa glicose, nossos dados indicam que a sinalização por $I P_{3} R 2$ é fundamental para a sensibilidade à baixa glicose extracelular em astrócitos do NTS.

Nossos resultados mostraram que uma pequena proporção de astrócitos do NTS de animais $\mathrm{IP}_{3} \mathrm{R} 2^{-/-}$apresentam atividade de cálcio basal, com menor frequência de oscilações de cálcio em comparação aos animais controle, o que mostra que a atividade espontânea de cálcio no corpo celular de astrócitos do NTS em condição normoglicêmica requer a participação de $I P_{3} R 2$. Como a construção transgênica knockout de animais $\mathrm{IP}_{3} \mathrm{R} 2^{-/-}$foi realizada em um estágio de desenvolvimento precoce, é possível que a circuitaria neuronal tenham se adaptado à ausência de sinalização de cálcio em astrócitos. Interessantemente, animais $\mathrm{IP}_{3} \mathrm{R} 2^{-/-}$parecem não apresentar deficiências motoras, sensoriais ou cognitivas (Petravicz et al., 2014), o que corrobora publicações que mostram que alguns mecanismos de neurotransmissão não são afetados nestes animais (Fiacco et al., 
2007; Petravicz et al., 2008). Por outro lado, outros estudos demonstram que a transmissão sináptica e plasticidade podem estar comprometidas em animais $\mathrm{IP}_{3} \mathrm{R}^{-}$ I- (Navarrete et al., 2012; Yang et al., 2016), as quais poderiam ter implicações em deficiências comportamentais (Oliveira et al., 2015; Martin-Fernandez et al., 2017). Portanto, estudos subsequentes são necessários para elucidar a importância fisiológica da sinalização $\mathrm{IP}_{3} \mathrm{R} 2$ na atividade de cálcio em astrócitos do NTS.

A utilização do indicador de cálcio Fluo-4-AM em conjunto com o marcador de astrócitos sulforodamina (SR101) mostrou-se bastante eficaz para a análise da atividade de cálcio no soma de astrócitos do NTS em nossos experimentos. Entretanto, estudos mostram que a sinalização de cálcio ocorre em diferentes compartimentos, como em processos astrocíticos, nos quais a difusão de Fluo-4-AM é limitada devido ao pequeno volume espacial (Reeves et al., 2011). Além disso, imagens obtidas pelos sinais de cálcio em processos astrocíticos sob microscopia epifluorescente não possuem resolução suficiente para uma quantificação segura da atividade de cálcio nestes compartimentos (Shigetomi et al., 2010b; Shigetomi et al., 2013). Portanto, realizamos imagens de cálcio em astrócitos do NTS de animais GFAP-GCaMP6 sob microscopia multifóton, o que nos permitiu aumentar a intensidade dos sinais de cálcio em astrócitos e aprimorar a qualidade das oscilações de cálcio em compartimentos astrocíticos distintos. Embora ainda não quantificado, verificamos que astrócitos do NTS apresentam oscilações espontâneas de cálcio no soma e processos astrocíticos em condição normoglicêmica, e notamos que a baixa glicose extracelular aumenta a frequência das oscilações de cálcio em ambos os compartimentos. Estes dados confirmariam nossos resultados obtidos com Fluo-4-AM, e mostrariam que a baixa glicose poderia também modular a atividade de cálcio em processos astrocíticos, os quais são estruturas que formam a arborização astrocítica e que de fato possuem extenso contato com estruturas neuronais (Barros, 2013; Allen \& Eroglu, 2017).

No presente estudo, demonstramos que astrócitos do NTS apresentam aumento do número de astrócitos espontaneamente ativos e elevação da frequência de oscilações de cálcio basal quando incubados em condição hiperglicêmica. Concomitantemente, mostramos que neurônios do NTS apresentam RMP mais despolarizado nesta mesma condição, o que poderia levar à maior probabilidade de liberação de vesículas contendo neurotransmissores no espaço intersticial, como o glutamato. Portanto, levantamos a hipótese de que, em condição hiperglicêmica, o 
aumento da atividade de cálcio basal em astrócitos do NTS poderia ser causada pelo aumento da concentração de glutamato no ambiente extracelular. Deste modo, - glutamato liberado por neurônios poderia ativar receptores glutamatérgicos metabotrópicos em astrócitos e induzir aumento da atividade de cálcio (Rusakov et al., 2011; Araque et al., 2014), os quais poderiam liberar ATP para o meio extracelular e ativariam receptores purinérgicos em astrócitos adjacentes, causando a propagação do sinal de cálcio (Guthrie et al., 1999; Hamilton et al., 2008). Interessantemente, condições hiperglicêmicas induzem elevação da concentração de ATP citosólico em astrócitos (Li et al., 2018), o que aumentaria a disponibilidade de ATP para ativar astrócitos vizinhos.

Astrócitos são células altamente glicolíticas (Belanger et al., 2011), e este cenário de alta disponibilidade de ATP metabólico em astrócitos incubados em condição hiperglicêmica poderia explicar a diminuição do número de astrócitos do NTS sensíveis à baixa glicose extracelular observada em nossos experimentos, similarmente ao verificado em neurônios. A alta disponibilidade de glicose extracelular aumenta a taxa de glicogênese em astrócitos ( $\mathrm{Li}$ et al., 2018), e a glicogenólise pode ser estimulada em condições hipoglicêmicas para suprir a demanda de ATP metabólico (Suh et al., 2007; Oz et al., 2009). Portanto, acreditamos que o aumento do metabolismo intracelular da glicose em astrócitos incubados em condição hiperglicêmica possa mascarar a detecção da baixa glicose extracelular e diminuição da concentração de ATP citosólico. Contudo, estes mecanismos ainda precisam ser investigados.

\subsection{Evidências de gliotransmissão regulada pela concentração de glicose extracelular no NTS}

Visto que a baixa glicose extracelular modula a atividade de cálcio em astrócitos e excitabilidade elétrica em neurônios do NTS, nos perguntamos se astrócitos poderiam sinalizar neurônios adjacentes em resposta à baixa glicose. Verificamos a presença de correntes de entrada lentas (SICs) em neurônios do NTS em condição normoglicêmica, as quais são geradas pela ativação de receptores $\mathrm{N}$ metil-D-aspartato (NMDARs) extrassinápticos por moléculas de glutamato liberadas por astrócitos (Fellin et al., 2004; Haydon \& Carmignoto, 2006). De fato, as SICs foram bloqueadas pela aplicação do ácido D-2-amino-5-fosfonopentanoico (DLAP5), um antagonista de NMDARs. Importantemente, observamos que a baixa glicose 
extracelular aumenta a frequência de SICs em alguns neurônios do NTS simultaneamente ao aumento da frequência de oscilações de cálcio em astrócitos adjacentes, sugerindo que o aumento da atividade de cálcio em astrócitos esteja correlacionada à geração de SICs neuronais, i.e., gliotransmissão por glutamato. O fato de não termos observado a presença de SICs em neurônios do NTS de animais $\mathrm{IP}_{3} \mathrm{R} 2^{-/-}$em condição normo- ou hipoglicêmica reforça a ideia de que a geração de SICs em neurônios do NTS depende da atividade de cálcio em astrócitos vizinhos. Em conjunto, nossos dados indicam a existência de comunicação astrócito-neurônio via glutamato no NTS, a qual pode ser regulada pela concentração de glicose extracelular.

Em condições de baixa disponibilidade energética, como na isquemia cerebral, a inatividade das bombas $\mathrm{Na}^{+} / \mathrm{K}^{+}$-ATPase pode induzir aumento do volume celular astrocítico (Song \& Yu, 2014). Curiosamente, a baixa glicose extracelular compromete o acoplamento de gap-junctions em astrócitos, o que leva ao inchaço celular e induz aumento da concentração de cálcio citosólico (Lee et al., 2016). Além disso, Yang et al. (2019) demonstrou que canais aniônicos regulados por volume (VRACs) podem mediar a liberação de glutamato em resposta ao aumento do volume astrocítico, resultando na geração de SICs em neurônios adjacentes. Estes dados sugerem que a diminuição da concentração de glicose extracelular quebra o gradiente eletroquímico em astrócitos do NTS, resultando no aumento da atividade de cálcio e liberação de glutamato via canais VRAC, o que poderia explicar a gliotransmissão glutamatérgica induzida pela baixa glicose observada em nossos experimentos.

Outras evidências indicam que a glicoprivação pode induzir gliotransmissão via ATP no NTS. A remoção de glicose no ambiente extracelular estimula glicogenólise em astrócitos (Suh et al., 2007), o que leva ao aumento da geração de ATP citosólico. Adicionalmente, a privação de glicose eleva a concentração de ATP no meio extracelular em astrócitos em cultura (Liu et al., 2008) e fatias do hipocampo (Jurányi et al., 1999). Portanto, estes dados mostram que a depleção energética extracelular pode induzir a liberação de ATP por astrócitos. De fato, Rogers et al. (2018) mostraram que antagonistas de receptores purinérgicos inibe o aumento da concentração de cálcio citosólico em resposta à glicoprivação em neurônios do NTS, mas não em astrócitos vizinhos. Em conjunto, estes estudos sugerem que glutamato e/ou ATP podem atuar como gliotransmissores em respostas induzidas pela 
depleção de glicose no ambiente extracelular no NTS, embora novos estudos são necessários para elucidar a importância fisiológica da comunicação astrócitoneurônio envolvida no controle do balanço energético.

\subsection{Implicações fisiológicas da sensibilidade à baixa glicose extracelular em astrócitos e neurônios do NTS}

No presente estudo, mostramos que, a partir de uma condição normoglicêmica, a perfusão de uma solução aCSF contendo baixa glicose induz alterações da excitabilidade elétrica na maioria de neurônios e modula a atividade de cálcio na maioria de astrócitos do NTS. Estes efeitos são mantidos na presença de tetrodotoxina, o que mostra que a sensibilidade à baixa glicose em astrócitos e neurônios do NTS não depende da influência da circuitaria neuronal, e que de fato as respostas observadas em nossos experimentos foram decorrentes do efeito per se da baixa glicose nas células. Além disso, a incubação das fatias em condição hiperglicêmica despolariza o RMP em neurônios, enquanto em astrócitos aumenta a frequência de oscilações espontâneas de cálcio e o eleva o número de astrócitos ativos. Portanto, nossos dados mostram que a atividade celular pode ser regulada por alterações da concentração de glicose extracelular em uma grande proporção de neurônios e astrócitos do NTS.

O alto número de células do NTS sensíveis à disponibilidade de glicose extracelular observada em nossos experimentos vai ao encontro de outros achados na literatura, os quais reportam que $56-68 \%$ de neurônios não-identificados do NTS de ratos foram sensíveis a flutuações da concentração de glicose extracelular (Dallaporta et al., 2000; Himmi et al., 2001; Mimee \& Ferguson, 2015), e que 52-74\% dos astrócitos do NTS de ratos responderam a condições hipoglicêmicas (McDougal et al., 2013; Rogers et al., 2018). Em conjunto, estes resultados sugerem que o NTS é uma área bastante sensível a flutuações da concentração de glicose no espaço intersticial. A alta densidade de capilares fenestrados no NTS (Gross et al., 1990) e a localização do NTS próxima ao quarto ventrículo (Barraco et al., 1992) mostram o potencial do NTS em conter células sensíveis a sinais metabólicos circulantes, como a glicose. Afinal, a glicose é o principal precursor energético para o organismo, principalmente ao cérebro (Mergenthaler et al., 2013), e glicossensores presentes no NTS poderiam desempenhar um papel significativo no controle neural do 
metabolismo, tendo em vista a importância do NTS para a regulação da glicose circulante (Marty et al., 2007; Verberne et al., 2014).

Nossos resultados claramente mostram mecanismos de detecção à rápida diminuição da baixa glicose extracelular em astrócitos e neurônios do NTS, o que poderia ser potencialmente relevante para respostas neurometabólicas à hipoglicemia. Pacientes portadores de diabetes tipo I e avançadas tipo II comumente apresentam uma condição denominada deficiência autonômica associada à hipoglicemia, a qual é caracterizada pela atenuação de respostas contrarregulatórias à hipoglicemia, e pode levar os pacientes a um estado de incapacidade de detectar quando irão entrar em uma condição hipoglicêmica (Cryer, 2005). Estudos indicam que esta deficiência é causada por episódios subsequentes de hipoglicemia devido a intervenções de insulina, os quais habituariam o cérebro a aumentar o aporte de glicose circulante e/ou utilizar substratos energéticos alternativos, como lactato e derivados de ácidos graxos (McNay \& Cotero, 2010; Litvin et al., 2013). Entretanto, se por um lado estas adaptações neuroprotetoras mantêm a atividade neural durante uma condição hipoglicêmica, por outro lado pode atenuar a sensibilidade à baixa glicose extracelular no ambiente cerebral. De acordo, neurônios sensíveis à glicose do hipotálamo ventromedial apresentam resposta amenizada após injeções repetitivas de insulina (Song \& Routh, 2006).

Em outras palavras, o cérebro se adapta para utilizar preferencialmente outros substratos energéticos à glicose para suprir sua demanda energética em condições de hipoglicemia, mas acaba por não detectar uma diminuição da concentração de glicose no espaço intersticial. Interessantemente, a aplicação de lactato pode afetar negativamente a sensibilidade à baixa glicose extracelular em neurônios do NTS (Himmi et al., 2001). Portanto, nossos dados sugerem que o estabelecimento de um RMP mais despolarizado devido ao fechamento de canais $\mathrm{K}_{\text {ATP }}$ em neurônios do NTS, em conjunto com o aumento da atividade espontânea de cálcio em astrócitos do NTS, poderiam ser mecanismos adicionais que contribuiriam para a redução da sensibilidade a flutuações glicêmicas em pacientes com deficiência autonômica associada à hipoglicemia. 
CONCLUSÕES 


\section{CONCLUSÕES}

Conforme os dados obtidos no presente estudo, concluímos que:

1. A concentração de glicose extracelular regula a atividade de uma grande proporção de neurônios e astrócitos do NTS;

2. Em condição normoglicêmica, a maioria dos neurônios do NTS despolariza em resposta à baixa glicose extracelular por um mecanismo depende de voltagem;

3. Os canais para potássio sensíveis ao ATP ( $\left.\mathrm{K}_{\mathrm{ATP}}\right)$ controlam o potencial de repouso da membrana e modulam a sensibilidade à baixa glicose extracelular em neurônios do NTS;

4. Astrócitos do NTS apresentam atividade espontânea de cálcio no soma e processos astrocíticos;

5. A baixa glicose extracelular aumenta a frequência de oscilações de cálcio citosólico por um mecanismo dependente da mobilização interna de cálcio mediada pelo receptor de inositol 1,4,5-trifosfato $\left(I_{3} R 2\right)$ na maioria dos astrócitos do NTS em condição normoglicêmica;

6. A gliotransmissão por glutamato está presente no NTS em condição normoglicêmica, e pode ser regulada por alterações da concentração de glicose extracelular;

7. Uma condição hiperglicêmica altera a atividade basal de neurônios e astrócitos do NTS, e compromete a sensibilidade à baixa glicose extracelular e gliotransmissão;

8. A regulação da sensibilidade à baixa glicose extracelular em neurônios e astrócitos do NTS poderia estar relacionada à deficiência autonômica associada à hipoglicemia. 
REFERÊNCIAS BIBLIOGRÁFICAS 


\section{REFERÊNCIAS BIBLIOGRÁFICAS}

Accorsi-Mendonça D, Castania JA, Bonagamba LG, Machado BH \& Leão RM. (2011). Synaptic profile of nucleus tractus solitarius neurons involved with the peripheral chemoreflex pathways. Neuroscience 197, 107-120.

Accorsi-Mendonça D, Zoccal DB, Bonagamba LG \& Machado BH. (2013). Glial cells modulate the synaptic transmission of NTS neurons sending projections to ventral medulla of Wistar rats. Physiol Rep 1, e00080.

Agarwal A, Wu PH, Hughes EG, Fukaya M, Tischfield MA, Langseth AJ, Wirtz D \& Bergles DE. (2017). Transient Opening of the Mitochondrial Permeability Transition Pore Induces Microdomain Calcium Transients in Astrocyte Processes. Neuron 93, 587-605.e587.

Agrawal A, Pekkurnaz G \& Koslover EF. (2018). Spatial control of neuronal metabolism through glucose-mediated mitochondrial transport regulation. Elife 7.

Allen NJ \& Eroglu C. (2017). Cell Biology of Astrocyte-Synapse Interactions. Neuron 96, 697-708.

Anand BK, Chhina GS, Sharma KN, Dua S \& Singh B. (1964). ACTIVITY OF SINGLE NEURONS IN THE HYPOTHALAMIC FEEDING CENTERS: EFFECT OF GLUCOSE. Am J Physiol 207, 1146-1154.

Andrew SF, Dinh TT \& Ritter S. (2007). Localized glucoprivation of hindbrain sites elicits corticosterone and glucagon secretion. Am J Physiol Regul Integr Comp Physiol 292, R1792-1798.

Araque A, Carmignoto G, Haydon PG, Oliet SH, Robitaille R \& Volterra A. (2014). Gliotransmitters travel in time and space. Neuron 81, 728-739.

Arnold S. (2005). Estrogen suppresses the impact of glucose deprivation on astrocytic calcium levels and signaling independently of the nuclear estrogen receptor. Neurobiol Dis 20, 82-92.

Ashcroft FM \& Rorsman P. (2013). K(ATP) channels and islet hormone secretion: new insights and controversies. Nat Rev Endocrinol 9, 660-669.

Ashrafi G, Wu Z, Farrell RJ \& Ryan TA. (2017). GLUT4 Mobilization Supports Energetic Demands of Active Synapses. Neuron 93, 606-615.e603.

Bak LK \& Walls AB. (2018). CrossTalk opposing view: lack of evidence supporting an astrocyte-to-neuron lactate shuttle coupling neuronal activity to glucose utilisation in the brain. J Physiol.

Balfour RH, Hansen AM \& Trapp S. (2006). Neuronal responses to transient hypoglycaemia in the dorsal vagal complex of the rat brainstem. $J$ Physiol 570, 469-484. 
Balfour RH \& Trapp S. (2007). lonic currents underlying the response of rat dorsal vagal neurones to hypoglycaemia and chemical anoxia. J Physiol 579, 691702.

Barraco R, el-Ridi M, Ergene E, Parizon M \& Bradley D. (1992). An atlas of the rat subpostremal nucleus tractus solitarius. Brain Res Bull 29, 703-765.

Barros L. (2013). Metabolic signaling by lactate in the brain. Trends in Neurosciences 36, 396-404.

Baukrowitz T, Schulte U, Oliver D, Herlitze S, Krauter T, Tucker SJ, Ruppersberg JP \& Fakler B. (1998). PIP2 and PIP as determinants for ATP inhibition of KATP channels. Science 282, 1141-1144.

Belanger M, Allaman I \& Magistretti P. (2011). Brain Energy Metabolism: Focus on Astrocyte-Neuron Metabolic Cooperation. Cell Metabolism 14, 724-738.

Benarroch EE. (2014). Brain glucose transporters: implications for neurologic disease. Neurology 82, 1374-1379.

Bittner CX, Loaiza A, Ruminot I, Larenas V, Sotelo-Hitschfeld T, Gutiérrez R, Córdova A, Valdebenito R, Frommer WB \& Barros LF. (2010). High resolution measurement of the glycolytic rate. Front Neuroenergetics 2.

Blaustein MP, Juhaszova M, Golovina VA, Church PJ \& Stanley EF. (2002). Na/Ca exchanger and PMCA localization in neurons and astrocytes: functional implications. Ann N Y Acad Sci 976, 356-366.

Bohland M, Matveyenko AV, Saberi M, Khan AM, Watts AG \& Donovan CM. (2014). Activation of hindbrain neurons is mediated by portal-mesenteric vein glucosensors during slow-onset hypoglycemia. Diabetes 63, 2866-2875.

Boychuk CR, Gyarmati P, Xu H \& Smith BN. (2015). Glucose sensing by GABAergic neurons in the mouse nucleus tractus solitarii. J Neurophysiol 114, 999-1007.

Cahoy JD, Emery B, Kaushal A, Foo LC, Zamanian JL, Christopherson KS, Xing Y, Lubischer JL, Krieg PA, Krupenko SA, Thompson WJ \& Barres BA. (2008). A transcriptome database for astrocytes, neurons, and oligodendrocytes: a new resource for understanding brain development and function. $J$ Neurosci 28, 264-278.

Cheli VT, Santiago González DA, Smith J, Spreuer V, Murphy GG \& Paez PM. (2016). L-type voltage-operated calcium channels contribute to astrocyte activation In vitro. Glia 64, 1396-1415.

Cornell-Bell AH, Finkbeiner SM, Cooper MS \& Smith SJ. (1990). Glutamate induces calcium waves in cultured astrocytes: long-range glial signaling. Science 247, 470-473. 
Cryer PE. (2005). Mechanisms of hypoglycemia-associated autonomic failure and its component syndromes in diabetes. Diabetes 54, 3592-3601.

Cryer PE. (2006). Mechanisms of sympathoadrenal failure and hypoglycemia in diabetes. J Clin Invest 116, 1470-1473.

Cryer PE. (2007). Hypoglycemia, functional brain failure, and brain death. J Clin Invest 117, 868-870.

D'Agostino G, Lyons DJ, Cristiano C, Burke LK, Madara JC, Campbell JN, Garcia AP, Land BB, Lowell BB, Dileone RJ \& Heisler LK. (2016). Appetite controlled by a cholecystokinin nucleus of the solitary tract to hypothalamus neurocircuit. Elife 5.

Dallaporta M, Perrin J \& Orsini JC. (2000). Involvement of adenosine triphosphatesensitive $\mathrm{K}+$ channels in glucose-sensing in the rat solitary tract nucleus. Neurosci Lett 278, 77-80.

Daneman R \& Prat A. (2015). The blood-brain barrier. Cold Spring Harb Perspect Biol 7, a020412.

Di Castro MA, Chuquet J, Liaudet N, Bhaukaurally K, Santello M, Bouvier D, Tiret P \& Volterra A. (2011). Local Ca2+ detection and modulation of synaptic release by astrocytes. Nat Neurosci 14, 1276-1284.

Dienel GA. (2012). Brain lactate metabolism: the discoveries and the controversies. $J$ Cereb Blood Flow Metab 32, 1107-1138.

Dienel GA. (2017). Lack of appropriate stoichiometry: Strong evidence against an energetically important astrocyte-neuron lactate shuttle in brain. $J$ Neurosci Res 95, 2103-2125.

Donovan CM \& Watts AG. (2014). Peripheral and central glucose sensing in hypoglycemic detection. Physiology (Bethesda) 29, 314-324.

Durkee CA, Covelo A, Lines J, Kofuji P, Aguilar J \& Araque A. (2019). Gi/o proteincoupled receptors inhibit neurons but activate astrocytes and stimulate gliotransmission. Glia 67, 1076-1093.

Fellin T, Pascual O, Gobbo S, Pozzan T, Haydon PG \& Carmignoto G. (2004). Neuronal synchrony mediated by astrocytic glutamate through activation of extrasynaptic NMDA receptors. Neuron 43, 729-743.

Fernandez AM, Hernandez-Garzón E, Perez-Domper P, Perez-Alvarez A, Mederos S, Matsui T, Santi A, Trueba-Saiz A, García-Guerra L, Pose-Utrilla J, Fielitz J, Olson EN, Fernandez de la Rosa R, Garcia Garcia L, Pozo MA, Iglesias T, Araque A, Soya H, Perea G, Martin ED \& Torres Aleman I. (2017). Insulin Regulates Astrocytic Glucose Handling Through Cooperation With IGF-I. Diabetes 66, 64-74. 
Fiacco TA, Agulhon C, Taves SR, Petravicz J, Casper KB, Dong X, Chen J \& McCarthy KD. (2007). Selective stimulation of astrocyte calcium in situ does not affect neuronal excitatory synaptic activity. Neuron 54, 611-626.

Gao L, Ortega-Sáenz P, García-Fernández M, González-Rodríguez P, CaballeroEraso C \& López-Barneo J. (2014). Glucose sensing by carotid body glomus cells: potential implications in disease. Front Physiol 5, 398.

García-Cáceres C, Balland E, Prevot V, Luquet S, Woods SC, Koch M, Horvath TL, Yi CX, Chowen JA, Verkhratsky A, Araque A, Bechmann I \& Tschöp MH. (2019). Role of astrocytes, microglia, and tanycytes in brain control of systemic metabolism. Nat Neurosci 22, 7-14.

García-Cáceres C, Quarta C, Varela L, Gao Y, Gruber T, Legutko B, Jastroch M, Johansson P, Ninkovic J, Yi CX, Le Thuc O, Szigeti-Buck K, Cai W, Meyer CW, Pfluger PT, Fernandez AM, Luquet S, Woods SC, Torres-Alemán I, Kahn CR, Götz M, Horvath TL \& Tschöp MH. (2016). Astrocytic Insulin Signaling Couples Brain Glucose Uptake with Nutrient Availability. Cell 166, 867-880.

Garg V, Jiao J \& Hu K. (2009). Regulation of ATP-sensitive K+ channels by caveolinenriched microdomains in cardiac myocytes. Cardiovasc Res 82, 51-58.

Genc S, Kurnaz IA \& Ozilgen M. (2011). Astrocyte-neuron lactate shuttle may boost more ATP supply to the neuron under hypoxic conditions--in silico study supported by in vitro expression data. BMC Syst Biol 5, 162.

Gourine AV, Kasymov V, Marina N, Tang F, Figueiredo MF, Lane S, Teschemacher AG, Spyer KM, Deisseroth K \& Kasparov S. (2010). Astrocytes control breathing through pH-dependent release of ATP. Science 329, 571-575.

Gribble FM \& Reimann F. (2003). Sulphonylurea action revisited: the post-cloning era. Diabetologia 46, 875-891.

Grienberger C \& Konnerth A. (2012). Imaging calcium in neurons. Neuron 73, 862885.

Grill HJ \& Hayes MR. (2009). The nucleus tractus solitarius: a portal for visceral afferent signal processing, energy status assessment and integration of their combined effects on food intake. Int J Obes (Lond) 33 Suppl 1, S11-15.

Gross PM, Wall KM, Pang JJ, Shaver SW \& Wainman DS. (1990). Microvascular specializations promoting rapid interstitial solute dispersion in nucleus tractus solitarius. Am J Physiol 259, R1131-1138.

Guthrie PB, Knappenberger J, Segal M, Bennett MV, Charles AC \& Kater SB. (1999). ATP released from astrocytes mediates glial calcium waves. $J$ Neurosci 19, 520-528.

Halmos KC, Gyarmati P, Xu H, Maimaiti S, Jancsó G, Benedek G \& Smith BN. (2015). Molecular and functional changes in glucokinase expression in the 
brainstem dorsal vagal complex in a murine model of type 1 diabetes. Neuroscience 306, 115-122.

Hamilton N, Vayro S, Kirchhoff F, Verkhratsky A, Robbins J, Gorecki DC \& Butt AM. (2008). Mechanisms of ATP- and glutamate-mediated calcium signaling in white matter astrocytes. Glia 56, 734-749.

Harris JJ, Jolivet R \& Attwell D. (2012). Synaptic energy use and supply. Neuron 75, 762-777.

Haydon PG. (2016). The Evolving View of Astrocytes. Cerebrum 2016.

Haydon PG \& Carmignoto G. (2006). Astrocyte control of synaptic transmission and neurovascular coupling. Physiol Rev 86, 1009-1031.

Hermann GE, Viard E \& Rogers RC. (2014). Hindbrain glucoprivation effects on gastric vagal reflex circuits and gastric motility in the rat are suppressed by the astrocyte inhibitor fluorocitrate. J Neurosci 34, 10488-10496.

Herzog RI, Jiang L, Herman P, Zhao C, Sanganahalli BG, Mason GF, Hyder F, Rothman DL, Sherwin RS \& Behar KL. (2013). Lactate preserves neuronal metabolism and function following antecedent recurrent hypoglycemia. J Clin Invest 123, 1988-1998.

Hibino H, Inanobe A, Furutani K, Murakami S, Findlay I \& Kurachi Y. (2010). Inwardly rectifying potassium channels: their structure, function, and physiological roles. Physiol Rev 90, 291-366.

Himmi T, Dallaporta M \& Orsini JC. (2001). Effects of lactate on glucose-sensing neurons in the solitary tract nucleus. Physiology \& Behavior 74, 391-397.

Howarth C, Gleeson P \& Attwell D. (2012). Updated energy budgets for neural computation in the neocortex and cerebellum. J Cereb Blood Flow Metab 32, 1222-1232.

Jurányi Z, Sperlágh B \& Vizi ES. (1999). Involvement of P2 purinoceptors and the nitric oxide pathway in [3H]purine outflow evoked by short-term hypoxia and hypoglycemia in rat hippocampal slices. Brain Res 823, 183-190.

Kahlert S \& Reiser G. (2000). Requirement of glycolytic and mitochondrial energy supply for loading of $\mathrm{Ca}(2+)$ stores and InsP(3)-mediated $\mathrm{Ca}(2+)$ signaling in rat hippocampus astrocytes. J Neurosci Res 61, 409-420.

Karschin C, Ecke C, Ashcroft FM \& Karschin A. (1997). Overlapping distribution of K(ATP) channel-forming Kir6.2 subunit and the sulfonylurea receptor SUR1 in rodent brain. FEBS Lett 401, 59-64.

Kovács A \& Pál B. (2017). Astrocyte-Dependent Slow Inward Currents (SICs) Participate in Neuromodulatory Mechanisms in the Pedunculopontine Nucleus (PPN). Front Cell Neurosci 11, 16. 
Lam CK, Chari M, Su BB, Cheung GW, Kokorovic A, Yang CS, Wang PY, Lai TY \& Lam TK. (2010). Activation of N-methyl-D-aspartate (NMDA) receptors in the dorsal vagal complex lowers glucose production. J Biol Chem 285, 2191321921.

Lamy CM, Sanno H, Labouèbe G, Picard A, Magnan C, Chatton JY \& Thorens B. (2014). Hypoglycemia-activated GLUT2 neurons of the nucleus tractus solitarius stimulate vagal activity and glucagon secretion. Cell Metab 19, $527-$ 538.

Lee CY, Dallérac G, Ezan P, Anderova M \& Rouach N. (2016). Glucose Tightly Controls Morphological and Functional Properties of Astrocytes. Front Aging Neurosci 8, 82.

Lees GJ. (1991). Inhibition of sodium-potassium-ATPase: a potentially ubiquitous mechanism contributing to central nervous system neuropathology. Brain Res Brain Res Rev 16, 283-300.

Li W, Roy Choudhury G, Winters A, Prah J, Lin W, Liu R \& Yang SH. (2018). Hyperglycemia Alters Astrocyte Metabolism and Inhibits Astrocyte Proliferation. Aging Dis 9, 674-684.

Li X, Zima AV, Sheikh F, Blatter LA \& Chen J. (2005). Endothelin-1-induced arrhythmogenic $\mathrm{Ca2}+$ signaling is abolished in atrial myocytes of inositol-1,4,5trisphosphate(IP3)-receptor type 2-deficient mice. Circ Res 96, 1274-1281.

Litvin M, Clark AL \& Fisher SJ. (2013). Recurrent hypoglycemia: boosting the brain's metabolic flexibility. J Clin Invest 123, 1922-1924.

Liu HT, Sabirov RZ \& Okada Y. (2008). Oxygen-glucose deprivation induces ATP release via maxi-anion channels in astrocytes. Purinergic Signal 4, 147-154.

Lovatt D, Sonnewald U, Waagepetersen HS, Schousboe A, He W, Lin JH, Han X, Takano T, Wang S, Sim FJ, Goldman SA \& Nedergaard M. (2007). The transcriptome and metabolic gene signature of protoplasmic astrocytes in the adult murine cortex. J Neurosci 27, 12255-12266.

Magistretti PJ \& Allaman I. (2015). A cellular perspective on brain energy metabolism and functional imaging. Neuron 86, 883-901.

Marina N, Turovsky E, Christie IN, Hosford PS, Hadjihambi A, Korsak A, Ang R, Mastitskaya S, Sheikhbahaei S, Theparambil SM \& Gourine AV. (2017). Brain metabolic sensing and metabolic signaling at the level of an astrocyte. Glia.

Martin-Fernandez M, Jamison S, Robin LM, Zhao Z, Martin ED, Aguilar J, Benneyworth MA, Marsicano G \& Araque A. (2017). Synapse-specific astrocyte gating of amygdala-related behavior. Nat Neurosci 20, 1540-1548. 
Marty N, Dallaporta M, Foretz M, Emery M, Tarussio D, Bady I, Binnert C, Beermann F \& Thorens B. (2005). Regulation of glucagon secretion by glucose transporter type 2 (glut2) and astrocyte-dependent glucose sensors. J Clin Invest 115, 3545-3553.

Marty N, Dallaporta M \& Thorens B. (2007). Brain glucose sensing, counterregulation, and energy homeostasis. Physiology (Bethesda) 22, 241-251.

Martín R, Bajo-Grañeras R, Moratalla R, Perea G \& Araque A. (2015). Circuit-specific signaling in astrocyte-neuron networks in basal ganglia pathways. Science 349, 730-734.

Mathiisen TM, Lehre KP, Danbolt NC \& Ottersen OP. (2010). The perivascular astroglial sheath provides a complete covering of the brain microvessels: an electron microscopic 3D reconstruction. Glia 58, 1094-1103.

Mayer J. (1953). Glucostatic mechanism of regulation of food intake. N Engl J Med 249, 13-16.

McDougal DH, Hermann GE \& Rogers RC. (2011). Vagal afferent stimulation activates astrocytes in the nucleus of the solitary tract via AMPA receptors: evidence of an atypical neural-glial interaction in the brainstem. J Neurosci 31, $14037-14045$.

McDougal DH, Hermann GE \& Rogers RC. (2013). Astrocytes in the nucleus of the solitary tract are activated by low glucose or glucoprivation: evidence for glial involvement in glucose homeostasis. Front Neurosci 7, 249.

McNay EC \& Cotero VE. (2010). Mini-review: impact of recurrent hypoglycemia on cognitive and brain function. Physiol Behav 100, 234-238.

McNay EC, McCarty RC \& Gold PE. (2001). Fluctuations in brain glucose concentration during behavioral testing: dissociations between brain areas and between brain and blood. Neurobiol Learn Mem 75, 325-337.

McTaggart JS, Clark RH \& Ashcroft FM. (2010). The role of the KATP channel in glucose homeostasis in health and disease: more than meets the islet. $J$ Physiol 588, 3201-3209.

Mergenthaler P, Lindauer U, Dienel GA \& Meisel A. (2013). Sugar for the brain: the role of glucose in physiological and pathological brain function. Trends Neurosci 36, 587-597.

Mimee A \& Ferguson AV. (2015). Glycemic state regulates melanocortin, but not nesfatin-1, responsiveness of glucose-sensing neurons in the nucleus of the solitary tract. Am J Physiol Regul Integr Comp Physiol 308, R690-699.

Müller M, Brockhaus J \& Ballanyi K. (2002). ATP-independent anoxic activation of ATP-sensitive $\mathrm{K}+$ channels in dorsal vagal neurons of juvenile mice in situ. Neuroscience 109, 313-328. 
Navarrete M \& Araque A. (2008). Endocannabinoids mediate neuron-astrocyte communication. Neuron 57, 883-893.

Navarrete M, Perea G, Fernandez de Sevilla D, Gómez-Gonzalo M, Núñez A, Martín ED \& Araque A. (2012). Astrocytes mediate in vivo cholinergic-induced synaptic plasticity. PLoS Biol 10, e1001259.

Navarrete M, Perea G, Maglio L, Pastor J, García de Sola R \& Araque A. (2013). Astrocyte calcium signal and gliotransmission in human brain tissue. Cereb Cortex 23, 1240-1246.

Nichols CG. (2006). KATP channels as molecular sensors of cellular metabolism. Nature 440, 470-476.

Nortley R \& Attwell D. (2017). Control of brain energy supply by astrocytes. Curr Opin Neurobiol 47, 80-85.

Obel LF, Müller MS, Walls AB, Sickmann HM, Bak LK, Waagepetersen HS \& Schousboe A. (2012). Brain glycogen-new perspectives on its metabolic function and regulation at the subcellular level. Front Neuroenergetics 4, 3.

Oliveira JF, Sardinha VM, Guerra-Gomes S, Araque A \& Sousa N. (2015). Do stars govern our actions? Astrocyte involvement in rodent behavior. Trends Neurosci 38, 535-549.

Oomura Y, Ooyama H, Sugimori M, Nakamura T \& Yamada Y. (1974). Glucose inhibition of the glucose-sensitive neurone in the rat lateral hypothalamus. Nature 247, 284-286.

Oz G, Kumar A, Rao JP, Kodl CT, Chow L, Eberly LE \& Seaquist ER. (2009). Human brain glycogen metabolism during and after hypoglycemia. Diabetes 58, 19781985.

Patching SG. (2017). Glucose Transporters at the Blood-Brain Barrier: Function, Regulation and Gateways for Drug Delivery. Mol Neurobiol 54, 1046-1077.

Paukert M, Agarwal A, Cha J, Doze VA, Kang JU \& Bergles DE. (2014). Norepinephrine controls astroglial responsiveness to local circuit activity. Neuron 82, 1263-1270.

Pearson-Leary J \& McNay EC. (2016). Novel Roles for the Insulin-Regulated Glucose Transporter-4 in Hippocampally Dependent Memory. J Neurosci 36, 11851-11864.

Pellerin L \& Magistretti PJ. (2012). Sweet sixteen for ANLS. J Cereb Blood Flow Metab 32, 1152-1166.

Perea G, Gómez R, Mederos S, Covelo A, Ballesteros JJ, Schlosser L, HernándezVivanco A, Martín-Fernández M, Quintana R, Rayan A, Díez A, Fuenzalida M, 
Agarwal A, Bergles DE, Bettler B, Manahan-Vaughan D, Martín ED, Kirchhoff F \& Araque A. (2016). Activity-dependent switch of GABAergic inhibition into glutamatergic excitation in astrocyte-neuron networks. Elife 5.

Petravicz J, Boyt KM \& McCarthy KD. (2014). Astrocyte IP3R2-dependent Ca(2+) signaling is not a major modulator of neuronal pathways governing behavior. Front Behav Neurosci 8, 384.

Petravicz J, Fiacco TA \& McCarthy KD. (2008). Loss of IP3 receptor-dependent Ca2+ increases in hippocampal astrocytes does not affect baseline CA1 pyramidal neuron synaptic activity. J Neurosci 28, 4967-4973.

Poskanzer KE \& Yuste R. (2016). Astrocytes regulate cortical state switching in vivo. Proc Natl Acad Sci U S A 113, E2675-2684.

Proks P, Reimann F, Green N, Gribble F \& Ashcroft F. (2002). Sulfonylurea stimulation of insulin secretion. Diabetes 51 Suppl 3, S368-376.

Pérez-Alvarez A, Araque A \& Martín ED. (2013). Confocal microscopy for astrocyte in vivo imaging: Recycle and reuse in microscopy. Front Cell Neurosci 7, 51.

Raichle ME \& Gusnard DA. (2002). Appraising the brain's energy budget. Proc Natl Acad Sci U S A 99, 10237-10239.

Reeves AM, Shigetomi E \& Khakh BS. (2011). Bulk loading of calcium indicator dyes to study astrocyte physiology: key limitations and improvements using morphological maps. J Neurosci 31, 9353-9358.

Reiner DJ, Mietlicki-Baase EG, McGrath LE, Zimmer DJ, Bence KK, Sousa GL, Konanur VR, Krawczyk J, Burk DH, Kanoski SE, Hermann GE, Rogers RC \& Hayes MR. (2016). Astrocytes Regulate GLP-1 Receptor-Mediated Effects on Energy Balance. J Neurosci 36, 3531-3540.

Ritter S, Dinh TT \& Zhang Y. (2000). Localization of hindbrain glucoreceptive sites controlling food intake and blood glucose. Brain Res 856, 37-47.

Roberts BL, Zhu M, Zhao H, Dillon C \& Appleyard SM. (2017). High glucose increases action potential firing of catecholamine neurons in the nucleus of the solitary tract by increasing spontaneous glutamate inputs. Am J Physiol Regul Integr Comp Physiol 313, R229-R239.

Rogers RC, McDougal DH, Ritter S, Qualls-Creekmore E \& Hermann GE. (2018). Response of catecholaminergic neurons in the mouse hindbrain to glucoprivic stimuli is astrocyte dependent. Am J Physiol Regul Integr Comp Physiol 315, R153-R164.

Rooijackers HM, Wiegers EC, Tack CJ, van der Graaf M \& de Galan BE. (2016). Brain glucose metabolism during hypoglycemia in type 1 diabetes: insights from functional and metabolic neuroimaging studies. Cell Mol Life Sci 73, 705722. 
Rosenthal JM, Amiel SA, Yágüez L, Bullmore E, Hopkins D, Evans M, Pernet A, Reid H, Giampietro V, Andrew CM, Suckling J, Simmons A \& Williams SC. (2001). The effect of acute hypoglycemia on brain function and activation: a functional magnetic resonance imaging study. Diabetes 50, 1618-1626.

Routh VH, Hao L, Santiago AM, Sheng Z \& Zhou C. (2014). Hypothalamic glucose sensing: making ends meet. Front Syst Neurosci 8, 236.

Rusakov DA. (2015). Disentangling calcium-driven astrocyte physiology. Nat Rev Neurosci 16, 226-233.

Rusakov DA, Zheng K \& Henneberger C. (2011). Astrocytes as regulators of synaptic function: a quest for the Ca2+ master key. Neuroscientist 17, 513-523.

Seaquist ER, Damberg GS, Tkac I \& Gruetter R. (2001). The effect of insulin on in vivo cerebral glucose concentrations and rates of glucose transport/metabolism in humans. Diabetes 50, 2203-2209.

Sharma G \& Vijayaraghavan S. (2001). Nicotinic cholinergic signaling in hippocampal astrocytes involves calcium-induced calcium release from intracellular stores. Proc Natl Acad Sci U S A 98, 4148-4153.

Shigetomi E, Bushong EA, Haustein MD, Tong X, Jackson-Weaver O, Kracun S, Xu J, Sofroniew MV, Ellisman MH \& Khakh BS. (2013). Imaging calcium microdomains within entire astrocyte territories and endfeet with GCaMPs expressed using adeno-associated viruses. J Gen Physiol 141, 633-647.

Shigetomi E, Kracun S \& Khakh BS. (2010a). Monitoring astrocyte calcium microdomains with improved membrane targeted GCaMP reporters. Neuron Glia Biol 6, 183-191.

Shigetomi E, Kracun S, Sofroniew MV \& Khakh BS. (2010b). A genetically targeted optical sensor to monitor calcium signals in astrocyte processes. Nat Neurosci 13, 759-766.

Shigetomi E, Patel S \& Khakh BS. (2016). Probing the Complexities of Astrocyte Calcium Signaling. Trends Cell Biol 26, 300-312.

Shigetomi E, Tong X, Kwan KY, Corey DP \& Khakh BS. (2011). TRPA1 channels regulate astrocyte resting calcium and inhibitory synapse efficacy through GAT-3. Nat Neurosci 15, 70-80.

Shyng S, Ferrigni T \& Nichols CG. (1997). Regulation of KATP channel activity by diazoxide and MgADP. Distinct functions of the two nucleotide binding folds of the sulfonylurea receptor. J Gen Physiol 110, 643-654.

Shyng SL, Barbieri A, Gumusboga A, Cukras C, Pike L, Davis JN, Stahl PD \& Nichols CG. (2000). Modulation of nucleotide sensitivity of ATP-sensitive 
potassium channels by phosphatidylinositol-4-phosphate 5-kinase. Proc Natl Acad Sci U S A 97, 937-941.

Song M \& Yu SP. (2014). Ionic regulation of cell volume changes and cell death after ischemic stroke. Transl Stroke Res 5, 17-27.

Song Z, Levin BE, McArdle JJ, Bakhos N \& Routh VH. (2001). Convergence of preand postsynaptic influences on glucosensing neurons in the ventromedial hypothalamic nucleus. Diabetes 50, 2673-2681.

Song Z \& Routh VH. (2006). Recurrent hypoglycemia reduces the glucose sensitivity of glucose-inhibited neurons in the ventromedial hypothalamus nucleus. $A m \mathrm{~J}$ Physiol Regul Integr Comp Physiol 291, R1283-1287.

Steinbusch L, Labouèbe G \& Thorens B. (2015). Brain glucose sensing in homeostatic and hedonic regulation. Trends Endocrinol Metab 26, 455-466.

Stobart JL \& Anderson CM. (2013). Multifunctional role of astrocytes as gatekeepers of neuronal energy supply. Front Cell Neurosci 7, 38.

Suh SW, Bergher JP, Anderson CM, Treadway JL, Fosgerau K \& Swanson RA. (2007). Astrocyte glycogen sustains neuronal activity during hypoglycemia: studies with the glycogen phosphorylase inhibitor CP-316,819 ([R-R* $\left.\mathrm{R}^{*}\right]-5-$ chloro-N-[2-hydroxy-3-(methoxymethylamino)-3-oxo-1-(phenylmethyl)propyl]1H-indole-2-carboxamide). J Pharmacol Exp Ther 321, 45-50.

Thorens B. (2012). Sensing of glucose in the brain. Handb Exp Pharmacol, 277-294.

Thorens B. (2015). GLUT2, glucose sensing and glucose homeostasis. Diabetologia 58, 221-232.

Vaarmann A, Gandhi S \& Abramov AY. (2010). Dopamine induces Ca2+ signaling in astrocytes through reactive oxygen species generated by monoamine oxidase. J Biol Chem 285, 25018-25023.

Verberne AJ, Sabetghadam A \& Korim WS. (2014). Neural pathways that control the glucose counterregulatory response. Front Neurosci 8, 38.

Wyss MT, Jolivet R, Buck A, Magistretti PJ \& Weber B. (2011). In vivo evidence for lactate as a neuronal energy source. J Neurosci 31, 7477-7485.

Yang J, Yang H, Liu Y, Li X, Qin L, Lou H, Duan S \& Wang H. (2016). Astrocytes contribute to synapse elimination via type 2 inositol 1,4,5-trisphosphate receptor-dependent release of ATP. Elife 5, e15043.

Zecchin A, Stapor PC, Goveia J \& Carmeliet P. (2015). Metabolic pathway compartmentalization: an underappreciated opportunity? Curr Opin Biotechnol $34,73-81$. 
Zhao S, Kanoski SE, Yan J, Grill HJ \& Hayes MR. (2012). Hindbrain leptin and glucagon-like-peptide-1 receptor signaling interact to suppress food intake in an additive manner. Int $J$ Obes (Lond) 36, 1522-1528.

Zoccal DB, Furuya WI, Bassi M, Colombari DS \& Colombari E. (2014). The nucleus of the solitary tract and the coordination of respiratory and sympathetic activities. Front Physiol 5, 238. 
ANEXOS 


\section{ANEXO A}

Artigo publicado relacionado à tese 


\title{
A voltage-dependent depolarization induced by low external glucose in neurons of the nucleus of the tractus solitarius: interaction with $\mathrm{K}_{\text {ATP }}$ channels
}

\author{
Cahuê De Bernardis Murat and Ricardo Mauricio Leão (iD) \\ Department of Physiology, School of Medicine of Ribeirão Preto, University of São Paulo, Ribeirão Preto, SP, Brazil
}

Edited by: Ian Forsythe \& Yasuhiko Minokoshi

\begin{abstract}
Key points
- Neurons from the brainstem nucleus of the tractus solitarius (NTS) participate in the counter-regulatory mechanisms in response to hypoglycaemia.

- ATP-sensitive potassium $\left(\mathrm{K}_{\mathrm{ATP}}\right)$ channels are expressed in NTS neurons, and are partially open at rest in normoglycaemic $5 \mathrm{mM}$ glucose.

- In normoglycaemic conditions, most NTS neurons depolarize in response to low external glucose $(0.5 \mathrm{mM})$, via a voltage-dependent mechanism.

- Conversely, most NTS neurons incubated in hyperglycaemic $10 \mathrm{mM}$ glucose do not respond to low glucose due to a more positive resting membrane potential caused by the closure of $\mathrm{K}_{\mathrm{ATP}}$ channels following increased intracellular metabolic ATP.

- Our findings show that in hyperglycaemic conditions, NTS neurons failed to sense rapid changes in external glucose, which could be related to hypoglycaemia-associated autonomic failure.
\end{abstract}

\begin{abstract}
The nucleus of the tractus solitarius (NTS) is an integrative centre for autonomic counter-regulatory responses to hypoglycaemia. $\mathrm{K}_{\mathrm{ATP}}$ channels link the metabolic status of the neuron to its excitability. Here we investigated the influence of $\mathrm{K}_{\mathrm{ATP}}$ channels on the membrane potential of NTS neurons in normo- and hyperglycaemic external glucose concentrations, and after switching to a hypoglycaemic concentration, using in vitro electrophysiological recordings in brainstem slices. We found that in normoglycaemic $(5 \mathrm{mM})$ glucose, tolbutamide, a $\mathrm{K}_{\mathrm{ATP}}$ channel antagonist, depolarized the membrane of most neurons, and this effect was observed in more hyperpolarized neurons. All neurons hyperpolarized after pharmacological activation of $\mathrm{K}_{\mathrm{ATP}}$ channels. Most NTS neurons depolarized in the presence of low glucose $(0.5 \mathrm{mM})$, and this effect was only seen in hyperpolarized neurons. The effect of glucose was caused by a cationic current with a reversal potential around $-50 \mathrm{mV}$. In the presence of hyperglycaemic glucose
\end{abstract}

\footnotetext{
Cahuê Murat holds a BSc in Biological Sciences and an MSc in Molecular Biology, and currently is a fourth-year PhD candidate in physiology at the University of São Paulo, Brazil. Together with Professor Ricardo Leão, he has been studying the electrophysiological mechanisms induced by low external glucose in the neurons of the brainstem nucleus of the tractus solitarius. In his upcoming projects, Cahue aims to investigate how astrocytes monitor signals related to energy status, and their role in synaptic transmission and information processing involved in brain control of metabolism.
}

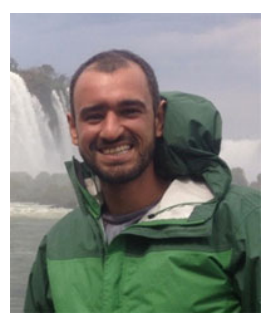

This article was first published as a preprint. de Bernardis Murat C, Leao R. (2019). A voltage-dependent depolarization induced by low external glucose in neurons of the nucleus of the tractus solitarius of rats: interaction with $\mathrm{K}_{\mathrm{ATP}}$ channels regulated by external glucose. bioRxiv. https://doi.org/10.1101/328658. 
(10 $\mathrm{mM}$ ), neurons were more depolarized, and fewer neurons responded to $\mathrm{K}_{\mathrm{ATP}}$ blockage. Application of $0.5 \mathrm{mM}$ glucose solution to these neurons depolarized the membrane only in more hyperpolarized neurons. We conclude that NTS neurons present with $\mathrm{K}_{\mathrm{ATP}}$ channels open at rest in normoglycaemic conditions, and their membrane potential is affected by extracellular glucose. Moreover, NTS neurons depolarize the membrane in response to the application of a low glucose solution, but this effect is occluded by membrane depolarization triggered by $\mathrm{K}_{\mathrm{ATP}}$ blockage. Our data suggest a homeostatic regulation of the membrane potential by external glucose, and a possible mechanism related to the hypoglycaemia-associated autonomic failure.

(Received 22 January 2019; accepted after revision 21 March 2019; first published online 30 March 2019)

Corresponding author R. M. Leão: Departamento de Fisiologia, FMRP-USP, Av. Bandeirantes 3900, Ribeirão Preto SP. 14049-900, Brazil. Email: leaor@fmrp.usp.br

\section{Introduction}

The brainstem nucleus of the tractus solitarius (NTS) is the primary central site for viscerosensory afferent fibres arising from peripheral neurons, including peripheral chemo-sensing neurons (Accorsi-Mendonça et al. 2011; Donovan \& Watts, 2014). NTS neurons densely project to the dorsal motor nucleus of the vagus (DMX), where the cell bodies of the preganglionic parasympathetic branch of the vagus are located (Marty et al. 2007; Verberne et al. 2014). Local nutrient and metabolic signals (including glucose and metabolites), as well as direct modulation by receptor agonists/antagonists in NTS neurons, induce physiological responses necessary for the regulation of blood glucose concentration (Ritter et al. 2000; Lam et al. 2010; Zhao et al. 2012). The NTS is associated with the physiological responses to hypoglycaemia, the counter-regulatory responses, which result in glucagon secretion, increased food intake behaviour, and increased sympathetic tone. For instance, hypoglycaemia induces c-Fos immunoreactivity in NTS neurons, and portal-mesenteric deafferentation suppressed this effect (Bohland et al. 2014). Inhibitors of glucose metabolism injected in the NTS increased glucagon secretion and food intake (Ritter et al. 2000; Andrew et al. 2007). Additionally, low glucose increases firing activity in carotid sinus nerve (Gao et al. 2014), which mostly propagates signals into the NTS. Therefore, NTS neurons integrate a variety of synaptic inputs and mediate a plethora of autonomic counter-regulatory mechanisms in response to food ingestion and signals related to the glycaemic state in order to ensure adequate levels of glucose, including feeding behaviour, gastric motility and hormonal secretion (Marty et al. 2007; Donovan \& Watts, 2014; Hermann et al. 2014).

The NTS is an interesting region for detecting changes in extracellular glucose due to the presence of fenestrated capillaries (Gross et al. 1990) and its proximity to the area postrema, a circumventricular organ. Several reports have shown that NTS neurons directly detect fluctuations in glucose levels in the extracellular milieu. For instance,
(Mimee \& Ferguson 2015) showed that slightly more than half of NTS neurons could depolarize or hyperpolarize their resting membrane potential (RMP) in response to both an increase and a decrease in external glucose in vitro. On the other hand, Balfour et al. (2006) observed that only a minority of the NTS neurons changed membrane potential in response to a zero glucose solution. Lamy et al. (2014) showed a depolarization of the membrane potential in response to $0.5 \mathrm{mM}$ external glucose, only in GLUT-2/GABAergic neurons in the NTS. Finally, McDougal et al. (2013) showed that a fraction of glia and neurons of NTS increased intracellular calcium in response to low glucose and inhibitors of glycolysis.

The ATP-sensitive potassium $\left(\mathrm{K}_{\mathrm{ATP}}\right)$ channel links metabolic status and electrical excitability (Nichols, 2006), as classically described in pancreatic beta-cells (Ashcroft \& Rorsman, 2013). This channel is a hetero-octameric complex comprising four pore-forming $\mathrm{K}_{\mathrm{ir}} 6$.x subunits and four regulatory sulfonylurea receptor (SURx) subunits, and it conducts an inwardly rectifying potassium current that is inhibited by ATP binding to $\mathrm{K}_{\mathrm{ir}} 6 . \mathrm{x}$ subunits and stimulated by ADP interaction with nucleotide-binding sites within SURx subunits (Hibino et al. 2010). In the NTS, the subunits $\mathrm{K}_{\mathrm{ir}} 6.2$ and SUR1 are expressed in glucose-sensing neurons (Balfour et al. 2006; Halmos et al. 2015). Glucose-excited NTS neurons indeed appear to respond to changes in glucose levels using a mechanism similar to pancreatic beta-cells, in a GLUT/glucokinase/ $\mathrm{K}_{\mathrm{ATP}}$-dependent system (Thorens, 2012; Ashcroft \& Rorsman, 2013), and $K_{\text {ATP }}$ channel antagonists blunt the responsive of these neurons to increased glucose levels (Balfour et al. 2006; Boychuk et al. 2015).

Here we aimed to investigate how the membrane potential of NTS neurons is affected by decreasing glucose concentrations, and the role of $\mathrm{K}_{\text {ATP }}$ channels. We found that NTS neurons depolarize in response to low external glucose only when their membrane potential is hyperpolarized below $-60 \mathrm{mV}$. Incubation in high glucose external solution depolarizes the neurons by blocking $\mathrm{K}_{\mathrm{ATP}}$ channels, and blunts their response to low glucose. 
This unexpected finding shows that NTS neurons in the presence of hyperglycaemic glucose concentrations, do not respond to fast reductions in external glucose, with implications for situations of prolonged hyperglycaemia, as in diabetes mellitus.

\section{Methods}

\section{Brainstem slices preparation}

Animal procedures were performed according to the protocol approved by the Committee on Ethics in Animal Experimentation (CEUA) from the School of Medicine of Ribeirão Preto, University of São Paulo (protocol no. 149/2015). Brainstem slices containing the subpostremal NTS were obtained as previously described (Accorsi-Mendonça et al. 2011). Male Wistar rats (3 to 11 weeks old) were decapitated following isoflurane anaesthesia, and the brainstem was quickly removed and placed in a dish containing ice-cold artificial cerebrospinal fluid (aCSF) modified for slicing, containing (in mM): 87 $\mathrm{NaCl}, 2.5 \mathrm{KCl}, 1.25 \mathrm{NaH}_{2} \mathrm{PO}_{4}, 25 \mathrm{NaHCO}_{3}, 75$ sucrose, $25 \mathrm{D}$-glucose, $0.2 \mathrm{CaCl}_{2}$, and $7 \mathrm{MgCl}_{2}(330 \mathrm{mOsm} / \mathrm{kg}$ $\mathrm{H}_{2} \mathrm{O}, \mathrm{pH} 7.4$ when bubbled with a carbogenic mixture of $95 \% \mathrm{O}_{2}$ and $5 \% \mathrm{CO}_{2}$ ). The specimen was glued to the sectioning stage, and submerged in ice-cold slicing aCSF in a vibratome (Vibratome 1000 Plus, Vibratome) chamber. Then, three to four coronal brainstem slices $(250 \mu \mathrm{M})$ containing the NTS near the level of the area postrema (i.e., $\pm 500 \mu \mathrm{M}$ rostral and caudal) were sectioned and incubated at $32-33^{\circ} \mathrm{C}$ for $45 \mathrm{~min}$ in aCSF, containing (in $\mathrm{mM}$ ): $125 \mathrm{NaCl}, 2.5 \mathrm{KCl}, 1.25 \mathrm{NaH}_{2} \mathrm{PO}_{4}, 25 \mathrm{NaHCO}_{3}, 5$ D-glucose, $2 \mathrm{CaCl}_{2}$, and $1 \mathrm{MgCl}_{2}\left(298 \mathrm{mOsm} / \mathrm{kg} \mathrm{H}_{2} \mathrm{O}, \mathrm{pH}\right.$ 7.35 when bubbled with a carbogenic mixture of $95 \% \mathrm{O}_{2}$ and $5 \% \mathrm{CO}_{2}$ ). In some experiments, the aCSF contained $10 \mathrm{mM}$ glucose. After this period, the slices were stored in the same solution at room temperature until electrophysiological recording. Low glucose $(0.5 \mathrm{mM}) \mathrm{aCSF}$, as well as $10 \mathrm{mM}$ glucose aCSF, were made using equimolar amounts of $\mathrm{NaCl}$ or sucrose to maintain osmolality equal to the $5 \mathrm{mM}$ glucose aCSF. No differences were observed in both conditions. The use of $5 \mathrm{mM}$ glucose as the basal level, a concentration lower than used previously by our group (see Accorsi-Mendonça et al. 2011 for instance), and other groups (see Balfour et al. 2006, for instance), is because $5 \mathrm{mM}(90 \mathrm{mg} / \mathrm{dL})$ is close to a regular glycaemic situation. We found that the neurons survived well in this extracellular concentration of glucose and were viable for recording.

\section{Electrophysiological recordings}

Single brainstem slices were transferred to a chamber mounted on a stage of an upright microscope (BX51WI;
Olympus, Japan), and continuously perfused with aCSF at $30-33^{\circ} \mathrm{C}$ using an inline heating system (TC-324B; Warner Instruments, Hamden, CT, USA) at a rate of $\sim 2 \mathrm{~mL} / \mathrm{min}$ using a gravity-driven perfusion system. Neurons were then visualized under DIC optics with a $60 \times$ immersion objective, and patched with electrodes made with thick-walled borosilicate glass (BF150-86-10; Sutter Instruments, Novato, CA, USA) pulled using a horizontal puller (P-87; Sutter Instruments). The electrodes were filled with an internal solution, containing (in $\mathrm{mM}$ ): 128 potassium gluconate, $8 \mathrm{KCl}, 10 \mathrm{HEPES}, 0.5 \mathrm{EGTA}, 4$ $\mathrm{Mg}_{2} \mathrm{ATP}, 0.3 \mathrm{Na}_{2} \mathrm{GTP}$, and 10 sodium phosphocreatine (295 mOsm $/ \mathrm{kg} \mathrm{H}_{2} \mathrm{O}, \mathrm{pH}$ 7.3), resulting in pipette tip resistance between 3 and $7 \mathrm{M} \Omega$.

Whole-cell patch-clamp recordings were performed with an EPC-10 patch-clamp amplifier (HEKA Elektronik, Lambrecht, Germany) using the PatchMaster acquisition software (HEKA Elektronik), in voltage- and current-clamp mode. Data were acquired at $20 \mathrm{kHz}$ and low-pass filtered at $5 \mathrm{kHz}$ (Bessel). Cells with series resistance larger than $30 \mathrm{M} \Omega$ or showing large variations during whole-cell recording were discarded. After entering the whole-cell configuration, neurons were allowed to stabilize their membrane potential for $\sim 10 \mathrm{~min}$, and during this period depolarizing currents were injected to elicit action potential firing to confirm the neuronal identity of the recorded cell. When tetrodotoxin was used, it was applied only after confirmation that the recorded cell was a neuron. Membrane potential was monitored for $10 \mathrm{~min}$ in aCSF with 5 or $10 \mathrm{mM}$ glucose before switching to low glucose $(0.5 \mathrm{mM})$ or drug-containing solutions for $10 \mathrm{~min}$ before returning to 5 or $10 \mathrm{mM}$ glucose aCSF. In some experiments, we perfused the low glucose solution for more prolonged periods (20-30 min). Hyperpolarizing pulses (ranging from -30 to $-60 \mathrm{pA} ; 1000 \mathrm{~ms}$ ) were applied every $15 \mathrm{~s}$ to monitor input resistance. All conditions were recorded for $10 \mathrm{~min}$, and we only recorded one neuron per slice. Based both on previous reports regarding glucose sensing in NTS neurons (Balfour et al. 2006; Lamy et al. 2014; Boychuk et al. 2015) and the response profile to a low glucose challenge observed in the current investigation, we assumed that a neuron was responsive to low glucose and/or drug when they showed a clear membrane potential alteration induced by one of these conditions. We observed that most neurons that presented this behaviour had robust membrane potential changes. Neurons with membrane potential oscillations smaller than $\pm 3 \mathrm{mV}$ did not have a clear distinction from the baseline oscillations. Thus, we considered low glucose and/or drug responsive neurons to be those that presented membrane potential changes bigger than $\pm 3 \mathrm{mV}$.

For voltage-clamp experiments, neurons were clamped at $-70 \mathrm{mV}$ and the membrane potential varied from $-125 \mathrm{mV}$ to $-65 \mathrm{mV}$ in seven steps of $500 \mathrm{~ms}$. Series resistance was compensated by $60 \%$. 


\section{Drugs}

Tetrodotoxin $(0.5 \mu \mathrm{M})$ was purchased from Alomone Labs (Jerusalem, Israel), and tolbutamide $(100 \mu \mathrm{M})$ and diazoxide $(200 \mu \mathrm{M})$ were purchased from Sigma (St Louis, MO, USA). All drugs were diluted at the time of the experiment from $1000 \times$ concentrated stock solutions in DMSO or water. DMSO in the final concentration of $0.001 \%$ did not affect the membrane potential (not shown).

\section{Data analysis}

Electrophysiological data were analysed with custom routines written in IGOR Pro 6.37 (WaveMetrics, Portland, OR, USA). Voltages were corrected for a measured liquid junction potential of $10 \mathrm{mV}$. Data are shown as means \pm SEM. All data values were determined after obtained a plateau response. Resting membrane potential was analysed as the mean of an all points histogram of the recording taken in a segment of the last 3-4 min. Membrane conductances and reversal potentials were calculated by linear regressions of the current-voltage plots.

Statistical analyses were performed using GraphPad Prism 8.0 (GraphPad Software, La Jolla, CA, USA), using Student's paired and unpaired two-tailed $t$ tests, and one-way ordinary or repeated measures ANOVA with Fisher's LSD test. Correlations were determined using a linear regression. Percentages were compared with Fisher's exact test. The significance level was set at $P<0.05$.

\section{Results}

NTS neurons incubated in $5 \mathrm{mM}$ glucose express partially closed $\mathrm{K}_{\text {ATP }}$ channels

$\mathrm{K}_{\mathrm{ATP}}$ channels are traditionally associated with coupling the cell energy status and electrical activity, triggering depolarization in a high ATP/ADP ratio, and hyperpolarization in a low ATP/ADP ratio (Nichols, 2006; Hibino et al. 2010). NTS neurons express $K_{\text {ATP }}$ channels, which are more responsive to metabolic ATP than to ATP provided by the whole-cell pipette solution, even in intracellular ATP concentrations of 3-4 mM, as used in our recordings (Balfour et al. 2006). In order to know whether $\mathrm{K}_{\text {ATP }}$ channels in the NTS neurons were active in neurons incubated in $5 \mathrm{mM}$ external glucose, a near-normoglycaemic concentration, we applied their antagonist tolbutamide (100 $\mu \mathrm{M} ; n=15$, seven animals) and measured the change in RMP. We found that the neurons were viable in aCSF with $5 \mathrm{mM}$ glucose during the whole incubation period of the experiment (up to $5 \mathrm{~h}$ ).
We verified that in 10 neurons (67\%) incubated with aCSF containing $5 \mathrm{mM}$ glucose and tetrodotoxin (TTX), tolbutamide triggered a strong and fast depolarization $(16.7 \pm 2.7 \mathrm{mV}$, from a mean of $-76.1 \pm 2.6 \mathrm{mV}$ to $-59.4 \pm 1.2 \mathrm{mV} ; P=0.0002$; Fig. $1 A a$ and $b$ ), accompanied by robust increased in membrane input resistance $\left(R_{\text {input }} ; 190.5 \pm 55.2 \mathrm{M} \Omega\right.$, from a mean of $406.9 \pm 79.2 \mathrm{M} \Omega$ to $597.4 \pm 73.4 \mathrm{M} \Omega ; P=0.007$; Fig. $1 A c)$, in accordance with its effect in blocking $\mathrm{K}_{\mathrm{ATP}}$ channels. Additionally, five neurons (33\%) did not change their RMP in response to tolbutamide $(1.0 \pm 0.5 \mathrm{mV}$, from a mean of $-65.1 \pm 2.4 \mathrm{mV}$ to $-64.1 \pm 2.2 \mathrm{mV} ; P=0.1$; Fig. $1 B a$ and $B b$ ) as well as $R_{\text {input }}$ $(14.8 \pm 11.0 \mathrm{M} \Omega$, from a mean of $525.8 \pm 121.8 \mathrm{M} \Omega$ to $540.6 \pm 129.1 \mathrm{M} \Omega ; P=0.2$; Fig. $1 B c$ ). Interestingly, we verified that neurons unresponsive to tolbutamide were significantly more depolarized than neurons responsive to tolbutamide $(-65.2 \pm 2.4 \mathrm{mV}$ vs. $-76.1 \pm 2.5 \mathrm{mV}$, respectively; $P=0.019$; Fig. $1 C$ ). Accordingly, we found a negative correlation between RMP and tolbutamide depolarization $\left(r^{2}=0.79 ; P<0.0001\right.$; Fig. $\left.1 D\right)$. On the other hand, no correlation between the change of $R_{\text {input }}$ induced by tolbutamide $\left(\Delta R_{\text {input }}\right)$ and initial $R_{\text {input }}\left(r^{2}=0.2 ; \quad P=0.19 ;\right.$ Fig. $\left.1 E\right)$ was observed. Therefore, we conclude that NTS neurons present with active $K_{\text {ATP }}$ channels, which can control RMP. Because tolbutamide-insensitive neurons had more depolarized $\mathrm{RMP}$, it is possible that $\mathrm{K}_{\mathrm{ATP}}$ channels are already closed by endogenous ATP in these neurons (see next section).

The depolarization evoked by tolbutamide is enough to trigger action potential firing in most responsive neurons when recorded in the absence of TTX (from 0.0 to $2.3 \pm 0.6 \mathrm{~Hz} ; n=14 ; P=0.0034$ ). Non-responsive neurons did not change their firing after perfusion of tolbutamide $(0.48 \pm 0.4 \mathrm{~Hz}$ vs. $0.63 \pm 0.6 \mathrm{~Hz} ; n=5$; $P=0.29$ ). As in TTX, the non-responsive neurons were more depolarized than the responsive neurons (responsive neurons: $-75.7 \pm 2.4 \mathrm{mV}$; non-responsive neurons: -66 . $3 \pm 2 \mathrm{mV} ; P=0.02, n=8$ and 5, respectively), and the depolarization was negatively correlated with the membrane potential $\left(r^{2}=0.59 ; P=0.0001\right)$.

To test whether non-responsive neurons express $K_{\text {ATP }}$ channels, we tested the effect of the $\mathrm{K}_{\text {ATP }}$ activator diazoxide (200 $\mu \mathrm{M} ; n=7$, five animals) on the RMP of NTS neurons. Diazoxide produced a fast and partially reversible hyperpolarization of almost all NTS neurons tested $(-8.8 \pm 2.1 \mathrm{mV}$, from a mean of $-73.7 \pm 1.7 \mathrm{mV}$ to $-82.6 \pm 3.3 \mathrm{mV} ; P=0.005$; washout: $-79.2 \pm 3.1 \mathrm{mV}$; $P=0.0012$; Fig. $2 A a$ and $A b$ ). Diazoxide also decreased $R_{\text {input }}$ significantly $(-230.4 \pm 87.7 \mathrm{M} \Omega$, from a mean of $532.3 \pm 103.7 \mathrm{M} \Omega$ to $301.9 \pm 65.3 \mathrm{M} \Omega ; P=0.04$; Fig. 2Ac), in accordance with the opening of an ion channel, but the reversal of this effect was not significant $(400.3 \pm 116.5 \mathrm{M} \Omega ; P=0.13)$. In contrast to the effect 
with tolbutamide, we observed an effect of diazoxide in both depolarized and hyperpolarized NTS neurons. In fact, no correlation was observed between the effect of diazoxide on membrane potential and RMP $\left(r^{2}=0.24\right.$; $P=0.2$; Fig. $2 B$ ). However, we found a significant correlation between the change of $R_{\text {input }}$ induced by diazoxide $\left(\Delta R_{\text {input }}\right)$ and initial $R_{\text {input }}\left(r^{2}=0.61 ; P=0.04\right.$;
Fig. 2C), suggesting that the magnitude of the effect of diazoxide is affected by the amount of $\mathrm{K}_{\mathrm{ATP}}$ channels blocked. Thus, because diazoxide can open blocked $\mathrm{K}_{\text {ATP }}$ channels, we conclude that NTS neurons have $\mathrm{K}_{\mathrm{ATP}}$ channels blocked at rest and that modulation of $K_{\text {ATP }}$ channels can affect RMP of NTS neurons bidirectionally.
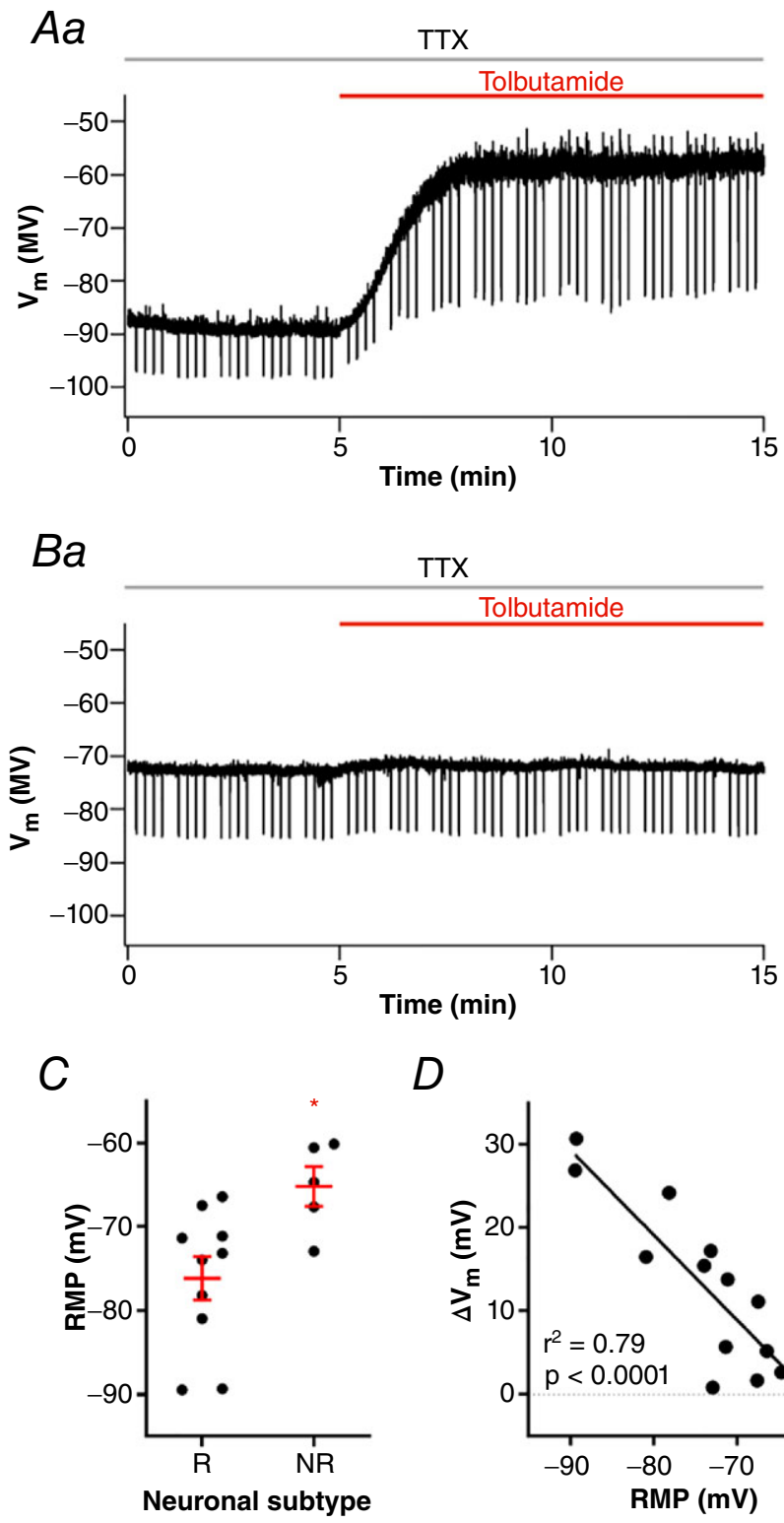

$D$

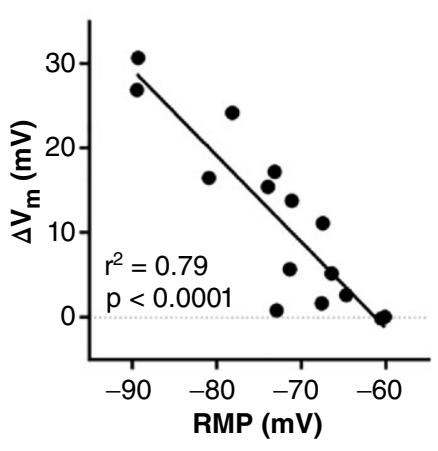

$b$

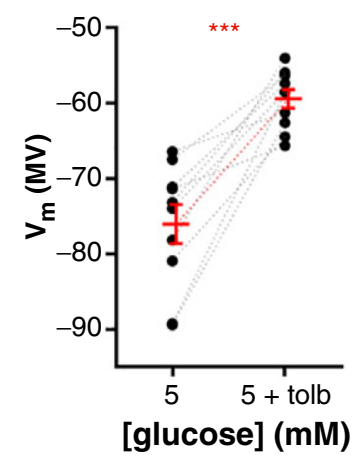

$b$

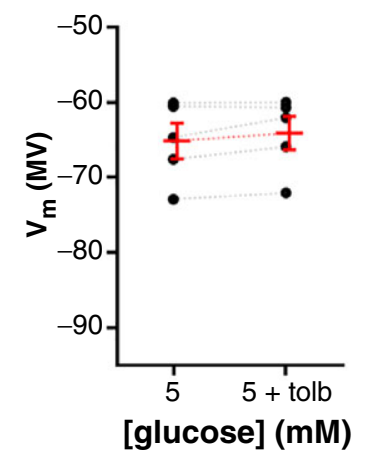

C

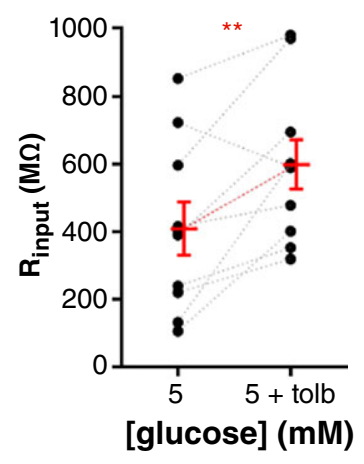

C

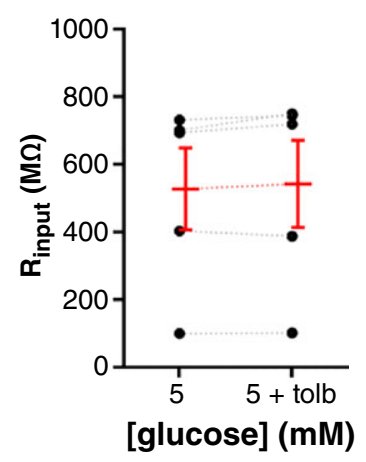

$E$

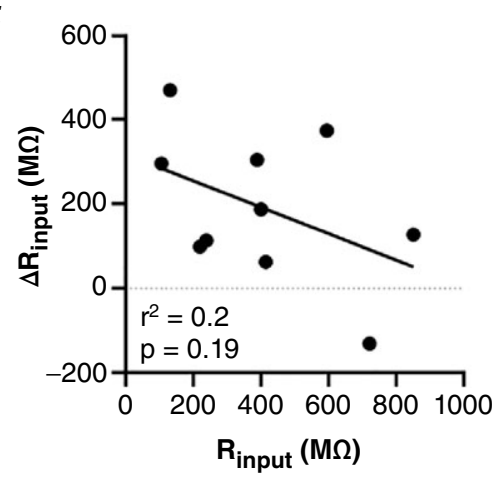

Figure 1. NTS neurons present active $\mathrm{K}_{\text {ATP }}$ channels $A$, representative recording of a neuron responsive to tolbutamide $(A a)$ and summary of the tolbutamide effect on membrane potential $\left(V_{\mathrm{m}} ; A b\right)$ and input resistance $\left(R_{\text {input }} ; A c\right)$ of neurons. $B$, representative recording of a neuron unresponsive to tolbutamide $(B a)$ and summary of the tolbutamide effect on $V_{m}(B b)$ and $R_{\text {input }}(B C)$ of neurons. $C$, comparison of the resting membrane potential (RMP) between neurons responsive (R) and unresponsive (NR) to tolbutamide. $D$, linear correlation between the change of $V_{m}$ induced by tolbutamide and the RMP of neurons. $E$, linear correlation between the change of $R_{\text {input }}$ induced by tolbutamide and the basal $R_{\text {input }}$ of neurons. Tolb, tolbutamide; TTX, tetrodotoxin. ${ }^{*} P<0.05$; ${ }^{* *} P<0.01$; ${ }^{* * *} P<0.001$. [Colour figure can be viewed at wileyonlinelibrary.com] 
Most NTS neurons in $5 \mathrm{mM}$ external glucose depolarize in response to low glucose aCSF

NTS neurons are involved in the counter-regulatory response to hypoglycaemia (Lamy et al. 2014). We showed that partially blocked $\mathrm{K}_{\mathrm{ATP}}$ channels are present in NTS neurons, and thus they can be subjected to modulation by the metabolic ATP/ADP ratio. Other groups showed that a fraction of NTS neurons changed membrane potential in response to changes in extracellular glucose. The effect of diazoxide suggests the existence of $\mathrm{K}_{\text {ATP }}$ channels blocked in our basal conditions. We then tested if perfusion of a low external glucose solution could produce hyperpolarization of NTS neurons by activation of $\mathrm{K}_{\mathrm{ATP}}$ channels, caused by a reduction of the ATP/ADP levels. We then perfused the NTS neurons incubated in $5 \mathrm{mM}$ glucose with a solution containing low glucose $(0.5 \mathrm{mM})$, a concentration that can be achieved in the CSF during periods of hypoglycaemia (Seaquist et al. 2001) and recorded the membrane potential. Surprisingly we found that perfusion of NTS neurons ( $n=37,23$ animals) with a low glucose solution depolarized most of NTS neurons (30 neurons; $81 \%)$. In these neurons, the RMP was depolarized after perfusion of low glucose aCSF by $9.3 \pm 1.0 \mathrm{mV}$, from
$-74.3 \pm 1.6 \mathrm{mV}$ to $-65.0 \pm 1.7 \mathrm{mV}(P<0.0001$; Fig. $3 \mathrm{Aa}$ and $A b)$. This effect took on average $383 \pm 18 \mathrm{~s}$ to reach its peak, being reversible in most neurons $(70 \%)$, and the RMP after returning to $5 \mathrm{mM}$ glucose was $-71.3 \pm 1.9 \mathrm{mV}$ $(P<0.0001)$.

Depolarization induced by low glucose triggered action potential (AP) firing in 16 of 28 silent neurons (57\%; $0.6 \pm 0.2 \mathrm{~Hz} ; P=0.007)$, and an increase in AP frequency in the only two spontaneously active neurons (from a mean of $3.3 \pm 2.7 \mathrm{~Hz}$ to $8.4 \pm 2.0 \mathrm{~Hz}$ in low glucose). Surprisingly, only a single cell $(3 \%)$ was hyperpolarized during perfusion with low glucose solution, from $-60 \mathrm{mV}$ to $-68 \mathrm{mV}$, and this effect was partially reversed (41\%) on the reinstatement of $5 \mathrm{mM}$ external glucose. Finally, six neurons $(16 \%)$, were considered unresponsive to low glucose with a mean RMP in $5 \mathrm{mM}$ glucose of $-64.1 \pm 2.0 \mathrm{mV}$, and of $-63.1 \pm 1.6 \mathrm{mV}$ after $0.5 \mathrm{mM}$ glucose, a difference of $1.0 \pm 0.7 \mathrm{mV} ; P=0.2$; Fig. $3 \mathrm{Ba}$ and $B b$ ).

To test the dependence on activation of voltage-gated sodium channels for low glucose sensing, we performed the low glucose challenge in the presence of TTX $(0.5 \mu \mathrm{M})$ in a second set of NTS neurons $(n=23$ cells, 11 animals). Again, we identified three types of responses.
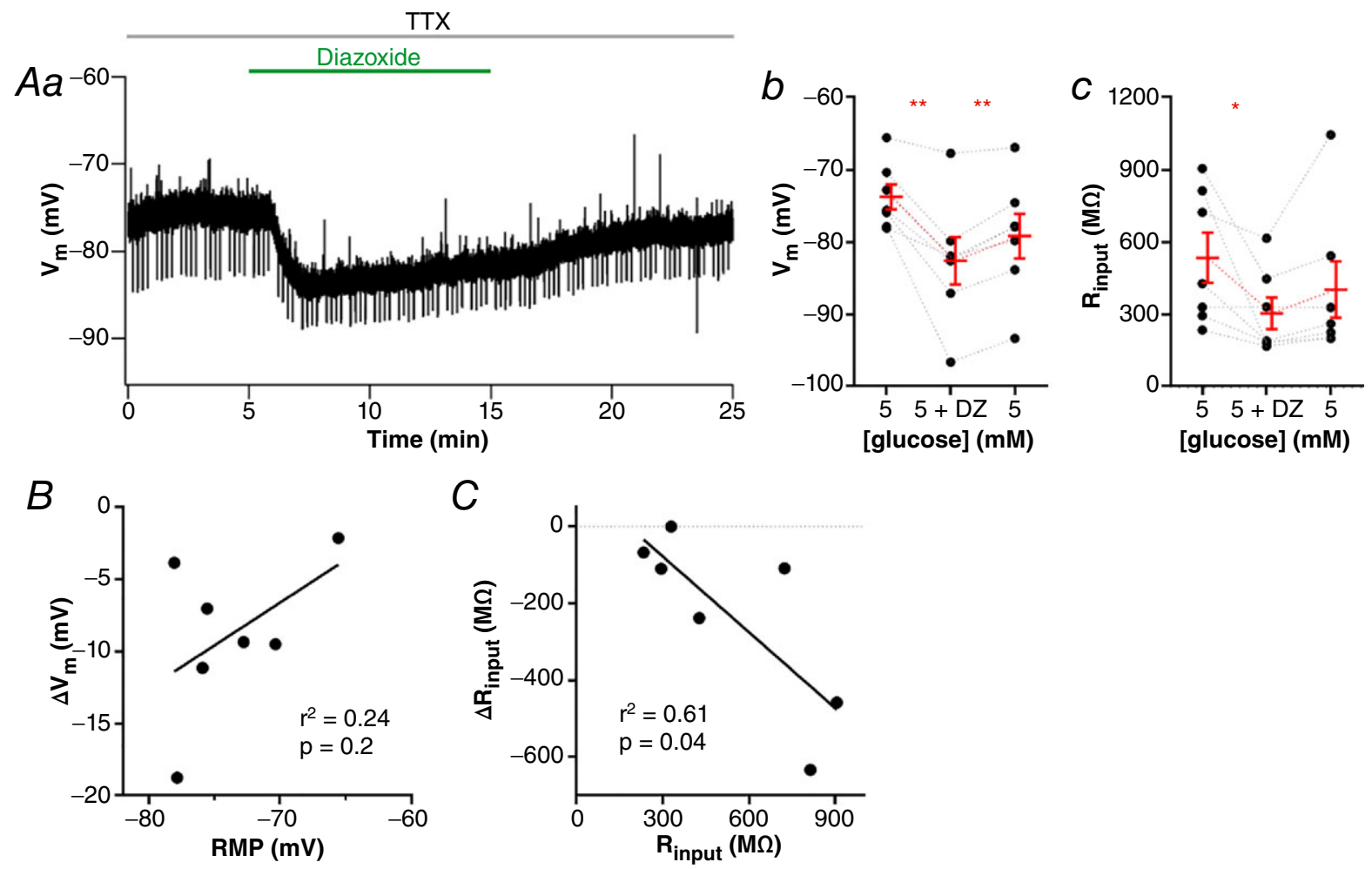

Figure 2. K $\mathrm{K}_{\text {ATP }}$ channels control the resting membrane potential of NTS neurons $A$, diazoxide induces a fast and partially reversible hyperpolarization of neurons, as shown by a representative recording $(A a)$. The graphs show the summary of the diazoxide effect on membrane potential $\left(V_{m} ; A b\right)$ and input resistance $\left(R_{\text {input }} ; A C\right)$ of neurons. $B$, linear correlation between the change of $V_{\mathrm{m}}$ induced by diazoxide and the resting membrane potential (RMP) of neurons. $C$, linear correlation between the change of $R_{\text {input }}$ induced by diazoxide and the basal $R_{\text {input }}$ of neurons. DZ, diazoxide; TTX, tetrodotoxin. ${ }^{*} P<0.05$; ${ }^{* *} P<0.01$. [Colour figure can be viewed at wileyonlinelibrary.com] 
Fourteen cells $(61 \%)$ were depolarized after low glucose by $8.8 \pm 1.0 \mathrm{mV}$, from a mean of $-79.1 \pm 1.6 \mathrm{mV}$ to $-70.3 \pm 1.3 \mathrm{mV}(P<0.0001$; Fig. $4 A a$ and $A b)$, and took, on average, $348 \pm 18 \mathrm{~s}$ to peak. This effect was reversible in most neurons $(71 \%)$, and the RMP after returning to $5 \mathrm{mM}$ glucose was $-77.0 \pm 1.8 \mathrm{mV}(P<0.0001)$. A single cell $(4 \%)$ was hyperpolarized by $-5.5 \mathrm{mV}$, from $-72.1 \mathrm{mV}$ to $-77.6 \mathrm{mV}$ in low glucose, and this effect was reversed after returning to $5 \mathrm{mM}$ glucose. Lastly, eight cells (35\%) were unresponsive to low glucose solution $(1.1 \pm 0.5 \mathrm{mV}$; from a RMP of $-66.9 \pm 1.6 \mathrm{mV}$ to $-65.8 \pm 1.7 \mathrm{mV}$; $P=0.07$; Fig. $4 B a$ and $B b$ ). Both depolarizing effect and latency to peak response were not different from those observed in experiments conducted with no TTX $(P=0.7$, and $P=0.2$, respectively), and as in normal aCSF, most neurons depolarized in low glucose solution $(84 \%$ in normal aCSF, and $65 \%$ in TTX). We conclude that the depolarization triggered by low glucose is not dependent on the activation of voltage-gated sodium channels and action potential firing. Most of the experiments shown from now on were performed in the presence of TTX.

Lamy et al. (2014) found that the membrane depolarization induced by low glucose in GABAergic NTS neurons was accompanied by an increase in the membrane input resistance $\left(R_{\text {input }}\right)$ caused by inhibition of a potassium leak conductance. Contrary to the observation of Lamy et al. (2014), we verified that NTS neurons depolarized by low glucose showed a significant decrease in $R_{\text {input }}(-101.1 \pm 37.8 \mathrm{M} \Omega$, from a mean of $440.3 \pm 61.6 \mathrm{M} \Omega$ to $339.2 \pm 40.0 \mathrm{M} \Omega ; P=0.02$; Fig. $4 A c)$. In contrast to the effects observed with the membrane potential, these effects did not reverse on reinstatement of $5 \mathrm{mM}$ glucose $(P=0.7)$. Additionally, neurons unresponsive to low glucose also showed a decrease in $R_{\text {input }}(-80.3 \pm 13.2 \mathrm{M} \Omega$, from a mean of $522.9 \pm 71.1 \mathrm{M} \Omega$ to $442.6 \pm 61.6 \mathrm{M} \Omega ; P=0.0005$; Fig. $4 B c$ ). As in responsive neurons, $R_{\text {input }}$ did not reverse after returning the neurons to $5 \mathrm{mM}$ glucose aCSF in non-responsive cells $(P=0.5)$. Interestingly, the single neuron hyperpolarized by low glucose in TTX showed a robust decrease in $R_{\text {input }}(-629.2 \mathrm{M} \Omega$, from $900.5 \mathrm{M} \Omega$ to 271.3 $\mathrm{M} \Omega$ ), suggesting the opening of $\mathrm{K}_{\mathrm{ATP}}$ channels.

Interestingly, we observed that the depolarization caused by low glucose was strongly correlated with neuronal RMP $\left(r^{2}=0.53 ; P<0.0001\right.$; Fig. $\left.5 A\right)$; the more negative the RMP, the greater the membrane potential change in response to low glucose. We then compared the RMP between responsive and non-responsive neurons, and found that the RMP of non-responsive cells was significantly more depolarized than responsive cells $(-66.8 \pm 1.6 \mathrm{mV}$ vs. $-78.6 \pm 1.6 \mathrm{mV}$, respectively; $P=0.0001$; Fig. 5C). On the other hand, we found a weak inverse correlation between the low glucose effects on $\Delta V_{\mathrm{m}}$ and $\Delta R_{\text {input }}\left(r^{2}=0.18, P=0.04\right.$; Fig. $\left.5 B\right)$. We conclude that the depolarization induced by low external glucose uses a voltage-dependent mechanism, which might involve the opening of a depolarizing membrane conductance.
Figure 3. Most NTS neurons depolarize in response to a low glucose challenge $A$, subset of neurons depolarized by low glucose, as shown by representative recording of a responsive neuron showing a reversible depolarization and increased firing activity induced by low glucose $(A a)$ and summary of the low glucose effect on the membrane potential $\left(V_{\mathrm{m}}\right)$ of neurons $(A b)$. $B$, subset of neurons unresponsive to low glucose, as shown by a representative recording $(B a)$ and summary of the low glucose effect on the $V_{m}$ of neurons $(B b)$. ${ }_{* * * *} P<0.0001$. [Colour figure can be viewed at wileyonlinelibrary.com]
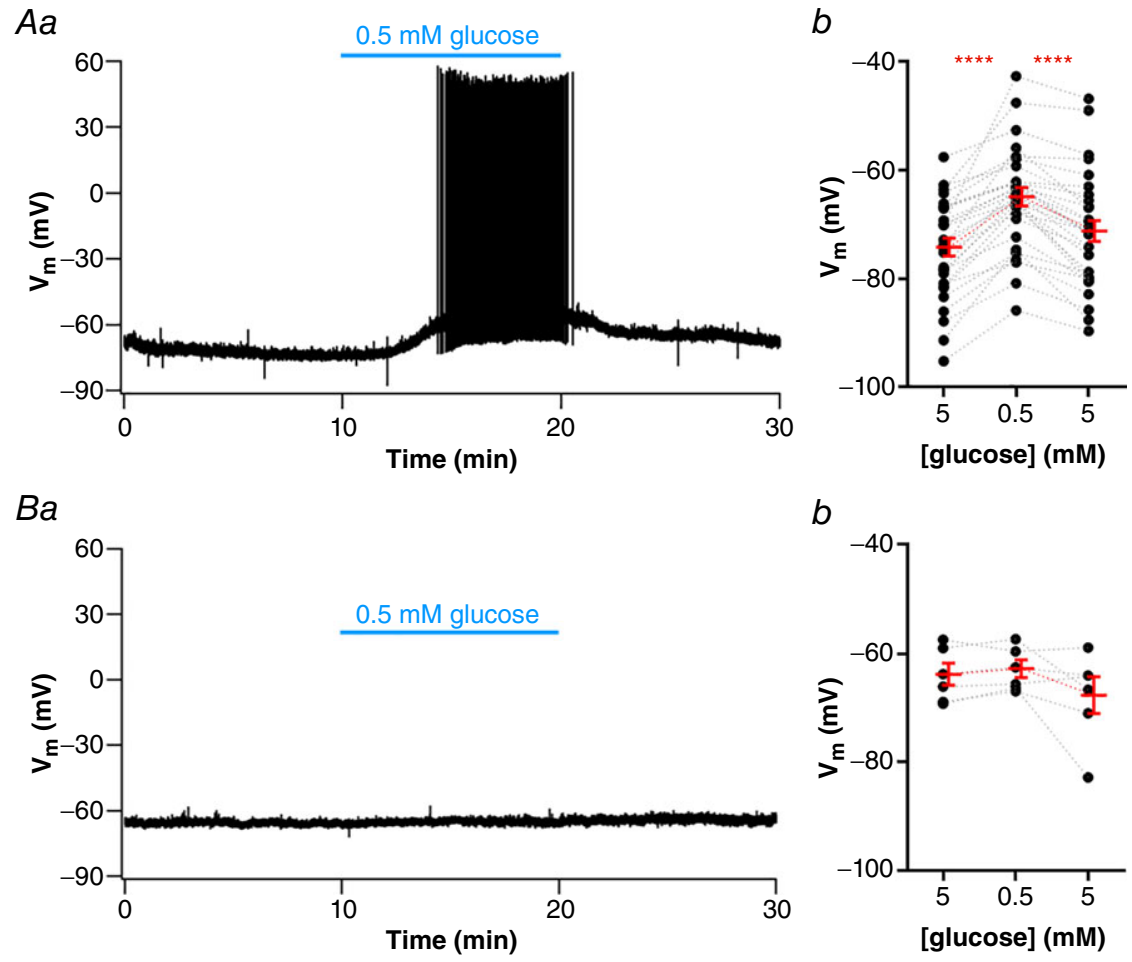
In order to discover whether the decrease in glucose is being sensed by the recorded neuron itself, or is signalled by neighbouring glia as previously suggested (McDougal et al. 2013), we added $3 \mathrm{mM}$ of glucose to the recording pipette and measured the response of the neuron to low glucose ( $n=6$, four animals). In this condition, perfusion of low glucose external solution did not change the RMP of NTS neurons $(-1.0 \pm 0.64 \mathrm{mV}$; from a mean of $-76.3 \pm 3.6 \mathrm{mV}$ to $-75.3 \pm 3.2 \mathrm{mV} ; P=0.2$; Fig. 6A), showing that the drop in external glucose is being sensed by the recorded neuron. Interestingly, these neurons presented a small but significant drop in $R_{\text {input }}$,
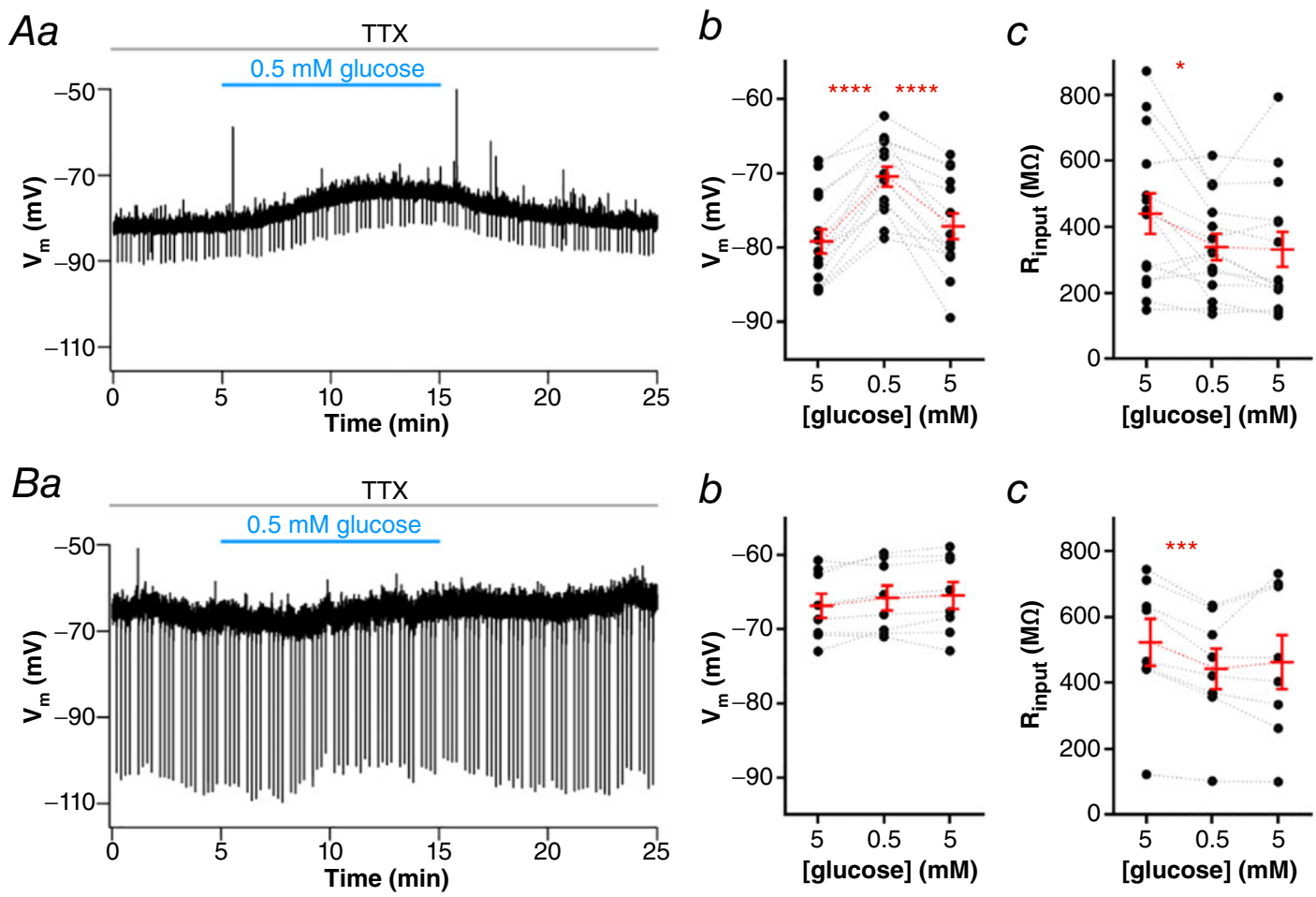

Figure 4. Low glucose sensing of NTS neurons is independent of action potential-dependent neurotransmission

$A$, subset of neurons depolarized by low glucose in the presence of tetrodotoxin (TTX), as shown by representative recording of a responsive neuron showing a reversible depolarization and decreased input resistance $\left(R_{\text {input }}\right)$ induced by low glucose $(A a)$. The graphs show the summary of the low glucose effect on membrane potential $\left(V_{m} ; A b\right)$ and $R_{\text {input }} ; A c$ ) of neurons. $B$, subset of neurons unresponsive to low glucose in the presence of TTX, as shown by a representative recording $(B a)$. The graphs show the summary of the low glucose effect on $\left(V_{m} ; B b\right)$ and $R_{\text {input; }}$; $B C$ ) of neurons. ${ }^{*} P<0.05$; ${ }^{* * *} P<0.001 ;{ }^{* * * *} P<0.0001$. [Colour figure can be viewed at wileyonlinelibrary.com]
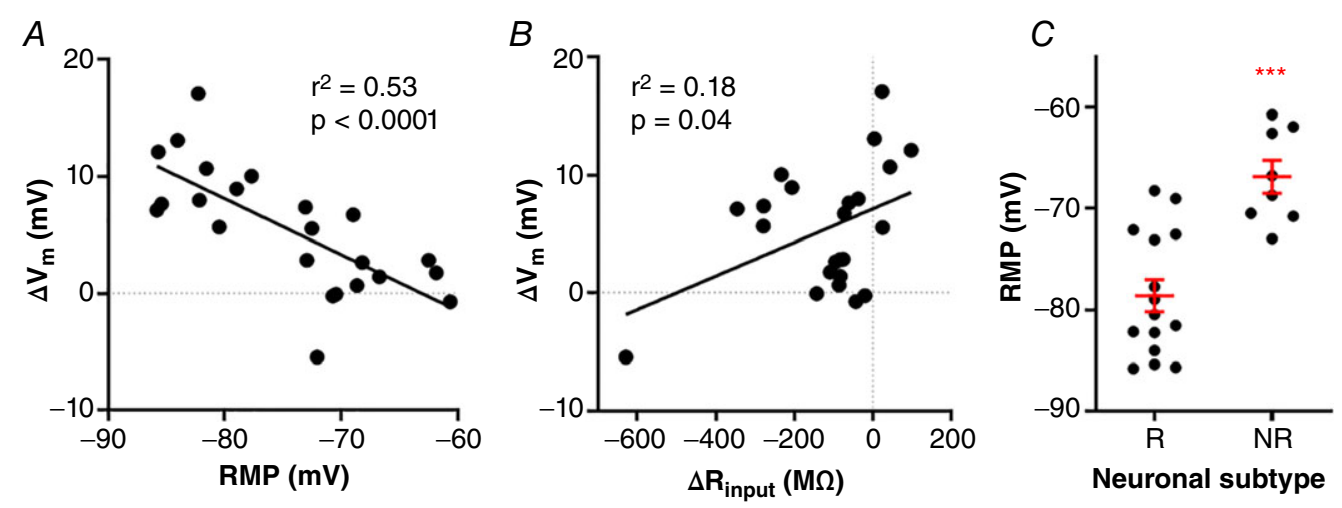

Figure 5. Low glucose-induced depolarization of NTS neurons is a voltage-dependent mechanism The graphs show the linear correlation between the change of membrane potential $\left(\Delta V_{m}\right)$ induced by low glucose and resting membrane potential (RMP; $A)$ and input resistance response $\left(\Delta R_{\text {input }} ; B\right)$ of neurons. $C$, comparison of the RMP between neurons responsive (R) and unresponsive (NR) to low glucose. ${ }^{* * *} P<0.001$. [Colour figure can be viewed at wileyonlinelibrary.com] 
from $353 \pm 59 \mathrm{M} \Omega$ to $323 \pm 64 \mathrm{M} \Omega(P=0.049)$. The RMP of the neurons with $3 \mathrm{mM}$ glucose was not significantly different from that of NTS neurons in $5 \mathrm{mM}$ glucose $(P=0.6$; Fig. $6 B)$, and neither was the $R_{\text {input }}$ $(P=0.18)$, showing that the presence of glucose in the pipette did not depolarize the neuron. In fact, when we compared the RMP of the non-responsive neurons, which were more depolarized, with the RMP in $3 \mathrm{mM}$ internal glucose, we found a significant difference $(-66.8 \pm 1.6 \mathrm{mV}$ vs. $-76.3 \pm 3.6 \mathrm{mV}$, respectively; $P=0.02$; Fig. $6 C$ ), confirming that the internal glucose is not depolarizing the NTS neurons.

The age of the animals affects RMP and the response to low glucose

Although most of our recordings were performed on 3 -week-old animals, we used animals at 6 and 11 weeks old as well. We then compared whether the age of animals could influence $\mathrm{n}$ the sensitivity to low glucose. We found that the response to low glucose in responsive neurons was similar in slices from 3-, 6- and 11-week-old rats (3 weeks: $8.4 \pm 0.7 \mathrm{mV}$; 6 weeks: $11.4 \pm 2.1 \mathrm{mV} ; 11$ weeks: $8.5 \pm 1.8 \mathrm{mV} ; P=0.22 ; n=27,11$ and 6 , respectively), but we found a bigger proportion of non-responsive neurons in slices from 11-week-old rats than from 3-week-old rats (42\% vs. $20 \% ; P=0.0012)$ and 6 -week-old rats $(15 \%$; $P<0.001)$. Accordingly, the RMP of the neurons from 11-week-old rats was more depolarized than from 3-and 6-week-old rats (3 weeks: $-74.8 \pm 1.4 \mathrm{mV}$; 6 weeks: $-74.6 \pm 2.7 \mathrm{mV} ; 11$ weeks: $-66.9 \pm 2.1 \mathrm{mV} ; 3$ weeks vs. 6 weeks, $P=0.8 ; 3$ weeks vs. 11 weeks, $P=0.007$; 6 weeks vs. 11 weeks, $P=0.03 ; n=35,13$ and 12 for 3 weeks, 6 weeks and 11 weeks, respectively).

Because the effect of tolbutamide was also voltage dependent, we also compared the number of tolbutamidesensitive neurons in slices from 3- and 11-week-old rats. Similarly, we found more tolbutamide-non-responsive neurons in 11-week-old animals than in 3-week-old animals ( $45 \%$ of non-responsive neurons in 11-week-old animals vs. $13 \%$ from 3 -week-old animals; $P<0.0001$, $n=20$ and 15, respectively). The RMP of tolbutamide-non-responsive neurons from 11-week-old animals was more depolarized than that of responsive neurons in both age groups $(P=0.035)$, but the depolarization induced by tolbutamide was not significantly different in both groups (3 weeks: $14.6 \pm 2.1 \mathrm{mV} ; 6$ weeks: $16.5 \pm 2.2 \mathrm{mV} ; P=0.5)$. We conclude that NTS neurons from 11-week-old animals are more depolarized than from 3-or 6-week-old animals, and for this reason, they express more low glucose and tolbutamide unresponsive neurons.

\section{Perfusion with low glucose solution produces an inward current}

We then investigated which ionic conductance is responsible for the depolarization induced by low glucose. Lamy et al. (2014) showed that in GABAergic neurons from mice NTS, low glucose solution inhibits a potassium leak conductance, leading to depolarization of the neuron. On the other hand, Balfour \& Trapp (2007) reported in NTS neurons from rats, an inward current activated by low glucose in half of the neurons, and an inhibition of a potassium conductance or a parallel inward current in the other half of recorded neurons, suggestive of an inhibition of the current of the $\mathrm{Na}^{+} / \mathrm{K}^{+}$-ATPase. We performed current-voltage relationships voltage-clamp recordings in NTS neurons ( $n=8$, five animals), and observed a similar effect to that observed by Balfour \& Trapp (2007), with low glucose aCSF perfusion increasing membrane conductance (measured as the slope of the curve) from $3.1 \pm 0.1 \mathrm{nS}$ to $4.8 \pm 0.1 \mathrm{nS}$, and this increase was significantly different $(P<0.0001)$. Low glucose produces a small inward current $(-57.6 \pm 26 \mathrm{pA}$ at $-85 \mathrm{mV})$ with a reversal around $-51 \mathrm{mV}$ (Fig. $7 A$ and $B$ ). Interestingly, the reversal potential is around the membrane potential where the effect of low glucose is not observed. Thus, we conclude that in NTS neurons from rats, the main mechanism of depolarization is the development of an inward current with a reversal potential more positive than the RMP. This is in accordance with the decrease in the $R_{\text {input }}$ observed
Figure 6. The presence of glucose in the pipette solution prevents the detection of low external glucose by NTS neurons

$A$, summary of the low glucose effect on the membrane potential $\left(V_{m}\right)$ of neurons recorded with $3 \mathrm{mM}$ glucose pipette solution. $B$, comparison of the resting membrane potential (RMP) between neurons recorded with the regular pipette solution and the $3 \mathrm{mM}$ glucose pipette solution. C, comparison of the RMP between unresponsive neurons recorded with the regular pipette solution and the $3 \mathrm{mM}$ glucose pipette solution. Glc, glucose. ${ }^{*} P<0.05$. [Colour figure can be viewed at wileyonlinelibrary.com]
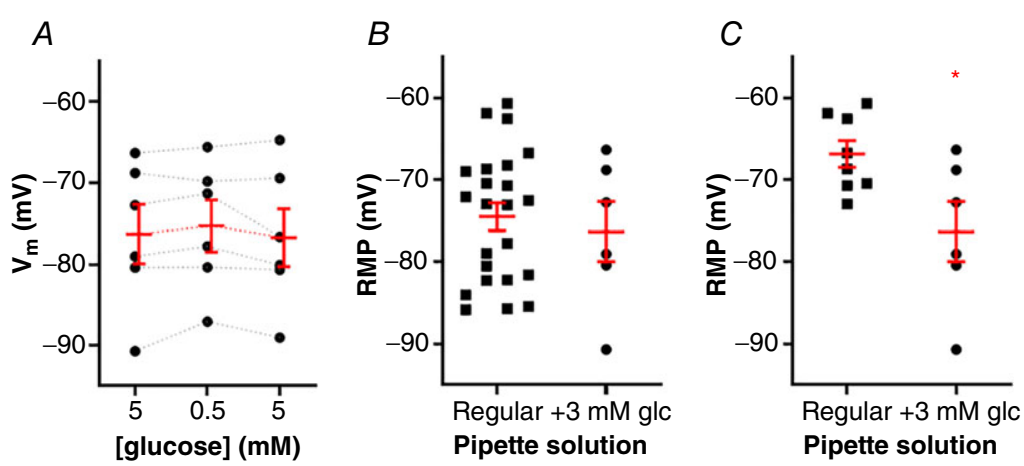
after low glucose external solution in NTS neurons and with the voltage dependency of the depolarization, which is near the reversal potential of this current.

\section{Depolarization by blocking $K_{\text {ATP }}$ channels inhibits the effect of low glucose aCSF}

We showed that NTS neurons have $\mathrm{K}_{\text {ATP }}$ channels opened at rest and that these channels could strongly affect RMP if inhibited, as demonstrated by the depolarization triggered by their antagonist tolbutamide. Additionally, we found that perfusion with low glucose aCSF depolarized the RMP of these neurons, but this effect decreased with RMP depolarization, and the non-responsive neurons were more depolarize than the responsive neurons. Thus, two opposite signals, low glucose and block of $\mathrm{K}_{\text {ATP }}$ channels, produce a similar effect, the membrane depolarization. Because the depolarization induced by low external glucose is more prominent in more hyperpolarized neurons, in a situation where $\mathrm{K}_{\mathrm{ATP}}$ channels are blocked, as in a high ATP/ADP ratio, we hypothesized that the neuron could not sense the drop in external glucose.

In order to test this hypothesis, we first tested if a drop in the external glucose could further depolarize a neuron depolarized by tolbutamide. For this experiment, we first tested the responsiveness of the neuron to low glucose, then washed the neuron, and then applied tolbutamide. We found that all neurons responsive to low glucose were responsive to tolbutamide (Fig. 8Aa and $A b$ ). Low glucose reversibly depolarized the RMP by $9.1 \pm 2.2 \mathrm{mV}(P=0.01$; $n=5)$, and application of tolbutamide was able to depolarize the RMP by $18.5 \pm 3.0 \mathrm{mV}(P=0.004)$, showing that neurons responsive to low glucose have $\mathrm{K}_{\mathrm{ATP}}$ channels opened at rest. However, in these neurons, application of low glucose aCSF in the presence of tolbutamide induced only a small, but significant, membrane depolarization (2.0 $\pm 0.3 \mathrm{mV} ; P=0.002)$, which was smaller than the depolarizing response before tolbutamide application $(P=0.03$; Fig. $8 A c)$. This result suggests that depolarization induced by blocking $\mathrm{K}_{\mathrm{ATP}}$ channels blunts the neuron's response to low external glucose.

To test if this effect was due only to the membrane depolarization induced by tolbutamide, we repeated this protocol, but hyperpolarized the neurons by injecting DC current after the application of tolbutamide, and tested the effect of low glucose aCSF $(n=5$; Fig. $8 B a)$. Again, we found that the membrane potential is depolarized by both low glucose $(4.4 \pm 0.7 \mathrm{mV} ; P=0.003)$ and tolbutamide $(12.2 \pm 2.8 \mathrm{mV} ; P=0.001)$. Next, the injection of -30 to $-50 \mathrm{pA}$ of DC current hyperpolarized the membrane potential (from a mean of $-60.5 \pm 0.8 \mathrm{mV}$ to $-76.9 \pm 1.3 \mathrm{mV}$ ), and in this condition, low glucose aCSF was able to depolarize the membrane by more than $2 \mathrm{mV}$ in three out of five NTS neurons (average for all neurons: $6.0 \pm 2.4 \mathrm{mV} ; P=0.06$ ). However, this depolarization was similar to that observed in the absence of tolbutamide $(P=0.6$; Fig. $8 B b)$, showing that tolbutamide is not able to occlude the effect of low glucose if the membrane is hyperpolarized to values similar to the RMP in most NTS neurons.

Interestingly, all neurons unresponsive to low glucose aCSF $(0.6 \pm 0.5 \mathrm{mV} ; P=0.3 ; n=5)$ were also not responsive to tolbutamide $(1.0 \pm 0.5 \mathrm{mV} ; P=0.1$; Fig. $8 C$ ). These neurons also had more depolarized RMPs in comparison to responsive neurons $(-65.7 \pm 1.9 \mathrm{mV} v s$. $-73.1 \pm 1.9 \mathrm{mV}$, respectively; $P=0.03$; Fig. $8 D$ ).

\section{Incubation with $10 \mathrm{mM}$ glucose aCSF increases RMP and reduces the number of neurons responsive to low glucose and tolbutamide}

Because most NTS neurons express open $\mathrm{K}_{\text {ATP }}$ channels at rest, which can depolarize the membrane when blocked, we asked whether NTS neurons incubated with a higher
A
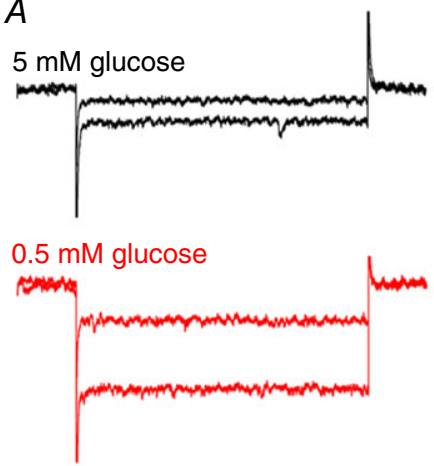

Low-glucose- induced current

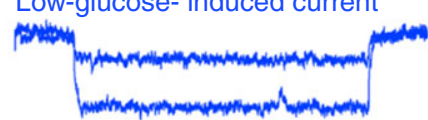

$25 \mathrm{pA}$

$100 \mathrm{~ms}$
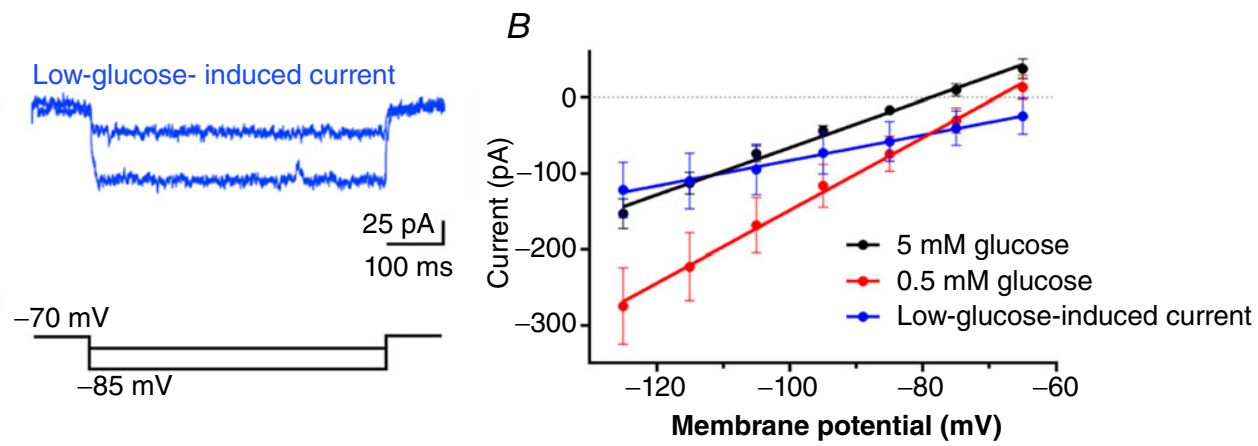

Figure 7. Low glucose-induced depolarization of NTS neurons is triggered by an inward current $A$, representative time course recordings of currents in response to voltage steps obtained in basal ( $5 \mathrm{mM}$ glucose; black) and low glucose $(0.5 \mathrm{mM}$; red) conditions, and the respective subtraction of currents (blue). $B$, linear regression of current-voltage relationship of neurons recorded in the conditions depicted in $A$. [Colour figure can be viewed at wileyonlinelibrary.com] 
glucose concentration could lead to more ATP production by the glycolytic/oxidative metabolism, blockage of the $\mathrm{K}_{\text {ATP }}$ channels, and thus membrane depolarization. For this experiment, we incubated the slices in an aCSF solution containing twice the concentration of glucose $(10 \mathrm{mM})$. We found that NTS neurons incubated in $10 \mathrm{mM}$ glucose aCSF ( $n=17$, eight animals) had more depolarized RMPs than neurons incubated in $5 \mathrm{mM}$ glucose aCSF $(-69.0 \pm 1.5 \mathrm{mV}$ vs. $-74.5 \pm 1.7$, respectively; $P=0.02$; Fig. $9 A$. This suggests that NTS neurons incubated in $10 \mathrm{mM}$ glucose produce more ATP, which block $K_{\text {ATP }}$ channels and depolarize the membrane. Because the response to low glucose was blunted by membrane depolarization, we hypothesized that NTS neurons incubated in $10 \mathrm{mM}$ glucose would be less responsive to a low glucose solution than neurons
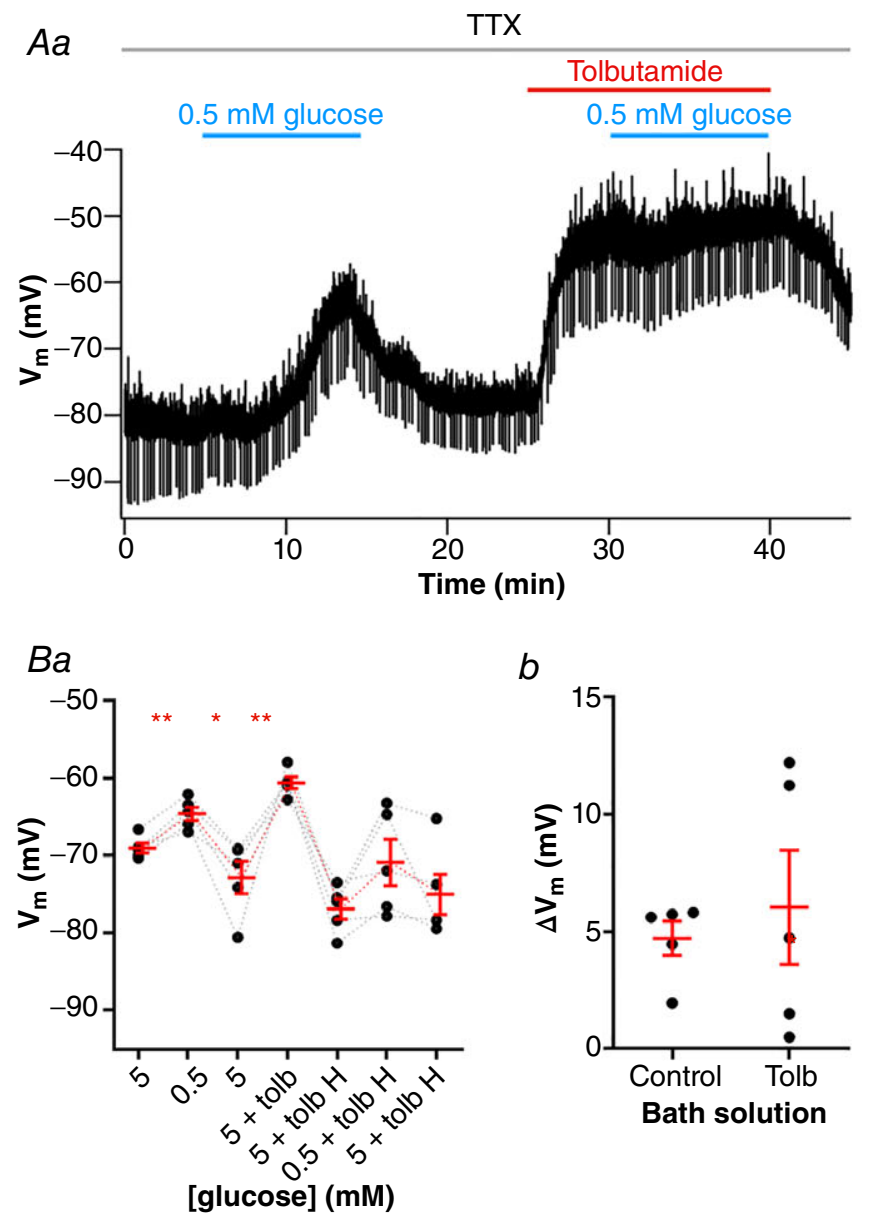

incubated in $5 \mathrm{mM}$ glucose. In order to test this, we sequentially applied a low glucose solution, followed, after returning to $10 \mathrm{mM}$ glucose, by application of tolbutamide. We found that only three out of 16 cells (19\%) were reversible depolarized by perfusion of $0.5 \mathrm{mM}$ glucose $(11.2 \pm 0.8 \mathrm{mV}$, from a mean of $-74.0 \pm 3.7 \mathrm{mV}$ to $-62.8 \pm 3.3 ; P=0.0008$; Fig. $9 B$ and $C$ ). This depolarization was similar to what found in neurons incubated in $5 \mathrm{mM}$ external glucose $(P=0.2)$. Interestingly, the time course of the depolarization was slower, taking on average $435 \pm 39 \mathrm{~ms}$ to peak in contrast to $349 \pm 19 \mathrm{~ms}$ in $5 \mathrm{mM}$ glucose aCSF $(P=0.048)$. After returning to $10 \mathrm{mM}$ glucose, the RMP returned to a value similar to the original RMP $(-72.7 \pm 5.3 \mathrm{mV} ; P=0.9)$. Additionally, we sequentially applied tolbutamide which triggered a strong depolarization of $18.4 \pm 1.6 \mathrm{mV}$
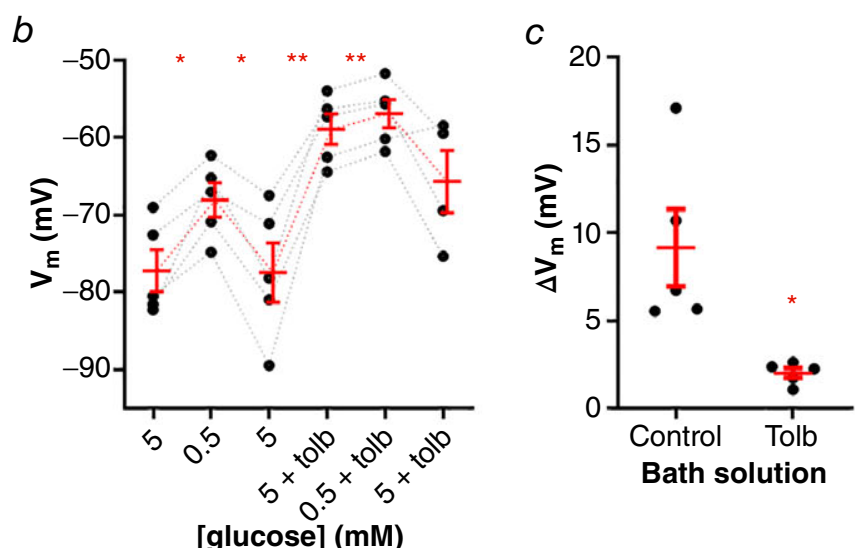

C
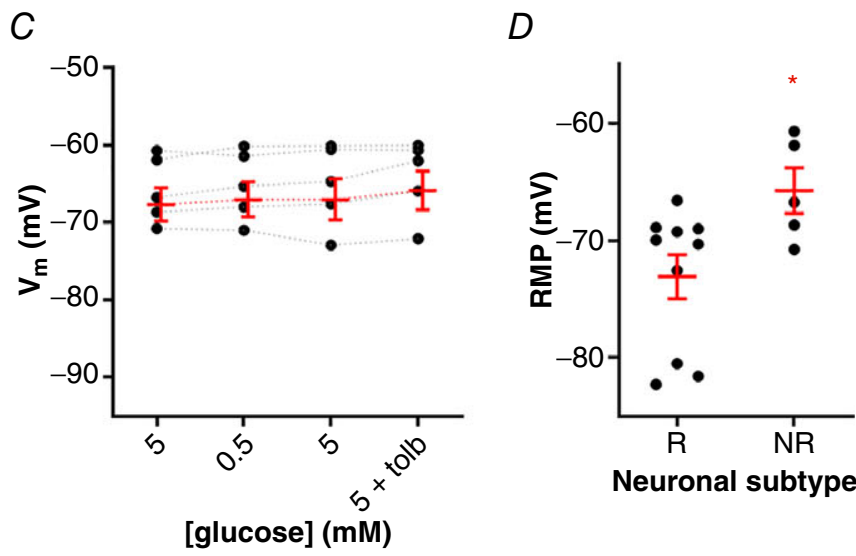

\footnotetext{
Figure 8. The occlusion of $\mathrm{K}_{\text {ATP }}$ channels suppresses the low glucose-induced depolarization of NTS neurons

$A$, application of tolbutamide blunts the depolarizing effect induced by a low glucose challenge, as shown by a representative recording $(A a)$. Neurons responsive to low glucose are also depolarized by tolbutamide $(A b)$, but this effect occludes the low glucose sensing $(A c)$. $B$, hyperpolarization of neurons responsive to low glucose $(B a)$ prevents the effect of tolbutamide in blunting the low glucose sensing $(B b)$. $C$, neurons unresponsive to low glucose also do not respond to tolbutamide application. $D$, comparison of the resting membrane potential (RMP) between neurons responsive (R) and unresponsive (NR) to both low glucose and tolbutamide. $H$, hyperpolarization; Tolb, tolbutamide; TTX, tetrodotoxin; $V_{m}$, membrane potential. ${ }^{*} P<0.05 ; * * P<0.01$. [Colour figure can be viewed at wileyonlinelibrary.com]
} 
$(P=0.007$; Fig. $9 B)$, a value similar to that produced by tolbutamide in $5 \mathrm{mM}$ glucose $(P=0.5)$. On the other hand, 13 neurons $(81 \%)$ were considered unresponsive to low glucose $(1.4 \pm 0.5 \mathrm{mV}$, from a mean of $-67.5 \pm 1.4 \mathrm{mV}$ to $-66.2 \pm 1.4 \mathrm{mV}$; Fig. $9 \mathrm{C}$ and $E$;), and had more depolarized RMPs compared to the responsive cells (responsive neurons: $-77.7 \pm 0.5 \mathrm{mV}$; unresponsive neurons: $-66.05 \pm 2.2 \mathrm{mV}$; $P=0.01$; Fig. 9D). Moreover, tolbutamide was applied in four of the unresponsive cells and did not induce significant membrane potential change $(0.8 \pm 0.3 \mathrm{mV} ; P=0.08$; Fig. $9 E)$. As in neurons incubated with $5 \mathrm{mM}$ glucose, we found a positive correlation between the effect of low glucose and RMP $\left(r^{2}=0.44\right.$, $P=0.005$; Fig. $9 F)$. The proportions of non-responsive cells were significantly bigger in $10 \mathrm{mM}$ glucose than in $5 \mathrm{mM}$ glucose ( $81 \%$ vs. 39\%; $P<0.0001$; Fig. 9 C).
The lack of effect of both low glucose and tolbutamide on the RMP of NTS neurons suggests that metabolic ATP is blocking $\mathrm{K}_{\text {ATP }}$ in these neurons when incubated in $10 \mathrm{mM}$ glucose, leading to the membrane depolarization and inhibition of the response to low glucose. To test this, we hyperpolarized the depolarized neurons (from $-71.3 \pm 3.5 \mathrm{mV}$ to $85.1 \pm 2.9 \mathrm{mV} ; n=5$ ) and applied sequentially low glucose and tolbutamide (Fig. 10A). Surprisingly, in hyperpolarized neurons, the response to low glucose was present but reduced when compared to regular responsive neurons $(3.2 \pm 1.1 \mathrm{mV}$ vs. $11.2 \pm 0.8 \mathrm{mV}$, respectively; $P=0.0004$; Fig. $10 B$ ), suggesting a diminished response to low glucose in neurons incubated in $10 \mathrm{mM}$ glucose. On the other hand, these neurons continued to be non-responsive to tolbutamide $(-2.4 \pm 1.1 \mathrm{mV}$, from $-83.0 \pm 1.2 \mathrm{mV}$
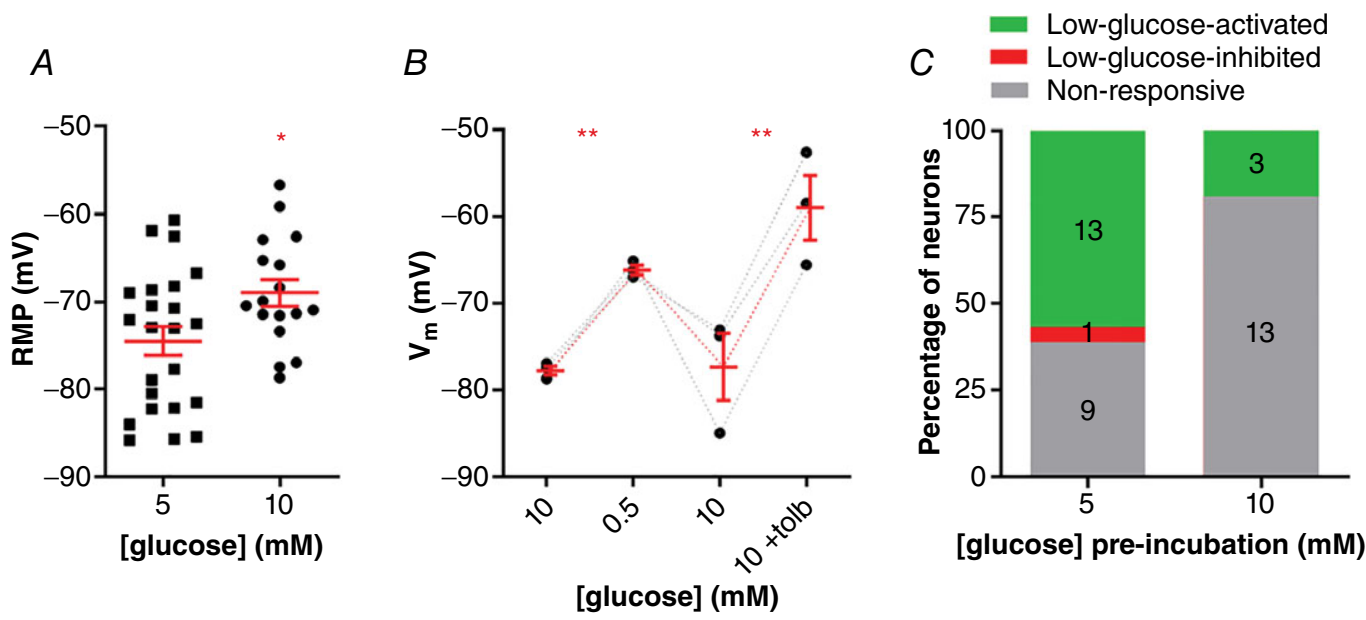

[glucose] pre-incubation ( $\mathrm{mM})$
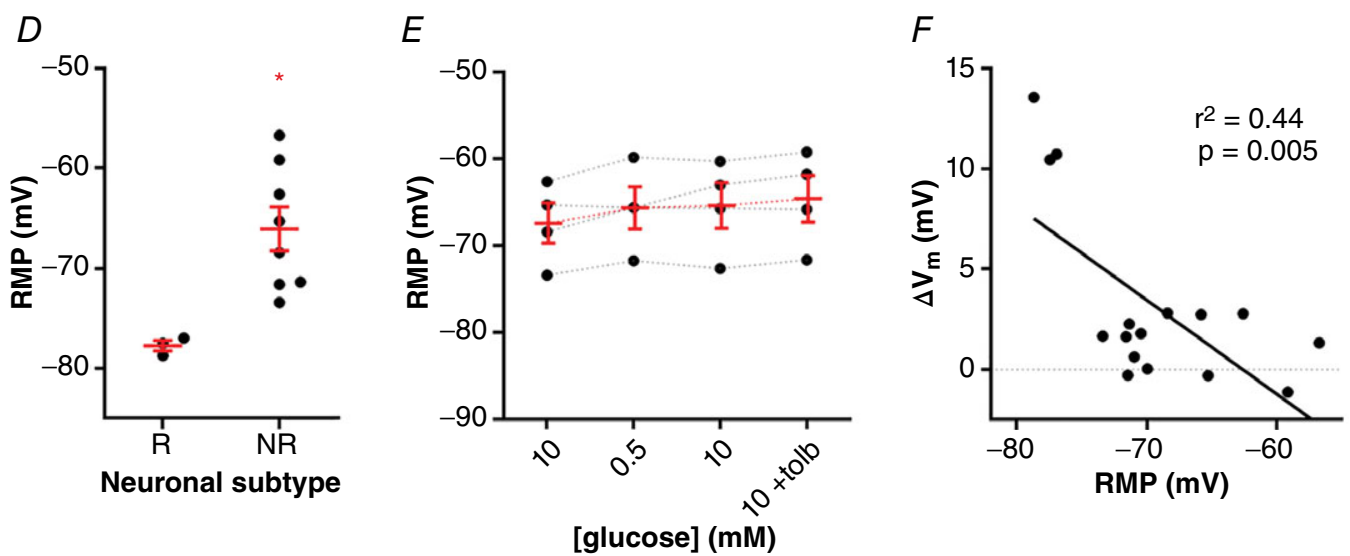

Figure 9. Incubation in high glucose $(10 \mathrm{mM})$ decreases the number of NTS neurons sensitive to low glucose

$A$, comparison of the resting membrane potential (RMP) between neurons incubated in $5 \mathrm{mM}$ and $10 \mathrm{mM}$ glucose. $B$, neurons incubated in high glucose that are responsive to low glucose are depolarized by tolbutamide application. C, comparison of the distribution of neurons pre-incubated in different glucose solutions according to their response to low glucose. $D$, comparison of the RMP of neurons incubated in high glucose that were responsive (R) or unresponsive (NR) to a low glucose challenge. $E$, neurons incubated in high glucose that are unresponsive to low glucose also do not respond to tolbutamide application. $F$, linear correlation between the change of membrane potential $\left(V_{m}\right)$ and the RMP of neurons incubated in high glucose. Tolb, tolbutamide. ${ }^{*} P<0.05 ;{ }^{*} P<0.01$. [Colour figure can be viewed at wileyonlinelibrary.com] 
to $-80.6 \pm 1.5 \mathrm{mV} ; P=0.1$; Fig. $10 A)$. Although some individual neurons presented a smaller response, they were much smaller than in $5 \mathrm{mM}$ glucose $(P=0.03$; Fig. 10C). These results are in accordance with the hypothesis that metabolic ATP is blocking the $\mathrm{K}_{\text {ATP }}$ channels.

We conclude that incubating NTS neurons in a high glucose aCSF decreases the number of low glucose-responsive neurons. Although this effect was not caused by the more depolarized membrane potential, these neurons when hyperpolarized responded more weakly to low glucose. On the other hand, the more depolarized RMPs suggest that the higher extracellular glucose can increase metabolic ATP, which blocks $\mathrm{K}_{\mathrm{ATP}}$ channels and depolarizes neuronal membrane.

\section{The depolarization induced by low glucose is not sustained for prolonged periods}

Because of the substantial effect of $\mathrm{K}_{\mathrm{ATP}}$ channels on the RMP modulation of NTS neurons, and the evidence above suggesting that the metabolic ATP can control RMP by modulating $\mathrm{K}_{\mathrm{ATP}}$ channels, we asked if in a situation of prolonged exposure to a low external glucose solution, where metabolic ATP can be reduced, the membrane depolarization could be sustained.

For this purpose, we recorded the membrane potential after perfusion of $0.5 \mathrm{mM}$ glucose for longer than the 10 -min period we used in the previous recordings $(n=4)$. We observed in three neurons that the depolarization caused by perfusion with $0.5 \mathrm{mM}$ glucose starts to reverse after around $1033 \pm 101$ s. In two of these neurons, we applied tolbutamide, which depolarized the RMP to values similar to values at the beginning of low glucose aCSF perfusion (Fig. 11Aa and $b$ ). Interestingly, in one non-responsive neuron, the RMP hyperpolarized after $1300 \mathrm{~s}$ of exposure to $0.5 \mathrm{mM}$ glucose, and the addition of tolbutamide reversed the hyperpolarization (Fig. 11B), suggesting that this hyperpolarization was at least partially caused by the opening of $\mathrm{K}_{\mathrm{ATP}}$ channels. To investigate this further, we applied tolbutamide during the low glucose-induced depolarization $(n=3)$. In these three neurons, tolbutamide blocked the hyperpolarization caused by prolonged low glucose exposure (Fig. 11 Ca and $b$ ). We conclude that the effect of low external glucose in depolarizing the membrane of NTS neurons is short lived and is probably reversed by depletion of intracellular ATP and opening of $\mathrm{K}_{\mathrm{ATP}}$ channels.

\section{Discussion}

Glucose is the primary energy source for brain metabolism and survival (Mergenthaler et al. 2013). Due to high levels of energy expenditure for neuronal activity and low content of brain glycogen, the human brain consumes up to $20 \%$ of the glucose-derived energy under physiological conditions (Magistretti \& Allaman, 2015). Brain hypoglycaemia, a condition of limited energy availability, can cause neuronal death and may lead to cognitive impairments and loss of consciousness (Cryer, 2007). Therefore, several peripheral and central components act on energy homeostasis regulation to maintain adequate levels of circulating glucose (Marty et al. 2007; Verberne et al. 2014).
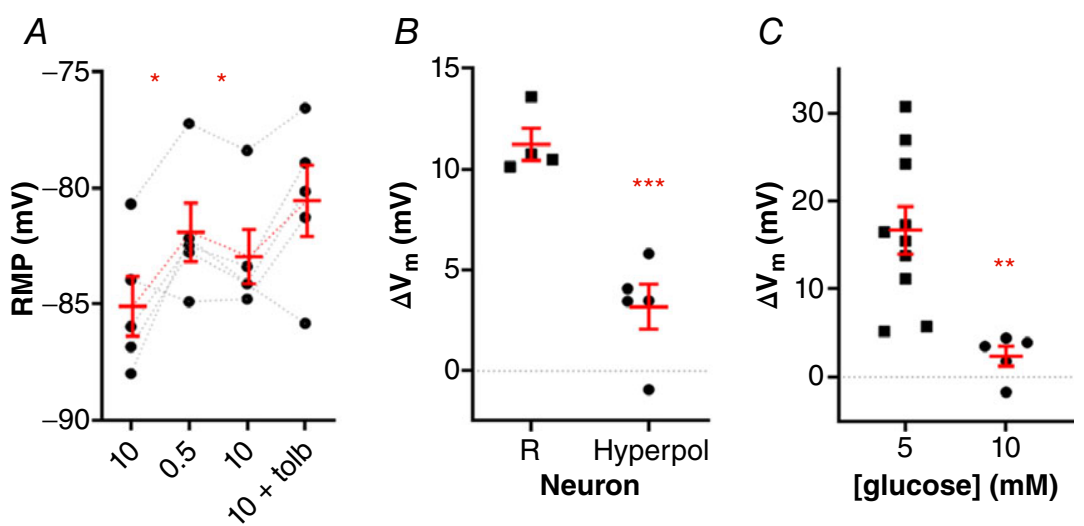

[glucose] (mM)

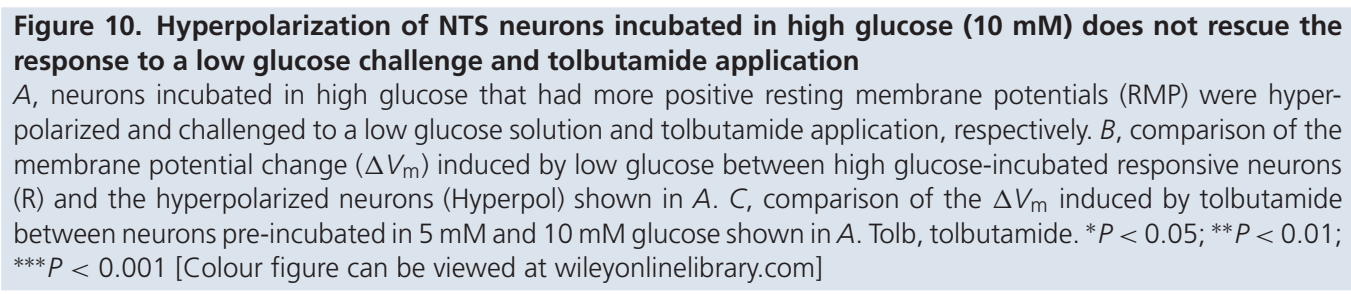



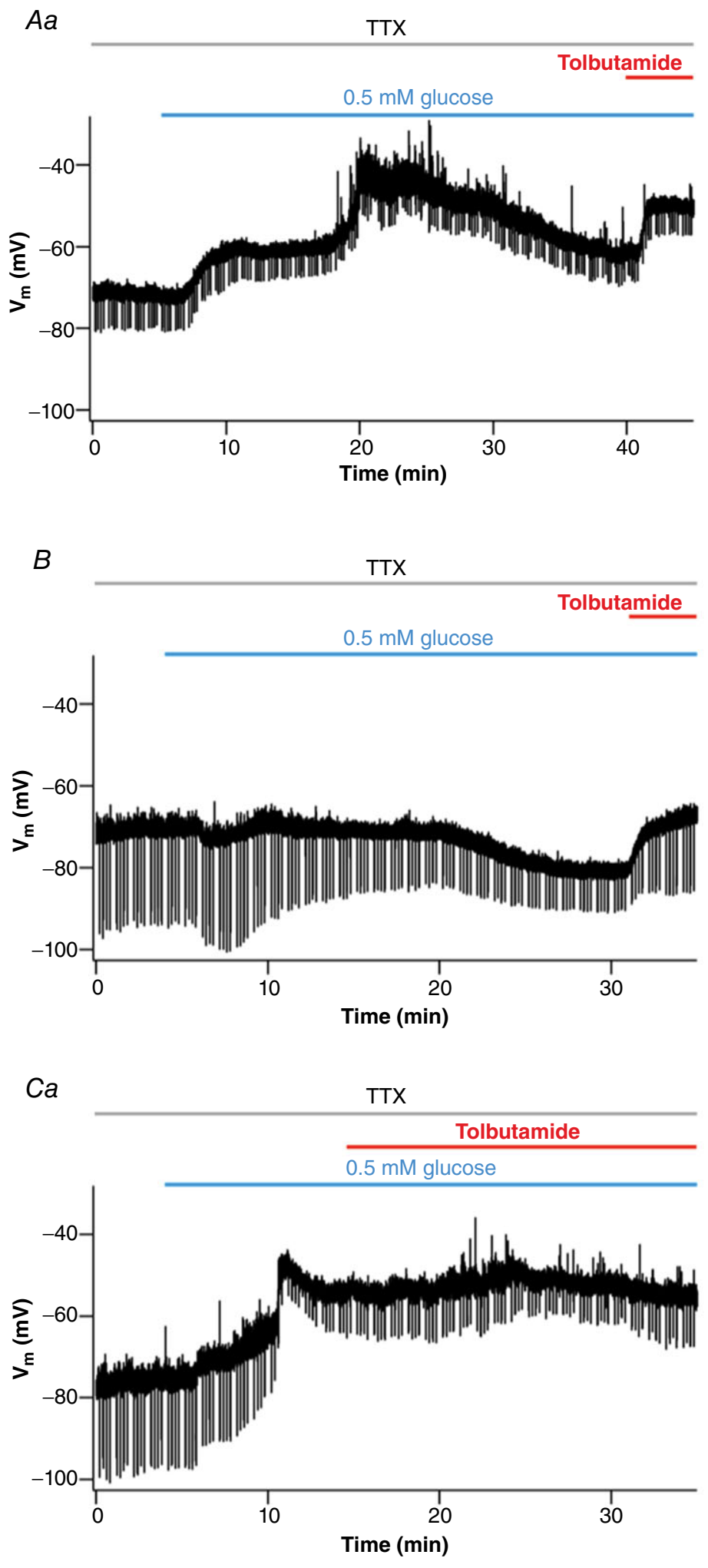

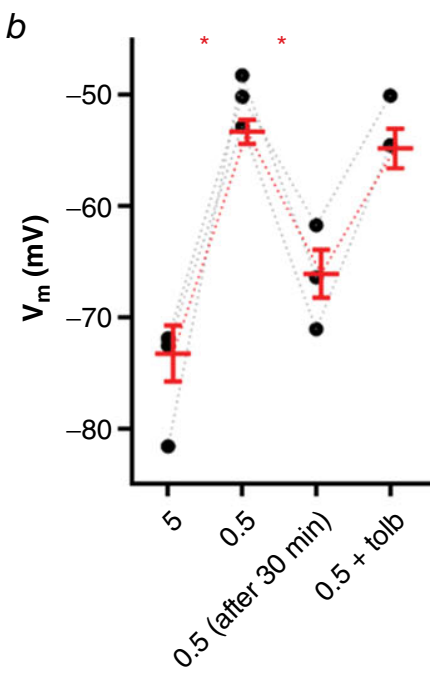

[glucose] ( $\mathrm{mM})$

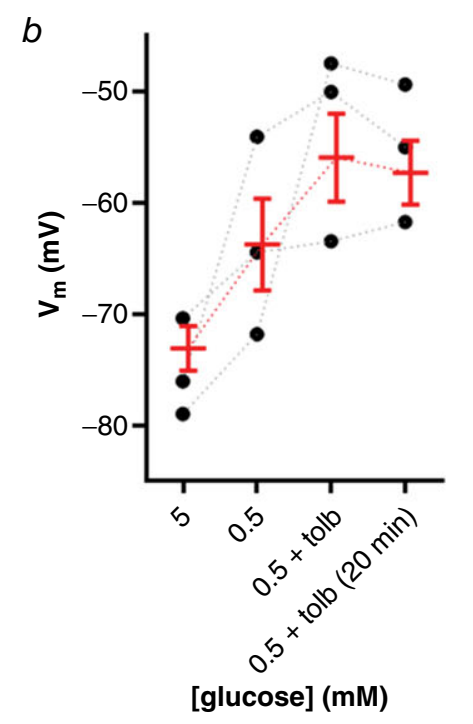

Figure 11. Low glucose-induced depolarization of NTS neurons is short living and reversed by the opening of $\mathrm{K}_{\text {ATP }}$ channels

$A$, subset of neurons initially responsive to low glucose is hyperpolarized after a long period of exposure, as shown by a representative recording $(\mathrm{Aa}$ ). Note that tolbutamide reverses the hyperpolarizing effect induced by low 
Recent studies have demonstrated that glucose-sensing neurons located in the brainstem NTS can sense glucose levels in the extracellular milieu, using mechanisms which could involve $\mathrm{K}_{\mathrm{ATP}}$ channels (Balfour et al. 2006; Lamy et al. 2014; Boychuk et al. 2015; Halmos et al. 2015; Roberts et al. 2017). Here we found that NTS neurons express $\mathrm{K}_{\mathrm{ATP}}$ channels, as they all responded to diazoxide. In $5 \mathrm{mM}$ external glucose, most of these channels are open, since they depolarized in response to tolbutamide. Thus, in normoglycaemic conditions, NTS neurons have open $\mathrm{K}_{\mathrm{ATP}}$ channels, which could be modulated by local metabolism. In fact, when we incubated the slices in $10 \mathrm{mM}$ glucose, the neurons were more depolarized and unresponsive (or much less responsive) to tolbutamide. These data show that NTS neurons can modulate their membrane potential using $\mathrm{K}_{\mathrm{ATP}}$ channels.

Our experiments were performed in whole-cell patch clamp using $4 \mathrm{mM} \mathrm{Mg-ATP}$ in the internal solution. Balfour et al. (2006) showed that NTS neurons are more responsive to metabolic ATP than the ATP provided by the electrode solution. Similar results were described in DMX neurons (Müller et al. 2002), and hypothalamic neurons (Song et al. 2001). Although not yet elucidated, this effect is probably due to the compartimentalization of $\mathrm{K}_{\mathrm{ATP}}$ channels in specific membrane domains (Garg et al.2009) closer to mitochondria and glycolytic enzymes, which have been shown to be concentrated in regions of high metabolic demand and glucose transport activity (Zecchin et al. 2015, Agrawal et al. 2018). Interestingly, this concentration of ATP is more than the micromolar concentrations needed to block Kir6.2/SUR1 channels (Baukrowitz et al. 1998), which is a subunit composition present in NTS neurons (Karschin et al. 1997; Balfour et al. 2006; Halmos et al. 2015). However, the effect of tolbutamide shows that there are $\mathrm{K}_{\mathrm{ATP}}$ channels open even with $4 \mathrm{mM}$ internal ATP. This can be explained by the sensitivity of $\mathrm{K}_{\mathrm{ATP}}$ channels to the ADP/ATP ratio, because they are activated by Mg-ADP (Nichols et al. 1996; Shyng et al. 1997) and their affinity to ATP is greatly reduced by phosphatidylinositol 4,5-bis-phosphate $\left(\mathrm{PIP}_{2}\right.$; Baukrowitz et al. 1998; Shyng et al. 2000). Thus, our whole-cell recordings very likely reflect the physiological responses of NTS neurons to metabolic ATP derived from external glucose.

In the current investigation, we showed that low glucose $(0.5 \mathrm{mM})$ induces a voltage-dependent depolarization in most NTS neurons of rats. These effects were not observed when the internal electrode solution contained
$3 \mathrm{mM}$ glucose, showing that the neuron itself is sufficient to detect and respond to a drop in external glucose concentration, although some influence by glial cells cannot be discarded, as suggested by McDougal et al. (2013). Additionally, we showed that the RMP in NTS neurons incubated in $10 \mathrm{mM}$ glucose aCSF is more depolarized and less sensitive to tolbutamide, even when hyperpolarized, suggesting they are depolarized by blocking of $\mathrm{K}_{\mathrm{ATP}}$ channels by metabolic ATP. Therefore, we expected that the depolarization of the RMP induced by the incubation of slices in high glucose could lead to an increase in the number of neurons unresponsive to a low glucose challenge, since our findings demonstrated a voltage-dependent depolarization by low glucose (i.e. the more negative the RMP, the bigger the membrane potential response amplitude), which was indeed observed. Neurons unresponsive to low glucose accounted for 35\% when incubated in normal aCSF, but $\sim 70 \%$ when incubated in high glucose aCSF. Interestingly, these neurons were able to respond to low glucose when hyperpolarized, but the magnitude of the response was significantly smaller, suggesting that other mechanisms are affecting the responsiveness of these neurons to low external glucose.

We also observed that the fraction of low glucoseand tolbutamide-responsive neurons was decreased in slices from 11-week-old animals in comparison to slices from 3- or 6-week-old animals. These neurons were also more depolarized than responsive neurons, as observed in slices from younger animals. Because the low glucoseor tolbutamide-induced depolarizations in responsive neurons from 11- and 3-week-old animals were similar, we believe the reason for this difference is the presence of more depolarized neurons in 11-week-old animals. We don't know the reason for this difference in RMP, which could be related or not to developmental changes. Importantly, 3-week-old rats are in the weaning period with (access to the caloric maternal milk) while 11-week-old rats are young adult animals feeding on the standard lab rat chow. The differences in caloric intake, type of meals, and food-related behaviour could lead to distinct metabolic states, and thus changes in passive electrophysiological properties of NTS neurons. Nevertheless, further investigations are needed to elucidate these questions.

Interestingly, Balfour et al. (2006) reported that $\sim 80 \%$ of NTS/DMX neurons of 3- to 4-week-old rats were unresponsive to glucose removal. However, these authors performed electrophysiological recordings using a control 
aCSF with $10 \mathrm{mM}$ glucose. They also showed the expression of the $\mathrm{K}_{\mathrm{ATP}}$ channel subunit SUR1 in cells that did not respond to low glucose, which suggests that in these neurons $\mathrm{K}_{\mathrm{ATP}}$ channels are present but could be saturated by high glucose-derived ATP levels.

Low extracellular glucose induces $\mathrm{K}_{\mathrm{ATP}}$ channels to open following a decrease in intracellular ATP levels (Hibino et al. 2010), but we observed a hyperpolarization response to low glucose in only two of 60 NTS neurons incubated in $5 \mathrm{mM}$ glucose aCSF. Other groups have reported that sensitivity to glucose is not observed in all NTS neurons expressing $\mathrm{K}_{\text {ATP }}$ channel subunits (Dallaporta et al. 2000; Balfour et al. 2006). Lamy et al. (2014) reported an increase in $R_{\text {input }}$ with the closure of leak potassium channels in GLUT2-expressing GABAergic neurons activated by low glucose in mice. This could account for the response we observed, but again, the low glucose-sensitive current observed in this report was a linear non-rectifying current, which is not compatible with the voltage dependency we observed, and we observed mainly a decrease in $R_{\text {input }}$, suggesting the opening of an inward conductance. Additionally, our findings demonstrate that most NTS neurons exhibit a voltage-dependent depolarization and a decrease in $R_{\text {input }}$ in response to a low glucose solution, which is suggestive of the opening of a cationic conductance. We found that low glucose induces an inward cationic current with a reversal around $-60 \mathrm{mV}$, which could explain the voltage dependence of the depolarization induced by low glucose.

Interestingly, Balfour \& Trapp (2007) showed the opening of an inwardly rectifying current in some neurons of the NTS in response to glucose removal, what could contribute to the depolarizing response seen in our recordings. The opening of $\mathrm{HCN}$ channels, which mediate the inwardly rectifying cationic $h$ current, could explain our results, but the activation of the low glucose-induced current was very fast, not compatible with the slow activation of the HCN channels. Additionally, we performed experiments using the antagonist of these channels, ZD7288 $(10 \mu \mathrm{M})$, but the results were inconclusive because this drug produced a progressive depolarization of the membrane, masking any effect of low glucose (not shown). In the ventromedial hypothalamus, low glucose led to the closure of chloride channels and membrane depolarization in some neurons (Routh et al. 2014), but the reversal potential of the low glucose-induced current observed in the current investigation does not suggest a chloride conductance. Ionic mechanisms other than ion channels can contribute to depolarize neurons under low glucose availability. The electrogenic $\mathrm{Na}^{+} / \mathrm{K}^{+}$pumps are important generators of electrochemical gradients in cells. High glucose levels stimulate the $\mathrm{Na}^{+} / \mathrm{K}^{+}$-ATPase pump and trigger membrane hyperpolarization in glucose-excited neurons in the lateral hypothalamus (Oomura et al. 1974), and brain hypoglycaemia reduces the activity of the $\mathrm{Na}^{+} / \mathrm{K}^{+}$-ATPase pump (Lees, 1991) and may lead to depolarization of neurons (Balfour \& Trapp, 2007). However, this mechanism is not compatible with the voltage dependency and the decrease in the $R_{\text {input }}$ we observed. Nevertheless, the reduction of the activity of the $\mathrm{Na}^{+} / \mathrm{K}^{+}$-ATPase pump could constitute an additional component altering the RMP of NTS neurons in response to reduced external glucose concentration.

Since $\mathrm{K}_{\mathrm{ATP}}$ blockage and low glucose both produce membrane depolarization, but low glucose is ineffective at depolarizing neurons when the $\mathrm{K}_{\text {ATP }}$ channels are entirely blocked, we believe that the depolarization induced by low external glucose might represent a form of homeostatic regulation of the RMP in order to avoid an excessive hyperpolarization by unblocking $\mathrm{K}_{\mathrm{ATP}}$ channels during a hypoglycaemia episode, which could be essential for the efficient performance of the vital autonomic functions controlled by the NTS. However, when we left the neurons for more than $10-20 \mathrm{~min}$ in low external glucose, we started to observe a hyperpolarization that was prevented by tolbutamide. These results show that the low glucose-induced depolarization does not last for prolonged periods, and the membrane starts to hyperpolarize in response to the decreased metabolic ATP.

Our results clearly show a mechanism of membrane depolarization driven by a rapid reduction in external glucose that could be potentially relevant for neurometabolic responses to hypoglycaemia. However, when neurons are maintained in a hyperglycaemic solution (similar to high post-prandial circulating glucose levels and diabetic conditions), the number of NTS neurons responsive to low glucose decreases, and the latency for peak response increases. Because NTS neurons are involved in the counter-regulatory mechanisms in response to hypoglycaemia, which include a decrease in pancreatic insulin secretion, an increase in pancreatic glucagon secretion, and an increase in adrenomedullary adrenaline (epinephrine) secretion (Cryer, 2005), the detection of a rapid drop in glycaemia by these neurons in prolonged hyperglycaemic situations might be blunted. Sudden drops in glycaemia are common occurrences in patients with type 1 and advanced type II diabetes, caused by insulin interventions to control glycaemia (Mergenthaler et al. 2013). In these patients, a failed counter-regulatory response to hypoglycaemia is commonly observed, a condition named hypoglycaemia-associated autonomic failure (Cryer, 2005). Interestingly, glucose-sensing neurons in the ventromedial hypothalamus decrease their response to low glucose after repetitive injections of insulin (Song \& Routh, 2006). Our data suggest that the establishment of more depolarized RMPs of NTS neurons by the closure of $\mathrm{K}_{\mathrm{ATP}}$ channels due to increased intracellular ATP levels could be an additional mechanism contributing to 
reduced brain sensitivity to a low glucose challenge during hyperglycaemic conditions. More studies are needed to support this interesting hypothesis.

\section{References}

Agrawal A, Pekkurnaz G \& Koslover EF (2018). Spatial control of neuronal metabolism through glucose-mediated mitochondrial transport regulation. Elife 18, 7.

Accorsi-Mendonça D, Castania JA, Bonagamba LG, Machado BH \& Leão RM (2011). Synaptic profile of nucleus tractus solitarius neurons involved with the peripheral chemoreflex pathways. Neuroscience 197, 107-120.

Andrew, SF, Dinh, TT \& Ritter, S (2007). Localized glucoprivation of hindbrain sites elicits corticosterone and glucagon secretion. Am J Physiol Regul Integr Comp Physiol 292, R1792-R1798.

Ashcroft FM \& Rorsman P (2013). $\mathrm{K}_{\text {ATP }}$ channels and islet hormone secretion: new insights and controversies. Nat Rev Endocrinol 9, 660-669.

Balfour RH, Hansen AM \& Trapp S (2006). Neuronal responses to transient hypoglycaemia in the dorsal vagal complex of the rat brainstem. J Physiol 570, 469-484.

Balfour RH \& Trapp S (2007). Ionic currents underlying the response of rat dorsal vagal neurones to hypoglycaemia and chemical anoxia. J Physiol 579, 691-702.

Bohland M, Matveyenko AV, Saberi M, Khan AM, Watts AG \& Donovan CM (2014). Activation of hindbrain neurons is mediated by portal-mesenteric vein glucosensors during slow-onset hypoglycemia. Diabetes 63, 2866-2875.

Boychuk CR, Gyarmati P, Xu H \& Smith BN (2015). Glucose sensing by GABAergic neurons in the mouse nucleus tractus solitarii. J Neurophysiol 114, 999-1007.

Baukrowitz T, Schulte U, Oliver D, Herlitze S, Krauter T, Tucker SJ, Ruppersberg JP \& Fakler B (1998). PIP 2 and PIP as determinants for ATP inhibition of $\mathrm{K}_{\mathrm{ATP}}$ channels. Science 282, 1141-1144.

Cryer PE (2005). Mechanisms of hypoglycemia-associated autonomic failure and its component syndromes in diabetes. Diabetes 54, 3592-3601.

Cryer PE (2007). Hypoglycemia, functional brain failure, and brain death. J Clin Invest 117, 868-870.

Dallaporta M, Perrin J \& Orsini JC (2000). Involvement of adenosine triphosphate-sensitive $\mathrm{K}^{+}$channels in glucosesensing in the rat solitary tract nucleus. Neurosci Lett 278, $77-80$.

Donovan CM \& Watts AG (2014). Peripheral and central glucose sensing in hypoglycemic detection. Physiology (Bethesda) 29, 314-324.

Gao L, Ortega-Sáenz P, García-Fernández M, GonzálezRodríguez P, Caballero-Eraso C \& López-Barneo J (2014). Glucose sensing by carotid body glomus cells: potential implications in disease. Front Physiol 5, 398.

Garg V, Jiao J \& Hu K (2009). Regulation of ATP-sensitive $\mathrm{K}^{+}$ channels by caveolin-enriched microdomains in cardiac myocytes. Cardiovasc Res. 82, 51-58.

Gross PM, Wall KM, Pang JJ, Shaver SW \& Wainman DS (1990). Microvascular specializations promoting rapid interstitial solute dispersion in nucleus tractus solitarius. Am J Physiol Regul Integr Comp Physiol 259, R1131-R1138
Halmos KC, Gyarmati P, Xu H, Maimaiti S, Jancsó G, Benedek G \& Smith BN (2015). Molecular and functional changes in glucokinase expression in the brainstem dorsal vagal complex in a murine model of type 1 diabetes. Neuroscience 306, 115-122.

Hermann GE, Viard E \& Rogers RC (2014). Hindbrain glucoprivation effects on gastric vagal reflex circuits and gastric motility in the rat are suppressed by the astrocyte inhibitor fluorocitrate. J Neurosci 34, 10488-10496.

Hibino H, Inanobe A, Furutani K, Murakami S, Findlay I \& Kurachi Y (2010). Inwardly rectifying potassium channels: their structure, function, and physiological roles. Physiol Rev 90, 291-366.

Karschin C, Ecke C, Ashcroft FM \& Karschin A (1997). Overlapping distribution of $\mathrm{K}_{\text {ATP }}$ channel-forming Kir6.2 subunit and the sulfonylurea receptor SUR1 in rodent brain. FEBS Lett 401, 59-64.

Lam CK, Chari M, Su BB, Cheung GW, Kokorovic A, Yang CS, Wang PY, Lai TY \& Lam TK (2010). Activation of $\mathrm{N}$-methyl-D-aspartate (NMDA) receptors in the dorsal vagal complex lowers glucose production. J Biol Chem $\mathbf{2 8 5}$, 21913-21921.

Lamy CM, Sanno H, Labouèbe G, Picard A, Magnan C, Chatton JY \& Thorens B (2014). Hypoglycemia-activated GLUT2 neurons of the nucleus tractus solitarius stimulate vagal activity and glucagon secretion. Cell Metab 19, 527-538.

Lees GJ (1991). Inhibition of sodium-potassium-ATPase: a potentially ubiquitous mechanism contributing to central nervous system neuropathology. Brain Res Brain Res Rev 16, 283-300.

McDougal DH, Hermann GE \& Rogers RC (2013). Astrocytes in the nucleus of the solitary tract are activated by low glucose or glucoprivation: evidence for glial involvement in glucose homeostasis. Front Neurosci 7, 249.

Magistretti PJ \& Allaman I (2015). A cellular perspective on brain energy metabolism and functional imaging. Neuron 86, 883-901.

Marty N, Dallaporta M \& Thorens B (2007). Brain glucose sensing, counterregulation, and energy homeostasis. Physiology (Bethesda) 22, 241-251.

Mergenthaler P, Lindauer U, Dienel GA \& Meisel A (2013). Sugar for the brain: the role of glucose in physiological and pathological brain function. Trends Neurosci 36, 587-597.

Mimee A \& Ferguson AV (2015). Glycemic state regulates melanocortin, but not nesfatin-1, responsiveness of glucose-sensing neurons in the nucleus of the solitary tract. Am J Physiol Regul Integr Comp Physiol 308, R690-R699.

Müller M, Brockhaus J \& Ballanyi K (2002). ATP-independent anoxic activation of ATP-sensitive $\mathrm{K}^{+}$channels in dorsal vagal neurons of juvenile mice in situ. Neuroscience 109, 313-328.

Nichols CG (2006). $K_{\text {ATP }}$ channels as molecular sensors of cellular metabolism. Nature 440, 470-476.

Nichols CG, Shyng S-L, Nestorowicz A, Glaser B, Clement J IV, Gonzalez G, Aguilar-Bryan L, Permutt AM \& Bryan JP (1996). Adenosine diphosphate as an intracellular regulator of insulin secretion. Science 272, 1785-1787. 
Oomura Y, Ooyama H, Sugimori M, Nakamura T \& Yamada Y (1974). Glucose inhibition of the glucose-sensitive neurone in the rat lateral hypothalamus. Nature 247, 284-286.

Ritter S, Dinh TT \& Zhang Y (2000). Localization of hindbrain glucoreceptive sites controlling food intake and blood glucose. Brain Res 856, 37-47.

Roberts BL, Zhu M, Zhao H, Dillon C \& Appleyard SM (2017). High glucose increases action potential firing of catecholamine neurons in the nucleus of the solitary tract by increasing spontaneous glutamate inputs. Am J Physiol Regul Integr Comp Physiol 313, R229-R239.

Routh VH, Hao L, Santiago AM, Sheng Z \& Zhou C (2014). Hypothalamic glucose sensing: making ends meet. Front Syst Neurosci 8, 236.

Seaquist ER, Damberg GS, Tkac I \& Gruetter R (2001). The effect of insulin on in vivo cerebral glucose concentrations and rates of glucose transport/metabolism in humans. Diabetes 50, 2203-2209

Shyng S, Ferrigni T \& Nichols CG (1997). Regulation of $\mathrm{K}_{\text {ATP }}$ channel activity by diazoxide and MgADP. Distinct functions of the two nucleotide binding folds of the sulfonylurea receptor. J Gen Physiol 110, 643-654.

Shyng SL, Barbieri A, Gumusboga A, Cukras C, Pike L, Davis JN, Stahl PD \& Nichols CG (2000). Modulation of nucleotide sensitivity of ATP-sensitive potassium channels by phosphatidylinositol-4-phosphate 5-kinase. Proc Natl Acad Sci U S A 97, 937-941.

Song Z, Levin BE, McArdle JJ, Bakhos N \& Routh VH (2001). Convergence of pre- and postsynaptic influences on glucosensing neurons in the ventromedial hypothalamic nucleus. Diabetes 50, 2673-2681.

Song Z \& Routh VH (2006). Recurrent hypoglycemia reduces the glucose sensitivity of glucose-inhibited neurons in the ventromedial hypothalamus nucleus. Am J Physiol Regul Integr Comp Physiol 291, R1283-R1287.

Thorens B (2012). Sensing of glucose in the brain. Handb Exp Pharmacol, 277-294.

Verberne AJ, Sabetghadam A \& Korim WS (2014). Neural pathways that control the glucose counterregulatory response. Front Neurosci 8, 38.
Zecchin A, Stapor PC, Goveia J \& Carmeliet P (2015). Metabolic pathway compartmentalization: an underappreciated opportunity? Curr Opin Biotechnol 34, 73-81.

Zhao S, Kanoski SE, Yan J, Grill HJ \& Hayes MR (2012). Hindbrain leptin and glucagon-like-peptide-1 receptor signaling interact to suppress food intake in an additive manner. Int J Obes (Lond) 36, 1522-1528.

\section{Additional information}

\section{Competing interests}

None declared

\section{Author contributions}

CBM and RML designed the experiments. CBM performed the experiments and analyzed the data. CBM and RML interpreted the data, wrote and revised the manuscript. Both authors have approved the final version of the manuscript and agree to be accountable for all aspects of the work. All persons designated as authors qualify for authorship, and all those who qualify for authorship are listed

\section{Funding}

Research supported by FAPESP grant (2016/01607-4). C.B.M. is a CNPq PhD scholarship recipient. R.M.L. is a CNPq research fellow.

\section{Acknowledgments}

We thank Mr J. Fernando Aguiar and Dr André L. A. Dagostin for technical support, and Drs Daniela Accorsi-Mendonça, Luiz C. Navegantes and Luiz G. Branco for their criticisms and suggestions. 


\section{ANEXO B}

Artigo publicado não-relacionado à tese 
REVIEW ARTICLE

\title{
Mechanism of Action of Novel Glibenclamide Derivatives on Potassium and Calcium Channels for Insulin Secretion
}

\author{
Marisa Jádna Silva Frederico ${ }^{1}$, Allisson Jhonatan Gomes Castro ${ }^{1}$, Danusa Menegaz ${ }^{1,3}$, \\ Cahuê De Bernardis Murat ${ }^{1}$, Camila Pires Mendes ${ }^{1}$, Alessandra Mascarello ${ }^{2}$, Ricardo José Nunes ${ }^{2}$ \\ and Fátima Regina Mena Barreto Silva, ${ }^{1,3, *}$
}

\begin{abstract}
${ }^{1}$ Universidade Federal de Santa Catarina, Departamento de Bioquímica, Centro de Ciências Biológicas, Campus Universitário, Bairro Trindade, Cx. Postal 5069, CEP: 88040-970, Florianópolis, SC, Brazil, ${ }^{2}$ Universidade Federal de Santa Catarina, Departamento de Química, Centro de Ciências Físicas e Matemáticas, Campus Universitário, Bairro Trindade, CEP: 88040-900, Florianópolis, SC, Brazil; ${ }^{3}$ Núcleo de Bioeletricidade Celular (NUBIOCEL) - Centro de Ciências Biológicas, Universidade Federal de Santa Catarina, Campus Universitário, Trindade, Cx. Postal 5069, CEP: 88040-970 - Florianópolis, SC, Brazil
\end{abstract}

\begin{abstract}
Glibenclamide is widely used and remains a cornerstone and an effective antihyperglycemic drug. After the casual discovery of its hypoglycemic potential, this compound was introduced for diabetes treatment. However, the long-term side effects reveal that glibenclamide should be replaced by new molecules able to maintain the health of $\beta$-cells, protecting them from hyperstimulation/hyperexcitability, hyperinsulinemia, functional failure and cell death. The aim of this review was to highlight the main mechanism of action of glibenclamide and the influence of its derivatives, such as acylhydrazones, sulfonamides and sulfonylthioureas on $\beta$-cells potassium and calcium channels for insulin secretion as well as the contribution of these new compounds to restore glucose homeostasis. Furthermore, the role of glibenclamide-based novel structures that promise less excitability of $\beta$-cell in a long-term treatment with effectiveness and safety for diabetes therapy was discussed.
\end{abstract}

Keywords: Acyl-hydrazones, glibenclamide derivatives, glucose homeostasis, insulin, pancreatic $\beta$-cell, sulfonamides, sulfonylthioureas, sulfonylureas.

\section{GENERAL ASPECTS}

In mammals, the maintenance of glucose levels is regulated by a complex network of communication mainly established between the intestines, blood, liver, pancreas, skeletal muscle, adipose tissue and kidney, in an action coordinated by hormones and the central nervous system [1-5]. The glycaemia is tightly regulated in a very narrow range of glucose although a substantial shift in glucose flux occurs between the fasting to the fed state and vice-versa [6,7]. The glucose homeostasis is needed due to the intervals of food intake and fasting periods that are widely variable. Thus, the control of glycaemia is maintained by insulin, glucagon-like polypeptide-1, free fatty acids, parasympathetic inputs, amino acids, glucose-induced metabolic amplifying factors and counterregulatory hormones, such as adrenaline, growth factors and corticosteroids $[4,8]$.

\footnotetext{
*Address correspondence to this author at the Departamento de Bioquímica, Centro de Ciências Biológicas, UFSC. Campus Universitário, Bairro Trindade, Cx Postal 5069, CEP: 88040-970 - Florianópolis, Santa Catarina, Brazil; Tel: +55 48 3721-6912; Fax: +55 48 3721-9672;

E-mail: mena.barreto@ufsc.br
}

The hallmarks of diabetes mellitus are hyperglycemia and glucose intolerance caused by insulin deficiency and/or impaired effectiveness of insulin action. This disorder has traditionally been named as type 1 diabetes (T1D; autoimmune destruction of $\beta$-cells) and type 2 diabetes (T2D; insulin resistance and hyperglycemia that lead to metabolic syndrome $[9,10])$. In addition, there is another type of diabetes, Maturity-onset diabetes of the young (MODY) characterized by etiology. MODY is a group of different forms of type 2 diabetes that can be treated with sulfonylureas (MODY 3). It is a monogenic disease with autosomal dominant inheritance that usually develops in childhood, adolescence or youth and is caused by deficiency of insulin secretion $[11,12]$.

Insulin is the hormone primarily responsible for stimulating the glucose uptake from the blood stream into systemic tissues. Whereas insulin deficiency is the result of insufficient insulin produced by the pancreas, the condition of insulin resistance occurs due to a failure of insulin receptor activation in peripheral tissues [13-16]. Accordingly, one of the strategies for the treatment of T2D is to stimulate insulin secretion from pancreatic $\beta$-cells, thereby alleviating the symptoms of diabetes without inducing $\beta$-cells exhaustion $[17,18]$. 
This was first accomplished by the class of drugs known as sulfonylureas [19], which remain as one of the most prescribed agents to the management of patients with T2D due to its high efficacy use both as monotherapy and in combination with other hypoglycemic formulas [20,21], and it is the oral antidiabetic agent present in the Model Lists of Essential Medicines of the World Health Organization [22]. It is worthwhile to mention that besides the class of sulfonylureas, other five classes of oral antidiabetic drugs are available for diabetes therapy: biguanides, meglitinides, thiazolidinediones, dipeptidyl peptidase IV inhibitors and $\alpha-$ glucosidase inhibitors [23-25].

This review focuses on sulfonylureas and highlights the mechanism of action of glucose, glibenclamide and novel derivatives on coupled/uncoupled metabolo-electrical events by potassium and calcium channels in $\beta$-cells for insulin secretion. Therefore, the comparison of signal transduction and insulinogenic index between glucose, glibenclamide and its derivatives in relation to the reduction of side effects coupled with effectiveness and safety for diabetes therapy were discussed.

\section{GLIBENCLAMIDE ANALOGUES/DERIVATIVES AS A NEW THERAPEUTIC PROMISE}

The sulfonylureas are traditionally divided into two groups or generations of agents [26], differing by substitutions in the benzene ring position and in residue of urea nitrogen molecule. The first group of sulfonylureas includes tolbutamide, chlorpropamide, acetohexamide and tolazamide. In the second generation, glibenclamide or glyburide, glipizide and gliclazide are the compounds that exhibit about 100 -fold enhanced potential than first-generation drugs $[21,27]$. This potency seems to be due to the greater intrinsic hypoglycemic effect of the molecule rather than to a prolonged biological half-life. The most recently developed sulfonylurea is glimepiride [28].

The typical structure of the sulfonylureas derivatives inspired several research groups to synthesize new active analogues [29-34]. In this field, our group has recently published an article discussing new active molecules by direct synthesis of glibenclamide analogues (sulfonamides and sulfonylthioureas) $[35,36]$ and structurally diverse compounds, with equal or better therapeutic potential, as is the case of acylhydrazones [37] and chalcones [38-40]. Herein we select our results from the last three years (Scheme 1).

Structurally, the compounds 3-12 were intended to investigate the new features on the structure of glibenclamide (Scheme 2). The synthesis of the chemical analogues were based on bioisosterism, changing the substituint on the glibenclamide aromatic ring (3-7) and replacing the cyclohexane for benzene-substituted, as well as including thiourea instead of original urea and replacing the carbonyl group with a sulfonyl group (8-12) to verify the hypoglycemic activity.

From the benzenesulfonamide group 3-7, the most active compound 4 ( $p-\mathrm{CH}_{3}$-substituted) showed a potent insulinogenic index (Table 1) and significant stimulation on soleus muscle glycogen deposition, without exhibiting tissue toxicity. Considering the benzenesulfonylthioureas group (8-12),

the top compound 11 (thiophenyl-substituted) showed insulin secretagogue and insulinomimetic potential on glucose homeostasis.

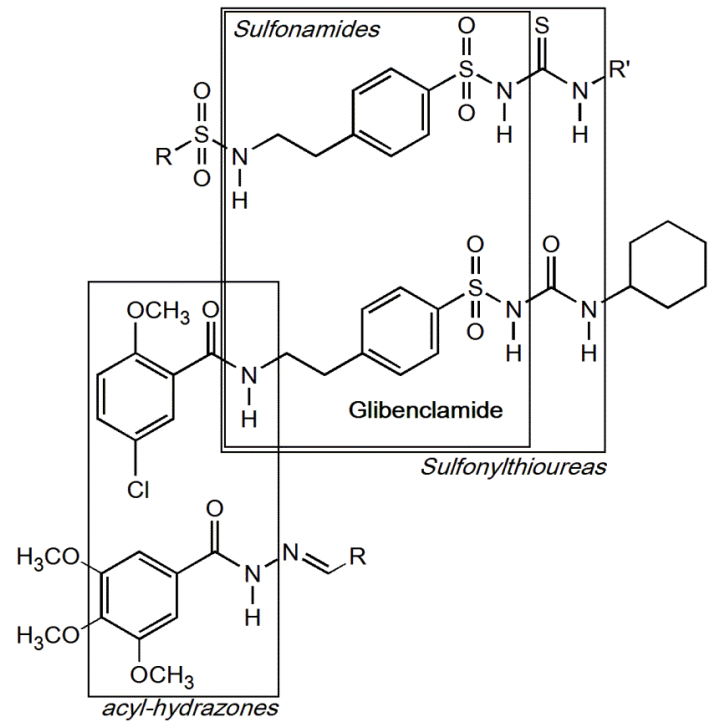

(Scheme 1). Synthetic strategy to obtain the glibenclamide analogues/derivatives.

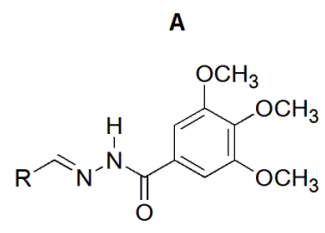

$1 \mathrm{R}=1$-naphthyl

$2 \mathrm{R}=4-\mathrm{Br}-\mathrm{phenyl}$

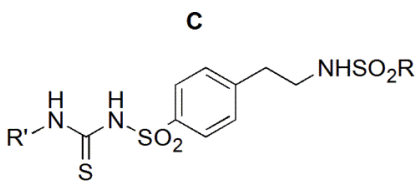

$8 \mathrm{R}=$ phenyl; $\mathrm{R}^{\prime}=$ phenyl

$9 \mathrm{R}=4-\mathrm{OCH}_{3}-$ phenyl; R' = phenyl

$10 \mathrm{R}=8$-quinoline; $\mathrm{R}^{\prime}=$ phenyl

$11 \mathrm{R}=$ thiophenyl; $\mathrm{R}^{\prime}=$ phenyl

$12 \mathrm{R}=4-\mathrm{OCH}_{3}-$ phenyl; $\mathrm{R}^{\prime}=4-\mathrm{Cl}$-phenyl

(Scheme 2). Compounds planned to investigate the new features on the structure of glibenclamide.

In regard to the structure of the acylhydrazones (1 and 2), although not closely related to glibenclamide, these compounds are excellent hypoglycemic agents and the mechanistic studies revealed a dual physiological target for the acylhydrazone 1, i.e., pancreatic islets and skeletal muscle, as a result of insulin secretagogue and insulinomimetic action. In addition, it is worthwhile to note that acylhydrazones $\mathbf{1}$ and $\mathbf{2}$ showed the highest insulinogenic index among the twelve 
compounds studied and were around 30\% higher than glibenclamide (Scheme 2 and Table 1).

Table 1. Insulinogenic index (II) of the compounds.

\begin{tabular}{|c|c|}
\hline Compound & I ( $\mathbf{n g} / \mathbf{m L})$ \\
\hline \hline $\begin{array}{c}\text { Glucose } \\
\text { Glibenclamide }\end{array}$ & 0.66 \\
1.98 \\
\hline 1 & 2.55 \\
\hline 2 & 2.53 \\
\hline 3 & 1.02 \\
\hline 4 & 1.68 \\
\hline 5 & 0.99 \\
\hline 6 & 0.50 \\
\hline 7 & 0.30 \\
\hline 8 & 0.31 \\
\hline 9 & 0.77 \\
\hline 10 & 0.84 \\
\hline 11 & 1.06 \\
\hline 12 & 0.72 \\
\hline
\end{tabular}

We recently reported that acylhydrazones $\mathbf{1}$ and $\mathbf{2}$ exhibit an antidiabetic effect due to their high insulinogenic index compared with the glucose control group ( $\mathrm{II}=0.66)$ and glibenclamide $(\mathrm{II}=1.66)$; both of them significantly reduced the serum glucose levels when compared with the hyperglycemic control group. In addition, compound $\mathbf{1}$ increased the calcium uptake in pancreatic islets and blocked ATPsensitive $\mathrm{K}^{+}\left(\mathrm{K}_{\mathrm{ATP}}\right)$. Moreover, both extracellular and stocked calcium are involved in the signal transduction of the compound to trigger insulin-containing vesicles exocytosis and hormone secretion. Compound $\mathbf{1}$ was also able to accumulate glycogen content and glucose uptake in skeletal muscle, pointing to dual physiological targets for the acylhydrazone 1 (pancreatic islets and skeletal muscle) to regulate glucose homeostasis [37].

In addition, the sulfonamide derivatives based on a glibenclamide fragment were investigated. Glycaemia and insulin secretion parameters were evaluated by in vivo treatment, whereas calcium uptake, glycogen content, intestinal disaccharidases and lactate dehydrogenase activities were performed by in vitro experiments. From those data, sulfonamide 5 reduced glucose levels and the stimulatory effect of calcium influx in pancreatic islets seems to be mediated by $\mathrm{K}_{\mathrm{ATP}}$, voltage-dependent calcium channels, calcium storage and protein kinase $\mathrm{C}$ activity to induce insulin secretion. As reported for glibenclamide, the activation of $\mathrm{PKC}$-epsilon seems to be essential for insulin exocytosis. Also, the acute effect of compound $\mathbf{5}$ contributed to glucose homeostasis by intestinal disaccharidases http://www.ncbi.nlm.nih.gov/ pubmed/24863482 inhibition and glycogen accumulation in skeletal muscle [36].
Due to several risks, the use of glibenclamide in diabetes therapy is limited and recent investigations have been carried out to discover novel and safer compounds with less side effects in relation to the induction of hyperinsulinemia and hypoglycemia. The side effects of glibenclamide in part can be explained by the activation of the transient receptor potential Ankyrin 1 (TRPA1) channel. The glibenclamide was identified as an agonist of these ionic channels. Babes et al., 2013 [41] suggested the potential participation of TRPA1 in the effect of glibenclamide as a secretagogue and a complicity in $\beta$-cell exhaustion. Continued application of glibenclamide for up to 4 days in human islets leads to decreased insulin secretion in response to an acute stimulus with sulfonylureas with reduced insulin content, down regulation of $\mathrm{K}_{\mathrm{ATP}}$ channels and increased apoptosis [42]. Furthermore, glibenclamide is known to induce oxidative stress and cell death in a dose-dependent manner in the insulinoma MIN6, exhibiting potencies higher than other anti-diabetic drugs (i.e., glimepiride, gliclazide and nateglinide) [43]. Concomitant connection with glibenclamide $\mathrm{K}_{\mathrm{ATP}}$ channels and TRPA1 channels could explain the initial exacerbation of hyperinsulinism in glibenclamide treated type 2 diabetic patients, but also the progressive deterioration of $\beta$-cell function [44].

In addition, the general side effects of glibenclamide observed in patients are around $3-5 \%$. Among these effects are gastrointestinal and hematopoietic disturbance, hypersensibility reaction and hepatic alterations. Besides that, the increased insulin can provoke weight gain [45-48].

We showed that sulfonylthiourea 11 increases insulin secretion ( $\mathrm{II}=1.06)$ in pancreatic islets and also acts as an insulinomimetic agent since it increased glucose uptake and raised GLUT4 expression and translocation in skeletal muscle [35]. In summary, both the insulinomimetic effect of the compounds mentioned above [35-37] and the insulinogenic index of the selected compounds 1, 2, 5 and 11 (Table 1) reinforce that these compounds are able to mediate insulin secretion and ameliorate the glycaemia status. Physiologically, the sulfonamide 5 and sulfonylthiourea 11 exhibit an interesting insulinogenic index compared with the glucose and glibenclamide control groups since the acute effect of these compounds stimulates insulin secretion without hyperstimulation/hyperexcitability of the $\beta$-cell (Fig. 1 and 2).

\section{GLIBENCLAMIDE AND GLUCOSE MECHANISM OF ACTION IN INSULIN SECRETION}

The $\mathrm{K}_{\mathrm{ATP}}$ channels are located in the $\beta$-cell plasma membrane where they serve as gated pores that regulate the flow of $\mathrm{K}^{+}$ions into and out of the cell. The $\mathrm{K}_{\mathrm{ATP}}$ channels are expressed ubiquitously and have diverse roles in various cells and organs $[49,50]$. In the unstimulated $\beta$-cell, the $\mathrm{K}_{\mathrm{ATP}}$ channels are open and the outward movement of $\mathrm{K}^{+}$ions through the channel keeps the membrane potential at a negative level $(-70 \mathrm{mV})$. When a rapid elevation of glucose occurs in the postabsorptive state, the increased ATP/ADP ratio leads to the closure of the $\mathrm{K}_{\mathrm{ATP}}$ channels and the depolarization of the $\beta$-cell membrane. In turn, depolarization triggers the opening of voltage-gated $\mathrm{Ca}^{2+}\left(\mathrm{Ca}_{\mathrm{v}}\right)$ channels, eliciting $\mathrm{Ca}^{2+}$ influx and an abrupt rise in intracellular $\mathrm{Ca}^{2+}\left(\left[\mathrm{Ca}^{2+}\right]_{\mathrm{i}}\right)$ stimulating the exocytosis of insulin-containing secretory granules [17, 49-52]. 


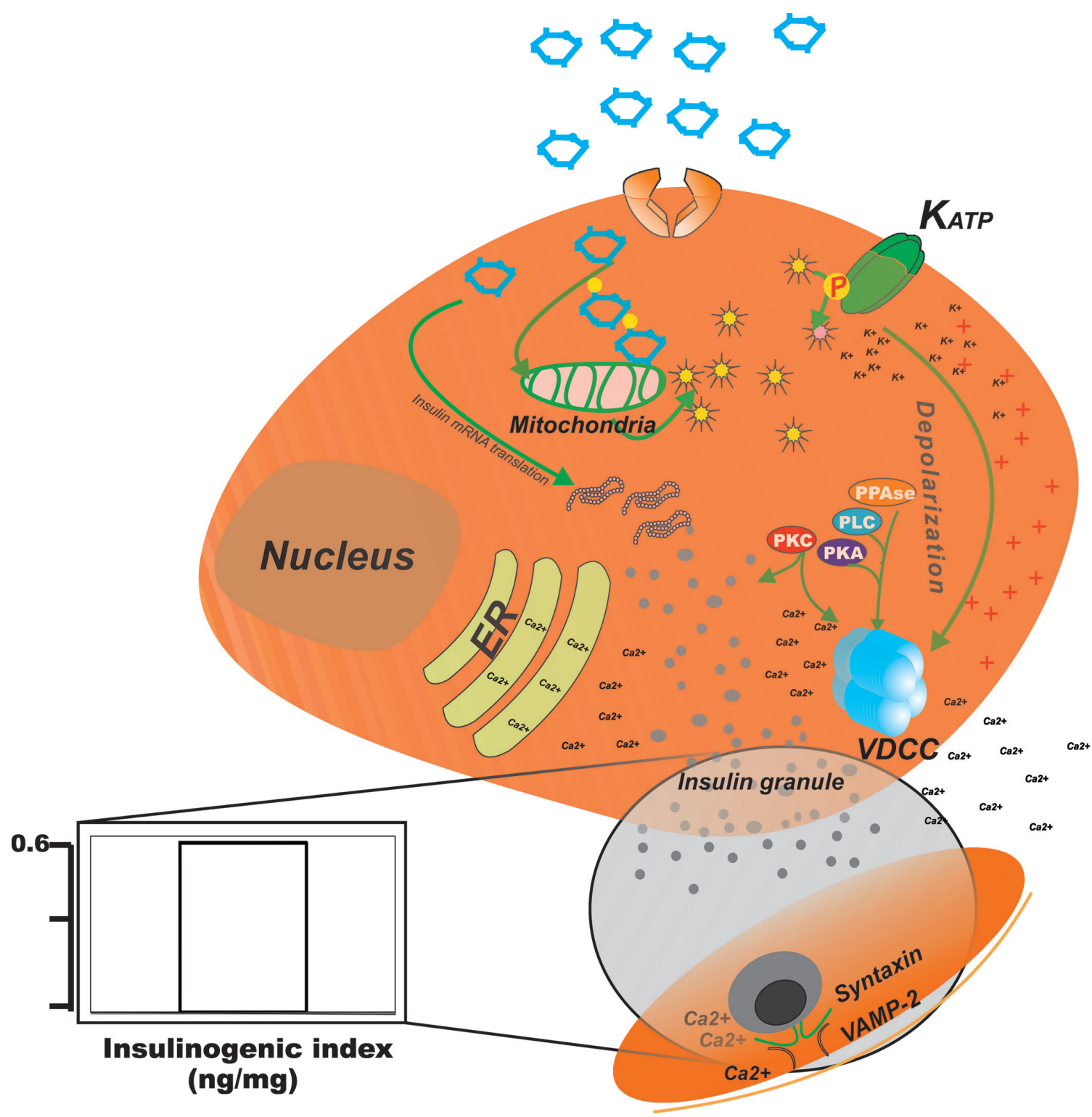

Fig. (1). A scheme illustrating the dynamics of insulin secretion in $\beta$-cell mediated by the glucose secretagogue. The increased plasma glucose level is exquisitely perceived by $\beta$-cell that takes up glucose through facilitative transport and elevates the ATP/ADP ratio. The closure of $\mathrm{K}_{\mathrm{ATP}}$ channels starts a depolarization of the plasma membrane that in turn opens the $\mathrm{Ca}_{\mathrm{v}}$ channels and triggers insulin secretion. A complex process involving inorganic components (ionic process) as well as organic constituents (protein kinases, phosphatases and exocytotic proteins) centers a molecular network of events that serve as a fine-tuning for insulin exocytosis. PKC, protein kinase C; PKA, protein kinase A; PLC, phospholiapase C; PPase, protein phosphatase.

$\mathrm{K}_{\mathrm{ATP}}$ is a heteromultimeric channel consisting of poreforming subunits Kir 6.x, which are members of the inwardly rectifying potassium channel subfamily in association with sulfonylurea receptors (SUR) subunits, which are members of the ATP-binding cassette (ABC transporter family). Two genes (KCNJ11 and KCN8) encoding the subunits Kir6 (Kir6.1 and Kir6.2) and two genes (ABCC8 and $\mathrm{ABCC} 9)$ that encode two SUR subunits (SUR1 and SUR2) [50, 53] were identified. SUR contains 17 transmembrane helices (TMs) arranged as one group of $5 \mathrm{TMs}$ and two double groups of $6 \mathrm{TMs}$ each, followed by a large cytosolic loop containing equal sequences for nucleotide binding and hydrolysis. Interaction of $\mathrm{Mg}^{2+}$ nucleotides with the nucleotidebinding domains (NBDs) mediates activation of the $\mathrm{K}_{\text {ATP }}$ channel [54-56]. The SUR subunit also endows Kir6.2 with sensitivity to certain drugs with as much inhibitory sulfonylureas as those stimulatory $\mathrm{K}^{+}$channel openers $[57,58]$.

More than one isoform exists for both Kir6.x (Kir6.1, Kir6.2) and SUR (SUR1, SUR2A, SUR2B). In most tissues, Kir6.2 serves as the pore-forming subunit, but it associates with different SUR isoforms; for example, it associates with SUR1 in the pancreas and the brain; SUR2A in the heart and skeletal muscle; and SUR2B in the brain and smooth muscle. In the vascular smooth muscle, the $\mathrm{K}_{\mathrm{ATP}}$ channel is composed of Kir6.1 in association with SUR2B. Variation in the subunit composition of the $\mathrm{K}_{\mathrm{ATP}}$ channel accounts for the different metabolic and drug sensitivities of $\mathrm{K}_{\mathrm{ATP}}$ channels in different cells. Following the cloning and proteomic of the $\mathrm{K}_{\mathrm{ATP}}$ channels subunits, it is now clear that $\mathrm{K}_{\mathrm{ATP}}$ channels in 


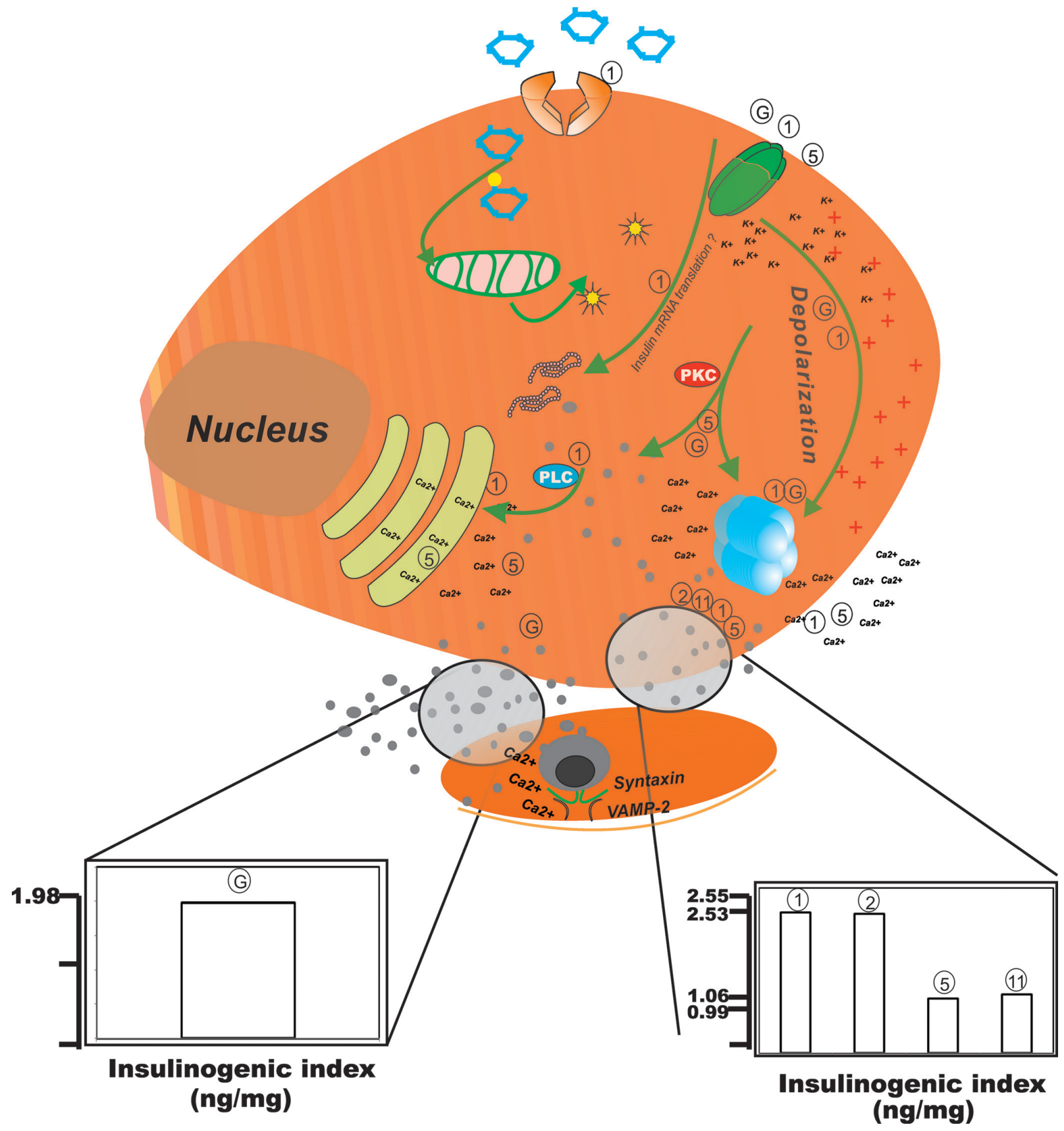

Fig. (2). A scheme illustrating the intracellular pathway of structures based on glibenclamide in insulin secretion comparing the insulinogenic index (II) of compounds with the parent glibenclamide molecule. The glibenclamide interacts with the $\mathrm{K}_{\mathrm{ATP}}$ channel, close them, and then depolarization starts. It induces the $\mathrm{Ca}_{\mathrm{v}}$ opening that abruptly increases intracellular calcium required to insulin secretion (II $=1.98$ ). The acyl-hydrazone 1 stimulates glucose uptake, increases the $\mathrm{K}_{\text {ATP }}$ channel activity and raises intracellular calcium that culminates in a high II $=$ 2.55. Sulfonamide 5 potentiates the $\mathrm{K}_{\mathrm{ATP}}$ channel activity, increases $\left[\mathrm{Ca}^{2+}\right]_{\text {i }}$ provenient by influx and storage and stimulates insulin secretion $(\mathrm{II}=0.99)$. In addition, sulfonylthiourea 11 induces insulin secretion $(\mathrm{II}=1.06)$ in $\beta$-cell. G, glibenclamide.

pancreas, brain, heart, and both skeletal and smooth muscles are encoded by different genes [24, 49, 53, 59].

Glibenclamide directly interacts with the $\mathrm{K}_{\mathrm{ATP}}$ channel to affect its closure and thereby initiates a similar chain of events coupled with the glucose-induced insulin secretion (GIIS) [24, 60]. However, glibenclamide inhibits $\mathrm{K}_{\text {ATP }}$ channel activity followed by membrane depolarization, triggering insulin secretion despite the metabolic state of the $\beta$-cell (Fig. 1 and 2).
In summary, glibenclamide directly binds on $\beta$-cells $\mathrm{K}_{\mathrm{ATP}}$ channel and closes them. Therefore, the consequence is a depolarization of the plasma membrane and $\mathrm{Ca}_{\mathrm{v}}$ channels activation [54, 61, 62]. The triggering signal (rising in $\left[\mathrm{Ca}^{2+}\right]_{\mathrm{i}}$ ) can also be produced or augmented by mechanisms that are independent of $\mathrm{K}_{\mathrm{ATP}}$ channels. Glibenclamide usually potentiates insulin secretion by a dual action: (1) moderately increasing the $\left[\mathrm{Ca}^{2+}\right]_{i}$ through complex, variable, but largely similar glucose-dependent mechanisms and; (2) producing major amplifying signals, mainly through activation 
of protein kinases, in particular PKC [63]. In addition, cAMP-regulated guanine nucleotide exchange factors (GEFs, or Epac) might mediate part of the effects of cAMP on insulin secretion, when activated by sulfonylureas [64, 65]. Activation of PKA or GEF/Epac augments the efficacy of $\mathrm{Ca}^{2+}$ on exocytosis in the $\beta$-cell. (Fig. 1) depicts the intracellular pathway trigged by high glucose to induce insulin secretion in $\beta$-cells. (Fig. 2) depicts the comparative signal transduction of glibenclamide and derivatives on $\beta$-cells to increase insulin release.

\section{THE CALCIUM CHANNEL AS BRIDGE TO INSULIN SECRETION: THE METABOLO-ELECTRICAL COU- PLING}

The $\mathrm{Ca}_{\mathrm{v}}$ channels are ubiquitously expressed in various cell types and mediate a plethora of molecular and cellular events through $\mathrm{Ca}^{2+}$ entry following depolarization elicited by an action potential $[51,66,67]$. In pancreatic $\beta$-cells, the glucose/glibenclamide stimulus for insulin secretion is only acquired due to the $\mathrm{Ca}_{\mathrm{v}}$ essential role in converting metabolic (high ATP/ADP by glycolysis) and electrical signals ( $\mathrm{K}_{\mathrm{ATP}}$ channels closing by glibenclamide) in biochemical functions. These channels are complex cell surface proteins and consist of at least four subunits: the $\mathrm{Ca}^{2+}$-conducting pore-forming transmembrane subunit $\alpha_{1}$, containing the binding sites for a variety of modulators and drugs and; the accessory subunits $\alpha_{2} \delta$ (two extracellular glycoproteins attached by disulfide linkage), $\beta$ (an $\alpha$-helice intracellular protein) and $\gamma$ (a glycoprotein with four transmembrane segments). These latter subunits are implicated in regulatory functions like channel surface expression, current amplitude, activation/inactivation kinetics and voltage dependence of gating as well as anchorage and vesicle trafficking [50, 66, 68-70].

The $\mathrm{Ca}_{\mathrm{v}}$ channels are divided into three structurally distinct subfamilies $\left(\mathrm{Ca}_{\mathrm{v}} 1, \mathrm{Ca}_{\mathrm{v}} 2\right.$ and $\left.\mathrm{Ca}_{\mathrm{v}} 3\right)$ according to their $\alpha_{1}$ subunit and, in association with certain subtypes of accessory subunits, mediate distinct types of $\mathrm{Ca}^{2+}$ currents $[66,71]$. In $\beta$-cells, seven types of $\mathrm{Ca}_{\mathrm{v}}$ channels - characterized by electrophysiological, pharmacological, biochemical and molecular properties - are described as followed: a) L-type high voltage-activated (HVA) $\mathrm{Ca}^{2+}$ channels $\left(\mathrm{Ca}_{\mathrm{v}} 1.2\right.$ and $\left.\mathrm{Ca}_{\mathrm{v}} 1.3\right)$; b) non-L-type HVA $\mathrm{Ca}^{2+}$ channels $\left[\mathrm{Ca}_{\mathrm{v}} 2.1\right.$ (P/Q-type), $\mathrm{Ca}_{\mathrm{v}} 2.2$ (N-type) and $\mathrm{Ca}_{\mathrm{v}} 2.3$ (R-type)] and; c) low voltageactivated (LVA) T-type $\mathrm{Ca}^{2+}$ channels $\left(\mathrm{Ca}_{\mathrm{v}} 3.1\right.$ and $\left.\mathrm{Ca}_{\mathrm{v}} 3.2\right)$ $[50,51,72,73]$.

The L-type $\mathrm{Ca}_{\mathrm{v}} 1$ channels are predominant in $\beta$-cells, accounting for $\sim 50 \%$ of the integrated whole-cell $\mathrm{Ca}_{\mathrm{v}}$ current in mouse and human $\beta$-cell $[74,75]$ and responsible for 60 $80 \%$ of GIIS in rodent islets and contribute in both phases of insulin secretion $[68,73]$. These large conductance channels are characterized by high sensitivity to dihydropyridine (DHP), a quick activation at membrane potentials positive to $-40 \mathrm{mV}$, and display long-lasting current and very slow inactivation $[72,75,76] . \mathrm{Ca}_{\mathrm{v}} 1$ are closely related to initiation and upstroke of the action potential due to promotion of a local increasing of $\left[\mathrm{Ca}^{2+}\right]_{\mathrm{i}}$, contributing to an optimal microenvironment for insulin-containing granules release [52, 73, 77]. In contrast, depolarization-induced granule exocytosis is not significantly affected by the L-type channel blockade [72, 74]. $\mathrm{Ca}_{\mathrm{v}} 1$ can be activated by agonist BAYK8644, and blocked by nifedipine and isradipine. Isradipine strongly inhibits insulin secretion evoked by high $(20 \mathrm{mM})$ glucose and abolishes action potential firing [52]. Our previous study showed the involvement of L-type $\mathrm{Ca}_{\mathrm{v}}$ channels on serum glucose homeostasis due to acylhydrazone 1-induced elevation of $\mathrm{Ca}^{2+}$ entry in pancreatic islets [37]. In an additional investigation, we showed that L-type $\mathrm{Ca}_{\mathrm{v}}$ channels also mediate sulfonamide 5 action in stimulating $\mathrm{Ca}^{2+}$ uptake in pancreatic islets, and might be under intracellular calcium influence and protein kinase $\mathrm{C}$ (PKC)-dependent mechanism [36]; the latter linked to rapid exocytosis induced by glibenclamide [63].

$\mathrm{Ca}_{\mathrm{v}} 1.2$ channels are well characterized and considered the prominent vehicle of $\mathrm{Ca}^{2+}$ influx in mouse $\beta$-cells. This type of channel interacts with exocytotic proteins (syntaxin $1 \mathrm{~A}$, SNAP-25 and synaptogamin), integrating the excitosome, a crucial complex that mediates vesicle fusion and exocytosis $[68,75,78-80]$. This is emphasized by the lack of mouse $\beta$-cell $\mathrm{Ca}_{\mathrm{v}} 1.2$ gene, causing abolishment of first-phase insulin secretion, decreasing $\mathrm{Ca}_{\mathrm{v}}$ currents in $\sim 45 \%$ and resulting in systemic glucose intolerance, whereas action potential firing and $\left[\mathrm{Ca}^{2+}\right]_{\mathrm{i}}$ oscillations are maintained [76].

$\mathrm{Ca}_{\mathrm{v}} 1.3$ has been associated with insulin release in humans [81], however, no differences in the $\mathrm{Ca}^{2+}$-current density were observed in $\mathrm{Ca}_{\mathrm{v}} 1.3 \mathrm{a}_{1 \mathrm{D}}$-deficient $\beta$-cells [82]. These channels are less sensitive to DHP and may contribute to lower activation threshold of action potential [51]. Novel strategies are needed to elucidate $\mathrm{Ca}_{\mathrm{v}} 1.3$ role in insulin secretion, once its knockout seems to be compensated by upregulation of the Cav1.2 gene [74, 83].

The P/Q-type $\mathrm{Ca}_{\mathrm{v}} 2.1$ channels open at the peak of the action potential $(-20$ to $0 \mathrm{mV})$ and are tightly linked to exocytosis in human $\beta$-cells. Although their antagonist $\omega$-agatoxin IVA only promotes a small decline of the action potential amplitude, it highly inhibits depolarization-evoked vesicle exocytosis $[52,72,84]$. The $\mathrm{N}$-type $\mathrm{Ca}_{\mathrm{v}} 2.2$ channels exhibit single-channel conductance and inactivation kinetics between those of the L- or T-type $\mathrm{Ca}_{\mathrm{v}}$ channels, and are blocked by $\omega$-conotoxin GVIA. Their contribution to insulin release is controversial and can be distinguished in rat $\beta$ cells, but no evidences of their presence in mice and humans are reported [51, 66, 73].

Although not at all expressed in human islets, R-type $\mathrm{Ca}_{\mathrm{v}} 2.3$ channels represent $25 \%$ of the integrated whole-cell $\mathrm{Ca}^{2+}$ current and display a fast inactivation in mouse $\beta$-cells $[52,74]$. These channels are mainly implicated in secondphase of insulin secretion and linked to slight glucose intolerance [73, 76, 85]. Pharmacological blockade of R-type $\mathrm{Ca}_{\mathrm{v}} 2.3$ channel accessed by inhibitor SNX482 caused a reduction in $\beta$-cell exocytosis [76]. A subsequent study using the SNX482 or genetic ablation of the $\mathrm{Ca}_{\mathrm{v}} 2.3$ subunit showed a strong reduction of second-phase insulin secretion without affecting the first one [86]. Thus, $\mathrm{Ca}_{\mathrm{v}} 2.3$ channels may be involved in controlling the replenishment of the releasable pool of vesicles via granule mobilization and/or priming of insulin-containing granules [50, 75].

Therefore, $\mathrm{Ca}_{\mathrm{v}} 1$ and $\mathrm{Ca}_{\mathrm{v}} 2$ represent almost the total $\beta$-cell current. Incubation with inhibitors isradipine (L-type) and SNX482 (R-type) blocked $80 \%$ of recording, and additional 
$\omega$-agatoxin IVA (P/Q-type) almost fully abolishes mouse $\beta$ cell current $[51,76]$.

As well proposed by Yang et al. (2014) [50] the localization and organization discrepancy between $\mathrm{Ca}_{\mathrm{v}} 1$ and $\mathrm{Ca}_{\mathrm{v}} 2$ channels may explain their phase-selective regulation in GIIS. Whilst $\mathrm{Ca}_{\mathrm{v}} 1$ channels are clustered and co-localized with fusion machinery to form exocytotic sites close to the plasma membrane (which enable fast exocytosis - first-phase insulin release), $\mathrm{Ca}_{\mathrm{v}} 2$ channels contribute to rising $\left[\mathrm{Ca}^{2+}\right]_{\mathrm{i}}$, leading to mobilization of new insulin-containing granules for $\beta$-cell late exocytosis (second phase) [52, 87, 88]. Moreover, it is speculated that $\mathrm{P} / \mathrm{Q}$-type $\mathrm{Ca}^{2+}$ channels may constitute functional complexes with secretory vesicles [84, 89].

The T-type $\mathrm{Ca}_{\mathrm{v}} 3$ channels are characterized by a tiny single-channel conductance and rapid inactivation, and become activated at membrane potentials above $-60 \mathrm{mV}$. These channels are associated with action potential firing, repetitive firing and may play a role in pacemaking in human $\beta$-cells $[52,73,84]$. These channels are recorded in human and rat $\beta$-cells $[52,75]$ and can be reversely blocked by NNC 553096 [72]. Due to the presence of the LVA T-type channels, together with low resting $\mathrm{K}_{\text {ATP }}$ channel activity, human $\beta$ cells are closer to the threshold for insulin secretion than those in mice, which may be explained by the higher sensitivity of GIIS seen in humans. Thus, small depolarizing currents may strongly induce electrical activity in human $\beta$-cells [52]. Interestingly, $\mathrm{Ca}_{\mathrm{v}} 3$ are absent in normal mouse $\beta$-cells, but expressed in NOD mouse (T1D animal model). This abnormal activity contributes to increased basal $\left[\mathrm{Ca}^{2+}\right]_{i}$, leading to apoptotic mechanisms $[90,91] . \mathrm{Ca}_{\mathrm{v}} 3.2$ channel seems to only contribute with $6 \%$ of the integrated whole-cell $\mathrm{Ca}_{\mathrm{v}}$ current in the human $\beta$-cell [50] and its role in insulin release needs to be more investigated.

The regulation of $\beta$-cell $\mathrm{Ca}_{\mathrm{v}}$ channels underlies a variety of mechanisms that modulate channel conductivity and/or density $[50,73]$. For example, activation of membrane receptors, including $G$ protein-coupled receptors, increases GIIS due to upregulation of $\mathrm{Ca}_{\mathrm{v}}$ channels activity via protein kinases and second messengers $[51,73]$. The calcium/calmodulin-dependent kinase II (CaMKII) directly interacts with Cav2.1 channels to increases their activity [92]. $\mathrm{Ca}_{\mathrm{v}}$ channels can also respond differently to glucose metabolism-derived signals, such as inositol hexakisphosphate, which enhances channel activity via activation of adenylyl cyclase-PKA cascade [93]. Moreover, increased cholesterol impaired glucose-evoked mitochondrial ATP production, leading to a smaller glucose-induced depolarization, and reducing $\mathrm{Ca}_{\mathrm{v}}$ density in the plasma membrane [94].

In addition to $\mathrm{Ca}^{2+}$ permeability, $\mathrm{Ca}_{\mathrm{v}}$ channel can operate as a signaling membrane receptor to mediate insulin secretion prior to transporting $\mathrm{Ca}^{2+}$ into the cell $[80,95]$. Given that other cations, such as $\mathrm{Ba}^{2+}, \mathrm{Cs}^{3+}$ and $\mathrm{La}^{3+}$ can bind to $\mathrm{Ca}^{2+}$-binding site EEEE, various studies have replaced $\mathrm{Ca}^{2+}$ with the mentioned ions to evaluate the $\mathrm{Ca}_{\mathrm{v}}$ signal transduction via $\mathrm{Ca}^{2+}$-independent insulin release [50, 96, 97]. For example, the conformational change of the Cav1.2 subunit following depolarization - in cooperation with voltage perturbation and $\mathrm{Ca}^{2+}$ binding at the open pore of the channel- leads to insulin secretion by exocytotic machinery prior to $\mathrm{Ca}^{2+}$ influx [79, 80].

\section{CONCLUSION AND PERSPECTIVES TO THE NEAR FUTURE}

The regulated insulin secretion and the glycaemia homeostasis still represent the main focus for T2D treatment. In addition, the replenishment of glibenclamide for new compounds in antidiabetic therapy is needed. Besides chronic hyperglycemia, $\beta$-cell hyperplasia and exhaustion are commonly observed in patients undergoing treatment with this drug [21].

Glibenclamide derivatives have shown great responses for these requirements: decreased serum glucose levels after an oral and acute treatment and their insulinogenic index points the preferential one as being insulin secretagogue. In this way, some of these derivatives promise in the near future to efficiently and safely replace glibenclamide as a hypoglycemic drug to be used on the treatment of T2D. As discussed above, some compounds are able to follow the pathway triggered by high glucose to induce insulin secretion, however presenting high insulinogenic index. In contrast, other compounds directly close the $\mathrm{K}_{\mathrm{ATP}}$ channels causing $\beta$-cell excitability that leads to high $\mathrm{Ca}^{2+}$ and insulin secretion. These ones show high potential insulin secretagogue, endue insulinomimetic action and exhibit median insulinogenic index (between glibenclamide and glucose). Therefore, suitable for diabetes therapy, since insulin secretion remains for a long period and does not seem to deplete pancreatic $\beta$-cells.

Once the role of the different types of $\mathrm{Ca}_{\mathrm{v}}$ channels in the regulation of insulin release is elucidated, new strategies may be addressed to enhance the signal transduction stimulated by these glibenclamide-based molecules. The L-type $\mathrm{Ca}_{\mathrm{v}}$ channels are important targets due to both association with exocytotic proteins and involvement with the majority of the $\mathrm{Ca}^{2+}$ influx in $\beta$-cells, primarily in the first-phase of insulin release, which is clearly impaired in T2D patients. In addition, the $\mathrm{P} / \mathrm{Q}$-type $\mathrm{Ca}_{\mathrm{v}}$ channels are also a key component in granules release as they are activated during the peak of the action potential and trigger the signal for insulin-containing vesicle exocytosis. Thus, they represent potential targets for treating impaired insulin secretion by glibenclamide analogues/derivatives.

Given that CFTR and $\mathrm{ClC}_{3}$ are linked to insulin secretion [98-101] and can be blocked by glibenclamide, at least in extrapancreatic tissues $[102,103]$, it should be interesting to study if these channels are modulated by glibenclamide derivatives in the $\beta$-cell.

In summary, the selectivity of novel glibenclamide-based compounds promises greater efficiency and safety to restore glucose homeostasis by focusing their action on $\mathrm{K}_{\mathrm{ATP}}$ and calcium channels to stimulate insulin secretion in a nonabrupt, constant and lasting mechanism, and protecting $\beta$ cells from hyper excitability, dysfunction and cell death.

\section{CONFLICT OF INTEREST}

The authors confirm that this article content has no conflict of interest. 


\section{ACKNOWLEDGEMENTS}

The studies carried out in the authors' laboratory were supported by Conselho Nacional de Desenvolvimento e Tecnológico (CNPq/Grant\# 303753/2012-9; 472071/2013-0; 400109/2014-0), Coordenação de Pessoal de Nível Superior (CAPES), CAPES/COFECUB (Grant\# 554/07 and 133/07), Fundação de Amparo à Pesquisa do Estado de Santa Catarina (Grant\# 745/000) and Financiadora de Estudo e Projetos (FINEP/NUBIOCEL/Proinfra/150-2009).

\section{AUTHORS' CONTRIBUTIONS}

Marisa Jádna Silva Frederico - Organized the data of biological studies and selected derivatives as potential targets on ionic channels in pancreatic islets for insulin secretion.

Allisson Jhonatan Gomes Castro - Extensively worked on computer modeling for organizing the hypothesis of signal transduction summarized in schematic drawings for each derivative.

Danusa Menegaz - Collaborated with the discussion and critical analysis of the calcium and potassium channels and the physiological role on derivatives action to ameliorate glycaemia; also contributed for the manuscript organization.

Cahuê De Bernardis Murat - Selected references according to the role of each derivative, did the critical analysis of ionic channels, the general organization of the manuscript and worked extensively on the final edition.

Camila Pires Mendes - Contributed to the manuscript organization, updated the references and participated in the critical analysis of the general content of the manuscript.

Alessandra Mascarello - Synthesized, characterized the compounds and organized the text's chemical section; did the schematic drawing of (Schemes 1 and 2).

Ricardo José Nunes - Coordinated the strategic synthesis of compounds and contributed critically for the final version of the manuscript.

Fátima Regina Mena Barreto Silva - Collaborated on the first draft of the manuscript, did the critical analysis and correction of the last version; coordinated the final edition of the text and figures.

\section{REFERENCES}

[1] Cazarolli LH, Zanatta L, Alberton EH, et al. Flavonoids: cellular and molecular mechanism of action in glucose homeostasis. Mini Rev Med Chem 2008; 8: 1032-8.

[2] Cazarolli LH, Folador P, Moresco HH, Brighente IM, Pizzolatti MG, Silva FR. Mechanism of action of the stimulatory effect of apigenin6-C-(2"-O-alpha-1-rhamnopyranosyl)-beta-L-fucopyranoside on 14Cglucose uptake. Chem Biol Interact 2009; 179: 407-12.

[3] Donato J. The central nervous system as a promising target to treat diabetes mellitus. Curr Top Med Chem 2012; 12: 2070-81.

[4] Rodriguez-Diaz R, Menegaz D, Caicedo A. Neurotransmitters act as paracrine signals to regulate insulin secretion from the human pancreatic islet. J Physiol London 2014; 592: 3413-7.

[5] Silva FRMB, Frederico MJS, Castro AJG, da Luz G, Altenhofen D, Cazarolli LH. Glucose uptake: knowledge from in vivo, in situ and in vitro studies and health implications. In Glucose uptake: regulation, signaling pathways and health implications. Volume 1. 1st edition. Edited by Johnson CC, Williams DB. New York: Nova Science Publisher, Inc.; 2013: 45-76: Endocrinology Research and Clinical Developments]
[6] Maggs D, MacDonald I, Nauck MA. Glucose homeostasis and the gastrointestinal tract: insights into the treatment of diabetes. Diabetes Obes Metabol 2008; 10: 18-33.

[7] Wasserman DH. Four grams of glucose. Am J Physiol Endocrinol Metab 2009; 296: E11-E21.

[8] Komatsu M, Takei M, Ishii H, Sato Y. Glucose-stimulated insulin secretion: A newer perspective. J Diabetes Investig 2013; 4: 511-6.

[9] Tuomi T, Santoro N, Caprio S, Cai M, Weng J, Groop L. The many faces of diabetes: a disease with increasing heterogeneity. Lancet 2014; 383: 1084-94

[10] Alberti KG, Zimmet PZ. Diabetes: a look to the future. Lancet Diabetes Endocrinol 2014; 2: e1-2.

[11] Zung A, Glaser B, Nimri R, Zadik Z. Glibenclamide treatment in permanent neonatal diabetes mellitus due to an activating mutation in Kir6.2. J Clin Endocrinol Metab 2004, 89: 5504-7.

[12] Froguel P, Velho G: Genetic determinants of type 2 diabetes. Recent Prog Horm Res 2001; 56: 91-105.

[13] Murphy R, Ellard S, Hattersley AT. Clinical implications of a molecular genetic classification of monogenic beta-cell diabetes. Nat Clin Pract Endocrinol Metab 2008, 4: 200-213.

[14] Lyssenko V, Jonsson A, Almgren P, et al. Clinical risk factors, DNA variants, and the development of type 2 diabetes. N Engl J Med 2008; 359: 2220-32.

[15] Kumar H, Mishra M, Bajpai S, et al. Correlation of insulin resistance, beta cell function and insulin sensitivity with serum sFas and sFasL in newly diagnosed type 2 diabetes. Acta Diabetol 2013; 50: 511-8.

[16] Boden G. Obesity, insulin resistance and free fatty acids. Curr Opin Endocrinol Diabetes Obes 2011; 18: 139-43.

[17] Nichols CG, Remedi MS. The diabetic beta-cell: hyperstimulated vs. hyperexcited. Diabetes Obes Metab 2012; 14 (Suppl 3): 129-35.

[18] Henquin JC: Pathways in beta-cell stimulus-secretion coupling as targets for therapeutic insulin secretagogues. Diabetes 2004; 53 (Suppl 3): S48-58.

[19] Duhault J, Lavielle R: History and evolution of the concept of oral therapy in diabetes. Diabetes Res Clin Pract 1991; 14 (Suppl 2): S9-13.

[20] Hanefeld M, Patwardhan R, Jones NP. A one-year study comparing the efficacy and safety of rosiglitazone and glibenclamide in the treatment of type 2 diabetes. Nutr Metab Cardiovasc Dis 2007; 17: 13-23.

[21] Thule PM, Umpierrez G: Sulfonylureas: a new look at old therapy. Curr Diab Rep 2014; 14: 473.

[22] WHO Model Lists of Essential Medicines Available at: [http://www.who.int/medicines/publications/essentialmedicines/en/]

[23] Derosa G, Salvadeo SA, D'Angelo A, et al. Metabolic effect of repaglinide or acarbose when added to a double oral antidiabetic treatment with sulphonylureas and metformin: a double-blind, cross-over, clinical trial. Curr Med Res Opin 2009; 25: 607-15.

[24] Seino S, Takahashi H, Takahashi T, Shibasaki T. Treating diabetes today: a matter of selectivity of sulphonylureas. Diabetes Obes Metab 2012; 14 (Suppl 1): 9-13.

[25] Vilsboll T, Knop FK: Review: DDP IV inhibitors - current evidence and future directions. Br J Diabetes Vasc Dis 2007; 7: 69 74.

[26] Feldman JM. Glyburide: a second-generation sulfonylurea hypoglycemic agent. History, chemistry, metabolism, pharmacokinetics, clinical use and adverse effects. Pharmacotherapy 1985; 5: 43-62.

[27] Lebovitz HE, Feinglos MN. Mechanism of action of the secondgeneration sulfonylurea glipizide. Am J Med 1983; 75: 46-54.

[28] Basit A, Riaz M, Fawwad A. Glimepiride: evidence-based facts, trends, and observations (GIFTS). [corrected]. Vasc Health Risk Manag 2012; 8: 463-72.

[29] Russ U, Lange U, Loffler-Walz C, Hambrock A, Quast U. Interaction of the sulfonylthiourea HMR 1833 with sulfonylurea receptors and recombinant ATP-sensitive $\mathrm{K}(+)$ channels: comparison with glibenclamide. J Pharmacol Exp Ther 2001; 299: 1049-55.

[30] Yuriev E, Kong DC, Iskander MN. Investigation of structureactivity relationships in a series of glibenclamide analogues. Eur $\mathrm{J}$ Med Chem 2004; 39: 835-47.

[31] Schneider S, Ueberberg S, Korobeynikov A, et al. Synthesis and evaluation of a glibenclamide glucose-conjugate: a potential new lead compound for substituted glibenclamide derivatives as islet imaging agents. Regul Pept 2007; 139: 122-7. 
[32] Zhang HB, Zhang YA, Wu GZ, Zhou JP, Huang WL, Hu XW. Synthesis and biological evaluation of sulfonylurea and thiourea derivatives substituted with benzenesulfonamide groups as potential hypoglycemic agents. Bioorg Med Chem Lett 2009; 19: 17404.

[33] Calderone V, Rapposelli S, Martelli A, et al. NO-glibenclamide derivatives: prototypes of a new class of nitric oxide-releasing antidiabetic drugs. Bioorg Med Chem 2009; 17: 5426-32.

[34] Figueroa-Valverde L, Diaz-Cedillo F, Garcia-Cervera A. Synthesis of Glibenclamide-pregnenolone conjugate and its relationship with physicochemical descriptors $\log \mathrm{P}, \mathrm{Rm}, \mathrm{Vm}, \mathrm{Pc}$ and St. Asian J Chem 2011; 23: 3999-4002.

[35] Mascarello A, Silva Frederico MJ, Gomes Castro AJ. Novel sulfonyl(thio)urea derivatives act efficiently both as insulin secretagogues and as insulinomimetic compounds. Eur J Med Chem 2014; 86: 491-501.

[36] Frederico MJS, Mascarello A, Castro AJG, et al. Antidiabetic effects of sulfonamide derivatives based on structural fragment of sulphonylureas. Curr Trend Med Chem 2013; 7: 11-25.

[37] Frederico MJ, Castro AJ, Mascarello A, et al. Acylhydrazones contribute to serum glucose homeostasis through dual physiological targets. Curr Top Med Chem 2012; 12: 2049-58.

[38] Alberton EH, Damazio RG, Cazarolli LH, et al. Influence of chalcone analogues on serum glucose levels in hyperglycemic rats. Chem Biol Interact 2008; 171: 355-362.

[39] Damazio RG, Zanatta AP, Cazarolli LH, et al. Nitrochalcones: potential in vivo insulin secretagogues. Biochimie 2009; 91: 14938.

[40] Damazio RG, Zanatta AP, Cazarolli LH, et al. Antihyperglycemic activity of naphthylchalcones. Eur J Med Chem 2010; 45: 1332-7.

[41] Babes A, Fischer MJ, Filipovic M, et al. The anti-diabetic drug glibenclamide is an agonist of the transient receptor potential Ankyrin 1 (TRPA1) ion channel. Eur J Pharmacol 2013; 704: 15-22.

[42] Maedler K, Carr RD, Bosco D, Zuellig RA, Berney T, Donath MY. Sulfonylurea induced beta-cell apoptosis in cultured human islets. J Clin Endocrinol Metab 2005; 90: 501-6.

[43] Sawada F, Inoguchi T, Tsubouchi H, et al. Differential effect of sulfonylureas on production of reactive oxygen species and apoptosis in cultured pancreatic beta-cell line, MIN6. Metabolism 2008; 57: 1038-45.

[44] Diaz-Garcia CM. The TRPA1 channel and oral hypoglycemic agents: is there complicity in $\beta$-cell exhaustion? Channels (Austin) 2013; 7: 420-2.

[45] Confederat L, Constantin S, Lupaşcu F, Pânzariu A, Hăncianu M, Profire L. Hypoglycemia Induced By Antidiabetic Sulfonylureas. Rev Med Chir Soc Med Nat Iasi 2015; 119: 579-84.

[46] Vinzio S, Andrès E, Perrin AE, Schlienger JL, Goichot B. Glibenclamide-induced acute haemolytic anaemia revealing a G6PDdeficiency. Diabetes Res Clin Pract 2004; 64: 181-3.

[47] Rawson NS, Harding SR, Malcolm E, Lueck L. Hospitalizations for aplastic anemia and agranulocytosis in Saskatchewan: incidence and associations with antecedent prescription drug use. J Clin Epidemiol 1998; 51: 1343-55.

[48] Juurlink DN, Gomes T, Shah BR, Mamdani MM. Adverse cardiovascular events during treatment with glyburide (glibenclamide) or gliclazide in a high-risk population. Diabet Med 2012; 29: 1524-8.

[49] Kefaloyianni E, Lyssand JS, Moreno C, et al. Comparative proteomic analysis of the ATP-sensitive $\mathrm{K}+$ channel complex in different tissue types. Proteomics 2013; 13: 368-78.

[50] Yang SN, Shi Y, Yang G, Li Y, Yu J, Berggren PO. Ionic mechanisms in pancreatic beta cell signaling. Cell Mol Life Sci 2014; 71: 4149-77.

[51] Yang SN, Berggren PO. The role of voltage-gated calcium channels in pancreatic beta-cell physiology and pathophysiology. Endocr Rev 2006; 27: 621-76.

[52] Rorsman P, Braun M. Regulation of insulin secretion in human pancreatic islets. Annu Rev Physiol 2013; 75: 155-179.

[53] Nichols CG. KATP channels as molecular sensors of cellular metabolism. Nature 2006; 440: 470-6.

[54] Gribble FM, Reimann F. Sulphonylurea action revisited: the postcloning era. Diabetologia 2003; 46: 875-91.

[55] Gribble FM, Reimann F. Differential selectivity of insulin secretagogues: mechanisms, clinical implications, and drug interactions. J Diabetes Complicat 2003; 17: 11-5.
[56] Gribble FM, Tucker SJ, Haug T, Ashcroft FM. MgATP activates the beta cell KATP channel by interaction with its SUR1 subunit. Proc Natl Acad Sci USA 1998; 95: 7185-90.

[57] Ashcroft FM, Gribble FM: ATP-sensitive K+ channels and insulin secretion: their role in health and disease. Diabetologia 1999; 42: 903-19.

[58] Aguilar-Bryan L, Bryan J. Molecular biology of adenosine triphosphate-sensitive potassium channels. Endocr Rev 1999; 20: 101-35.

[59] Bao L, Kefaloyianni E, Lader J, et al. Unique properties of the ATP-sensitive $\mathrm{K}(+)$ channel in the mouse ventricular cardiac conduction system. Circ Arrhythm Electrophysiol 2011; 4: 926-35.

[60] Ashcroft FM, Gribble FM: Tissue-specific effects of sulfonylureas: lessons from studies of cloned K(ATP) channels. J Diabetes Complicat 2000; 14: 192-6.

[61] Proks P, Reimann F, Green N, Gribble F, Ashcroft F. Sulfonylurea stimulation of insulin secretion. Diabetes 2002; 51 (Suppl 3): S368376.

[62] Bryan J, Vila-Carriles WH, Zhao G, Babenko AP, Aguilar-Bryan L. Toward linking structure with function in ATP-sensitive $\mathrm{K}+$ channels. Diabetes 2004; 53 (Suppl 3): S104-12.

[63] Mendez CF, Leibiger IB, Leibiger B, et al. Rapid association of protein kinase $\mathrm{C}$-epsilon with insulin granules is essential for insulin exocytosis. J Biol Chem 2003; 278: 44753-7.

[64] Zhang CL, Katoh M, Shibasaki T, et al. The cAMP sensor Epac2 is a direct target of antidiabetic sulfonylurea drugs. Science 2009; 325: 607-10.

[65] Herbst KJ, Coltharp C, Amzel LM, Zhang J. Direct activation of Epac by sulfonylurea is isoform selective. Chem Biol 2011; 18: 243-51.

[66] Catterall WA. Voltage-gated calcium channels. Cold Spring Harb Perspect Biol 2011; 3: a003947.

[67] Berridge MJ, Lipp P, Bootman MD. The versatility and universality of calcium signalling. Nat Rev Mol Cell Biol 2000; 1: 11-21.

[68] Hofmann F, Flockerzi V, Kahl S, Wegener JW. L-type CaV1.2 calcium channels: from in vitro findings to in vivo function. Physiol Rev 2014; 94: 303-26.

[69] Moosmang S, Kleppisch T, Wegener J, Welling A, Hofmann F. Analysis of calcium channels by conditional mutagenesis. Handb Exp Pharmacol 2007: 469-90.

[70] Arikkath J, Campbell KP: Auxiliary subunits: essential components of the voltage-gated calcium channel complex. Curr Opin Neurobiol 2003; 13: 298-307.

[71] Ertel EA, Campbell KP, Harpold MM, et al. Nomenclature of voltage-gated calcium channels. Neuron 2000; 25: 533-5.

[72] Braun M, Ramracheya R, Bengtsson M, et al. Voltage-gated ion channels in human pancreatic beta-cells: electrophysiological characterization and role in insulin secretion. Diabetes 2008; 57 : 1618-28.

[73] Yang SN, Berggren PO: Beta-cell CaV channel regulation in physiology and pathophysiology. Am J Physiol Endocrinol Metab 2005; 288: E16-28.

[74] Drews G, Krippeit-Drews P, Dufer M. Electrophysiology of islet cells. Adv Exp Med Biol 2010; 654: 115-63.

[75] Rorsman P, Braun M, Zhang Q. Regulation of calcium in pancreatic alpha- and beta-cells in health and disease. Cell Calcium 2012; 51: 300-8.

[76] Schulla V, Renstrom E, Feil R, et al. Impaired insulin secretion and glucose tolerance in beta cell-selective $\mathrm{Ca}(\mathrm{v}) 1.2 \mathrm{Ca} 2+$ channel null mice. EMBO J 2003; 22: 3844-54.

[77] Rorsman P, Ramracheya R, Rorsman NJ, Zhang Q. ATP-regulated potassium channels and voltage-gated calcium channels in pancreatic alpha and beta cells: similar functions but reciprocal effects on secretion. Diabetologia 2014; 57: 1749-61.

[78] Stary A, Shafrir Y, Hering S, Wolschann P, Guy HR: Structural model of the Ca V 1.2 pore. Channels (Austin) 2008; 2: 210-5.

[79] Trus M, Corkey RF, Nesher R, et al. The L-type voltage-gated $\mathrm{Ca} 2+$ channel is the $\mathrm{Ca} 2+$ sensor protein of stimulus-secretion coupling in pancreatic beta cells. Biochemistry 2007; 46: 14461-7.

[80] Atlas D. Voltage-gated calcium channels function as $\mathrm{Ca} 2+-$ activated signaling receptors. Trends Biochem Sci 2014; 39: 45-52.

[81] Reinbothe TM, Alkayyali S, Ahlqvist E, et al. The human L-type calcium channel Cav1.3 regulates insulin release and polymorphisms in CACNA1D associate with type 2 diabetes. Diabetologia 2013; 56: 340-9. 
[82] Barg S, Ma X, Eliasson L, et al. Fast exocytosis with few $\mathrm{Ca}(2+)$ channels in insulin-secreting mouse pancreatic B cells. Biophys J 2001; 81: 3308-23.

[83] Namkung Y, Skrypnyk N, Jeong MJ, et al. Requirement for the Ltype $\mathrm{Ca}(2+)$ channel alpha(1D) subunit in postnatal pancreatic beta cell generation. J Clin Invest 2001; 108: 1015-22.

[84] Braun M. The alphabetadelta of ion channels in human islet cells. Islets 2009, 1: 160-2.

[85] Pereverzev A, Mikhna M, Vajna R, et al. Disturbances in glucosetolerance, insulin-release, and stress-induced hyperglycemia upon disruption of the $\mathrm{Ca}(\mathrm{v}) 2.3$ (alpha 1E) subunit of voltage-gated $\mathrm{Ca}(2+)$ channels. Mol Endocrinol 2002; 16: 884-95.

[86] Jing X, Li DQ, Olofsson CS, et al. CaV2.3 calcium channels control second-phase insulin release. J Clin Invest 2005; 115: 146-54.

[87] Henquin JC. Regulation of insulin secretion: a matter of phase control and amplitude modulation. Diabetologia 2009; 52: 73951

[88] Seino S: Cell signalling in insulin secretion: the molecular targets of ATP, cAMP and sulfonylurea. Diabetologia 2012; 55: 2096108.

[89] Barg S, Eliasson L, Renstrom E, Rorsman P. A subset of 50 secretory granules in close contact with L-type $\mathrm{Ca} 2+$ channels accounts for first-phase insulin secretion in mouse beta-cells. Diabetes 2002; 51 (Suppl 1): S74-82.

[90] Wang L, Bhattacharjee A, Fu J, Li M. Abnormally expressed lowvoltage-activated calcium channels in beta-cells from NOD mice and a related clonal cell line. Diabetes 1996; 45: 1678-83.

[91] Wang L, Bhattacharjee A, Zuo Z, et al. A low voltage-activated $\mathrm{Ca} 2+$ current mediates cytokine-induced pancreatic beta-cell death. Endocrinology 1999; 140: 1200-4.

[92] Jiang X, Lautermilch NJ, Watari H, Westenbroek RE, Scheuer T, Catterall WA. Modulation of CaV2.1 channels by $\mathrm{Ca} 2+$, calmodulin-dependent protein kinase II bound to the C-terminal domain. Proc Natl Acad Sci USA 2008; 105: 341-6.
[93] Yang SN, Yu J, Mayr GW, Hofmann F, Larsson O, Berggren PO. Inositol hexakisphosphate increases L-type $\mathrm{Ca} 2+$ channel activity by stimulation of adenylyl cyclase. FASEB J 2001; 15: 1753-63.

[94] Lee AK, Yeung-Yam-Wah V, Tse FW, Tse A. Cholesterol elevation impairs glucose-stimulated $\mathrm{Ca}(2+)$ signaling in mouse pancreatic beta-cells. Endocrinology 2011; 152: 3351-61.

[95] Hagalili Y, Bachnoff N, Atlas D. The voltage-gated $\mathrm{Ca}(2+)$ channel is the $\mathrm{Ca}(2+)$ sensor protein of secretion. Biochemistry 2008; 47 : 13822-30.

[96] Marom M, Sebag A, Atlas D. Cations residing at the selectivity filter of the voltage-gated $\mathrm{Ca} 2+$-channel modify fusion-pore kinetics. Channels (Austin) 2007; 1: 377-86.

[97] Lerner I, Trus M, Cohen R, Yizhar O, Nussinovitch I, Atlas D. Ion interaction at the pore of Lc-type $\mathrm{Ca} 2+$ channel is sufficient to mediate depolarization-induced exocytosis. J Neurochem 2006; 97 116-27.

[98] Bellin MD, Laguna $\mathrm{T}$, Leschyshyn $\mathrm{J}$ et al. A. Insulin secretion improves in cystic fibrosis following ivacaftor correction of CFTR: a small pilot study. Pediatric Diabetes 2013; 14: 417-21.

[99] Edlund A, Esguerra JL, Wendt A, Flodstrom-Tullberg M, Eliasson L. CFTR and Anoctamin 1 (ANO1) contribute to cAMP amplified exocytosis and insulin secretion in human and murine pancreatic beta-cells. BMC Med 2014; 12: 87.

[100] Deriy LV, Gomez EA, Jacobson DA, et al. The granular chloride channel ClC-3 is permissive for insulin secretion. Cell Metab 2009; 10: $316-23$.

[101] Li DQ, Jing X, Salehi A, et al. Suppression of sulfonylurea- and glucose-induced insulin secretion in vitro and in vivo in mice lacking the chloride transport protein ClC-3. Cell Metab 2009; 10: 30915 .

[102] Kominkova V, Ondrias K, Tomaskova Z. Inhibitory effect of glybenclamide on mitochondrial chloride channels from rat heart. Biochem Biophys Res Commun 2013; 434: 836-40.

[103] Cai Z, Li H, Chen JH, Sheppard DN. Acute inhibition of the cystic fibrosis transmembrane conductance regulator (CFTR) Cl- channel by thyroid hormones involves multiple mechanisms. Am J Physio Cell Physiol 2013; 305: C817-28. 